\author{
UNIVERSIDADE DE SÃO PAULO \\ FACULDADE DE FILOSOFIA, LETRAS E CIÊNCIAS HUMANAS \\ DEPARTAMENTO DE GEOGRAFIA \\ PROGRAMA DE PÓS-GRADUAÇÃO EM GEOGRAFIA HUMANA
}

\title{
O MOVIMENTO DE FUSÕES E AQUISIÇÕES DE EMPRESAS E O PROCESSO DE PRIVATIZAÇÃO E DESNACIONALIZAÇÃO NA DÉCADA DE 1990 - O CASO BRASILEIRO
}

Domingos Sávio Corrêa

Orientador: Prof. Dr. Armen Mamigonian

Dissertação de mestrado apresentada ao Programa de PósGraduação em Geografia Humana da Faculdade de Filosofia, Letras e Ciências Humanas da Universidade de São Paulo, para a obtenção do título de Mestre em Geografia Humana.

SÃO PAULO

2004 
UNIVERSIDADE DE SÃO PAULO

FACULDADE DE FILOSOFIA, LETRAS E CIÊNCIAS HUMANAS DEPARTAMENTO DE GEOGRAFIA

PROGRAMA DE PÓS-GRADUAÇÃO EM GEOGRAFIA HUMANA

O MOVIMENTO DE FUSÕES E AQUISIÇÕES DE EMPRESAS E O PROCESSO DE PRIVATIZAÇÃO E DESNACIONALIZAÇÃO NA DÉCADA DE 1990 - O CASO BRASILEIRO

Domingos Sávio Corrêa

SÃO PAULO

2004 


\section{DEDICATÓRIA}

Dedico este trabalho ao Professor Armen Mamigonian, a Marta da Silveira Luedemann e Anita Pedrosa Corrêa, pelo estímulo e compreensão com as escolhas do trabalho $e$ os caminhos percorridos .

À memória de Jayme Correia e Jayme Correia Filho. 


\section{AGRADECIMENTOS}

Muitas pessoas contribuíram nas diversas etapas deste trabalho, entretanto o apoio de algumas foi realmente inestimável:

Ao Prof. Armen Mamigonian, a quem devo o estímulo constante e a demonstração permanente do rumo a tomar em todas as fases do trabalho.

Ao Professor Pedro Paulo Perides, que contribuiu de maneira fundamental na realização deste trabalho.

- $\quad$ Aos Professores das disciplinas de pós-graduação: Armen Mamigonian, Sérgio Buarque de Hollanda Filho, Luiz Augusto de Queiroz Ablas, Osvaldo Coggiola e Milton Santos (in memoria).

- A Marta Luedemann, por seu constante incentivo, carinho e solidariedade.

- $\quad$ À minha família, pela força especial de minha mãe, Oremy Lima Correa, além de Cléia, Anita, Caio, Lorenzo e Júlia.

- A Da. Cecília da Silveira, pelo alento e hospitalidade.

- $\quad$ Ao Fernando e Cecília, pelo incentivo e apoio permanente, inclusive logístico.

- $\quad$ Aos amigos - Carlos Henrique (Caíca), Sérgio, Izildo, Wagner Lorence e Elias.

- $\quad$ Aos funcionários da Secretaria de Assistência Social da PMSP - especialmente Viviane, Elinea, Maria Cecília, Ana e João.

- Aos funcionários da Secretaria de Pós-Graduação: Ana, Jurema, Rosângela e Cida (e ao Orlando); ao pessoal da Seção de Administração da FFLCH e das Bibliotecas (Geografia e FEA), fundamentais no desenvolvimento de todas as pesquisas.

- $\quad$ Aos funcionários do Arquivo do Estado de São Paulo.

- A Silvia Lobo, pelo apoio e acompanhamento de todo o processo.

Ao CNPq, pelo apoio financeiro concedido através de Bolsa de Estudos.

A todos, os meus sinceros agradecimentos. 


\section{RESUMO}

Esta pesquisa analisa o processo de concentração de capital, através de fusões e aquisições de empresas privadas e públicas no Brasil, nos anos 90, devido as políticas neoliberais adotadas pelos governos Collor de Mello e Fernando Henrique. Nos anos 90, os programas neoliberais difundidos na América Latina, foram delimitados pelo Consenso de Washington e formalizados nos acordos entre o FMI e o Banco Mundial com os governos latino americanos.

As orientações visavam a estabilização das economias dos "países emergentes", a contenção de gastos e investimentos Estatais, restrição do papel do Estado, com a privatização de empresas, bancos, recursos minerais e energéticos, etc. Assim, a abertura comercial e as reformas econômicas promovidas no Brasil, com aumento da participação dos investimentos externos deflagraram fusões e aquisições entre empresas nacionais (chamadas transações domésticas), e transações realizadas por empresas estrangeiras (denominadas cross border). A participação de empresas estrangeiras superou o volume de negócios entre empresas nacionais em quantidade, volume e valores, causando debates sobre a desnacionalização da economia brasileira.

Esta pesquisa analisa a concentração de capitais no movimento de fusões e aquisições das empresas brasileiras, avaliando os setores mais afetados e a formação de oligopólios, e as circunstâncias em que ocorreram essas transações no território nacional.

\section{PALAVRAS-CHAVE}

Fusões, aquisições, privatizações, concentração, desnacionalização. 


\begin{abstract}
This research analyzes the process of capital concentration, through merger and acquisitions of private companies and public in Brazil, in years 90, had the "neoliberal" politics adopted by the governments Collor de Mello and Fernando Henrique.

In years 90, the spread out "neoliberal" programs in Latin America, they had been delimited by the Consensus of Washington and legalized in the agreements between the FMI and the World Bank with the Latin American governments.

The instructions aimed at the stabilization of the economies of the "emergent countries", the State containment of expenses and investments, restriction of the paper of the State, with the privatization of companies, mineral and energy banks, resources, etc. Thus, the commercial opening and the promoted economic reforms in Brazil, with increase of the participation of the external investments motivate merger and acquisitions between national companies (called domestic transactions), and transactions carried through for foreign companies (called cross border). The participation of business-oriented foreign companies surpassed the volume between national companies in amount, volume and values, causing debates on the denationalization of the Brazilian economy.

This research analyzes the concentration of capitals in the movement of merger and acquisitions of the Brazilian companies, evaluating the sectors more affected and the formation of oligopolies, and the circumstances where these transactions in the domestic territory had occurred.
\end{abstract}

\title{
KEY WORDS
}

Mergers, acquisitions, privatizations, concentration, denationalization. 


\section{SUMÁRIO}

Resumo

Abstract

Índice de Tabelas

Índice de Gráficos

INTRODUÇÃO

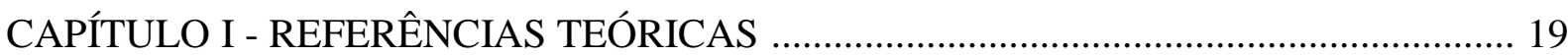

I.1 Fundamentos teóricos da acumulação do capital ........................................................... 19

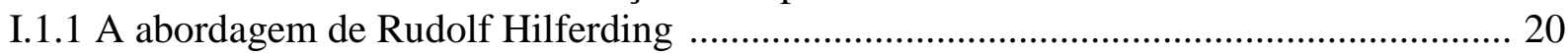

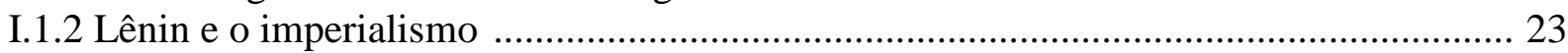

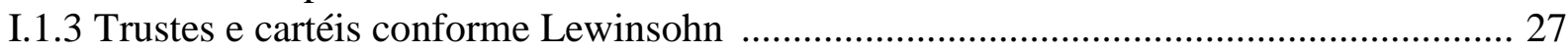

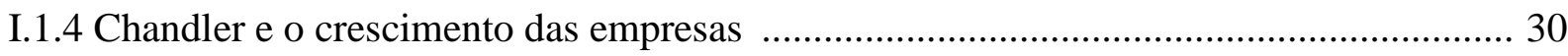

I.2 Abordagens recentes sobre o período ........................................................................ 33

I.3 Tipologia e causas do recente movimento internacional de fusões e aquisições ................36

I.4. A "globalização" e o movimento de fusões e aquisições .................................................. 39

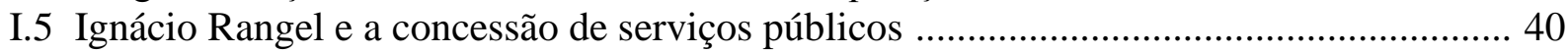

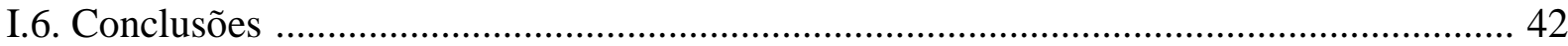

CAPÍTULO II - AS TRANSAÇÕES DOS ANOS 1990 E AS PRIVATIZAÇÕES NO CHILE, ARGENTINA E MÉXICO ...................................................................................... 44

II.1. Precedentes históricos do modelo de privatizações e de reformas econômicas ...............44

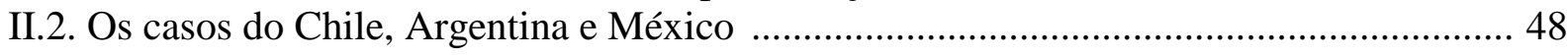

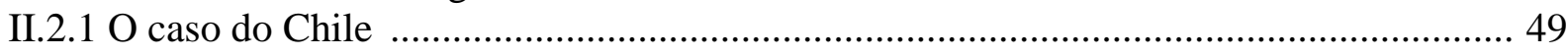

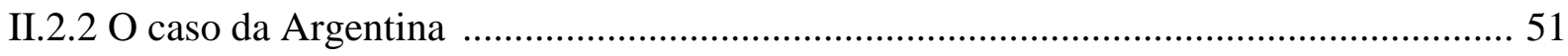

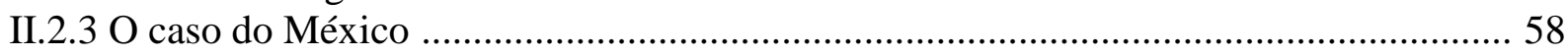

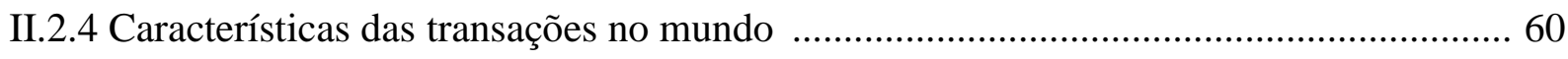

II.2.4.1 Possíveis contraposições ao movimento de fusões e aquisições .............................. 61

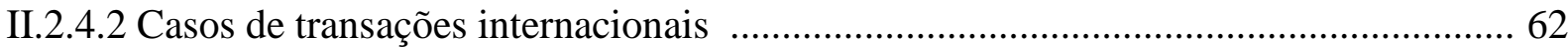

II.2.5 Investimentos estrangeiros diretos (IEDs) na América Latina ................................... 70

II.2.6 Internacionalização de empresas da América Latina .............................................. 72

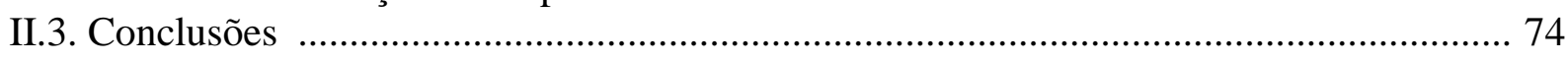

CAPÍTULO III - FUSÕES, AQUISIÇÕES E PRIVATIZAÇÕES NO BRASIL ................ 77

III.1. Breve histórico de fusões e aquisições anteriores à década de 1990 ............................. 77

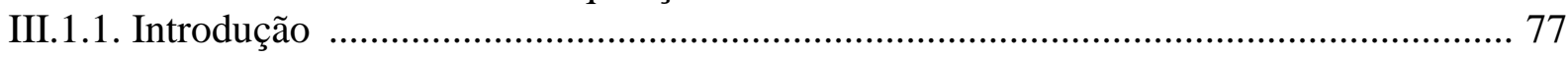

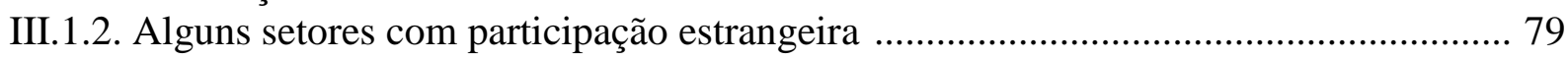



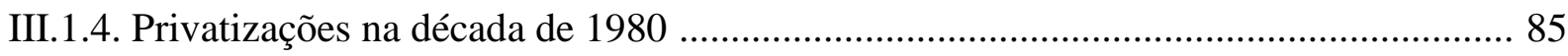

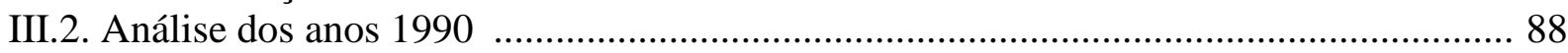

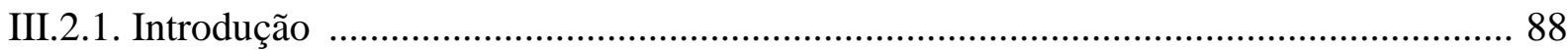

III.2.2 Causas das fusões e aquisições e intensificação dos Investimentos Estrangeiros ....... 90

III.2.3. Transações dos anos 1990 - pesquisas e análises de consultorias ............................. 96

III.2.4. Comparação de transações realizadas no Brasil ...................................................... 100

III.2.5. O setor de alimentos - líder em número de transações na década ............................. 103 


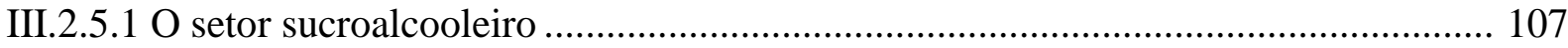

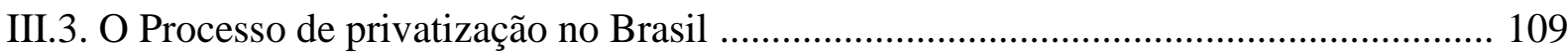

III.3.1 A privatização de setores estratégicos ................................................................ 110

III.3.1.1 A privatização do setor de transportes e portuário............................................... 111

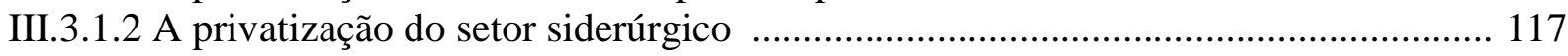

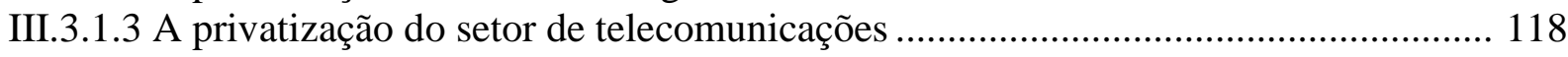

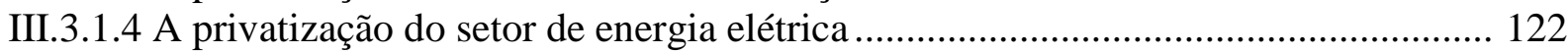

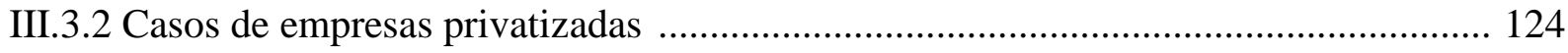

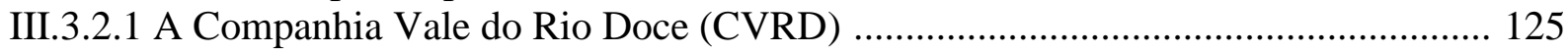

III.3.2.2 A Embraer - Empresa Brasileira de Aeronáutica S.A. .......................................... 130

III.4. Empresas brasileiras frente ao movimento de fusões e aquisições ............................ 132

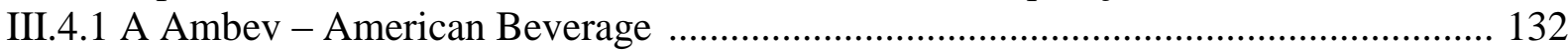

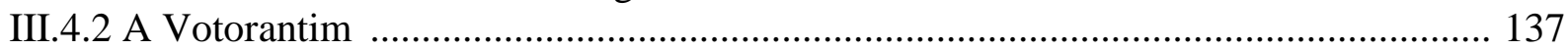

III.4.3 A Construtora Norberto Odebrecht ................................................................... 139

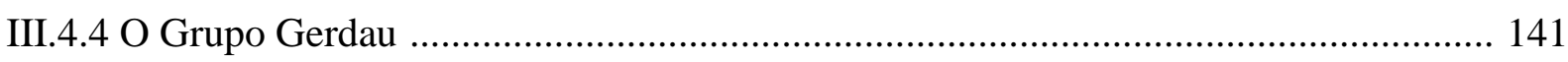

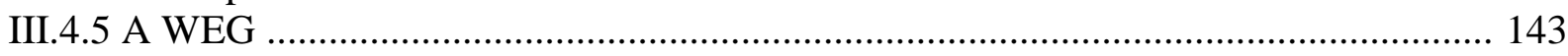

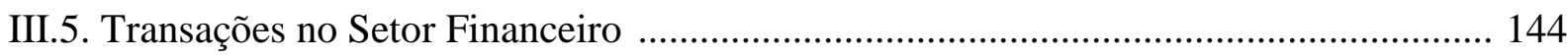

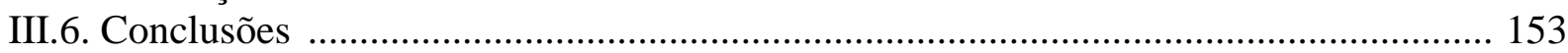

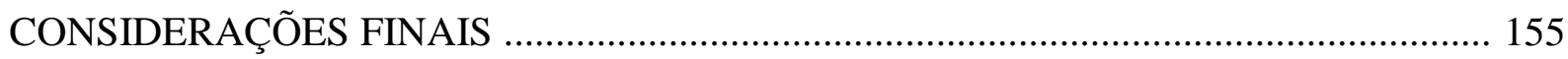



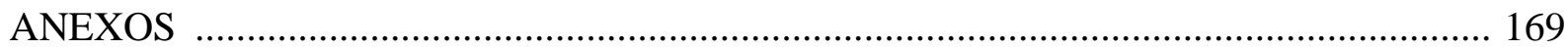




\section{Lista de Tabelas}

Tabela II.1 Número de fusões e aquisições nos países do Mercosul entre 1992 e 1998 ........ 55

Tabela II.2 Privatizações na Argentina, 1990 a Junho/1998, Número de Transações por Setor

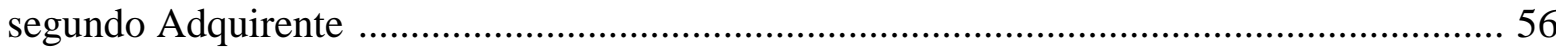

Tabela II.3 Estrutura das inversões diretas na Argentina por origem de capital e tipo de operação

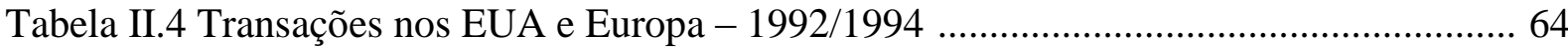

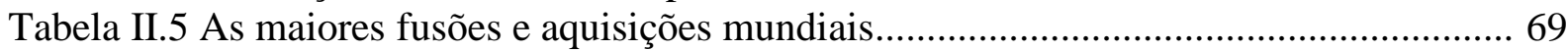

Tabela II.6 Maiores transações mundiais de fusões e aquisições em 1999 ........................... 70

Tabela II.7 Acervo de IEDs dos EUA na América Latina, por setores - 1990-1997 .............. 71

Tabela III.1 Indicadores de concentração nacional: 1940-1947 ....................................... 78

Tabela III.2 Casos de aquisições no setor automobilístico - década de 1960 ...................... 82

Tabela III.3 Outras firmas adquiridas na década de 1960 ................................................. 83

Tabela III.4 Número de transações e porcentagem segundo o tipo de comprador, 1990-1999 94

Tabela III.5 Total de Transações (domésticas e participação estrangeira) ............................. 97

Tabela III.6 Fusões e aquisições no Brasil - 1990-1999 ...................................................... 99

Tabela III.7 Comparação entre fontes sobre fusões e aquisições no Brasil ......................... 100

Tabela III.8 Comparação anual de fusões e aquisições por setores no Brasil

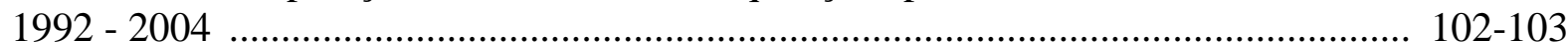

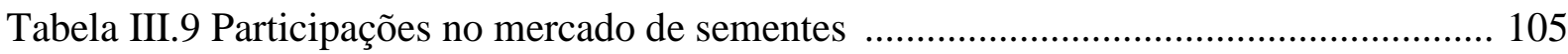

Tabela III.10 Transações - Setor Sucroalcooleiro: 1998 - $1^{\circ}$ trimestre/2003 ........................ 108

Tabela III.11 Malha Ferroviária Brasileira - 1993 .............................................................. 111

Tabela III.12 Estrutura do Capital após Leilão de Arrendamento / Concessão .................... 112

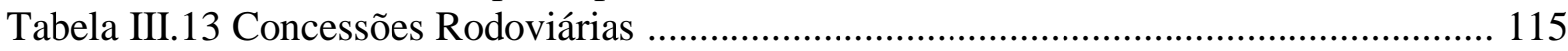

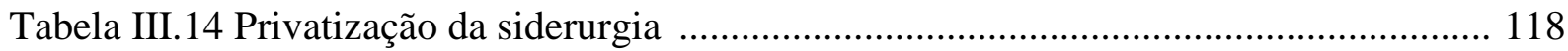

Tabela III.15: Privatização das Telecomunicações - 1998 .................................................. 119

Tabela III.16 Negócios com participação da CVRD (a partir de 2000) ....................... 128-130

Tabela III.17 Participação das 500 maiores empresas latino-americanas............................. 144

Tabela III.18 Fusões e aquisições bancárias ........................................................... 145-146

Tabela III.19: Outros Bancos Privatizados (valores em R\$) .............................................. 146

Tabela III.20: Crescimento da participação da banca estrangeira nos ativos totais dos sistemas

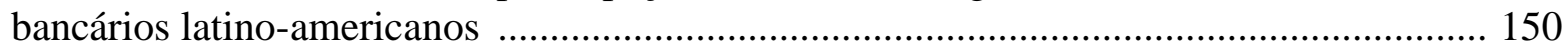

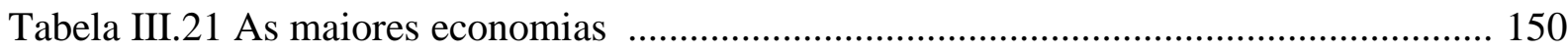

Tabela III.22 Ranking dos 15 maiores bancos do mundo ............................................... 151

Tabela III.23 Participação dos 20 Maiores Bancos ........................................................... 152 


\section{Lista de Gráficos}

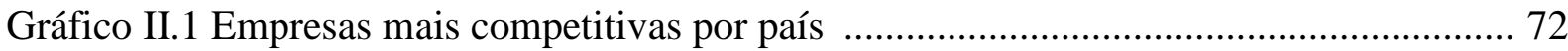

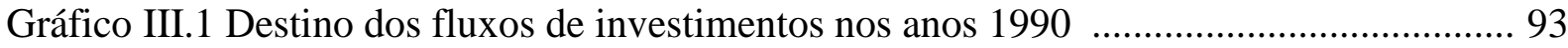

Gráfico III.2 Transações realizadas no Brasil (\%) - 1992-2004 ......................................... 95

Gráfico III.3 Transações Domésticas e com Participação Estrangeira .................................... 98

\section{Lista de Mapas}

Mapa II.1 América Latina - Distribuição das 100 empresas mais competitivas 73

Mapa III.1 Divisão regional das principais empresas de telecomunicações - 2003 121

Mapa III.2 Banco Santander Central Hispano e Banco Bilbao Viscaya: Presença na América Latina 1999 149 
"Administrar a crise" parece ser a palavra de ordem nos arraiais da direita governista (o que sempre dá para entender) como nos meios informados da esquerda oposicionista (o que, pelo menos, deve causar surpresa). Por outras palavras, não se cogita de combater a crise, de superá-la, de sair dela, mas de conviver com ela, dividindo "equitativamente" seus efeitos. A diferença entre direitistas e esquerdistas parece limitar-se ao que se deve entender por equitativo, isto é, se o peso maior da crise deve cair sobre os ombros dos assalariados ou sobre os do grande patronato - com as multinacionais à frente.

Ignácio Rangel, 1983

A inflação tem sido escolhida pelos neoliberais do mundo inteiro como o inimigo público número um, mas os estudiosos de esquerda devem eleger a crise econômica como a questão fundamental, já que a inflação é conseqüência da crise, um epifenômeno. Procurar remédios para a inflação é no mínimo um equívoco, quando se devem buscar os caminhos para a saída da crise, no interesse dos trabalhadores e da nação.

Armen Mamigonian, 1999 


\section{INTRODUÇÃO}

O movimento de fusões e aquisições de empresas, associado ao processo de desnacionalização e privatização, marcou a década de 1990 no Brasil - através das reformas e desregulamentações executadas pelos governos neoliberais, em conformidade com as determinações e acordos realizados com o Fundo Monetário Internacional e outras instituições financeiras internacionais ${ }^{12}$.

As transações entre empresas, principalmente através de aquisições, privatizações e fusões, repercutiram na economia desde meados dos anos 1990, no Brasil, quando ocorreram os primeiros negócios. Primeiramente através da venda de empresas privadas brasileiras, e em seguida como o resultado de discussões no âmbito do governo, que culminaram com o Plano Nacional de Desestatização e o conseqüente processo de privatização. Talvez o primeiro negócio fechado no país em 1990, tenha sido a aquisição do setor de catering (cozinha industrial) da Wells (grupo ASD, pertencente a Alcides Diniz), pela International Service System (ISS), por US\$ 13 milhões. A entrada da ISS no setor de alimentação obedeceria a estratégia da empresa de ampliar o setor de prestação de serviços. Em seu planejamento de longo prazo, o grupo estaria pensando na privatização e internacionalização que viria a atingir o país a partir de então. O grupo ISS surgiu na Dinamarca em 1901. ${ }^{3}$

No início de 1990 também ocorreu a compra da fábrica Bangu, antiga "Progresso Industrial do Brasil”, uma tecelagem fundada em 1889, para o Grupo Dona Isabel, pertencente a Ricardo Haddad, que planejava modernizar a empresa. ${ }^{4}$

$\mathrm{O}$ crescimento dessas transações no país foi intenso e redimensionou $\mathrm{o}$ posicionamento e a atuação das empresas no território nacional, tanto dos grandes grupos estrangeiros como das empresas de capital nacional, cuja participação no mercado doméstico diminuiu em termos relativos.

\footnotetext{
${ }^{1}$ No início da década de 1990, o Bird sugeria mudanças no projeto de privatização em discussão no âmbito do governo Collor, no sentido de abrir as privatizações à participação de investidores externos $(\mathrm{O}$ Estado de $\mathrm{S}$. Paulo, 10/03/1990), o que terminou ocorrendo em larga escala nas privatizações do governo Fernando Henrique. ${ }^{2}$ Em 1998, por exemplo, o ministro da Fazenda (Pedro Malan) ao discutir com o presidente do BNDES (André Lara Resende), os termos de um discurso da campanha de reeleição de Fernando Henrique, revelou o interesse do FMI em saber o teor do discurso antes da sua divulgação (Folha de S. Paulo, 27/05/1999).

${ }^{3}$ O Estado de São Paulo, 09/01/1990, p. 12.

${ }^{4}$ O Estado de São Paulo, 21/01/1990, p. 11.
} 
Para viabilizar e justificar o processo de desestatização, difundiu-se na sociedade a idéia (neoliberal) de que as empresas estatais seriam ineficientes, dispendiosas e serviriam apenas a propósitos políticos, através do loteamento de cargos e empreguismo desenfreado. A Siderúrgica Usiminas, por exemplo, primeira empresa a ser privatizada (24/10/1991) no governo Fernando Collor de Melo, além de ser uma estatal estratégica, era também superavitária e profissionalmente administrada.

Assim, deve-se ressaltar o descompasso entre a liberalização implementada pelo governo, desde a gestão de Fernando Collor, e a realidade das empresas no início da década, pois muitas delas, além de estratégicas para o desenvolvimento do país, também eram lucrativas - como os setores de mineração, financeiro, de telecomunicações, químico, petroquímico, siderúrgico - e a necessidade da sua privatização, portanto, seria questionável. Assim, o modelo de privatização implantado no país caracterizou-se pela transferência do patrimônio público ao setor privado, sobretudo ao capital estrangeiro. Houve, inclusive, o fechamento da Bolsa de Valores do Rio de Janeiro e a diminuição expressiva do volume de ações nas bolsas de investimentos ${ }^{5}$.

O governo de Fernando Henrique Cardoso deu continuidade ao processo de privatizações e, através da criação do PROER - Programa de Reestruturação e Fortalecimento do Sistema Financeiro Nacional - estabeleceu como prioritário o setor financeiro nacional, através do qual carreou recursos aos bancos que se encontravam em dificuldades e, em seguida, abriu aos grandes bancos internacionais a participação na privatização e desnacionalização do setor. Com o mesmo espírito, porém com meios distintos, ao setor produtivo privado nacional os governos neoliberais legaram a abertura comercial - promotora em muitos setores de concorrência desleal ${ }^{6}$-, as altas taxas de juros (desde o Plano Collor) e o câmbio supervalorizado (a partir do Plano Real). É certo que tal política promoveu o

\footnotetext{
5 "O fechamento da Bolsa de Valores do Rio de Janeiro, além de causar prejuízo às empresas produtivas, às corretoras e à economia em geral, talvez seja um derradeiro sinal de alerta à nação. A falta de foco em investimentos produtivos por parte da política econômica governamental torna as empresas reféns das taxas de juros, esvazia a poupança interna e, na mesma proporção, amplia a dependência externa" (Azevedo, Folha de S. Paulo, 29/05/2002).

${ }^{6}$ No setor de brinquedos, por exemplo, entre 1991 e 1995, das 848 fábricas associadas a Abrinq, 536 faliram (Atma e Troll, entre outras) ou entraram em concordata (Revista da Indústria, 15/jul/96. pp. 14-6). O clássico caso da indústria de brinquedos e têxtil, como também os setores de máquinas e equipamentos, autopeças, entre outros, tiveram como saldo da abertura comercial a falência de aproximadamente 50\% das empresas. Muitas daquelas que permaneceram no mercado tiveram, em algum momento, de se converter em importadoras. Cabe lembrar que não houve apenas a queda nas alíquotas de importação, impostos que incidiam sobre os produtos nacionais não incidiam sobre os similares importados, como o IPI.
} 
sucateamento do parque industrial e o aumento de falências e concordatas na indústria nacional ${ }^{7}$.

Um aspecto importante a ser considerado, no entanto, refere-se às discussões que já vinham ocorrendo na sociedade e também no âmbito do governo, referentes à questão da privatização, no período imediatamente anterior à década de 1990. Tais discussões aparecem, inicialmente, a partir de duas tendências tão díspares quanto inconciliáveis, opondo os "privatistas" e os "estatistas", em um jargão que poderia considerar a oposição da década de 1990 entre "monetaristas" e "desenvolvimentistas". Mencionadas como agentes das fusões e aquisições, no Brasil, as privatizações remetem à celeuma estabelecida entre essas tendências. O primeiro grupo avaliando a participação do Estado na economia como nociva e prejudicial à atividade econômica. O segundo, considerando a importância da participação das empresas estatais no processo de desenvolvimento econômico brasileiro, cuja economia cresceu 26 vezes no período compreendido entre 1930 e 1980, enquanto o Japão cresceu 14 vezes e o México cresceu cerca de 12 vezes. Apenas a União Soviética apresentou crescimento industrial similar ao do Brasil no mesmo período (Rangel, 1987, p. 43).

Rangel (1987), avaliava que era preciso ser estatista $\underline{e}$ privatista ao mesmo tempo, na medida em que no processo de desenvolvimento surgissem atividades que deveriam ser estatizadas enquanto outras deveriam ser privatizadas. Sua proposta de concessão dos serviços públicos, discutida e desenvolvida em trabalho junto a economistas do BNDE na década de 1980, considerava a "redistribuição das atividades econômicas entre os setores público e privado" (p. 17), através da substituição da "concessão de serviço público a empresa publica, pela concessão de serviço público a empresa privada" (p. 23) como forma de superar a crise e gerar novo ciclo de desenvolvimento econômico.

É preciso ressaltar que Ignácio Rangel não defendia a venda do patrimônio público de empresas como a Usiminas ou mesmo a Telebrás, empresas superinvestidas ou com capacidade de alavancar recursos (Pizzo, 1997, p.117) ${ }^{8}$. O objetivo principal das concessões

\footnotetext{
${ }^{7}$ Em 1996, ano da venda da Metal Leve para a alemã Mahle, era anunciado que a "abertura desenfreada aos importados, taxas altas de juros, câmbio valorizado e arrocho no crédito vão transformando setores inteiros da indústria brasileira em maquiladoras" (Revista Atenção, ano 2, n 7, 1996).

8 "Não se trata de você estar transferindo empresas com capacidade ociosa para a iniciativa privada. Porque isso, do ponto de vista da economia como um todo não representa nada, ou seja, transferir a Usiminas, a Mafersa, empresas carregadas de capacidade ociosa, não vai fazer, pelo fato de estarem na mão do setor privado, que elas invistam, porque elas estão superinvestidas. Você não precisa mais investir em equipamentos, porque ele já está investido, então é uma simples transferência de patrimônio, que, do ponto de vista macroeconômico, não significa nada" (Pizzo, 1997, p. 108).
} 
seria carrear recursos para os setores que necessitavam de investimentos, e diante das dificuldades financeiras do Estado, extremamente endividado, o setor privado seria o único em condições de assumir essa responsabilidade. A tarefa do Estado seria a de organizar e realizar a concessão dos serviços públicos nos setores carentes de investimentos ou ociosos.

Desde o início do presente trabalho sobre as fusões, aquisições e o processo de privatizações ocorrido no Brasil na década de 1990, as principais evidências motivadoras do tema referiam-se à concentração, centralização de capitais e desnacionalização dos setores produtivos da economia brasileira. Tais aspectos encontram-se correlacionados, pois como se procura demonstrar, ampliou-se a participação do capital estrangeiro no país nos mais diversos setores, principalmente através dos processos de aquisições de empresas ou participações.

Um levantamento inicial de dados referentes aos negócios ocorridos na primeira metade da década, e a tentativa de elaboração teórica que revelasse as causas e as conseqüências das diversas transações impulsionaram o estudo comparativo da adoção de políticas neoliberais nas economias mais dinâmicas da América Latina, sobretudo em relação ao México, Argentina e Chile, bem como o esboço de um panorama do movimento de fusões e aquisições nos países de centro do sistema capitalista, com menção aos EUA, Espanha, Inglaterra, França e Japão.

A opção pela realização de um levantamento amplo teve por finalidade a compreensão do processo de concentração e centralização de capital na fase atual de crise do sistema capitalista, considerando as especificidades da formação econômica e social de cada país. Nesse sentido, buscando estabelecer analogias e comparações entre economias, observando as diferentes escalas regionais diante das determinações do centro do sistema frente à conjuntura mundial.

No contexto internacional, observou-se que não havia homogeneidade na movimentação de negócios entre os países. Evidenciava-se que a onda de fusões e aquisições no Brasil decorria das políticas dos governos de Fernando Collor (1990-1992) e Fernando Henrique (1995-2002), que adotaram medidas econômicas liberalizantes, com a redução da participação do Estado na economia, cortes de gastos no setor de serviços públicos, nos investimentos em infra-estrutura, em saúde e educação, além da venda das empresas estatais.

Essa opção mostrou-se favorável à ampliação da participação estrangeira através de investimentos externos diretos e indiretos na economia brasileira, como verificado, por 
exemplo, nas declarações do então presidente do Banco Central, em 1998, ao interpretar o aumento dos investimentos estrangeiros no Brasil como o resultado da desvalorização das empresas brasileiras no mercado internacional, considerando positivo o endividamento destas 9 .

Por outro lado, o aumento da participação estrangeira na economia indicava uma reorganização territorial e espacial dos grupos e firmas nos diversos setores da economia. Verificou-se a predominância de negócios com participação estrangeira nos setores estratégicos da economia (Biondi, 1999; Gonçalves, 1999; Lesbaupin e Mineiro, 2002) como, por exemplo, no setor de telecomunicações com $60,8 \%$ de participação estrangeira, energia elétrica, gás e água, com 57,3\%, e no setor financeiro, com 59,0\%. Outros setores também demonstraram forte concentração de participação estrangeira: setor de alimentos, com 71,2\% de participação estrangeira; comércio varejista, 77,5\% de participação estrangeira; minerais não metálicos, 71,4\% de participação estrangeira; farmacêutico, higiene e limpeza, 98,2\% de participação estrangeira; maquinaria, 80,7\% de participação estrangeira, etc. (Ferraz e Iooty, 2000, p. 54).

As orientações econômicas dos governos liberais no transcurso dos anos 1990, divulgadas por estes como "modernizadoras", corresponderam às determinações oriundas principalmente do Banco Mundial e do Fundo Monetário Internacional. As prescrições do Consenso de Washington foram responsáveis pela "desregulamentação dos mercados financeiros e a abertura comercial irrestrita" (Tavares e Fiori, 1993, p. 77), afetando de maneira excessiva a economia nacional, bem como transformando o ambiente econômico em meio de competição predatória, no qual a empresa de capital nacional transformou-se em um frágil alvo do capital estrangeiro.

Em um quadro de intensificação da crise econômica, a burguesia nacional sofreu reveses, o que resultou em aumento da quantidade de falências, transferência de propriedade ou maior endividamento de empresas. Entretanto o setor social mais prejudicado foi o da classe trabalhadora, sobretudo com a retração do seu poder de compra e com o aumento dos índices de desemprego. Em vários momentos dos anos 1990 o desemprego atingiu um quinto

\footnotetext{
${ }^{9}$ Conforme Gustavo Franco: "Esse investidor (estrangeiro) enxerga no Brasil empresas que estão baratas para qualquer padrão internacional. E, portanto, você tem um movimento de entrada de investimentos muito grande" ("Empresa barata atrai capital, diz Franco", Folha de S. Paulo, 21/11/1998).
} 
da população economicamente ativa nos grandes centros urbanos do Brasil (Pochmann, 2001).

A conclusão possível, portanto, indica que as diretrizes políticas e econômicas implementadas no Brasil da década de 1990, com a abertura comercial e o fim da reserva de mercado de vários setores da economia, além das desregulamentações nas esferas da produção e nas relações de trabalho, aumentaram exponencialmente as transações entre as empresas, principalmente através do movimento de aquisições, fusões e pelo processo de privatizações realizado pelos governos federal e estaduais, com a intensificação do processo de concentração e centralização de capitais, o aumento do fluxo de investimentos estrangeiros e o processo de desnacionalização (Gonçalves, 1999, p. 81).

O trabalho está assim dividido: uma introdução, três capítulos e as considerações finais.

A Introdução tem por objetivo apresentar o trabalho de forma geral e circunscrevê-lo na década de 1990. O primeiro capítulo consiste em uma síntese do pensamento de autores relevantes na análise do tema, o exame de trabalhos mais recentes, além de apresentar algumas definições e discussões de base teórica do tema e sua interlocução entre as diversas abordagens.

O segundo capítulo pretende aproximar-se do assunto em termos práticos, e apresenta os processos de privatização e das transações realizadas em países como a Grã-Bretanha, o Chile, a Argentina e o México. Como há diferenças nos processos realizados nesses países, tenta-se destacar as peculiaridades de cada uma dessas economias. Neste capítulo, é ressaltado o precedente histórico de implantação das medidas neoliberais e implementação das privatizações.

O terceiro capítulo analisa as fusões e aquisições de empresas realizadas no Brasil, acompanhadas pelo processo de privatizações concretizado pelos governos no transcurso da década de 1990, e que atingiu também o setor bancário, com a abertura à participação dos bancos estrangeiros no mercado brasileiro, além das medidas criadas sob o rótulo do PROER para amparar os bancos em dificuldades financeiras. Discute-se a oportunidade das medidas econômicas implementadas sob a ótica do neoliberalismo e as suas conseqüências para a economia do país. 
O objetivo das considerações finais é o de apresentar uma síntese do trabalho, além de oferecer um balanço do processo desenvolvido no país, sob a ótica de medidas econômicas lesivas ao patrimônio nacional. 


\section{CAPÍTULO I - REFERÊNCIAS TEÓRICAS}

\section{I.1. Fundamentos teóricos da acumulação do capital}

A acumulação de capital, conforme Marx (1968 [1890]), é fator primordial do desenvolvimento da produção capitalista. Partindo, primeiramente, do capitalista individual a acumulação representa a reprodução simples do capital, no processo de produção sob o domínio do capitalismo, ou seja, a "retransformação da mais-valia em capital" que se realiza no investimento constante em novos meios de produção. A intensidade da acumulação de capital define o processo de concentração, concretizado no conjunto dos investimentos em meios mais modernos de produção, aplicado pelo capitalista. Mas, será a somatória desses investimentos concentrados, associados com a concorrência capitalista e a capacidade de endividamento que proporciona o processo de centralização do capital, com a eliminação dos capitalistas menos aparelhados ${ }^{10}$.

O processo de acumulação ocorre, em primeiro lugar, baseado no aumento da concentração dos meios de produção em poder de "capitalistas individuais" e, em segundo lugar, através da repartição "do capital social de cada ramo de produção (...) entre muitos capitalistas que se confrontam como produtores de mercadorias, independentes uns dos outros" mas que são concorrentes. Assim, a acumulação decorreria do aumento da “concentração (...) dos meios de produção e do comando sobre o trabalho" e também "da repulsão recíproca de muitos capitais individuais". Marx descreve a repulsão dos diversos capitais e a sua dispersão, acompanhada pelo processo de atração como determinante de outra conseqüência da acumulação, qual seja, a centralização propriamente dita, caracterizada pela “transformação de muitos capitais pequenos em poucos capitais grandes" (p. 726-727) ${ }^{11}$ A

\footnotetext{
10 “Todo capital individual é uma concentração maior ou menor dos meios de produção com o comando correspondente sobre um exército maior ou menor de trabalhadores. Cada acumulação se torna meio de nova acumulação. Ao ampliar-se a massa de riqueza que funciona como capital, a acumulação aumenta a concentração dessa riqueza nas mãos de capitalistas individuais e, em conseqüência, a base da produção em grande escala e dos métodos de produção especificamente capitalistas. O crescimento do capital social realiza-se através do crescimento de muitos capitais individuais. Não se alterando as demais condições, os capitais individuais e com eles a concentração dos meios de produção aumentam enquanto o capital social acresce." (Marx, 1968, p. 726).

11 "O capital se acumula aqui nas mãos de um só, porque escapou das mãos de muitos noutra parte. Esta é a centralização propriamente dita, que não se confunde com a acumulação e a concentração." (Marx, 1968, p. 727).
} 
centralização desenvolve-se com a concorrência e o crédito, que funcionam como alavancas, a partir da ampliação da produção e da acumulação capitalista ${ }^{12}$.

A acumulação do capital engendra a sua reprodução, e o capitalismo se desenvolve através de dois processos: concentração e centralização do capital, processos que não se encontram de forma casual ou acidental na raiz das transações envolvendo fusões e aquisições de empresas em diversos momentos históricos e em diversas empresas. Tais idéias parecem definir com bastante precisão o recorte temporal escolhido para tema desta pesquisa, com todas as fusões e aquisições de empresas realizadas no decorrer da década de 1990.

\section{I.1.1 A abordagem de Rudolf Hilferding}

Em O Capital Financeiro, Rudolf Hilferding ${ }^{13}$ retoma as questões formuladas por Karl Marx, em $O$ Capital, sobre o processo de acumulação do capital, considerando o capital financeiro como objeto de análise ${ }^{14}$. Hilferding (1985), parte das categorias dinheiro e crédito para analisar a expansão do capital através dos cartéis e das sociedades anônimas. A abordagem de Hilferding abrange a concentração e a centralização do capital nas grandes empresas, a evolução dos cartéis e dos trustes, a participação do capital financeiro e os desdobramentos desses processos na economia. As fusões e aquisições de empresas, por outro lado, formam em seu conjunto o movimento de centralização do capital.

Hilferding ressalta o lucro como o "propósito da produção capitalista", com a sua busca tornando-se o ideal da ação do capitalista, a partir "das condições da luta competitiva". Essa busca por um lucro cada vez maior resulta na "tendência à produção da mesma taxa média de lucro para todos os capitais", causa da procura por áreas com taxa superior a média e fuga de áreas onde a lucratividade tenha se tornado menor (p. 181).

\footnotetext{
12 "Além disso, o progresso da acumulação aumenta a matéria que pode ser centralizada, isto é, os capitais individuais, enquanto a expansão da produção capitalista cria a necessidade social e os meios técnicos dessas gigantescas empresas industriais cuja viabilidade depende de uma prévia centralização do capital. Hoje em dia, portanto, é muito mais forte do que antes a atração recíproca dos capitais individuais e a tendência para a centralização." (Marx, 1968, p. 728).

${ }^{13}$ HILFERDING, Rudolf. O Capital Financeiro. São Paulo: Abril Cultural, 1985 [.

${ }^{14} O$ Capital Financeiro, ao lado de $O$ Imperialismo, de John Atkinson Hobson, serviram de fontes para a elaboração de O Imperialismo: Fase Superior do Capitalismo, de Lênin.
} 
A associação de capital seria a forma precípua de centralizar o capital (p. 184), em uma análise que se refere ao afluxo de capitais para os setores de mais alta lucratividade, e ao seu posterior refluxo, após a diminuição da taxa de lucros ${ }^{15}$.

A queda da taxa de lucro também pode ocorrer em determinado setor por causa do correspondente "aumento do lucro em outro ramo da indústria". Deste modo, as diferenças na taxa de lucro podem ser vencidas através da associação de empresas, enquanto que o ímpeto causador da associação não será o mesmo conforme a conjuntura: na fase de prosperidade, este seria causado pelas "empresas manufatureiras, que com isso dominam os preços altos da matéria-prima ou até mesmo sua escassez" e; na fase depressiva, os setores ligados à produção de matéria-prima tenderiam a se associar às empresas manufatureiras para não serem obrigados a vender seus produtos por um preço inferior aquele de produção, isto é, a propensão do "ramo de negócio menos lucrativo se associar ao ramo mais lucrativo". Ao tratar das diferentes formas de surgimento da associação, Hilferding propõe que a distinção destas deva ser avaliada como: associação ascendente, como a associação de uma laminadora a minas de carvão ou a altos fornos; a associação descendente, quando, por exemplo, uma mina de carvão compra altos fornos e laminadoras; e a associação mista, conforme o exemplo de uma associação entre uma aciaria, por um lado, com minas de carvão, e por outro lado, com laminadoras (p. 189-192).

A associação resultaria da "diversidade da taxa de lucro", quando finalmente terminam as oscilações para a empresa associada. Isto decorre daquilo que Hilferding menciona como as vantagens da associação derivada da poupança do lucro comercial, que pode ser suprimida e, neste montante, ocorrer aumento do lucro industrial - pois com a associação de grandes empresas, o atravessador, ou "o comerciante e seu lucro" é eliminado, elevando na mesma proporção o lucro industrial. A concorrência estabelecida entre essas empresas associadas, com empresas isoladas, confere maior vantagem às primeiras, por conta do aumento da massa de lucro. Mas há mais vantagens decorrentes da associação, que compensariam as fases diferentes da conjuntura e, por isso, seria possível atingir uma taxa de lucro mais constante para a empresa associada. A associação também contemplaria a

\footnotetext{
15 "A tendência à compensação da taxa de lucro é importante para compreender o movimento da produção capitalista e a forma de ação da lei do valor como lei do movimento. Pois a lei do valor não domina diretamente o ato das trocas isoladas, mas apenas sua totalidade, da qual o ato da troca isolada é somente uma parte condicionada pelo conjunto. Por outro lado, a disparidade individual dos lucros é importante para a distribuição do lucro total, para a acumulação, concentração e, finalmente, para a associação, fusão, cartel e truste." (Hilferding, 1985, p. 187).
} 
possibilidade de um incremento no progresso técnico, e poderia auferir, com isso, um "lucro extra, em comparação com a empresa simples”. Outra vantagem, ainda, seria o fortalecimento da empresa associada, em relação à empresa simples, diante de uma forte depressão, pois "a queda dos preços da matéria-prima não se dá no mesmo nível que a queda dos preços dos produtos fabricados". Então, a forma de produção sob o capitalismo é acompanhada, desde o início, "pelo sistema de associação" que, ao mesmo tempo, significa "uma limitação da divisão do trabalho" e favorece um incentivo a uma nova "divisão do trabalho da nova empresa integral" (p. 192).

Hilferding atribui a aceleração do "sistema de associação na fase do desenvolvimento capitalista mais recente" aos impulsos resultantes principalmente da cartelização, e especifica que a associação resultante de causas econômicas "logo oferece oportunidade de melhorias técnicas do processo de produção". Tais vantagens podem impulsionar associações "onde as meras causas econômicas ainda não a provocaram”. Hilferding definiu a associação enquanto uma união entre empresas capitalistas, onde uma forneceria matéria-prima à outra, e também distingue a associação proveniente "da diversidade das taxas de lucro em distintos setores da indústria", da associação entre "empresas do mesmo ramo industrial". Esta surge com a finalidade "de aumentar a taxa de lucro nesse setor para além de seu nível inferior médio" através da "eliminação da concorrência". O primeiro caso aponta para uma inalteração das taxas de lucro naqueles "ramos industriais aos quais as empresas pertenciam antes de sua associação. Sua diferença perdura e desaparece somente para a empresa global associada". O segundo caso enseja a elevação do lucro como decorrência "da diminuição da concorrência". Teoricamente esta ocorre "pela associação de duas empresas". O fim da concorrência é interessante para ambas as empresas, que pelo seu novo tamanho podem dominar o mercado e, por exemplo, aumentar os preços, e reduzir os efeitos da concorrência ou, ainda, imediatamente após a associação usufruir sua nova posição e baixar os preços, e assim eliminar seus adversários, "sendo que o aumento da taxa de lucro só terá lugar quando esta meta for alcançada" (p. 193).

A associação pode assumir, ainda, duas formas: a comunidade de interesses, quando as empresas mantêm a sua independência e a união é estabelecida através de um contrato, e a fusão, quando ocorre a união de duas empresas em uma só. Uma e outra podem ser parciais, o que possibilita a continuidade da "livre-concorrência no ramo industrial correspondente - ou monopolista". Neste caso, o cartel seria definido como uma "comunidade de interesses 
monopolista" e o truste como "uma fusão monopolista". A comunidade de interesses e a fusão podem ser homogêneas quando abrangem "empresas do mesmo ramo de produção - ou $\operatorname{associadas}^{16}$ - empresas de ramos de produção complementares”, mas podem ocorrer, também, além destas mencionadas uniões, fusões parciais homogêneas ou associadas, cartéis e trustes homogêneos ou associados. Tanto as comunidades de interesse como as fusões podem se dar na indústria, no comércio e nos bancos. As associações são denominadas "homosféricas" quando ocorrem numa mesma esfera. Outras associações, por exemplo, resultantes da união de uma empresa comercial com um banco, de uma empresa industrial que abre uma empresa comercial ou de uma fábrica de sapatos que abre sapatarias nas grandes cidades "para venda direta aos consumidores", são denominadas "heterosféricas" (Hilferding, p. 193-194).

Em relação à associação parcial, "a comunidade de interesses ou fusão não limita a concorrência, antes reforça a empresa constituída pela combinação na concorrência frente às empresas isoladas". A associação homogênea causa diminuição da concorrência, no caso de uma associação parcial ou, quando de uma associação total, a sua eliminação. Há vantagens técnicas e econômicas decorrentes dessas associações: diferenciam-se conforme a natureza da empresa e o ramo da indústria. As vantagens técnicas podem ser suficientes para causar associações e fusões, enquanto comunidades de interesses e cartéis surgem das vantagens econômicas. A Classificação de cartéis e trustes é, então, entendida como: associações homogêneas e combinadas; associações parciais e monopolistas; e comunidade de interesses e fusão (Idem, p. 194-199).

\section{I.1.2 Lênin e a tese do imperialismo}

Para Lênin (2000 [1917]), o intenso crescimento da indústria e da concentração da produção em um número reduzido de grandes empresas representa uma das principais tendências do capitalismo no início do século XX, ou seja, a transformação da concorrência em monopólio. Também os bancos se transformam, de "modestos intermediários" em monopólios influentes, dispondo da quase totalidade do capital-dinheiro, dos grandes

\footnotetext{
${ }^{16}$ Hilferding utiliza os termos homogen e kombiniert, para designar a mesma coisa que os atuais termos integração horizontal e vertical (Hilferding, 1985, p. 194).
} 
capitalistas aos pequenos empresários, como também controlando os meios de produção e as fontes de matéria-prima de um país ${ }^{17}$. O auge do processo, conforme Lênin, resume-se na transformação do capitalismo em imperialismo, e nesse ponto Lênin considera imprescindível analisar a concentração bancária ${ }^{18}$.

$\mathrm{Na}$ Alemanha, a concentração bancária ocorreu em reduzido tempo, na passagem do século XIX para o século XX: em 1895 o total de estabelecimentos bancários era de 42; em 1900 esse número atingiu 80 estabelecimentos, e em 1911 alcançou o total de 450 estabelecimentos. Lênin assinala que à época muitos analistas que observavam estes dados consideravam-nos um processo de descentralização, porém não verificaram o processo de centralização de empresas, outrora dispersas, em uma "empresa capitalista única, nacional a princípio e mundial depois". Consistia, então, "na subordinação a um centro único de um número cada vez maior de unidades econômicas que antes eram relativamente 'independentes', ou, para sermos mais exatos, eram localmente limitadas”. Este movimento representava a centralização, ou o reforço e o fortalecimento do poder dos gigantes monopolistas. A exemplo da disputa entre dois dos mais importantes bancos berlinenses, o Deutsche Bank e a Disconto-Gesellschaft (Sociedade de Desconto de Berlim) que possuíam, respectivamente, 15 milhões e 30 milhões de marcos em 1870; em 1908 o capital do primeiro era de 200 milhões e o do segundo de 170 milhões; em 1914 o Deutsche Bank elevou seu capital para 250 milhões, enquanto a Disconto-Gesellschaft, após efetuar uma fusão com a Aliança Bancária Schaffhausen, elevou o seu para 300 milhões. Lênin apresenta como exemplo na França a concentração em três bancos: Crédit Lyonnais, Comptoir National e Société Générale, cujas sucursais e caixas aumentaram de 64 em 1870, para 258 em 1890 e para 1229 no ano de 1909 (p. 26-27).

Os dados apresentados por Lênin, relativos tanto ao capital bancário, como ao número de escritórios, das sucursais dos bancos e de suas contas correntes, demonstram uma "contabilidade geral" que envolve não apenas a classe capitalista, na medida em que os bancos recolhem os rendimentos em dinheiro dos patrões e dos empregados e também "de uma reduzida camada superior dos operários", o que resulta, formalmente, em uma

\footnotetext{
17 "Os bancos pequenos são afastados pelos grandes, nove dos quais concentram quase metade de todos os depósitos. E aqui ainda não se têm em conta muitos elementos, por exemplo, a transformação de numerosos bancos pequenos em simples sucursais dos grandes, etc." (Lênin, 2000, p. 24).

${ }^{18}$ Os dados assinalados por Lênin, referentes à Alemanha do início do século XX, foram os indicadores da concentração (Lênin, 2000, p. 30).
} 
"distribuição geral dos meios de produção" entre os bancos da época, em um número que variava entre 3 a 6 na França e 6 a 8 na Alemanha ${ }^{19}$.

Conforme Lênin, "a última palavra no desenvolvimento dos bancos é o monopólio" (p. 31), agora com um novo papel relacionado à indústria, dada a freqüência de suas operações (desconto de letras, abertura de contas, etc.) e a reunião em seu poder de capitais do setor. Isto favoreceria aos bancos o conhecimento pormenorizado da situação do capitalista, seu cliente, e resultaria em maior dependência do industrial, além do progressivo aumento "da união pessoal dos bancos com as maiores empresas industriais e comerciais". Igualmente, possibilitaria a fusão através da "posse das ações, (...) a participação dos diretores dos bancos nos conselhos de supervisão", de forma que, por exemplo, os seis maiores bancos de Berlim tinham representações (através de seus diretores) em um total de 751 sociedades de diversos ramos, como verificaria nas companhias de seguros, restaurantes, teatros, indústrias de objetos artísticos, etc.. Esses mesmos bancos possuíam, em 1910, em seus conselhos de administração, nada menos do que a participação de 51 grandes industriais, entre eles o diretor da Krupp, da companhia de navegação Hapag. Tais participações também acolhem a de membros do governo ou do parlamento, completando, assim, a união dos bancos com a indústria e o Estado. A partir destas, aperfeiçoam-se os grandes monopólios capitalistas, inclusive através da especialização dos dirigentes dos bancos (p. 32) em função da complexidade das suas novas relações com os diversos e diferentes ramos da indústria, ou com relações estabelecidas em seu conjunto ou em um âmbito mais geral, ou então, de maneira mais específica. A exemplo disto, quando um diretor responsabiliza-se pelas indústrias da parte mais industrializada do país, um outro se responsabiliza com as indústrias do setor elétrico, e assim por diante. Emerge, desta maneira, uma divisão do trabalho em função da maior complexidade oriunda do novo papel dos bancos - "acima dos negócios puramente bancários" - na busca de uma competência maior - para lidar com os "problemas gerais da indústria" ou com "os problemas especiais dos seus diversos ramos" -, a fim de preparar seus funcionários em determinada esfera de influência do banco em relação ao setor industrial em que opera.

\footnotetext{
19 "Mas, pelo seu conteúdo, essa distribuição dos meios de produção não é de modo algum 'geral', mas privada, isto é, conforme os interesses do grande capital, e em primeiro lugar do maior, do capital monopolista, que atua em condições tais que a massa da população passa fome e em que todo o desenvolvimento da agricultura se atrasa irremediavelmente em relação à indústria, uma parte da qual, a 'indústria pesada', recebe um tributo de todos os restantes ramos industriais." (Lênin, 2000, p. 29).
} 
Na França, Lênin observou similaridade no sistema, onde a diferença ocorre (engenheiros, estatísticos, economistas trabalhando na mesma seção) ou especialistas divididos por setores conforme as áreas de atuação das diversas companhias. O resultado desse processo é uma junção maior entre capital bancário e industrial (p. 33), com uma preponderância do primeiro sobre o segundo, o que ilustraria, no século XX, a passagem "do velho capitalismo para o novo, da dominação do capital em geral para a dominação do capital financeiro". Afirma que seria incompleta a definição de capital financeiro de Hilferding ${ }^{20}$, por não indicar que "o aumento da concentração da produção e do capital" leva ao monopólio, porém considera que a análise de Hilferding "sublinha o papel dos monopólios capitalistas". Assim é que, para Lênin "concentração da produção; monopólios que resultam da mesma; fusão ou junção dos bancos com a indústria: tal é a história do aparecimento do capital financeiro e daquilo que este conceito encerra" (p. 36).

Na interpretação de Bukharin (1988) a questão da definição econômica e do futuro do imperialismo torna-se uma questão de análise "das tendências de evolução da economia mundial e das prováveis modificações de sua estrutura interna” (p. 17-18).

Ao considerar a economia mundial enquanto uma rede imensa, "tecida de um emaranhado de laços econômicos os mais diversos, baseados nas relações de produção encaradas em sua amplitude mundial” (p. 57), Bukharin parece antecipar e decifrar parte do processo que, atualmente, é denominado por "globalização", sem que se ignore, com tal afirmação, a complexidade crescente das relações comerciais internacionais e a elevação da composição orgânica do capital, com o incremento de novas técnicas e da ciência, o surgimento da informática, o crescente desenvolvimento das telecomunicações, entre outros.

Bukharin analisa o imperialismo enquanto "a política do capital financeiro" (p. 103) e ressalta o fato de que esta política reveste-se, na verdade, por um "caráter de conquista" e pelo que, nas suas palavras, seria a característica do imperialismo, enquanto "valor historicamente definido", de constituir-se em uma "política de rapina do capital financeiro". O autor passa a examinar a concorrência capitalista "na época do capital financeiro", a partir da idéia da concentração e centralização do capital (p. 107-108).

\footnotetext{
20 "Capital financeiro é o capital que se encontra à disposição dos bancos e que os industriais utilizam" (Hilferding, O Capital Financeiro, 1985).
} 


\section{I.1.3 Trustes e cartéis conforme Lewinsohn}

Conforme Lewinsohn (1945 [1940]), a finalidade econômica da concorrência é a dominação do mercado, ou a imposição de uma derrota ao competidor, configurando essa luta uma tendência para eliminar a concorrência. Há, nesse caso, dois modos possíveis de atingir esse objetivo: o primeiro caso resulta da vitória de um dos concorrentes de tal maneira que força a desistência dos demais; o segundo caso decorre de um acordo que agrupa os oponentes em torno de objetivos comuns. Entre variantes e combinações intermediárias, o primeiro caso resulta no truste e o segundo no cartel (p. 11).

A concorrência que, por diversos meios, força a falência de um pequeno comerciante, ou de uma pequena empresa com dificuldades para permanecer no mercado, não alteraria a composição da empresa, apenas contribuiria para a exclusão de um adversário. Se, ao contrário, a loja ou empresa tivesse alguma importância, seria mais interessante apoderar-se dela, através de algum tipo de acordo que conduzisse, por exemplo, à venda de produtos produzidos pela grande empresa, a preços impostos, ou que a inserisse em uma rede de filiais, o que em princípio não alteraria o negócio, mas também eliminaria um concorrente. Tais procedimentos também são encontrados na indústria, como quando um grande estabelecimento controla oficinas menores e independentes entre si, entre outros exemplos. Duas espécies de concentração são identificadas: a concentração vertical, que ocorre em ramos ou setores diferentes, comparadas aos "andares diferentes de um edifício econômico", em oposição à concentração horizontal, junção “de empresas de um mesmo ramo e do mesmo grau de produção (fábrica de automóveis com fábrica de automóveis, mas também fábrica de tintas com indústria farmacêutica)" (Lewinsohn, p. 12).

A associação pode ocorrer, com alguma freqüência, pela tomada de iniciativa do competidor mais fraco em associar-se ao mais forte, em uma capitulação "antes que seja tarde demais", mas na maioria das vezes a associação não decorre de falência ou da capitulação do mais fraco, pois é com muita regularidade que duas empresas em condições de igualdade e de forma voluntária unem-se com o objetivo de aumentar a sua lucratividade, o que não conseguiriam sem a união.

Independente das causas das associações, elas resultam em unidades cada vez maiores, designadas na maior parte dos idiomas por "trust", termo que se origina no "direito inglês e prevê a transferência de capitais para um agente fiduciário (trustee) para que este lhes assuma 
a gestão" e serviu à formação do truste petrolífero da Standard Oil (1882). Diante dos diversos tipos de trustes (konzern, na Alemanha, consortium e groupe, na França), Lewinsohn, demonstra que as semelhanças entre esses trustes e os seus similares resultam da "tendência a expansão" enquanto "extensão do grupo econômico", "ligação financeira ou administrativa entre suas diferentes partes", como também têm por objetivo alcançar os maiores lucros "e uma posição mais poderosa na vida econômica". A diversidade das formas desse tipo de organização depara-se com a forma clássica de holding, espécie de "supersociedade" que administra os negócios ou controla financeiramente as demais empresas que a formam. Outro caso ocorre através da troca de ações, quando uma empresa coage as outras a capitularem e passa a conduzir a administração do truste. Também se verifica a fusão total ou parcial das empresas, o que não impede o agrupamento em torno desse núcleo de outras sociedades. Tais casos foram observados nos setores siderúrgico e químico, da Alemanha, motivados "pela necessidade de racionalização técnica” (Idem, p. 13-15).

Os trustes formados com o intuito de lucrar apenas com operações de compra e venda de empresas não apresentam necessariamente uma estratégia de atuação setorial, como o caso do truste alemão Stinnes, o maior da Europa no período entre guerras. Outro exemplo seria o da "união de interesses", corriqueiro até a I Guerra, com o objetivo delimitado de repartir lucros ou dividendos sem comprometer a independência das empresas. Em alguns desses casos, de grande êxito, chegou-se a uma "união mais estreita, e até mesmo a uma fusão" (idem, p. 15).

Em relação aos cartéis, Lewinsohn sustenta que eles seriam, ao menos em relação a sua finalidade, mais definidos que os trustes, pois enquanto estes, ao longo do tempo, deixaram de se preocupar exclusivamente com a supressão da livre concorrência, a tendência dos cartéis continua sendo a da eliminação ou obstrução da livre concorrência, pois aumentar os preços ou "impedir a sua baixa" é a sua finalidade (p. 16). Assim, os membros do cartel costumam preservar sua independência, principalmente a financeira, não sendo dirigidos por qualquer administração central, como no truste. Entretanto, os membros devem obedecer ao estatuto do cartel, sendo passíveis de punição quando ocorre alguma infração. O cartel exerce pressão moral sobre seus membros e também sobre os não membros, pois a não adesão ou a saída do cartel também é motivo da imposição de pressões materiais. Quanto à denominação do cartel na Alemanha e na França, apesar de certo desacordo, era comum encontrar organizações com a designação de sindicato e comptoir, respectivamente. 
Lewinsohn distingue dois grandes grupos de cartéis: aqueles que impõem aos membros obediência a métodos de negócios ou a preços iguais seriam os "cartéis de igualização", enquanto os "cartéis de quotas" seriam aqueles cujos membros dividem o mercado em quotas de "participação na produção ou nas vendas totais". Outro tipo, considerado "mais moderado", seria o dos cartéis que prescrevem "normas gerais a serem empregadas com a clientela", através da negação de créditos além de certos limites aos seus clientes, ao não permitirem descontos ou abatimentos, a serem obrigados a aceitar restrições na sua publicidade, convenções mais comuns entre os bancos, cartelizados em quase toda parte. Outra forma comum seria o cartel de preço, com acordos que garantiriam a manutenção de um preço mínimo ou de preços fixos (p. 16). Para realizar o cartel de preços, é necessário um rigoroso controle entre os membros (p. 17).

A tendência monopolista nos cartéis se evidencia quando há divisão regional dos mercados, ou seja, um grupo ou grande sociedade recebe o direito exclusivo para a venda de determinado produto em uma região, e os membros do cartel se comprometem a não entrar naquele mercado. Esse cartel assumiu grande importância no setor de transportes, por exemplo na França, onde "até a época de sua fusão, as companhias de estradas de ferro tinham delimitado suas esferas de interesses". Lewinsohn menciona exemplos de cartéis internacionais que dividem o mundo entre si, conforme suas áreas de interesse: das companhias de navegação da Alemanha, que antes da primeira guerra mundial buscaram com a International Mercantile Marine Company, grupo de companhias anglo-americanas controladas por J. P. Morgan, a repartição dos mares e oceanos entre si, tentativa malograda, mas que possibilitou delimitar portos de escala para os navios de diferentes linhas. Outro exemplo, também anterior à primeira guerra, refere-se à repartição de mercados para a exportação de mercadorias. Aos Estados Unidos coube a exclusividade, nessa divisão, do mercado da América do Norte, ao sul dos grandes lagos; em troca, eram obrigados a renunciar a qualquer exportação para fora da América. Inglaterra e França poderiam exportar para as suas respectivas colônias, e a Alemanha poderia escoar seus produtos no mercado sueco. "Para os outros mercados, foram fixadas quotas. Não se chegou a um acordo quanto ao mercado sul-americano, que assim permanecia livre para todos os países concorrentes" (Lewinsohn, 1945, p. 17-18).

Para Lewinsohn os cartéis podem transgredir a liberdade das empresas, e a idéia de que as empresas seriam dependentes nos trustes mas independentes nos cartéis não 
corresponderia à realidade, pois "as sociedades formando um truste são muitas vezes mais livres do que as pertencentes a um cartel rigoroso". A principal diferença entre um e outro se refere ao "dinamismo dos dois gêneros de organização", pois enquanto o cartel pode ficar restrito a um tipo de mercadorias ou serviços, o truste dissemina-se por diversos ramos e apropria-se do que for possível. Um cartel internacional, ou mundial, não pode funcionar sem fortes cartéis nacionais no mesmo ramo. Os trustes ignoram as fronteiras nacionais, e quanto mais controlam e participam de sociedades no estrangeiro, mais importantes eles se tornam. $\mathrm{O}$ cartel é estabelecido, geralmente, por um prazo determinado, por vezes bastante curto, de três a cinco anos, enquanto o truste desconhece delimitação temporal na sua organização, durando enquanto permanecerem as condições financeiras propícias para a sua existência, geralmente por períodos longos, variando entre vinte e oitenta anos ou por mais tempo (p. 18).

\section{I.1.4 Chandler e o crescimento das empresas}

Alfred Chandler comparou o desenvolvimento das grandes empresas na Inglaterra, na Alemanha e especialmente nos EUA, desde o final do século XIX, abordando a história e as causas da expansão dos empreendimentos e o papel das grandes empresas no crescimento econômico $^{21}$. Conforme McCraw (1998), o mais importante é que a obra de Alfred Chandler influenciou toda uma geração de estudiosos em países como Grã-Bretanha, França, Alemanha, Japão, Itália e Bélgica, e em disciplinas como história, economia, sociologia e administração (p.8).

Ao alcançar o grau de investimento necessário na produção e distribuição, e com a intenção de explorar as economias de escala e de escopo, haveria quatro maneiras da empresa crescer: 1) por associação horizontal; 2) por integração vertical; 3) através da expansão geográfica; e, 4) pelo emprego das tecnologias ou dos mercados das empresas para criar novos produtos. As duas primeiras maneiras são estratégias geralmente defensivas, uma forma

\footnotetext{
21 "O advento da grande empresa verticalmente integrada não mudou apenas as práticas dos industriais norteamericanos e das suas indústrias. Já aludimos aqui aos efeitos sobre os comerciantes, sobretudo atacadistas, e sobre os financistas, especialmente banqueiros de investimentos." (Chandler, A., In: McCraw, 1998, p. 64). “(...) a maior inovação na economia norte-americana entre a década de 1880 e a virada do século foi a criação da grande empresa na indústria norte americana. Essa inovação, como tentei mostrar, foi uma resposta ao crescimento do mercado nacional cada vez mais urbano que resultou da construção de uma rede ferroviária nacional - a força dinâmica da economia nas duas décadas e meia anteriores a 1880." (Chandler, A., In: McCraw, 1998, p. 64).
} 
de proteger os investimentos já realizados. Nas outras duas formas de crescimento, com os investimentos e com a capacidade organizacional anteriormente existente, as empresas aproveitavam para introduzir-se em novos mercados e em novas atividades (Chandler, A., in: McCraw, 1998, p. 330-331).

As aquisições ou fusões aconteceriam, em muitos casos, para permitir o controle eficaz da produção, do preço e dos mercados, pois somente ocorreria aumento da produtividade na associação horizontal quando, nas empresas adquiridas ou incorporadas, se estabelecesse o controle administrativo centralizado, e se racionalizasse o quadro de pessoal e as instalações para a obtenção de economias de escala e de escopo, como ocorreu no exemplo da associação da Standard Oil, quando as suas associadas se uniram legalmente na formação do cartel Standard Oil. Se as empresas incorporadas ou adquiridas não fossem, em termos administrativos, centralizadas e racionalizadas, mas continuassem agindo de forma autônoma, a empresa ampliada continuaria apenas como "uma federação de empresas". No caso da expansão vertical, através da aquisição de empresas no interior da cadeia de produção as razões seriam mais complexas, pois para ampliar a produção, diminuir custos, aumentar a produtividade e aumentar os ganhos em processos adicionais as empresas deveriam estar unidas por sistemas de transporte, pois se tornaria inviável o aumento da produção quando unidades de processos afins estivessem geograficamente separadas - como ocorre na fabricação de químicos, metais e máquinas. Em tais investimentos, o motivo para a expansão vertical seria defensivo, mas não como na associação horizontal, cuja finalidade poderia ser privar os concorrentes de suprimentos ou garantir o fornecimento constante de materiais com a finalidade de "manter as vantagens de custos em função da escala e do escopo" (idem, p. $331)$.

Então, quanto maior o investimento em "instalações com alto coeficiente de capital", ou "quanto maior o tamanho mínimo eficiente" - maior será a "necessidade de proteção contra os custos de transação”. Assim, como decorrência da maior concentração nas unidades de produção e nas fontes de suprimentos, maior será a possibilidade de integração em uma só empresa. A integração, entretanto, incide diretamente no crescimento das economias de escala ou de escopo, sobretudo quando surgiam diferentes fontes de suprimento com preços acessíveis e era preferível para os industriais adquirir os seus suprimentos no mercado ao invés de investir na sua produção. Esse investimento, por vezes, podia ser feito "como uma transação de títulos lucrativa", mas a maioria das empresas preferia incorporar unidades onde 
"a estrutura física e a capacidade organizacional existentes propiciavam-lhes nítida vantagem competitiva" (Chandler, A., In: McCraw, 1998, p. 332).

As associações, defensivas ou estratégicas, realizavam-se em resposta a "situações históricas específicas que variavam de uma época para outra, de um país para outro, de uma indústria para outra e até mesmo de uma empresa para outra”. Como, por exemplo, o caso da indústria automobilística dos EUA, no período entre guerras, quando "a Ford continuou verticalmente integrada, a General Motors adotava a política de controlar um quarto de seus fornecedores, e a Chrysler adquiria quase todos os seus suprimentos de produtores independentes" (Chandler, A., In: McCraw, 1998, p. 332).

Estratégias de expansão geográfica, determinantes para o desenvolvimento contínuo da moderna empresa industrial, foram realizadas geralmente a partir da exploração de vantagens competitivas em mercados distantes ${ }^{22}$, durante a primeira metade do século XX. Assim, com a evolução das estratégias de expansão geográfica e de diversificação de produtos, para utilizar a "capacidade organizacional gerada pela concorrência funcional" foi o que permitiu a neutralização da "inércia burocrática inerente a toda organização hierárquica de grande porte." Além dos incentivos que "levavam ao investimento direto no exterior", também as tarifas e outras medidas que aumentavam os custos dos bens exportados e motivavam a construção de fábricas no exterior, até mesmo para conter a concorrência, "explorar um mercado potencial", ou variar a produção para atender necessidades locais. Para tanto, esse investimento realizava-se partindo do princípio que a empresa detivesse "vantagem competitiva sobre os produtores locais" (Idem, p. 332-333) ${ }^{23}$.

A expansão da grande empresa integrada podia se dar tanto no exterior como em casa, "por motivos defensivos" com o objetivo de assegurar fontes de matérias primas para as suas fábricas, no próprio país ou, posteriormente, no exterior, mas principalmente quando esses suprimentos não existissem no país de origem e quando os empresários locais não

\footnotetext{
22 "A diversificação de produtos decorria da possibilidade de usar de maneira mais lucrativa as instalações e o pessoal empregados na produção, na comercialização e nas atividades de pesquisa, visando igualmente explorar as vantagens competitivas." (Chandler, A. In: McCraw, 1998, p. 332).

${ }_{23}$ "Obviamente a aquisição de instalações de produção em lugares distantes só acontecia depois de o vanguardeiro ter feito seus investimentos iniciais na produção, na distribuição e na administração. O primeiro incremento da produção geralmente ocorria com a ampliação do estabelecimento original, quando tal incremento propiciava maiores economias de escala e de escopo. À medida que a organização de comercialização se expandia geograficamente, surgiam oportunidades para reduzir os custos de produção, transporte e aprovisionamento montando no próprio país fábricas situadas mais perto dos novos mercados ou de fontes locais de suprimentos, matérias-primas ou mão-de-obra." (Chandler, A. In: McCraw, 1998, p. 333).
} 
explorassem o recurso, "como era o caso do investimento direto em campos petrolíferos, minas ou seringais". Contudo, a maior razão para investir no exterior, resultava da possibilidade de a empresa ampliar a sua participação nos outros países e assim poder reduzir seus custos de produção e de vendas nesses mercados (Chandler, A., In: McCraw, 1998, p. $333-334)^{24}$.

\section{I.2 Abordagens recentes sobre o período}

As associações entre empresas, que resultaram em processos de fusões e aquisições em território brasileiro, na década de 1990, provocaram uma literatura com enfoque organizacional desenvolvida principalmente por administradores, consultores de empresas e economistas. Esta abordagem, geralmente restrita ao âmbito da empresa, apresenta alguns aspectos: das "estratégias" (Héau, 2001; Rossetti, 2001; Dupas, 2001) 25 , das "oportunidades" e das "patologias" (Héau) 26 27, e do "choque cultural” (Barros, 2001) ${ }^{28}$. Rasmussen (1989), pouco antes da abertura comercial brasileira, analisa o aspecto estratégico ressaltando o "planejamento estratégico", os "benefícios" e os "planos de expansão", principalmente. De maneira geral, os trabalhos citados acima não se contrapõem às reformas na política econômica brasileira dos anos 1990, ou mesmo são complacentes com esta. Não há, então, tratamento da concentração e centralização de capitais, trata-se da abordagem no ponto de vista administrativo e organizacional das empresas.

\footnotetext{
24 "Por isso a maioria das empresas tornava-se multinacional montando fábricas para produzir sua linha básica em economias adiantadas e não em desenvolvimento, pois os melhores mercados estavam nas economias de maior porte e com renda per capita elevada. Por isso, também, só se investia em fábrica no exterior depois de investir na comercialização." (Chandler, A. In: McCraw, 1998, p. 334).

${ }^{25} \mathrm{O}$ termo "estratégia" - comum na literatura acadêmica e na imprensa especializada -, aplicado às fusões e aquisições, contempla as formas de atuação da empresa no futuro (curto, médio ou longo prazo). Assim, os diversos tipos de estratégias a serem adotadas marcarão o posicionamento ou a inserção da empresa frente a diferentes conjunturas.

${ }^{26} \mathrm{O}$ termo "oportunidade" designa a situação de possibilidade de realização de um novo negócio. Refere-se, por exemplo, à possibilidade de aquisição de outra empresa, em um quadro de excesso de liquidez ou ao interesse dos herdeiros de uma empresa em transferir o negócio fundado por seus antepassados (Héau, 2001).

${ }^{27}$ Denominam-se "patologias" os problemas não previstos nas aquisições, que podem causar o fracasso dessas transações. Decorrem, basicamente, de um mau negócio ou de uma integração insuficiente na seqüência de uma fusão (Héau, 2001).

28 "Choque-cultural" evidencia a dificuldade de entrosamento entre estruturas diferentes. A busca por uma empresa, para fusão ou aquisição, considera possíveis semelhanças, e quanto maiores forem essas semelhanças, maiores serão as possibilidades do processo não resultar em um fracasso (Barros, 2001).
} 
Os trabalhos de Miranda \& Martins (2000), Gonçalves (1999 e 2000), Ferraz \& Iootty (2000), Bonelli (2000) e Barros (2001 e 2003), ressaltam o crescimento das transações envolvendo fusões e aquisições de empresas ocorridas no Brasil e no centro do sistema capitalista (EUA, União Européia e Japão), principalmente a partir da década de 1990.

Ferraz e Iootty consideram de alta relevância para a análise econômica o "processo de fusões e aquisições em curso nas principais economias do planeta", cujo crescimento revelouse exponencial durante a última década. Constatam a ocorrência de uma aceleração internacional dos fluxos de bens, serviços, tecnologia e capital, além da intensificação do processo de transformações tecnológicas e de "mudanças nos regimes nacionais de incentivos e regulação, em busca de uma liberalização econômica". As fusões e aquisições resultariam, portanto, de estratégias empresariais em busca da imposição de novos padrões de consumo e a exploração "de mercados com amplitude global, antecipando ou em resposta às mudanças no ambiente competitivo onde operam", consistindo em um tipo de empresa que busca a sua expansão além das fronteiras nacionais (p. 39).

Ferraz e Iootty assinalam que a grande participação de empresas estrangeiras em fusões e aquisições acentua a concentração econômica, e podem causar a internacionalização patrimonial interna, além da substituição ou adiamento de investimentos em ampliação de capacidade produtiva (p. 39). Ressaltam que o entendimento destes aspectos seria importante para o verdadeiro conhecimento da profundidade do processo de fusões e aquisições ocorrido no Brasil, mas que o conhecimento do processo seria parcial atualmente, no país, exceção feita ao artigo de Miranda e Martins (2000).

Miranda \& Martins (2000) consideram a ocorrência do "crescimento continuado do movimento de fusões e aquisições de empresas" e que este aponta para uma crescente tendência de concentração e de centralização do capital (p. 67). Estes autores contribuem, também, com uma metodologia para a análise dos dados divulgados pelas empresas de consultorias em fusões e aquisições, notadamente a KPMG Corporate Finance e a Securities Data, cujos dados foram utilizados e comparados no trabalho ${ }^{29}$.

Vegro e Sato (1995) demonstraram o crescimento de fusões e aquisições no setor de alimentos, tendo realizado considerações referentes ao crescimento das firmas (onde ressaltam

\footnotetext{
${ }^{29}$ Miranda \& Martins (2000) sistematizaram os dados para proceder a uma análise científica do assunto, em uma tentativa de diminuir as discrepâncias referentes ao montante de transações efetivamente realizadas ou quanto aos valores envolvidos nos negócios, através de uma série de comparações.
} 
processos de diversificação e aquisição). Apresentam dados e procuram caracterizar o fenômeno, além de identificar as principais transações ocorridas com a participação de empresas transnacionais, com um maior detalhamento no ramo de produtos lácteos e de carnes e óleos. Ressaltam que as fusões e aquisições não seriam um privilégio dos países centrais, com a ocorrência de importantes negócios em países em desenvolvimento (p. 9).

Triches (1996) aponta o dinamismo característico do mercado brasileiro durante os anos 1990 quanto às fusões e aquisições, apresenta uma definição dos termos mais utilizados na literatura e, em termos gerais, com alguns dados e informações de transações realizadas no período 1985-1994. Triches atribui à crise enfrentada pela economia brasileira na década de 1980 e no começo da década de 1990, o aumento das transações então verificado ${ }^{30}$.

Comin (1996) apresenta um panorama da situação das fusões e aquisições no mundo, analisa mais detalhadamente o caso dos EUA, onde a atividade seria mais intensa e aponta dados referentes à América Latina. O intento de Comin é mostrar "que o mundo vive hoje uma nova 'onda de fusões', com o crescimento sem precedentes do processo de centralização de capital” (p. 63). Reforça o caráter financeiro do processo.

Rodrigues (1999) analisa o que determinou o aumento da participação das empresas estrangeiras, no início da década, nas fusões e aquisições nos setores de autopeças e alimentos/bebidas. Compara o aumento dos ingressos líquidos de investimento direto estrangeiro (de US\$ 397 milhões em 1993, para US\$ 1,9 bilhão em 1994, US\$ 9,4 bilhões em 1996 e US\$ 17 bilhões em 1997) com estimativas da SOBEET que mostram o crescimento do Brasil, "na ponta vendedora", em relação ao volume de transações internacionais, da seguinte ordem: de US\$ 1,3 bilhão em 1994, alcança US\$ 2,1 bilhões em 1995 e US\$ 4 bilhões em 1996 (p. 5).

Lodi (1999) refere-se às fusões e aquisições realizadas no cenário brasileiro, e apresenta as biografias de algumas empresas familiares nacionais. Este autor baseia-se em sua experiência profissional como consultor de empresas. Além da sua experiência empresarial, o autor também trabalhou na imprensa, escrevendo artigos para jornais e, durante certo período, manteve uma coluna sobre negócios na Revista Carta Capital.

\footnotetext{
30 "A crise (...) e a abertura de mercado levaram muitos grupos empresariais, que tinham diversificado suas atividades, a vender ou a incorporar empresas para concentrar esforços nos ramos industriais considerados de maior domínio. A recessão, as altas taxas de juros praticadas no mercado financeiro, a implementação de sucessivos planos de estabilização, o congelamento de preços e salários e o problema de sucessão familiar foram os principais fatores que forçaram a venda de muitas empresas" (Triches, 1996, p. 20).
} 
Gonçalves (1999 e 2000) aponta as correlações entre a "globalização", a centralização do capital e a desnacionalização da economia brasileira, principalmente através do aumento de investimentos externos diretos e as fusões e aquisições realizadas no Brasil.

Bonelli (2000) ocupa-se das fusões e aquisições no âmbito do Mercosul, onde observa as estratégias das empresas transnacionais. Indica que existe relação entre os processos de abertura, integração e estabilização econômica ocorridos na América Latina com o recente movimento das fusões e aquisições.

Cano (1999) analisa as reformas econômicas e as consequiências da abertura em países da América Latina, e relata os processos de privatização empreendidos nos diversos países da região (Argentina, Brasil, Chile, Colômbia, México, Peru e Venezuela).

Barros (2001 e 2003) organizou duas coletâneas que tratam do processo de fusões e aquisições e seus impactos na economia brasileira. Os artigos convergem para uma análise favorável ao movimento em curso como, por exemplo, Rossetti (2001), em que as fusões e aquisições teriam propiciado aumento da competitividade e seriam resultantes de um amplo processo de modernização, no decorrer dos anos 1990.

\section{I.3 Tipologia e causas do recente movimento internacional de fusões e aquisições}

Gonçalves (2000) distingue os diversos tipos de fusões e aquisições, assinalando as principais definições (p. 81):

i. fusão estatutária: apontada como a combinação entre duas empresas, causando o desaparecimento de uma delas;

ii. fusão subsidiária: seria a junção entre duas empresas, onde uma torna-se a matriz e a outra, conseqüentemente, resultaria em sua subsidiária;

iii. fusão horizontal: quando dois competidores se fundem;

iv. fusão vertical: ocorre com uma empresa fornecedora;

v. Conglomerado: acontece quando as empresas não possuem relação direta entre si;

vi. Consolidação: junção entre duas ou mais empresas para a formação de uma nova empresa; vii. Aquisição ou takeover: envolve ação unilateral, sem negociação, através de oferta de compra de ações;

viii.Joint venture: caracterizada pela criação de uma nova empresa, ou pela realização de um acordo entre duas empresas, cada uma delas participando com ativos de sua propriedade. 
Rossetti (2001, p. 72) conceitua os diversos tipos de negócios, realizando uma “descrição sumária” dos mesmos, nos seguintes termos:

- Aliança: seria uma "associação entre duas ou mais empresas que empenham recursos comuns para juntamente desenvolverem uma nova atividade";

- Joint venture: definido como "união de risco", seria uma "associação de empresas para o desenvolvimento e execução de projetos específicos sem caracterizar sociedade ou nova companhia";

- Consórcio: formação de um grupo de empresas com o objetivo de adquirir outra empresa, executar uma obra ou financiar "projeto de grande envergadura";

- Contrato de longa duração: realizado através de "acordo, pacto ou convenção entre empresas para a execução de atividade comum";

- Fusão: definido como a união de duas ou mais companhias para a formação de uma única empresa, em geral sob o controle da maior ou mais próspera dentre elas;

- Aquisição: quando uma empresa adquire o controle acionário de outra.

Pode-se observar, entre as causas principais para o aumento das fusões e aquisições mundiais, razões estratégicas, por parte das grandes empresas, que procuraram se concentrar em seus negócios mais importantes, dispensando os negócios menos importantes, e a busca de maior sinergia em seu setor principal de atuação através de alguma forma de associação (Bonelli, 2000a, p. 65).

Em relação às causas, ou aos principais determinantes de cada uma dessas formas de fusões e aquisições, pode-se apontar as seguintes:

- sinergia: quando as empresas buscam sinergia, elas podem estar buscando economias de escala (aumento da escala de produção e redução do custo médio), pois "ao duplicarmos os fatores de produção pode-se verificar que o volume de produção mais do que duplica". Outra alternativa pode ser baseada "na economia de escopo (...) quando o mesmo conjunto de insumos pode ser usado para produzir uma ampla gama de bens e serviços" (Gonçalves, 2000, p. 82). Pode ocorrer, também, busca de sinergia financeira, que visa basicamente reduzir os custos de captação de recursos;

- diversificação de risco: neste caso, a estratégia de fusões e aquisições aparece nos conglomerados, ou é deles característica, como resposta, por exemplo, a turbulências nos mercados. Exemplos dessa estratégia seriam os conglomerados japoneses e coreanos, além da GE, que opera na indústria e também em serviços. “A expansão das F\&A's 
transfronteiriças nos últimos anos tem envolvido uma diversificação geográfica de investimentos que permite a redução da volatilidade da taxa de retorno dos investimentos em escala global“" (idem, p. 82);

- reestruturação produtiva: essas estratégias resultam de "mudanças nas condições de competitividade e lucratividade das empresas", causadas em grande parte pelo aumento da concorrência internacional, e aspectos relacionados a "mudanças tecnológicas e organizacionais". A reestruturação produtiva incentivou grande parte das transações na Europa, durante a década de 1980, quando da iminência do processo de integração européia, como reação das empresas "ao estabelecimento do mercado comum e à criação de um cronograma de união monetária" (idem, p. 84);

- acesso à tecnologia: “(...) o processo de F\&A's responde, em grande medida, à necessidade de obter uma tecnologia que é um ativo específico à propriedade de outra empresa" (p. 84). Na maior parte dos casos, quando o motivo é o acesso à tecnologia, as empresas preferem realizar alianças estratégicas, joint ventures ou acordos de cooperação;

- desregulamentação: processo que pode incentivar as empresas a uma integração vertical para aumentar seu poder de mercado, como exemplificado pela indústria de alumínio, que investiu na indústria de latas. Também a "desregulamentação dos mercados e a liberalização com relação à entrada de investidores estrangeiros tendem também a influenciar o processo de F\&A's. Em ambos os casos as empresas existentes com menor capacidade de competição tornam-se 'presas'“ (Gonçalves, p. 85);

- privatização: processos marcados por "transferência de ativos de propriedade estatal para investidores privados tem sido um dos principais mecanismos para aquisições cross border“ (idem, p. 85), como é evidente no caso da América Latina;

- incentivos fiscais: na forma de benefícios tributários, podem ser importantes para a realização de fusões e aquisições, quando há créditos a serem transferidos ou perdas que podem ser compensadas;

- estratégia de crescimento: “as F\&A's podem ser a forma mais eficaz de entrada em setores com os quais as empresas não têm familiaridade" ou pode existir, ainda, "excesso de capacidade produtiva e um número excessivo de competidores", como é o caso, ao que parece, da indústria automobilística, setor onde se prevê a permanência de seis grandes grupos (Gonçalves, p. 85). 


\section{I.4 A "globalização" e o movimento de fusões e aquisições}

A idéia de "globalização" tem revelado certa polêmica, evidenciada principalmente no âmbito da academia. Esse tema suscita alguma apreciação, na medida em que aparece na literatura sobre as fusões e aquisições de forma um tanto consensual, consonante com as versões oficiais. Alguns aspectos são apresentados, aqui, em relação ao tema das fusões e aquisições, entretanto sem a pretensão de esgotá-lo.

O movimento de fusões e aquisições disseminou-se pela economia mundial e tem sido interpretado como uma das características do período de "globalização" (Ferraz \& Iootty, 2000). Entretanto, este processo de "globalização" econômica não teria sido suficientemente explicado, conforme entendimento de Lacerda (1999), mas para Hirst e Thompson (2001) o conceito de "globalização" teria se transformado em uma moda das Ciências Sociais, e para Cano (1999) ele teve "um uso generalizado e banalizado na imprensa e mesmo na academia" (p. 37).

Para P. N. Batista Jr. (1997), o termo "globalização" seria inadequado e transmitiria "uma idéia incorreta do que passa no mundo hoje" e deveria ser utilizado apenas "entre aspas para denotar distanciamento e até ironia" (p. 06). Este termo, carregado de ideologia, serviria para divulgar "a idéia de que existe um processo irresistível na economia mundial", qual seja, o de adaptar-se "a esse movimento inexorável da economia, comandado por forças tecnológicas e pelas grandes corporações, ditas transnacionais, que operam no plano internacional" (p. 07).

A fim de evitar qualquer "mal-entendido", Batista Jr. ressalta, entretanto, ser

inegável o aumento das transações econômicas internacionais, apoiado em progressos tecnológicos e inovações em áreas como informática, telecomunicações e finanças. Nos últimos 30 anos, houve crescimento expressivo do comércio internacional de bens e serviços, dos investimentos diretos e dos empréstimos e financiamentos internacionais. Mas é preciso resguardar-se contra a carga de fantasia e mitologia que se constrói em cima dessas tendências reais, que são bem mais limitadas do que sugere o barulho em torno do assunto (Batista Jr., 1997, p. 07).

Ainda assim, é necessário discutir não tanto o conceito de "globalização", ou seja, esta discussão não deve ser reduzida apenas a uma questão semântica, mas precisa considerar outros aspectos, como por exemplo a estratégia "liderada pelos EUA em relação à América Latina" que procura alcançar "a abertura comercial indiscriminada dos mercados nacionais e 
assim a quebra da reserva de mercado, a desindustrialização, e a diminuição da soberania já limitada que desfrutamos" (Mamigonian, 1999, p. 140).

Em sua análise sobre a "globalização", Santos (2000) observa que os "últimos anos do século XX foram emblemáticos, porque neles se realizaram grandes concentrações, grandes fusões, tanto na órbita da produção como na das finanças e da informação" (p. 46) e critica os defensores do estado mínimo, pois a respeito das privatizações considera que estas decorreram de um "discurso" que tentava convencer a sociedade da necessidade de "haver menos Estado", tendo por base "o fato de que os condutores da globalização" necessitariam “de um Estado flexível a seus interesses”. Em sua análise, as privatizações seriam o exemplo da extrema voracidade do capital ${ }^{31}$.

Como as privatizações foram realizadas sob a ótica da "desoneração" dos Estados Nacionais, com o intuito de retirar de seu controle uma série de empresas importantes ou estratégicas, os capitais privados, notadamente estrangeiros, foram os maiores beneficiários de seus efeitos. Como conseqüência, observa-se a ampliação de mercados e a radicalização de relações de produção nessas economias, inseridas em condições de desigualdade no processo de globalização ${ }^{32}$.

\section{I.5 Ignácio Rangel e a concessão de serviços públicos}

Como foi mencionado na introdução deste trabalho, Ignácio Rangel elaborou uma proposta de concessão de serviços públicos a iniciativa privada, e a discutiu com técnicos do BNDE (Pizzo, 1997, p. 104-105) com o propósito de superar tanto a crise financeira como a

\footnotetext{
31 “(...) o capital se tornou devorante, guloso ao extremo, exigindo sempre mais, querendo tudo. Além disso, a instalação desses capitais globalizados supõe que o território se adapte às suas necessidades de fluidez, investindo pesadamente para alterar a geografia das regiões escolhidas. De tal forma, o Estado acaba por ter menos recursos para tudo o que é social, sobretudo no caso das privatizações caricatas, como no modelo brasileiro, que financia as empresas estrangeiras candidatas à compra do capital social nacional. Não é que o Estado se ausente ou se torne menor. Ele apenas se omite quanto ao interesse das populações e se torna mais forte, mais ágil, mais presente, ao serviço da economia dominante" (M. Santos, 2000, p. 66).

32 "A nação é, sem dúvida, uma categoria histórica, uma estrutura que nasce e morre, depois de cumprida sua missão. Não tenho dúvida de que todos os povos da Terra caminham para uma comunidade única, para 'Um Mundo Só'. Isto virá por si mesmo, à medida que os problemas que não comportem solução dentro dos marcos nacionais se tornem predominantes e sejam resolvidos os graves problemas suscetíveis de solução dentro dos marcos nacionais. Mas não antes disso. O 'Mundo Só' não pode ser um conglomerado heterogêneo de povos ricos e de povos miseráveis, cultos e ignorantes, hígidos e doentes, fortes e fracos" (Ignácio Rangel, in Mamigonian, 1997).
} 
crise cíclica em geral, através de uma redistribuição das atividades entre o setor público e o setor privado da economia.

É preciso ressaltar, antes de tudo, que o instrumental teórico de Rangel considerava a teoria dos ciclos, e assim avaliava a situação do país em relação a uma crise econômica emanada do centro do sistema, portanto uma crise externa, relacionada ao ciclo longo ( $4^{\circ}$ Kondratieff), coincidente com a crise do ciclo interno de curta duração (denominado ciclo de Juglar). É no quadro coincidente, portanto, de uma crise externa e de uma crise interna que Rangel reflete sobre a economia do país e procura soluções para a superação da crise com a retomada do desenvolvimento (Rangel, 1983, p. 11).

Rangel (1985) analisava o desenvolvimento econômico e industrial do Brasil pela "ação concomitante e coordenada" (p. 39) entre o setor público e o setor privado, mas entendia que as partes correspondentes a cada um desses setores mudariam a cada ciclo. Assim,

sempre que o empresariado privado se julga em condições de assumir a responsabilidade por um grupo de atividades, começa a pressionar pela privatização desse setor, o que não impede que o mesmo empresariado entre a cobrar do Estado certos serviços e produtos que, afinal, irão recompor o setor público desfalcado, na fase final da crise. Afinal, depois como antes, haverá, lado a lado, um setor público e um setor privado, em conflito que não exclui colaboração, e, em colaboração, que não exclui conflito. Dialeticamente. (Rangel, 1985, p. 39).

Sua proposta considerava o esgotamento da capacidade de investimento do Estado, causada por um endividamento que o tornava incapaz de gerar novos investimentos nos setores mais necessitados da economia, como em infra-estrutura, transporte urbano, energia, água e esgoto, ou seja, todos aqueles "serviços públicos que se atrasaram no seu funcionamento e hoje são as áreas estranguladas" (Pizzo, p. 107). Seu argumento incidia na utilização da capacidade de produção interna, de indústrias que estavam operando com altos índices de ociosidade, notadamente a indústria pesada, a de construção e o setor exportador, setores com capacidade de angariar recursos e de realizar investimentos. Isso ocorreria através da transferência às empresas privadas das empresas públicas que careciam de investimentos, associadas aos setores estrangulados da economia, e que portanto eram os que mais 
necessitavam de investimento, e, conforme Pizzo $(1997)^{33}$ não a transferência de empresas que estavam funcionando bem (como nos citados casos da Usiminas e Telebrás, além da Companhia Vale do Rio Doce e outras empresas) ${ }^{34}$.

\section{I.6 Conclusões}

A discussão sobre a "globalização" é um dos aspectos relevantes na associação do tema com a Geografia, conferindo importância à abordagem do território e do espaço, enquanto conceitos da disciplina, além da discussão referente ao novo papel conferido ao Estado. Neste ponto, parece existir um debate importante para a Geografia, distinguindo o tema de áreas administrativas e empresariais, pois não bastaria discuti-lo apenas em termos dos benefícios resultantes para a economia das empresas ou para as suas estratégias, mas também em termos da dinâmica econômica do país no longo prazo, com base em um desenvolvimento que gere crescimento econômico, aumento do emprego, a absorção dos setores empobrecidos, e ao menos a diminuição da desigualdade social, etc..

Com referência ao objetivo deste trabalho, de analisar o movimento de fusões e aquisições no Brasil, na década de 1990, estabelecendo analogias com a América Latina e com o centro do sistema, as fontes bibliográficas dividem-se em: referencial teórico do materialismo histórico e textos atuais tratando do objeto dialético de análise que comportam dados e análises considerados relevantes.

Além disso, parece importante resgatar o pensamento e a contribuição do economista Ignácio Rangel, na elaboração de uma proposta de concessão de serviços públicos à iniciativa privada, enquanto uma proposta inovadora e contraponto alternativo e não entreguista, frente à proposta finalmente implementada, que se notabilizou pelo cumprimento fiel das orientações emanadas dos organismos financeiros internacionais, com a entrega do patrimônio público social, em muitos casos com financiamentos para empresas estrangeiras através do

\footnotetext{
33 "Venderam-se empresas do setor petroquímico, do siderúrgico, etc. Nem por isso se resolveu a questão macroeconômica, a da economia como um todo. Houve uma simples transferência de patrimônio. Quer dizer, não era disso que Rangel estava falando" (Pizzo, 1997, p. 108).

34 "Chegamos, pois, ao ' $x$ ' do problema nacional, a saber: o quadro institucional atual dos serviços de utilidade pública - concessão de serviço público a empresa pública - esgotou suas possibilidades, porque conduziu a uma taxa de juros proibitivamente elevada, incompatível com a economia desses serviços. A tragédia do endividamento interno e externo prende-se a isso. É indispensável fazer intervir no processo outra grandeza: que não pode ser senão a garantia hipotecária" (Rangel, 1987, p. 22).
} 
Banco Nacional de Desenvolvimento Econômico e Social - BNDES. Ou seja, o banco cujas iniciais simbolizam o desenvolvimento econômico e social do país passou a financiar empresas estrangeiras na aquisição de empresas brasileiras. Algo tornado possível, historicamente, apenas no governo de Fernando Henrique Cardoso. Por isso, pode-se afirmar, "apenas" no governo entreguista de FHC. 


\section{CAPÍTULO II - AS TRANSAÇÕES DOS ANOS 1990 E AS PRIVATIZAÇÕES NO CHILE, ARGENTINA E MÉXICO}

\section{II.1 Precedentes históricos do modelo de privatizações e de reformas econômicas}

Transações entre empresas, através de diferentes formas de associações, como fusões e aquisições, são encontradas na história das empresas e acompanham o desenvolvimento do sistema econômico. Uma referência a fusões encontrada em Pécora (1972b), menciona a ocorrência de três grandes ondas de fusões nos Estados Unidos: a primeira, em 1899, quando ocorreram 1208 negócios, e surgiram empresas como: US Steel Corp., General Electric, Dupont, Anaconda, etc.; a segunda onda teria ocorrido entre 1925-1931, época de criação da General Foods, Catterpillar, United Aircraft, etc.; a terceira onda, maior que as anteriores, irrompeu ao final da II Guerra: surgiram General Dinamics, 3M, Campbel Soup, Textron, entre outros casos. Naquele país, as fusões saltaram de 235 negócios (em 1951), para 635 (em 1960), e nove anos depois (1969) atingiram 5500 negócios (p. 12). Triches (1996), aponta uma quarta onda na década de 1980, e confirma, portanto, a existência das mencionadas ondas de fusões e aquisições, além de indicar a primeira metade da década de 1990 como "a quinta onda de grandes associações entre organizações empresariais que envolveram cifras bilionárias" (p. 14 e 30).

A abordagem das transações relativas às privatizações e outras formas de associação entre empresas, ocorridas na década de 1990, deve considerar o caso da Grã-Bretanha, um antecedente histórico ao processo de privatizações e que se transformou em modelo e exemplo para diversos países executarem as suas reformas no âmbito das políticas neoliberais ${ }^{35}{ }^{36}$.

\footnotetext{
${ }^{35}$ Conforme Pirie e Young (1988), o programa de privatizações britânico teria sido copiado por mais de 50 países (p. 73).

36 "O modelo inglês foi, ao mesmo tempo, o pioneiro e o mais puro. Os governos Thatcher contraíram a emissão monetária, elevaram as taxas de juros, baixaram drasticamente os impostos sobre os rendimentos altos, aboliram os controles sobre os fluxos financeiros, criaram níveis de desemprego massivos, aplastaram greves, impuseram uma nova legislação anti-sindical e cortaram gastos sociais. (...) Esse pacote de medidas é o mais sistemático e ambicioso de todas as experiências neoliberais em países de capitalismo avançado" (Anderson, 1995, p. 12).
} 
Com a eleição de Margaret Thatcher em $1979^{37}$, iniciou-se o processo de mudanças na Grã-Bretanha, viabilizado primeiramente pelas privatizações. Foram vendidos ativos públicos e as ações das empresas estatais foram oferecidas na bolsa de valores, por toda a década de 1980. Na primeira fase do processo, foram vendidas as moradias públicas para seus inquilinos, além de outras propriedades públicas, como os denominados "monopólios naturais" e também os serviços sociais, através de leilões, para consórcios, empresas e bancos (Ribeiro, 1997, p. 100-101) ${ }^{38}$.

Na Grã-Bretanha, naquele período, foi comum a venda subvalorizada de parte das ações que o Estado detinha nas empresas ${ }^{39}$. O início da privatização das empresas estatais britânicas foi moderado, com a venda de algumas poucas ações da British Petroleum (1979) ${ }^{40}$. A partir desse primeiro momento, foram vendidas de forma intermitente, a Associate British Ports (1983), a British Gás (1986), a British Airways (1987), a Rolls Royce (1987), além de empresas como a British Airports, a Leyland Bus, a Jaguar, a British Coal, a National Freight Corp., os serviços de hovercraft no Canal da Mancha, o estaleiro Vickers, a British Aerospace, etc. (Pirie, 1988, p. 20-21 e Pirie e Young, 1988, p. 35).

No caso da privatização da British Telecom, a oposição dos sindicatos e do Partido Trabalhista obrigou o governo a adotar medidas que modificaram o processo de privatização da empresa. Houve o engajamento de bancos de investimentos no negócio e uma intensa campanha publicitária. A direção da empresa assumiu um Conselho de Administração

\footnotetext{
${ }^{37}$ O governo de Margareth Thatcher foi forte propagandista da economia de mercado e do Estado mínimo, como se observa em Grimstone (1988): "Quando Margareth Thatcher foi eleita em 1979 seu governo partiu do princípio de que nenhum mercado burocrático poderia jamais ser tão efetivo quanto o mercado real, uma vez que este apresentasse eficiência crescente. Considerou-se que a única forma - a longo prazo - de melhorar a eficiência das empresas estatizadas seria submete-las às exigências do mercado: privatização, desregulamentação, redução do monopólio e competição elevada. É importante ressaltar que, em seus primórdios, a força propulsora do programa foi basicamente econômica e direcionada a uma crescente eficiência" (p. 77).

${ }^{38}$ Até 1979 , cerca de $35 \%$ da população, na Grã-Bretanha, residia em imóveis de propriedade do Estado. Pirie (1988) argumenta que o "mercado habitacional foi distorcido pelo controle de aluguéis, estabilidade total do inquilino e habitação estatal subsidiada." (p. 19). Os imóveis públicos foram, então, vendidos com preços reduzidos, conforme o tempo de permanência dos inquilinos - com o mínimo de dois anos de locação do imóvel, o inquilino obtinha desconto de 20\%; para os inquilinos cujo tempo de permanência alcançava 20 anos ou era superior a esse tempo, o desconto era maior: alcançava $50 \%$. Esta foi a fórmula do governo para alcançar o maior número de pessoas que substituíssem o aluguel subsidiado pelo Estado pela casa própria.

39 "É interessante notar que estas empresas eram estatais porque a iniciativa privada recusava empreendimentos pesados e de risco, inovações de futuro duvidoso ou de longa e cara maturação ou porque certos empreendimentos estavam ligados à segurança nacional (pesquisa e desenvolvimento de armamentos, petróleo), ou tinham objetivos sociais ou constituíam-se em monopólios, ou porque o Estado absorvia as empresas falidas..." (Ribeiro, 1997, p. 101).

40 “O programa (...) recebeu tamanho impulso que uma privatização importante é [era] realizada a cada três ou quatro meses" (Pirie e Young, 1988, p. 35) .
} 
privado, cujo poder de seus membros, "no topo de uma grande indústria estatal", foi substituído pela posição de "administradores de uma lucrativa empresa privada". Ao mesmo tempo, aos trabalhadores foram oferecidas ações da empresa a preços atraentes em troca da segurança destes como funcionários de uma empresa estatal (Pirie, p. 17). As ações também foram oferecidas ao público, com a oferta de reduções nas contas telefônicas pelo prazo de três anos. Aproximadamente 2 milhões de pessoas adquiriram ações da British Telecom.

A privatização da British Telecom previu cláusulas de contenção de taxas e cobranças abusivas, com os aumentos ajustados aos índices inflacionários, além da obrigatoriedade da manutenção de uma quantidade mínima de telefones públicos nas áreas rurais, em uma tentativa de contemplar as reivindicações dos setores atingidos pela privatização. Não houve, no caso da privatização da British Telecom e da British Gas, qualquer tentativa de dividir as empresas e dessa forma privatizar suas partes separadamente ${ }^{41}$. Tentou-se contemplar as reivindicações dos setores sociais preocupados com a divisão das duas empresas, pois o risco de queda da qualidade dos serviços, com uma possível divisão de ambas as empresas, era uma preocupação maior que a própria privatização (Pirie, 1988, p. 18).

No começo do processo de privatizações, as empresas foram saneadas pelo Estado britânico, o que melhorou a rentabilidade das mesmas. Também houve desregulamentações e "flexibilizações" nas relações de trabalho, impondo derrotas aos sindicatos e aos movimentos dos trabalhadores. A partir das condições criadas pelo Estado, iniciou-se propriamente o processo de privatização na Grã-Bretanha, com "redução tributária e subsídios encobertos para viabilizar a rentabilidade das empresas vendidas". Muitas dessas empresas foram vendidas - parcial ou totalmente - a grandes grupos monopolistas e para empresas estrangeiras. Os efeitos colaterais do processo de privatizações na Grã-Bretanha, em oposição às análises que indicam seu virtual sucesso, foram causados pelos desequilíbrios sociais e regionais decorrentes da magnitude dos serviços privatizados, desindustrialização de algumas áreas e da "atrofia de certos ramos da economia." O desemprego expandiu-se, prejudicou uma parcela da população e a estabilidade da sociedade no longo prazo (Ribeiro, 1997, p. 100101). Como exemplo das consequiências, pode-se mencionar as cifras do setor minerador, no período compreendido entre fevereiro de 1984 e novembro de 1986, quando cerca de "54

41 "O fato é que qualquer tentativa de dividir a British Telecom ou a British Gás e privatiza-las em pedaços competidores teria falhado. A oposição da direção e da força de trabalho e o susto do público pelo temor da qualidade de seus serviços teria frustrado a proposta de maneira tão certa quanto foi a tentativa de vender as lojas de utensílios a gás." (Pirie, 1988, p. 18). 
minas foram fechadas e o número de empregados reduzido em 61.659” (Madsen e Pirie, p. 43).

A sociedade amortizou os custos da "liquidação do patrimônio público", pois no longo prazo o Estado perdeu fontes de renda, ainda que inicialmente os bilhões de libras das privatizações tenham servido como uma forma de equilíbrio orçamentário. Ainda assim, a sociedade legitimou o processo de privatização, no início, por causa dos ganhos especulativos dos pequenos compradores com a revenda das ações para o capital financeiro (Ribeiro, p. 102).

Com o objetivo de enfrentar o controle majoritário das empresas privatizadas pelo capital externo, foi criado um mecanismo (ação "golden share") que garantiria a participação do governo no conselho de administração das empresas, medida que não evitou a aquisição de parte da British Petroleum por uma empresa do Kuwait e da empresa do setor de serviços de água, por capitais franceses, que passaram a monopolizar esses serviços (Ribeiro, p. 102-103).

Com a crise resultante da quebra da bolsa em 1987, o Estado foi obrigado a manter uma série de estímulos na economia, através de subsídios ou através de encomendas para que algumas empresas não perdessem a sua rentabilidade. Diante da gravidade das circunstâncias, o Estado foi obrigado a recomprar ações de algumas empresas privatizadas (Ribeiro, p. 103).

Outro caso polêmico de privatização foi o da Eastern, empresa do setor de energia elétrica privatizada em março de 1990. A polêmica ocorreu por conta da oferta de aquisição realizada pela empresa anglo-americana Hanson, em 1995, por US\$ 4 bilhões, valor quatro vezes superior ao da privatização de 1990. Para setores ligados ao Partido Trabalhista, era inadmissível que uma empresa que oferecia um serviço essencial fosse colocada como atrativo na bolsa de valores, e reivindicavam que a reestruturação do setor elétrico fosse examinada pela Comissão de Monopólios e Fusões (Monopolies and Mergers Comission), órgão subordinado ao Ministério da Indústria e Comércio. Por outro lado, o organismo de defesa dos consumidores no Reino Unido, questionou a proposta de aquisição, na medida em que o público, tanto residencial como industrial, estava pagando caro pelos serviços da empresa e era necessário que fosse feito um controle dos preços (Otávio Dias, Folha de S. Paulo, 20/08/1995).

A British Petroleum, em 1998 a quinta empresa no ranking do setor petrolífero mundial, fundiu-se em uma mega-transação com a Amoco, a décima empresa do setor, em um 
negócio orçado em aproximadamente US\$ 54 bilhões ${ }^{42}$, criando a terceira maior empresa petrolífera do mundo. Em 1999, a BP/Amoco fundiu-se com a Arco Atlantic Richfield Co. (EUA) em um negócio estipulado em US\$ 34 bilhões (vide tabelas II.5 e II.6). A transação foi significativa para o mercado de ações, em um momento de queda das ações na bolsa londrina, e serviu para recuperar o valor das ações das companhias de petróleo. As ações da BP valorizaram-se em aproximadamente $15 \%$ na Bolsa de Londres $^{43}$.

O modelo de economia praticado na Grã-Bretanha, orientou as reformas econômicas em diversos países, através de medidas de maior liberalização da economia, desregulamentação e privatização, em uma estratégia que visava a superação da crise econômica, em um país onde a rede de proteção social era assegurada aos trabalhadores pelo Estado de Bem Estar Social.

\section{II.2. Os casos do Chile, Argentina e México}

Pode-se observar, no decorrer da década de 1990, processos de abertura comercial, desregulamentações e privatizações nos mais diversos países da América Latina, com características e processos similares. Uma espécie de onda engolfou a América Latina, e todos os países do continente se entregaram ao trabalho de ampliar o grau de liberdade das empresas de capital privado, notadamente as de capital estrangeiro, enquanto encaminhavam a privatização das empresas estatais e a renúncia ao fomento e ao financiamento de ações de desenvolvimento econômico. É quando sai de cena o ideal de desenvolvimento econômico nacional dos países da periferia do sistema - os chamados países em desenvolvimento -, e conforme a nova terminologia transforman-se em "países emergentes", sob a ótica da globalização.

Nesta parte do capítulo, há uma síntese dos processos particulares do Chile, Argentina e México, cujo intuito é o de ressaltar e expor, além das semelhanças visíveis, o resultado de um projeto que procura inserir os países da região no contexto da globalização, e termina por

\footnotetext{
${ }^{42}$ Quando o negócio foi anunciado, divulgou-se o valor de US\$ 48 bilhões (Folha de S. Paulo, 12/08/1998); entretanto, o valor de mercado das companhias alcançava US\$ 110 bilhões (Gazeta Mercantil, 12/08/1998). Quando o negócio foi autorizado pela Comissão Federal de Comércio dos EUA, os valores anunciados eram da ordem de US\$ 62 bilhões (Folha de S. Paulo, 31/12/1998).

${ }^{43}$ Folha de S. Paulo, 12/08/1998.
} 
infligir maior subordinação, dependência econômica, estagnação, dificuldades e aumento da pobreza nos países da região. As experiências realizadas no México e na Argentina, inicialmente causaram certo impacto e foram consideradas vitoriosas ${ }^{44}$, tendo se iniciado após a experiência isolada com Pinochet no Chile em 1973, Salinas de Gortari no México, em 1988, Menem na Argentina e Carlos Andrés Perez na Venezuela, em 1989. Em 1990, foi a vez do Peru, com Fujimori, e do Brasil, com Collor.

O caso brasileiro pode ser acrescentado entre as experiências cujo "êxito" das medidas neoliberais conduziu a uma de suas maiores crises econômicas, ao desemprego em massa, falências e crise do setor energético, e aonde também os governantes eleitos não prometeram o que efetivamente cumpriram ${ }^{45}$.

\section{II.2.1 O caso do Chile}

O Chile, a partir de 1973 (antes, portanto, do governo Thatcher, na Grã-Bretanha), foi o precursor das reformas econômicas neoliberais na América Latina, privatizando, desregulamentando e implantando as medidas neoliberais ${ }^{46}$. Nesse país, o processo iniciou-se sob regime ditatorial, quando foi privatizada a maior parte das empresas estatais, mas manteve-se o controle acionário da Codelco e participações minoritárias em petróleo e eletricidade, setores considerados estratégicos. Assim é que, no Chile, “o setor nacionalizado da economia caiu de 45\% do PNB em 1973, para 25\% em 1978”. (Mamigonian, 1999, p. 145).

No Chile, a CORFO (Corporación de Fomento de Produción), criada em 1939, organizava o planejamento e o fomento de atividades econômicas, sendo a sua função

\footnotetext{
44 "Das quatro experiências viáveis desta década, podemos dizer que três registraram êxitos impressionantes a curto prazo - México, Argentina e Peru - e uma fracassou: Venezuela" (Anderson, 1995, p. 21). Evidentemente, o autor não podia imaginar as graves conseqüências do processo na Argentina e as crises no Brasil.

45 "Nenhum desses governantes confessou ao povo, antes de ser eleito, o que efetivamente fez depois de eleito. Menem, Carlos Andrés e Fujimori, aliás, prometeram exatamente o oposto das políticas radicalmente antipopulistas que implementaram nos anos 90" (Anderson, 1995, p. 20-21).

${ }^{46}$ Perry Anderson (1995) assinala que o modelo neoliberal inglês foi "o pioneiro e o mais puro", entretanto, ressalta ter sido o Chile, "sob a ditadura de Pinochet ... o verdadeiro pioneiro do ciclo neoliberal da história contemporânea". No Chile o programa foi implementado de maneira dura, com "desregulação, desemprego massivo, repressão sindical, redistribuição da renda em favor dos ricos, privatização de bens públicos". Esse processo teve seu início "quase um decênio antes de Thatcher, na Inglaterra", mas também foi uma experiência que, nas suas palavras, "interessou muitíssimo a certos conselheiros britânicos importantes para Thatcher, e que sempre existiram excelentes relações entre os dois regimes nos anos 80" (grifo meu) (Anderson, 1995, p. 19).
} 
principal a de desenvolver, criar e gerir empresas, apoiar e financiar as pequenas e médias empresas, capacitar mão de obra, etc.. Diversas empresas, entre as maiores do país, tinham participação acionária da CORFO (Cano, 2000, p. 300). Das 527 empresas administradas pela CORFO, em 1973, sobraram 24 companhias estatais em 1980, após as privatizações, relacionadas na sua maioria aos setores de infra-estrutura e mineração de cobre. Uma parte delas, cerca de 202 empresas, anteriormente encampadas pelo governo de Salvador Allende, retornaram aos antigos proprietários em 1974. No período 1974-1979, 120 estatais foram privatizadas, e com isso foram arrecadados cerca de US\$ 823 milhões (incluindo a venda de outros ativos e participações), valores que representaram aproximadamente " $70 \%$ do valor patrimonial desses ativos". Nesse processo, a CORFO perdeu as atribuições de planejamento e fomento, tornando-se, apenas e tão somente, uma "administradora de privatizações" (Cano, 2000, p. 312).

O golpe militar, em 1973, deflagrou as reformas. Grande parte das privatizações foi realizada com financiamento externo, em benefício, portanto, de "novos grupos emergentes nacionais", e assim alteraram "parte da estrutura social do poder econômico". Ressalte-se que os recursos entrantes serviram para "atenuar parte do desequilíbrio fiscal e da dívida externa". Posteriormente, a crise da dívida "colocaria de novo o Estado na administração de ativos privados, via intervenção no sistema financeiro, em crise" (Cano, p. 313).

Aproximadamente 2000 indústrias quebraram no período 1973-1981, em conseqüência da crise e da abertura comercial (Cano, p. 318-319). Em meio à crise, nos anos de 1983 e 1984, as empresas estatizadas foram vendidas, e o valor arrecadado alcançou 6\% do PIB médio relativo ao biênio. Em 1985 e 1989, foram privatizadas algumas empresas da CORFO, pertencentes, principalmente, aos setores de siderurgia, química, alimentos, entre outros, e os bancos também foram reprivatizados, assim como empresas prestadoras de serviços (transportes, eletricidade, comunicações). O resultado dessas privatizações alcançou US\$ 1,4 bilhão, cerca de 1\% do PIB médio anual do período (Cano, p. 323-324), mas assim como na Argentina e também em outros países, a dívida externa chilena, de US\$ 5 bilhões em 1975, alcançou US\$ 18,4 bilhões em 1985 (Mamigonian, 1999).

Entre 1990-1996 foram vendidas 14 instituições, dentre elas a Zona Franca de Iquique, outras empresas de eletricidade, mineração, transportes e comunicações, apurando o governo cerca de US\$ 1,1 bilhão (Cano, p. 332). 
Até 1997 a companhia mineradora CODELCO ainda se encontrava sob propriedade estatal, assim como empresas ligadas à infra-estrutura e aos setores de comunicações e petróleo (Cano, p. 332). Apenas para se ter uma idéia da importância da CODELCO, afirmase que essa empresa contribuiu, em 1996, com US\$ 870 milhões em impostos, cerca de 1,2\% do PIB ou 57\% da contribuição de todas as empresas privadas chilenas (Cano, p. 334).

Tradicionais investidores no Chile - os Estados Unidos e o Canadá - com participações respectivas de $41 \%$ e $18 \%$, no período 1990-1996, principalmente no setor de mineração (47\%), foram superados em 1997 por investimentos europeus, Espanha à frente com 31\% (aos Estados Unidos coube 18\%). Em 1997, ao setor de mineração coube 33\% dos IEDs, ao setor de eletricidade, gás e água, 27\%, e outros serviços (26\%). Nesse país, as 20 maiores empresas estrangeiras (em vendas) atuam nos setores de mineração, comércio, energia, telecomunicações e agroindústria. As principais estratégias dessas empresas referemse, no geral, a:

1. garantir o acesso a matérias primas: caso das empresas La Escondida (BHP/ Austrália, RTZ/Reino Unido e Jeco/Japão); Minera El Abra (Cyprus Amax/ EUA); Cia. Minera Candelária (Phelps Dodge/EUA e Sumitomo/Japão); Disputada de Las Condes (Exxon Corporation/EUA); Mantos Brancos (Mininco/Luxemburgo); Copec (Carter Holt Harvey/Nova Zelândia).

2. garantir o acesso ao setor de serviços: em energia, a Enersis (Endesa/Espanha); no comércio, Supermercados Santa Isabel (Royal Ahold/Holanda); no setor bancário, Banco Santander (Espanha).

Ademais, no Chile, a tendência era a da crescente participação de firmas estrangeiras na aquisição de companhias locais, principalmente empresas líderes em seus setores. Foram adquiridas: Prosan (US\$ 375 milhões) pela Procter \& Gamble; participação acionária do BHIF pelo BBV (US\$ 350 milhões); e a Dos en Uno pela Arcor, por US\$ 200 milhões (Cepal, Informe 1998).

\section{II.2.2 O caso da Argentina}

Durante a década de 1990, as estratégias empresariais foram redefinidas na Argentina com processos de abertura comercial, estabilização e alterações na concorrência provocadas 
por esses processos. As empresas buscaram maior racionalidade das suas estruturas, o que resultou em diminuição da oferta de emprego, e a "adoção de novas estratégias de comercialização e distribuição". As maiores empresas privadas e principalmente as filiais de empresas transnacionais foram as que puderam realizar essa racionalização em melhores condições (Bonelli, 2000a, p. 66).

Na Argentina, entre 1990-1994, as receitas provenientes de privatizações e concessões de serviços públicos alcançaram US\$ 15,4 bilhões, ou seja, $82 \%$ do total referente ao período 1990-1997. Os valores referentes ao período 1990-1994 representaram cerca de 2\% do PIB, em média, em cada um desses anos. De 1994 a 1997, este número cai para 0,5\% do PIB. O total de privatizações do período alcançou US\$ 18,7 bilhões. Nesse país, as privatizações foram cruciais para o processo de abertura, propiciando o acesso do país ao crédito internacional e a renegociação da sua dívida externa. As primeiras fábricas vendidas foram aquelas cuja operação ficava a cargo das Forças Armadas. Em seguida foram privatizadas as empresas de telecomunicações, de aviação comercial e de eletricidade (geração, transmissão e distribuição de energia); empresas de transporte e distribuição de gás; linhas de metrô e um terço da rede rodoviária; portos e elevadores portuários; duas ferrovias, 33 aeroportos, oitocentos imóveis, siderúrgicas, empresas de petróleo e gás (refino, oleodutos e frota, além de concessões de áreas para sua extração); frigorífico, hipódromo e ações de várias empresas. No ano de 1998 havia por concluir a venda de ações remanescentes da YPF, dos correios, de centrais nucleares e o Banco Hipotecário Nacional. Algumas privatizações resultaram problemáticas, como por exemplo a das Aerolíneas Argentinas, por conta da debilidade financeira dos compradores. Nesse caso, o governo argentino readquiriu 30\% das ações e houve redução de $10 \%$ do número de vôos e de escalas nacionais. Também a concessão das rodovias resultou problemática pelo grande número de pedágios e os altos preços das tarifas. O Poder Judiciário argentino terminou por suspender as privatizações dos aeroportos por irregularidades e falhas processuais (Cano, p. 125-126).

As críticas ao processo de privatizações na Argentina relacionaram-se à "pressa" na sua execução. Outros problemas decorrentes do processo relacionavam-se à precariedade das normas regulatórias, ao aumento dos preços e das tarifas públicas, muitos deles ocorridos antes das privatizações e a subavaliação dos ativos. Como decorrência do processo, ficou patente o "aumento da oligopolização-monopolização e da concentração-centralização privada do capital”, em contraposição aos argumentos de defesa do processo enquanto 
causador de maior "concorrência no mercado". Foram percebidos, no longo prazo, efeitos negativos no Balanço de Pagamentos, pois não houve um "efeito positivo sobre a dívida externa"; ao contrário, este revelou-se um equívoco e aumentou "a incerteza quanto aos futuros investimentos dos setores privatizados e seu nexo com a estrutura produtiva e o investimento do país" (Cano, p. 126-127).

As privatizações do período 1989-1996 não contribuíram para a diminuição da dívida externa argentina, pois a dívida do governo aumentou em US\$ 17,6 bilhões e a do setor privado em US\$ 16,8 bilhões, tendo aumentado cerca de 53\% no período. No período 19901994, aproximadamente $50 \%$ dos recursos externos entrantes como investimento direto foram para as privatizações, com o capital estrangeiro respondendo por $63 \%$ delas. Os maiores investidores, no caso, foram a Espanha, com 18\%, e os EUA com 16\%. A maior parte dos recursos externos, cerca de 98\%, foram para os setores: eletricidade, gás, petróleo, telecomunicações, finanças e transporte aéreo, geradores de poucas divisas, mas que, doravante possibilitariam o envio de "crescentes remessas de lucros" ao exterior (Cano, p. 128-129). Houve melhoria do resultado financeiro do governo "graças ao câmbio, à drástica queda da inflação, às privatizações e, notadamente ao forte crescimento do PIB (27\% acumulado em 1991-1993), que aumentou a arrecadação do IVA”, mas com a crise em 1995, houve aumento das incertezas e também dos depósitos bancários em dólar (idem, p. 139-141) 47. Entretanto, a crise que tomou o país demonstrou seus efeitos com o desaparecimento de 27 bancos em apenas dois meses. A maioria das instituições que restaram não estava segura da sua solvência48. A reforma do sistema financeiro iniciou-se pela absorção dos pequenos bancos e a realização de 35 fusões. O ano terminaria com a redução de 169 para 129 bancos na Argentina. Seis bancos foram privatizados e sete eliminados. Na Argentina o que se denominava como fusão seria mais bem caracterizado "como um processo de absorção estimulado pelo Banco Central"49.

A partir de 1995 ampliaram-se os problemas no país, em um quadro de aumento tanto dos juros internos como externos, com a recessão e o desemprego pressionando o déficit

\footnotetext{
${ }^{47}$ (...) em 1995 a crise exigiu profunda reformulação nas bases antes estabelecidas ao sistema financeiro, suspendendo temporariamente a independência do Banco Central e o papel das forças de mercado: intervenção no mercado, créditos emergenciais e, em seguida, uma deliberada política de financiamento para privatizações de bancos provinciais, fusões e vendas de bancos - principalmente para o capital estrangeiro -, o que, de um lado, aumentou fortemente a concentração bancária e financeira, e de outro, contraiu acentuadamente as possibilidades de financiamento a cooperativas, pequenas e médias empresas e às economias regionais (Cano, 2000, p. 141).

${ }^{48}$ José Roberto Campos, Folha de S. Paulo, 12/03/1995, Caderno 2, p. 9.

${ }^{49}$ Denise Chrispim Marin, Folha de S. Paulo, 05/11/1995, Caderno 2, p. 10.
} 
público, pois mesmo após o processo de privatização, tornava-se mais difícil sanear o déficit. A dívida externa da Argentina acresceu de US\$ 62 bilhões em 1990 para US\$ 118 bilhões em 1998. No decorrer do mesmo período, o investimento direto acumulou US\$ 32 bilhões, sendo que, desse total, aproximadamente US\$ 11 bilhões foram investimentos no processo de privatizações. No período 1990-1996, a remessa de lucros triplicou, e totalizou US\$ 9 bilhões. No período 1992-1996, de US\$ 16,3 bilhões de investimento direto acumulado, 55\% significaram transferência de propriedade (31\% públicas e 24\% privadas) (Cano, p. 142-143).

Uma das conseqüências da abertura comercial e das privatizações realizadas na Argentina foi a ampliação da desnacionalização, com o aumento da participação das empresas de capital estrangeiro, durante 1990-1995, de 37,5\% para 50,2\%, nas vendas das dez maiores de todos os setores da economia, e aumentou entre as cem maiores de 36,4\% para 54,1\%. Além da desnacionalização houve o aumento da concentração por parte das empresas de capital estrangeiro, com casos exemplares como a entrada da Nabisco e da Parmalat no setor de alimentos, e no setor automotivo, com a entrada da Toyota e o retorno ao mercado da GM e da Chrysler, além da ampliação da participação da Ford e da Volkswagen (Cano, p. 149).

A comparação entre Argentina e Chile, países relacionados ao bloco do Mercosul, pode ser enriquecida com os dados apresentados por Bonelli (2000b), relativos a fusões e aquisições no decorrer de 1992 a 1998, mencionados na tabela II.1, onde encontramos os totais referentes a alguns dos setores envolvidos nos negócios realizados no período.

Através da tabela II.1, é possível comparar as transações realizadas no período 19921998, e os setores mais atingidos. Pode-se notar a quantidade de negócios, em primeiro lugar, no setor financeiro (89 transações), seguido pelo setor químico (71), alimentos (66) e serviços (55). É necessário ressalvar que os números apresentados devem ser entendidos como “aproximados", pois não chegam a representar uma estatística do período. Para o caso do Brasil, os números divergem dos dados da KPMG, que aponta para o período 741 transações, o que pode ser explicado pela ausência, na tabela II.1, de alguns setores pesquisados pela KPMG Corporate Finance. Por outro lado, deve-se registrar que a maior quantidade de transações ocorreu no Brasil, pois a expansão das transações na Argentina já havia arrefecido, e o grande número de incorporações bancárias reflete a crise naquele país e o início do processo de privatizações no setor bancário e a abertura dos bancos ao capital estrangeiro no Brasil. 
Tabela II.1:

Número de fusões e aquisições nos países do Mercosul entre 1992 e 1998*

\begin{tabular}{|c|c|c|c|c|c|c|c|}
\hline Setor & Argentina & Brasil & Paraguai & Uruguai & Bolívia & Chile & Total \\
\hline Aeroportos & 1 & 0 & 0 & 0 & 0 & 0 & 1 \\
\hline Agropecuária & 4 & 0 & 0 & 0 & 0 & 1 & 5 \\
\hline Alimentos & 31 & 32 & 0 & 0 & 0 & 3 & 66 \\
\hline Atacadista & 2 & 1 & 0 & 0 & 0 & 0 & 3 \\
\hline Automobilístico & 11 & 29 & 0 & 0 & 0 & 0 & 40 \\
\hline Bebidas & 20 & 5 & 0 & 0 & 2 & 3 & 30 \\
\hline Comunicações & 31 & 4 & 0 & 0 & 0 & 0 & 36 \\
\hline Distribuição de Petróleo e Gás & 6 & 1 & 0 & 0 & 0 & 2 & 9 \\
\hline Energia Elétrica & 5 & 2 & 0 & 0 & 0 & 4 & 11 \\
\hline Farmacêutico & 9 & 4 & 0 & 0 & 0 & 1 & 14 \\
\hline Financeiro & 23 & 60 & 0 & 1 & 4 & 2 & 89 \\
\hline Gráfica e Editorial & 7 & 4 & 0 & 1 & 0 & 0 & 11 \\
\hline Higiene e Limpeza & 2 & 0 & 0 & 0 & 0 & 0 & 2 \\
\hline Madeira & 1 & 0 & 0 & 0 & 0 & 1 & 2 \\
\hline Material Elétrico e Comunicação & 2 & 24 & 0 & 0 & 0 & & 26 \\
\hline Metalurgia & 7 & 27 & 1 & 0 & 0 & 0 & 34 \\
\hline Mineração & 2 & 4 & 0 & 0 & 0 & 2 & 9 \\
\hline Minerais não-metálicos & 14 & 6 & 0 & 0 & 1 & 0 & 21 \\
\hline Papel e Celulose & 11 & 6 & 0 & 1 & 0 & 1 & 19 \\
\hline Portos & 1 & 0 & 0 & 0 & 0 & 0 & 1 \\
\hline Previdência & 1 & 0 & 0 & 0 & 0 & 0 & 1 \\
\hline Químico & 26 & 40 & 0 & 0 & 0 & 3 & 71 \\
\hline Seguros & 5 & 7 & 0 & 0 & 0 & 7 & 19 \\
\hline Serviços & 22 & 31 & 1 & 1 & 0 & 2 & 55 \\
\hline Têxtil & 6 & 0 & 0 & 0 & 0 & 0 & 7 \\
\hline Transportes & 1 & 2 & 0 & 0 & 0 & 0 & 3 \\
\hline Transporte (aviação) & 1 & 7 & 1 & 0 & 0 & 3 & 12 \\
\hline Transporte (Ferroviário) & 2 & 0 & 0 & 0 & 0 & 0 & 2 \\
\hline Transporte (naval) & 0 & 3 & 0 & 0 & 0 & 0 & 3 \\
\hline Varejo & 17 & 9 & 0 & 0 & 0 & 2 & 28 \\
\hline Distribuição de água e esgoto & 0 & 0 & 0 & 0 & 0 & 1 & 1 \\
\hline Outros & 0 & 15 & 0 & 0 & 0 & 0 & 15 \\
\hline Total & 271 & 323 & $\mathbf{0 3}$ & 04 & 07 & 38 & 646 \\
\hline
\end{tabular}

Fontes: América Economia, KPMG e Kulfa, Hecker e Kaminski (1998) apud Bonelli (2000b)

* Para os anos de 1992 a 1995 os dados obtidos referem-se apenas ao Brasil e à Argentina.

Na tabela II.2, os dados relativos às privatizações na Argentina, no período compreendido entre 1990 e junho de 1998, indicam a ampliação da participação estrangeira em setores importantes, se considerarmos, como é preciso, a participação dos consórcios, principalmente consórcios mistos e empresas estrangeiras nas transações. Essa participação não é irrelevante, e aponta para uma grande participação estrangeira nos setores de energia elétrica, financeiro, gás, petróleo, químico, etc..

Ainda que as análises possam limitar-se a dados parciais, pois nem todos os valores ou negócios são divulgados, eles apontam tendência significativa do aumento da participação estrangeira nas economias dos países latino-americanos.

Para o caso argentino, é evidente o aumento da participação estrangeira, na análise da estrutura dos investimentos diretos, conforme a tabela II.3, onde é possível verificar o considerável aumento dessa participação, principalmente nas fusões e aquisições. Aliás, o 
total da participação estrangeira neste indicador é bastante superior ao total da participação das empresas nacionais.

Cumpre ressaltar que, pela sua importância e conforme indicado, os dados apresentados nas tabelas II.1, II.2 e II.3 foram retirados de Bonelli (2000b).

\section{Tabela II.2}

Privatizações na Argentina, 1990 a Junho/1998, Número de Transações por Setor segundo Adquirente

\begin{tabular}{|c|c|c|c|}
\hline Setor & Tipo de Comprador & Número de Operações & Valor em US\$ Milhões \\
\hline \multirow[t]{3}{*}{ Alimentos } & Empresa Argentina & 3 & 7,50 \\
\hline & Consórcio Nacional & 1 & 1,90 \\
\hline & Consórcio Misto (a) & 1 & 2,00 \\
\hline \multirow[t]{2}{*}{ Bebidas } & Empresa Argentina & 1 & 11,50 \\
\hline & Consórcio Nacional & 1 & 2,20 \\
\hline Comunicação & Empresa Argentina & 6 & $14,00 * * *$ \\
\hline \multirow[t]{6}{*}{ Energia Elétrica } & Empresa Argentina & 6 & 623,90 \\
\hline & Consórcio Nacional & 8 & 58,50 \\
\hline & Consórcio Misto (a) & 11 & 1377,10 \\
\hline & Consórcio Misto-Mercosul (b) & 2 & 734,90 \\
\hline & Consórcio Mercosul (c) & 1 & 85,70 \\
\hline & Empresa Estrangeira (d) & 3 & 539,20 \\
\hline \multirow[t]{3}{*}{ Financeiro } & Empresa Argentina & 3 & $1,20 *$ \\
\hline & Consórcio Misto (a) & 1 & 86,30 \\
\hline & Empresa Estrangeira (d) & 1 & 118,00 \\
\hline \multirow[t]{4}{*}{ Gás } & Consórcio Nacional & 1 & n.d. \\
\hline & Consórcio Misto (a) & 9 & $1517,70 * *$ \\
\hline & Consórcio Misto-Mercosul (b) & 1 & n.d. \\
\hline & Consórcio Mercosul (c) & 1 & 72,00 \\
\hline \multirow[t]{3}{*}{ Metalurgia } & Empresa Argentina & 2 & 11,30 \\
\hline & Consórcio Nacional & 1 & 148,70 \\
\hline & Consórcio Misto (a) & 1 & 33,00 \\
\hline \multirow[t]{3}{*}{ Petróleo } & Consórcio Nacional & 6 & 605,80 \\
\hline & Consórcio Misto (a) & 8 & 937,50 \\
\hline & Consórcio Misto-Mercosul (b) & 1 & 143,70 \\
\hline \multirow[t]{3}{*}{ Químico } & Empresa Argentina & 12 & 165,50 \\
\hline & Consórcio Nacional & 2 & 141,10 \\
\hline & Consórcio Misto (a) & 2 & 358,50 \\
\hline \multirow[t]{3}{*}{ Serviços } & Empresa Argentina & 3 & $107,00 * * *$ \\
\hline & Consórcio Nacional & 6 & $63,00 *$ \\
\hline & Consórcio Misto (a) & 2 & $12,60 *$ \\
\hline Telecomunicações & Consórcio Misto (a) & 2 & 1471,00 \\
\hline \multirow[t]{3}{*}{ Transportes } & Empresa Argentina & 3 & $17,40 * * *$ \\
\hline & Consórcio Nacional & 10 & n.d. \\
\hline & Consórcio Misto (a) & 5 & $692,70 * * *$ \\
\hline
\end{tabular}

Fonte: América Economia; KPMG e Kulfa, Hecker e Kaminski (1998) apud Bonelli (2000b)

- (a) Consórcio Misto: empresas argentinas e empresas não pertencentes ao bloco Mercosul e Associados;

- (b) Consórcio Misto-Mercosul: empresas argentinas elou pertencentes ao bloco e empresas não pertencentes ao bloco;

- (c) Consórcio Mercosul diz respeito apenas a empresas do Mercosul e Associados;

- (d) Empresas do Mercosul e Associados;

* Apenas divulgado o valor de uma operação.

** Apenas divulgado o valor de oito operações.

*** Apenas divulgado o valor de oito operações.

n.d. - não disponível 
Tabela II.3:

ESTRUTURA DAS INVERSÕES DIRETAS NA ARGENTINA POR ORIGEM DE CAPITAL E TIPO DE OPERAÇÃO

\begin{tabular}{lccc} 
& (Em \% e valores totais em US\$ bilhões) & \\
\hline & $1990 / 1998$ & $1999 / 2000$ & Total \\
\hline Estrangeira & $\mathbf{6 4 , 2}$ & $\mathbf{6 3 , 1}$ & $\mathbf{6 3 , 9}$ \\
Compras & 42,3 & 4,1 & 31,2 \\
F\&A & 30,3 & 3,6 & 22,5 \\
Privatização & 12,0 & 0,4 & 8,7 \\
Formação de capital & 57,7 & 95,9 & 68,8 \\
& 19,8 & 48,1 & 27,9 \\
Greenfield & & & \\
Ampliação & 38,0 & 47,9 & 40,8 \\
Nacional & $\mathbf{3 4 , 3}$ & $\mathbf{2 3 , 3}$ & $\mathbf{3 1 , 1}$ \\
Compras & 21,8 & 3,3 & 17,7 \\
F\&A & 9,7 & 3,3 & 8,3 \\
$\quad$ Privatização & 12,1 & 0,0 & 9,5 \\
Formação de capital & 78,2 & 96,7 & 82,3 \\
Greenfield & 17,8 & 22,0 & 18,7 \\
$\quad$ Ampliação & & & \\
Indeterminado & 60,4 & 74,7 & 63,5 \\
Total & 1,6 & 13,5 & 5,1 \\
Valor (US\$ bilhões) & 100,0 & 100,0 & 100,0 \\
\hline
\end{tabular}

Fonte: Bonelli, 2000b, p. 17.

Na Argentina, no período 1992-1996, coube aos Estados Unidos a maior parte dos investimentos estrangeiros diretos (33\%), o que se repetiu em 1997 (20\%). Entretanto, coube à Espanha, no mesmo período, 5\% e 40\%, respectivamente. Os investimentos estrangeiros voltaram-se, nesse país, para os setores financeiros, com a entrada dos bancos espanhóis BBV e BSCH e do banco britânico HSBC, adquirindo bancos locais (Cepal, Informe 1998).

No setor de telecomunicações, ocorreu forte concentração, com aliança entre Telefônica de Espanha e CEI-Citicorp. No comércio, entraram: Carrefour, Royal Ahold, Exxel Group, Paulmann, Cassino, Wal-Mart. No setor de Petróleo e Gás, entraram: Repsol, Enron, British Gas, Gas Natural e Camuzzi, além de ESSO e Shell (Cepal, Informe 1998).

Ao final da década, a desnacionalização não havia atingido apenas o setor estatal da economia, mas também o setor privado. Empresas e marcas símbolos da indústria foram transferidas para o controle de empresas estrangeiras, a maioria do setor de alimentos: em 1994 a fábrica de biscoitos Bagley foi adquirida pela Danone, por US\$ 240 milhões; sua principal concorrente, Terrabusi, passou para a Nabisco no mesmo ano; em 1995 foi a vez da Stani ser adquirida pela Cadbury Schweppes; em 1998, a fábrica de alfajores Havanna foi 
adquirida pelo fundo de investimentos americano Exxel Group, por US\$ 85 milhões, que adquiriu também uma tradicional rede de sorveterias (Freddo), por US\$ 82 milhões; a Mantecol (doces), foi adquirida pela Cadbury Schweppes, por US\$ 25 milhões, em 2000. Restavam, então, três grandes grupos nacionais: Arcor (alimentos), com faturamento de US\$ 1,15 bilhão (1999); o grupo Socma (família Macri), com faturamento de US\$ 1,4 bilhão (1999), e a Perez Companc, que faturou US\$ 2,2 bilhões (1999) ${ }^{50}$. Em 2002, a Petrobrás assumiu o controle acionário da Pecom Energia, vendida pelo grupo Perez Companc, por US\$ 1,027 bilhão ${ }^{51}$.

\section{II.2.3 O caso do México}

O México também possuía uma instituição voltada para promover e financiar o desenvolvimento, criada em 1934, denominada Nacional Financiera. No final da década de 1940, o Estado possuía 36 empresas (Cano, p. 403).

O processo de desestatização e privatizações no México deu-se também a partir dos anos 1980, quando foram liquidados ou extintos diversos órgãos e empresas (Cano, p. 422). No período 1986-1988, foram vendidas participações acionárias, empresas pequenas e médias, além de ocorrer a fusão de empresas ou órgãos do governo52.

Na década seguinte, a condução do processo de privatizações foi gradual, pelas dificuldades nas negociações realizadas entre os trabalhadores, os sindicatos e o Congresso. A maior parte das privatizações ocorreu nos governos de Salinas e Zedillo, quando foram privatizadas empresas maiores, mais complexas e estratégicas, relacionadas aos setores de infra-estrutura, financeiro, siderúrgico, petroquímico, telecomunicações, transportes, estradas, etc.. No caso do setor de telecomunicações, a participação máxima permitida para o capital estrangeiro não poderia exceder $49 \%$, exceto para telefonia celular. Os recebimentos resultantes das privatizações das estatais são estimados em US\$ 25 bilhões, no período 1989-

\footnotetext{
${ }^{50}$ Folha de S. Paulo, 15/01/2001.

${ }^{51}$ Gazeta Mercantil, 10/10/2002.

${ }^{52}$ Em 1982 existiam 1.155 entidades estatais: 102 órgãos descentralizados, 744 empresas com participação majoritária, 78 com minoritária e 231 fundos públicos específicos. Ao final de 1988, haviam sido vendidas todas as participações minoritárias e, com as demais liquidações (277), extinções (145), vendas (238), fusões (85) e transferências de trinta entidades para outras esferas de governo, restavam ainda 412 entidades (82 órgãos, 252 empresas e 71 fundos) para o período seguinte (Cano, 2000, p. 422).
} 
1994, ou seja, aproximadamente 8,3\% do PIB médio anual do período. Com a crise econômica, no biênio 1995-1996 retornaram para o Estado 23 das 52 rodovias privatizadas, quando os preços dos pedágios sofreram redução, o que acarretou um prejuízo para o Estado da ordem de US\$ 2,3 bilhões (Cano, p. 435-436).

O governo esperava arrecadar cerca de US\$ 14 bilhões com diversas novas privatizações e concessões no período 1997-1999. Foram contestadas as transações no setor petrolífero, e na sequiência de diversas negociações, foram definidas as alterações, com a divisão da Pemex em quatro empresas, etc.. O México não havia privatizado a produção de petróleo, mas na crise de 1995 os EUA exigiram a privatização do setor como garantia para empréstimos (Cano, p. 436-437).

No México, cerca de $60 \%$ dos investimentos estrangeiros diretos originaram-se dos Estados Unidos, apenas no período 1994-1998. Outros países apresentam investimentos bem inferiores, como é o caso do Reino Unido e Países Baixos, com 7\% cada um, Alemanha e Canadá, com 4\% cada um, Japão, com 3\%, Espanha com 2\%, etc.. A distribuição setorial dos investimentos, no mesmo período, apresenta a maior parcela no setor de alimentos, bebidas e fumo (com 16\%), seguido por equipamentos eletrônicos (13\%), comércio (12\%), outras manufaturas $(11 \%)$, produtos químicos $(9 \%)$, veículos motorizados (9\%), etc.. (Cepal, Informe 2000).

A TELMEX, companhia telefônica privatizada em 1990 - em um consórcio entre o Grupo Carso, France Telecom e SBC, com o controle acionário pelos estrangeiros de 49\% obteve exclusividade sobre o mercado até o final de 1996. Com a abertura do mercado de telefonia local, a TELMEX passou a competir com AT\&T e MCI-WorldCom (Cepal, Informe 2000).

A abertura do sistema financeiro mexicano ocorreu em função da crise de 1994, e no início de 1999 já era permitido às instituições estrangeiras controlar 100\% dos bancos locais (até 1996 só existia uma instituição estrangeira operando no país, o Citibank). Os bancos espanhóis BSCH e BBVA e os bancos canadenses Nova Scotia e Montreal passaram a operar no país, disputando um mercado até então dominado pelos dois maiores bancos mexicanos: Banamex e Bancomer. Posteriormente, o J. P. Morgan e o Citibank expandiram as suas operações no país (Cepal, Informe 2000). 


\section{II.2.4 Características das transações no mundo}

$\mathrm{Na}$ década de 1980 as características preponderantes das fusões e aquisições foram daquelas operações definidas como "takeovers" ou aquisições hostis, ou seja, aquisições acionárias sem qualquer negociação entre as partes, característica "de ação unilateral por parte de um agente econômico" (Gonçalves, 2000, p. 86). Na década de 1990, ao contrário, as transações caracterizaram-se por uma ação empresarial de natureza estratégica, mais preocupada com o longo prazo. A diferença principal entre os dois tipos de negócios refere-se a sua forma de pagamento, realizados à vista nos anos 1980, enquanto nos anos 1990 foram realizados, principalmente, através da troca de ações. Verifica-se, no período mais recente, o retorno de práticas de aquisições hostis, principalmente na Europa, como a transação da Olivetti para a compra de ações da Telecom Itália, cujo valor alcançou US\$ 65 bilhões.

A comparação entre as décadas de 1980 e 1990 no mundo é importante, pois ao assinalar a ocorrência de diversas transações, retira o caráter de novidade conferido a elas atualmente. Um elemento mais recente é a intensificação de megafusões, transações gigantescas que apontam para o aumento da centralização de capitais anteriormente referido, sobretudo transações com participação estrangeira, - principalmente na América Latina, associadas ao processo de privatização e desnacionalização de empresas.

Um exemplo importante é dado pela economia do Japão, que dificulta principalmente as fusões e aquisições envolvendo não-residentes, através da imposição de barreiras. Gonçalves atribui aos conglomerados japoneses a preponderância no sistema econômico empresarial do país, sem mencionar o papel do Estado japonês, mas ressalta a ampliação da crise econômica como motivação para o aumento do número de fusões e aquisições a partir de 1996. No Japão, foram realizadas 908 transações em 1998, o que representa um crescimento de 35\% nos negócios em relação ao ano anterior, valor superior ao das operações ocorridas em 1993 (Gonçalves, p. 86).

As fusões e aquisições dos anos 1990 caracterizam-se pelo aumento das operações transfronteiriças (também denominadas cross-border), ou seja, transações que envolvem grupos ou empresas de países diferentes, ou casos de negócios realizados entre residentes e não-residentes. Estima-se um aumento de aproximadamente US\$ 162 bilhões em 1993, para cerca de US\$ 342 bilhões em 1997, e US\$ 544 bilhões em 1998, "valores que representam um 
crescimento médio anual de 29,9\%" (Gonçalves, p. 87). Os valores referentes ao biênio 1997 98, de fusões transfronteiriças alcançam US\$ 886 bilhões, com os Estados Unidos respondendo por $40 \%$ das vendas, União Européia 30\% e Japão 0,9\%. As parcelas respectivas da participação no PIB mundial são: Estados Unidos e União Européia: 20\% e Japão 8\% (Gonçalves, p. 87).

Pelo lado da compra de empresas, Gonçalves apresenta os seguintes dados: Estados Unidos: 23\%; União Européia: 51\% e Japão: 2\%. A participação dos Estados Unidos corresponde à sua parcela na renda mundial. A participação da União Européia é mais elevada nas compras. A participação do Japão é maior nas operações de compra do que nas operações de vendas. Entretanto, tais dados, conforme Gonçalves (2000), devem ser analisados cautelosamente, pois podem ocorrer mudanças nas posições de um ano para o outro (p. 87).

Em relação à distribuição setorial, no setor primário destacam-se a mineração e a exploração de petróleo. No setor secundário, as maiores transações realizaram-se na indústria química e na indústria de alimentos, bebidas e fumo. No setor terciário destacam-se os bancos, a distribuição de eletricidade e água, a produção e distribuição de energia elétrica, gás e outras formas de energia, além do setor de seguros e telecomunicações (Gonçalves, p. 87).

Aproximadamente 2/3 das transações transfronteiriças estiveram concentrados "nos setores de infra-estrutura (água e energia), telecomunicações, finanças (bancos e seguros), petróleo, gás natural e mineração, e na indústria química", demonstrando o "avanço do processo de fusões e aquisições em escala global", inexistindo evidência de reversão futura (Gonçalves, p. 87).

\section{II.2.4.1 Possíveis contraposições ao movimento de fusões e aquisições}

Seriam quatro os possíveis fatores de contraposição ao movimento internacional de fusões e aquisições de empresas (Gonçalves, p. 87-88):

I. o aumento da taxa de desemprego na Europa (11\% em 1998) seria um fator de restrição das transações, demonstrado pela preocupação dos governos com as demissões e o desemprego causado pelas fusões e aquisições;

II. a aplicação de políticas antitruste realizadas nos Estados Unidos e na Europa, devido à “globalização", pois o atual processo de centralização e concentração de capital provoca a 
redução da concorrência, aumentando a preocupação com o abuso do poder econômico. Há uma tendência recente na Comissão Européia em não se estimular fusões cross border, também há uma certa rejeição às "aquisições hostis", como por exemplo, a intervenção do governo norte-americano, que impediu a fusão da Lockheed Martin com a Northrop Grumman;

III. o setor de tecnologia da informação, onde ocorreram várias transações, não correspondeu totalmente às expectativas, pois os negócios não redundaram em maiores benefícios;

IV. o nacionalismo seria outro fator importante na determinação do processo, enquanto uma força que orienta a condução do processo de fusões e aquisições, principalmente na Europa, onde alguns negócios não se realizaram, como no caso da privatização do banco Crédit Mutual et Comercial de Paris, cuja proposta do ABN Amro não foi aceita.

\section{II.2.4.2 Casos de transações internacionais}

Conforme Dreifuss (2004), na década de 1990 as grandes empresas intensificaram suas estratégias e se concentraram na busca de uma atuação global, e de "uma nova divisão transnacional do trabalho, além de uma redistribuição da localização e administração da produção” (p. 89). As corporações, através do apoio de seus estados na conformação e amparo aos seus interesses, foram responsáveis, nas décadas de 70 e 80 , "pela multinacionalização das economias nacionais, constituindo o eixo diretor Norte-Norte e propiciando a abertura receptora no eixo Sul-Sul” (p. 90). Pode-se concluir, segundo o autor, que

Neste contexto, há alianças transnacionais que fazem parte de uma política de poder, já que os estados nacionais, por intermédio das corporações estratégicas, se situam em condições de assegurar uma presença ativa e determinante no processo e, por vezes, no controle socioeconômico e político de criação científica, conversão tecnológica, aplicação produtiva e comercialização. De fato, as corporações estratégicas preservam ainda uma 'base nacional' no que tange ao conhecimento. $O$ estado nacional continua como ator central, buscando responder a supostos interesses nacionais e à preservação da soberania, apesar das dificuldades para identificar uma territorialidade específica (legal, econômica ou tecnológica) devido às intensas formas de inter-relação e integração que ocorrem entre empresas, infra-estruturas e regras nas várias fases da concepção, produção, distribuição e consumo de bens e serviços (Dreifuss, 2004, p. 91-92). 
Para Batista Jr. (1997), as corporações transnacionais são, na realidade, em número muito reduzido. Ao contrário da ideologia da transnacionalidade dessas empresas "a grande maioria das empresas continua a ter um centro de gravidade nacional”. A Nestlé, por exemplo, detém $95 \%$ da produção no estrangeiro, enquanto o do controle do seu capital (aproximadamente 97\%) é suíço (p. 12). Sobre as transnacionais, ou multinacionais, afirma:

O comportamento das grandes empresas é caracterizado por uma certa ambivalência. Por outro lado, querem propagandear o seu caráter supostamente "transnacional", querem fazer crer que não têm identificação especial ou preferencial com o país onde se localiza a sua matriz. Por outro lado, nas horas decisivas, costumam pedir o apoio e a intervenção dos seus governos de origem na disputa por mercados e concorrência no mundo inteiro (Batista Jr., 1997, p. 12).

De acordo com Dreifuss, as corporações teriam induzido, ainda, a oligopolização e a oligopsonização transnacional na década, transformando o mundo "em um conjunto de teias ou tecidos (...) montados e estruturados em rede-de-corporações transetoriais e transnacionais". Desde então, o que se vê é o reforço "de tendências de integração tecnoprodutiva, concentração financeira, controle de estruturas e capacidades de pesquisa por parte dos grandes grupos existentes" (p. 105). Assim, as corporações procuram criar estruturas em rede, a partir de fusões e incorporações (p. 107) ${ }^{53}$. O conceito de rede foi mais difundido a partir da década de 1990, mas não será tratado no âmbito deste trabalho.

\footnotetext{
${ }^{53}$ Dreifuss (2004), ao tratar das rápidas transformações atuais, fala em "corporações estratégicas transnacionais" (CETs), capazes de orientar a produção "por matrizes científicas e por eixos tecnológicos", em cujo centro encontramos empresas de microeletrônica, informática, genética e telecomunicações, sendo que algumas, há 25 anos atrás nem mesmo existiam, e hoje encontram-se "no ranking mundial das maiores e melhores" (Dreifuss, 2004, p. 84).
} 
Tabela II.4:

Transações nos EUA e Europa - 1992/1994

\begin{tabular}{|c|c|c|c|}
\hline Empresa Compradora & Adquirida & Setor & Valor (US\$ bilhões) \\
\hline Roche Holding (Suíça) & Syntex (EUA) & Farmacêutico/Saúde & 5,3 \\
\hline Sandoz (Suíça) & Garber Products (EUA) & Farmacêutico/Saúde & 3,7 \\
\hline SmithKline Beecham (Reino & Diversified Pharmaceutical Services & Farmacêutico/Saúde & 2,3 \\
\hline Elf Sanofi (França) & Sterling Winthrop (unidade da & Farmacêutico/Saúde & 1,8 \\
\hline Health Care (EUA) & Health Trust (EUA) & Farmacêutico/Saúde & 3,0 \\
\hline Lloyd's Bank (R.U.) & Chaltenham \& Gloucester Building & Financeiro & 2,7 \\
\hline Commercial Union (R.U.) & Empresa de Seguros do Grupo & Financeiro & 2,2 \\
\hline Bank America (EUA) & Continental Bank (EUA) & Financeiro & 1,9 \\
\hline Burlington Nothem (EUA) & Santa Fé Pacific (EUA) & Transporte Ferroviário & 2,7 \\
\hline Union Pacific (EUA) & Chicago and North Western (EUA) & Transporte Ferroviário & 5,7 \\
\hline Illinois Central (EUA) & Kansas City Southern (EUA) & Transporte Ferroviário & 0,9 \\
\hline Norfol, Southern (EUA) & Concail & Transporte Ferroviário & 7,1 \\
\hline BMW (Alemanha) & Rover (R.U.) & Outros Setores & 2,3 \\
\hline Alied-Lyons (R.U.) & Pedro Domecq (Espanha) & Outros Setores & 1,2 \\
\hline BAT Industries (R.U.) & American Brands & Outros Setores & 1,0 \\
\hline British Petroleum (R.U.) & Petromed (Espanha) & Outros Setores & \\
\hline Johnson \& Johnson (EUA) & Neutrogena (EUA) & Outros Setores & 1,0 \\
\hline Reliance Eletric Co. & General Signal Corp. & Outros Setores & 10,0 \\
\hline Lockheed & Martin Marietta & Outros Setores & 10,0 \\
\hline Reed Elsvier (R.U.) & Mead Corporation (EUA) & Outros Setores & 1,5 \\
\hline Ártemis (França) & FMC (França) & Outros Setores & 0,4 \\
\hline Macy’s & Lojas Depto. Federal Store & Outros Setores & 4,1 \\
\hline
\end{tabular}

Fonte: Triches, 1996, p. 17.

Exemplos das diversas transações internacionais, realizadas nos setores que mais se destacaram nesses negócios, entre 1992 e 1994, além dos correspondentes valores, são encontrados na tabela II.4, sendo possível estabelecer uma comparação entre as suas cifras e os valores envolvidas nos negócios realizados posteriormente (representados na tabela II.5):

Triches (1996) referia-se às transações do início da década de 1990 como geradoras de maior concentração de mercados, pois as empresas estariam buscando as áreas em que deteriam maior capacitação tecnológica e domínio dos métodos de produção, como, entre outros casos, a venda da cadeia de hotéis Méridien pela Air France, a venda das participações no setor de eletroeletrônicos pelo Crédit Lyonnais, e a venda da divisão de satélites comerciais da British Aerospace para a Mutra Marconi Space. Teria ocorrido, ainda, uma adequação das empresas, através de fusões e aquisições, a um ambiente que se transformava 
rapidamente, causadas pelo aumento da retração dos mercados, reformas governamentais e mudanças tecnológicas nos setores de defesa, remédios, assistência e saúde, mídia e telecomunicações. O exemplo dos EUA é significativo: em 1994 foram contabilizados 2.997 negócios, que alcançaram cerca de US\$ 226,7 bilhões, uma das maiores cifras até então contabilizadas no país (p. 16). Já na Europa Oriental, no mesmo período, muitos negócios foram incentivados pelo processo de privatizações causado por transformações políticoeconômicas (p. 17).

À partir de 1995, ocorreram diversos casos entre grandes empresas, no setor de alimentos, como Nestlé (Suíça), Danone (França), Melitta (Alemanha), Parmalat (Itália), Bongrain (França), Milkaut (Argentina), Royal Numico (Holanda), representando o lado comprador. Na ponta dos vendedores, empresas que encontraram dificuldades, desistiram do negócio, não conseguiram enfrentar a concorrência ou não conseguiram alavancar financiamentos, tais como: Filtros de Papel Jovita, Tostines, São Luís, Campineira, Paulista, Fruti, Etti, Bethânia, Alimba, Café Três Corações, Mococa S.A., todas empresas brasileiras.

Por outro lado, também podem ser encontradas, na ponta vendedora, por exemplo, casos de empresas dos EUA compradas por empresas dos EUA (mas há também, casos como o da Mother's, norte-americana, vendida para a italiana Parmalat), além dos casos da Towerkop Dairy Ltd. (África do Sul), e da Ault Foods Ltd. (Canadá) também vendidas para a Parmalat.

A Parmalat, líder no segmento, foi apontada como um exemplo de eficiência e administração em meio a desastres que aniquilaram diversas empresas. Ela operou uma estratégia de aquisição repleta de êxitos (principalmente no Brasil), fortemente amparada em um agressivo marketing esportivo, mas terminou por envolver-se em operações contábeis fraudulentas, com mudanças no comando, até a intervenção judicial na Itália e no Brasil, em fevereiro de 2004 (Champi Jr e Barbosa, 2004).

A Nestlé é a maior empresa no setor de alimentos, com um faturamento da ordem de US\$ 61 bilhões (2001) e US\$ 65 bilhões (2002). A empresa, além de produzir e processar alimentos, atua através de subsidiárias que vendem bebidas, produtos lácteos e culinários, comidas congeladas, chocolates, produtos refrigerados, produtos para o desenvolvimento de alimentos, comidas para animais domésticos (Ralston Purina), produtos farmacêuticos e cosméticos. Em 1999 ela vendeu sua divisão de torrefação de café localizada nos EUA, para se concentrar na produção de café instantâneo, através das marcas Nescafé e Taster's Choice 
(Dreifuss, p. 139). A empresa, que já detinha 30\% do mercado de sorvete dos EUA, incorporou em 2002 a Dreyer's (proprietária ou licenciadora de marcas como Dreyer's, Edy's e Godiva) tornou-se a primeira empresa do setor naquele país. Ela também controla $50 \%$ da Haägen-Dazs, e adquiriu na Europa a Schoeller Suedzucher AG (2001). Tornou-se o maior fabricante mundial de chocolates, após adquirir as empresas: Perugina e Buittoni (Itália), Bouquet d'Or (França) e Rowntree (Inglaterra). A Nestlé lidera também no setor de água mineral, com 16\% do mercado em 2002, seguida pela Danone. Diversas marcas de propriedade da Nestlé pertenciam a empresas que atuavam nos mesmos setores de seus produtos, e foram mantidas após as aquisições (Dreifuss, p. 142-144).

As corporações estratégicas transnacionais, inter-relacionadas setorialmente em telecomunicações, informática e computação (Dreifuss, p. 107), muitas vezes associadas aos setores de mídia e de comunicações impulsionaram as fusões e alianças. Transações relevantes ocorreram em 1995 no setor de mídia: A Time Warner agregou a Turner Broadcasting System Inc, e tornou-se o maior conglomerado mundial de lazer e mídia. A Capital Cities/ABC e a Disney fundiram-se. A Silver King Communications Inc. e a Home Shopping Network também fundiram-se. A CBS comprou a Telenotícias, interessada no mercado latino-americano. Surgiu a PanAmSat Corporation, empresa resultante da compra da PanAmSat pela Hughes Eletronics, uma divisão da General Motors, por US\$ 3 bilhões, criando a maior empresa mundial de satélites54.

A WorldCom adquiriu a MFS Communications, em troca de ações que atingiu US\$ 14 bilhões, em seguida ao anúncio da aquisição, pela MFS, de outra empresa, a UUNET Techonologies (US\$ 2 bilhões). A empresa resultante surgiu com o objetivo de oferecer serviços de telefonia local, internacional e acesso à internet, agregando serviços de transmissão de voz, dados, imagens e acesso à internet através de fibra ótica55. Estava em preparação o caminho para a fusão de duas gigantes: MCI e WorldCom, até então o negócio mais caro da história, em uma proposta realizada pela WorldCom com ágio de $41 \%$ sobre o valor da empresa. A WorldCom comprou a Compuserve e logo em seguida revendeu uma

\footnotetext{
${ }^{54}$ Folha de S. Paulo, 22/09/1996, Caderno Dinheiro, p. 2.

${ }^{55}$ Folha de S. Paulo, 27/08/1996, Caderno Dinheiro, p. 7.
} 
parte dessa empresa para a America On Line; ao mesmo tempo, comprou a Brooks Fiber Properties, que vende serviços locais de telefonia, por US\$2,9 bilhões56.

Em 1985, nos EUA, fundada por Steve Case, surgiu a Quantum. Em 1991 passou a ser conhecida como America On Line, após fusão com a Netscape. Ela se tornou a maior provedora de serviços de internet, ao firmar acordo com a Microsoft para a distribuição de kits de acesso do Internet Explorer (da Microsoft) aos seus assinantes, enquanto a Microsoft incluía no Windows, além do seu próprio provedor de acesso (o MSN Messenger), uma configuração facilitadora de acesso para assinantes da AOL, graças ao qual tornou-se a maior provedora de acesso à internet (29 milhões de usuários em 2001). Além disso, ela fechou acordos com empresas como PCS Group (divisão de telefonia sem fio da Sprint Corp.), Nokia e Motorola, entre outras, para fornecer serviços de internet por equipamentos wireless57 (principalmente aparelhos celulares), mas também com a Research Motion Ltd. (Setor de Pagers interativos); Bellsouth Corp. (telefonia local) e Arch Communications Group Inc. (segunda maior empresa do mundo no setor de pagers). Adquiriu, em 1999, a When.com (calendários virtuais), e em 2000, firmou acordo com o Citigroup Inc. a fim de oferecer formas de pagamento e outros serviços bancários pela internet. A AOL adquiriu participações junto ao segundo maior provedor de acesso da Europa (AOL Europa), e na Austrália (AOL Austrália), além de comprar outras empresas: Sandpiper, Networks Inc., InfoSpace Inc., Inktomi Corp., Excite Inc. Chinadotcom Corp., eMusic.com Inc., Net2Phone Inc. (40\% do tráfego de Internet por telefone e de serviços de telefonia via internet, controlada pela IDT Corp., nos EUA), e Palm Computing Inc. (líder do mercado de palmtops) (Dreifuss, p. 484487).

A AOL também absorveu a Time-Warner, em um negócio considerado por Dreifuss (2004) como "a maior transação da história do capitalismo" (p. 490), e que teria alcançado US\$ 184 bilhões. De acordo com a tabela II.5, que apresenta dados publicados pela imprensa, a fusão AOL/Time-Warner teria sido realizada por US\$ 112 bilhões, atrás da MCI-Sprint e Vodafone/Manesmann. Independente dessa variável, a fusão AOL/Time-Warner forma a quarta maior corporação dos EUA, atrás apenas da Cisco, General Eletric e Microsoft,

\footnotetext{
${ }^{56}$ Folha de S. Paulo,02/10/1997, Caderno Dinheiro, p. 1; 17/10/1997, Caderno Dinheiro, p. 2; 12/11/1997, Caderno Dinheiro, p. 20.

${ }^{57}$ Refere-se aos diversos tipos de equipamentos de comunicação utilizados em redes virtuais, conforme http://www.trellis.com.br/.
} 
avaliada em US\$ 350 bilhões, ou seja, um verdadeiro mega-conglomerado de empresas e negócios (Dreifuss, p. 494).

Essa relação de negócios não esgota as transações realizadas, mas ilustra o dinamismo do setor de telecomunicações, para onde convergem empresas de comunicação, de telefonia e televisão, gravadoras e outras empresas, - neste setor foram realizados alguns dos maiores negócios mundiais na década de 1990. Denominado por Dreifuss (2004) como infoentretenimento (p. 490), pode ser exemplificado pelo conglomerado Time-Warner, que resultou da fusão em 1989, dos grupos Time (a revista Time surgiu em 1923 e a Life em 1936) e Warner Bros (o primeiro estúdio dos irmãos Warner é de 1922), e envolve empresas de TV a cabo (TNT, Cartoon Network, HBO, TBS, entre outros), constituiu alianças com Toshiba, Itochu e US West para operar sistemas de TV a cabo no Japão. Na indústria do cinema engloba: Warner Bros., Castle Rock Entertainment, New Line Cinema, Looney Tunes, Home Box Offic (HBO) e controla 19\% da CBS, adquirida em 1995 pela Westinghouse Electric Corporation. A rede CBS possuía estações de televisão, radiodifusão, mais de 200 emissoras de TV, 585 estações de rádio afiliadas, 50\% da distribuição de vídeo e DVDs, além do estúdio de produção Radford Studio Center Inc. e de participações acionárias, e foi comprada pela Viacom (US\$ 37,7 bilhões) em 1999 (p. 491-492).

Na tabela II.5, apresentada a seguir, percebe-se a presença dominante de transações nos setores de telecomunicações. Aparentemente, o maior volume de transações indica o dinamismo do setor e o acirramento da competição. A tabela II.5 também representa os casos de negócios ilustrativos de algumas megafusões, exemplos dos maiores negócios até então realizados, e que não casualmente ocorreram no setor de telecomunicações. Na tabela II.5 e II.6 os negócios encontram-se listados pelos maiores valores envolvidos, independentemente dos setores.

A fusão entre Vodafone (Reino Unido) e AirTouch, à época a maior companhia de telefonia móvel do mundo, possibilitou à Vodafone o acesso, além do mercado europeu, ao mercado asiático e posicionar-se nos EUA. O negócio, anunciado por US\$ 54 milhões, alcançou US\$ 60,3 milhões, e foi um dos dez maiores negócios da década (vide tabelas II.5 e II.6). 
Tabela II.5:

As maiores fusões e aquisições mundiais (em valores)

\begin{tabular}{|c|c|c|c|}
\hline & Empresas & Setor & (US\$ bilhões) \\
\hline $1^{\circ}$ & Vodafone Air Touch/Mannesmann & Telecomunicações & 186 \\
\hline $2^{\circ}$ & MCI/Sprint & Telecomunicações & 129 \\
\hline $3^{\circ}$ & AOL/Time Warner & Comunicações & 112 \\
\hline $4^{\circ}$ & Exxon Corp/Mobil Corp & Petrolífero & 82,8 \\
\hline $5^{\circ}$ & Citicorp/Travelers & Financeiro & 72,6 \\
\hline $6^{\circ}$ & Ameritech/SBC & Telecomunicações & 62,6 \\
\hline $7^{\circ}$ & BankAmerica/Nations B. & Financeiro & 61,6 \\
\hline $8^{\circ}$ & AT\&T/Media One & Telecomunicações & 60,5 \\
\hline $9^{\circ}$ & Vodafone/AirTouch & Telecomunicações & 60,3 \\
\hline $10^{\circ}$ & TotalFina/Elf-Aquitaine & Petrolífero & 54,2 \\
\hline $11^{\circ}$ & BP/Amoco & Petrolífero & 54,0 \\
\hline $12^{\circ}$ & AT\&T/Tele-Communic. & Telecomunicações & 53,6 \\
\hline $13^{\circ}$ & Bell Atlantic/GTE Corp. & Telecomunicações & 53,4 \\
\hline $14^{\mathrm{o}}$ & France Télécom/Orange plc & Telecomunicações & 46 \\
\hline $15^{\circ}$ & MCI/WorldCom & Telecomunicações & 43,4 \\
\hline $16^{\circ}$ & Daimler-Benz/Chrysler & Automobilístico & 40,5 \\
\hline $17^{\circ}$ & Monsanto/American Home* & Farmacêutico & 39,1 \\
\hline $18^{\circ}$ & Wells Fargo/Norwest & Financeiro & 34,4 \\
\hline $19^{\circ}$ & Bank Of Scotland/National Westminster & Financeiro & 34,1 \\
\hline $20^{\circ}$ & Bank Tokyo/Mitsubishi & Financeiro & 33,8 \\
\hline $21^{\circ}$ & US WEST/acionistas & Financeiro & 31,7 \\
\hline $22^{\circ}$ & NYNEX/Bell Atlantic & Telecomunicações & 30,8 \\
\hline $23^{\circ}$ & EDS/acionistas & Financeiro & 29,7 \\
\hline $24^{\circ}$ & First Chic/BankOne & Financeiro & 29,6 \\
\hline $25^{\circ}$ & RJR Nabisco/Kohlber & Consult. Financeira & 29,4 \\
\hline $26^{\circ}$ & Ciba-Geigy/Sandoz AG & Química & 28,0 \\
\hline $27^{\circ}$ & Assc. 1st Cap/acionistas & Financeiro & 26,6 \\
\hline $28^{\circ}$ & Lucent/acionistas & Telecomunicações & 24,1 \\
\hline $29^{\circ}$ & Taiyo Kobe/Mitsui Bank & Financeiro & 23,0 \\
\hline
\end{tabular}

A participação do setor financeiro nas transações também é bastante expressiva, sendo que a maior parte dos negócios ocorreu nos EUA, país onde, só no primeiro semestre de 1995, as fusões e aquisições movimentaram um total de US\$ 210 bilhões. Para exemplificar o aumento das transações, até o final daquele ano as cifras alcançaram valores próximos a US\$ 800 bilhões (Lodi, 1999, p. 13). 
Tabela II.6:

Maiores transações mundiais de fusões e aquisições em 1999 (bilhões)

\begin{tabular}{llc}
\hline \multicolumn{1}{c}{ Comprador } & \multicolumn{1}{c}{ Adquirido } \\
\hline Vodafone Group plc (R.U.) & Airtouch Communications Inc. (EUA) & 60,3 \\
Zeneca Group plc (R.U.) & Astra AB (Suécia) & 37,7 \\
BP Amoco & Arco Atlantic Richfield Co. (EUA) & 34,0 \\
Hoechst AG (Alemanha) & Rhône Poulenc S.A. (França) & 22,0 \\
Repsol S.A. (Espanha) & YPF (Argentina) & 15,4 \\
Deutsche Telecom (Alemanha) & One 2 One (R.U.) & 13,6 \\
Total S.A. (França) & Petrofina (Bélgica) & 11,2 \\
Wall Mart Stores (EUA) & Asda Group plc (R.U.) & 10,6 \\
Aegon NV & TransAmerica Corp & 9,7 \\
BAT Industries plc (R.U.) & Rothmans International Holdings BV & 8,5 \\
\hline
\end{tabular}

Fonte: KPMG Corporate Finance, 1999 (Gazeta Mercantil Latino Americana, 22 a 28/11/99)

Os grandes negócios ocorridos no período 1998-2000, inigualáveis em termos dos valores alcançados, totalizaram uma quantia superior à soma dos negócios realizados nos 30 anos anteriores nos EUA. Entretanto, alguns desses negócios partiram de uma análise equivocada da realidade e das suas conseqüências imediatas. $\mathrm{O}$ caso da fusão AOL/Time Warner: um dos maiores negócios de todos os tempos, é apontado como exemplo de prejuízo contábil: em abril de 2002 a empresa assumiu um prejuízo de US\$ 54 milhões. Antes dela, algumas das maiores empresas dos EUA também apresentaram prejuízos e, inclusive, faliram, como a Enron $^{58}$, WorldCom, Tyco, Arthur Andersen, entre outras de menor porte ${ }^{59}$.

\section{II.2.5 Investimentos estrangeiros diretos (IEDs) na América Latina}

De acordo com a Cepal (1998), os EUA aplicaram 30,2 bilhões de dólares em IEDs em 1990, na América Latina, valor quase triplicado em 1997, quando atingiu 83,8 bilhões de

\footnotetext{
58 "A maior falência da história, a da gigante de energia Enron Co., em dezembro passado, foi apenas o ponto de partida de uma sucessão de escândalos, envolvendo fraudes contábeis, executivos reverenciados no mundo corporativo e até mesmo o presidente da República. A Enron era um dos ícones da nova economia. De pequena empresa voltada à exploração de gás natural passou a ser a sétima colocada entre as maiores corporações americanas, com um total de três mil subsidiárias, 20 mil empregados e volume de negócios de US\$ 100 bilhões em 2000. No entanto, boa parte desta pujança era ficção contábil. Para esconder as falcatruas responsáveis por inflar os resultados, a companhia contou com o apoio da auditoria Arthur Andersen, que até queimou documentos comprometedores quando o escândalo veio à tona". Eliana Raffaelli, "O Risco está mesmo no Brasil?", http://www.ufrgs.br/

${ }^{59}$ Rodney de Castro Peixoto, http://www.issabrasil.org/, pesquisado em 10/09/2004.
} 
dólares. Destes, ao Brasil foram destinados 47,6\%, em 1990, e 42,6\% em 1997, concentrados sobretudo no setor de manufaturados.

Tabela II.7:

ACERVO DE IEDS DOS EUA NA AMÉRICA LATINA, POR SETORES - 1990-1997

(em milhões de dólares).

\begin{tabular}{|c|c|c|c|c|c|c|c|c|c|c|}
\hline Setores & \multicolumn{2}{|c|}{ Argentina } & \multicolumn{2}{|c|}{ Brasil } & \multicolumn{2}{|c|}{ Chile } & \multicolumn{2}{|c|}{ México } & \multicolumn{2}{|c|}{ Venezuela } \\
\hline Ano & 1990 & 1997 & 1990 & 1997 & 1990 & 1997 & 1990 & 1997 & 1990 & 1997 \\
\hline Total & 2.531 & 9.766 & 14.384 & 35.727 & 1.896 & 7.767 & 10.313 & 25.395 & 1.087 & 5.176 \\
\hline Petróleo & 471 & 1.427 & 507 & 1.769 & $\mathrm{a}$ & $\mathrm{a}$ & $\mathrm{a}$ & 109 & 113 & 1.232 \\
\hline Manufaturas & 1.366 & 4.017 & 11.494 & 22.584 & 226 & 743 & 7.784 & 15.119 & 674 & 1.833 \\
\hline Alimentos & 334 & 1.014 & 1.030 & 3.412 & 19 & 141 & 1.119 & 5.025 & 68 & 375 \\
\hline Prod. Químicos & 367 & 1.563 & 1.766 & 4.867 & 132 & 385 & 1.703 & 3.157 & 223 & 258 \\
\hline Equipamentos e Maquinaria & $\mathrm{a}$ & 24 & 2.243 & 1.340 & 1 & 2 & 532 & $\mathrm{a}$ & $\mathrm{a}$ & 36 \\
\hline Equipamentos Elétricos & 27 & $\mathrm{a}$ & 731 & 1.936 & $\mathrm{a}$ & $\mathrm{a}$ & 676 & 803 & 42 & 89 \\
\hline Material de Transporte & 49 & 345 & 1.669 & 3.603 & $\mathrm{a}$ & $\mathrm{a}$ & 1762 & 1.920 & 89 & 474 \\
\hline Comercio & 150 & 506 & 157 & 656 & 163 & 437 & 551 & 862 & 179 & 294 \\
\hline Bancos & 337 & 1.181 & 513 & 1.489 & 360 & 639 & $\mathrm{a}$ & 510 & $\mathrm{a}$ & $\mathrm{a}$ \\
\hline Outros Serviços Financeiros & 168 & 1.337 & 1.433 & 4.711 & 873 & 2.480 & 619 & 4.079 & $\mathrm{a}$ & 59 \\
\hline Outros Serviços & 43 & 711 & 118 & 1.602 & $\mathrm{a}$ & 218 & 291 & 924 & 23 & 87 \\
\hline Outros Setores b & 26 & 588 & 163 & 2.915 & 125 & $\mathrm{a}$ & 963 & 3.792 & 13 & $\mathrm{a}$ \\
\hline
\end{tabular}

Fonte: Cepal, Informe 1998.

a) informação não fornecida pelo BEA;

b) incluem agricultura, silvicultura e pesca, mineração, construção, transporte, comunicações, eletricidade, gás e serviços sanitários.

O México, segundo país de destino dos IEDs norte-americanos, recebeu no mesmo período $34,2 \%$ e $30,3 \%$, concentrados também no setor de manufaturados. Os demais países, Argentina, Chile e Venezuela somam 18,2\%, em 1990, e 27,1\%, em 1997 (ver tabela II.7). 


\section{II.2.6 Internacionalização de empresas da América Latina}

Além dos investimentos estrangeiros realizados na região, ao final da década iniciouse o processo de internacionalização de diversas empresas de países latino-americanos. No gráfico II.1 representa-se a quantidade de empresas por países, cujos dados encontram-se no Anexo 1.

Gráfico II.1

\section{Empresas mais competitivas por país}

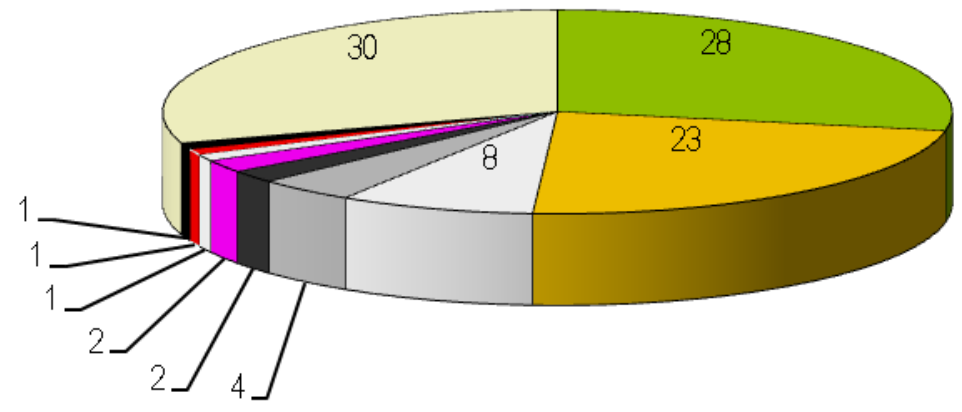

\begin{tabular}{|lllll|}
\hline पBrasil & $\square$ Chile & 口Argentina & 口Colômbia & 口Peru \\
$\square$ CostaRica & $\square$ Nicarágua & -Panamá & $\square$ El Salvador & 口México \\
\hline
\end{tabular}

Fonte: América Economia, 28/03 a 10/04/2003.

No Mapa II.1, são apresentadas as 100 empresas mais competitivas da América Latina, e sua participação por país.

A internacionalização das empresas brasileiras foi de $1 \%$ em 1999, de 3,4\% em 2000, de $4 \%$ em 2001 e de 5,8\% em 2002, quando algumas empresas realizaram transações no exterior, como a Petrobrás, que adquiriu a Perez Companc, a Embraer, que estabeleceu joint venture com uma empresa chinesa, e a Gerdau, que adquiriu ativos nos EUA, entre outras60.

$\overline{{ }^{60} \text { O Estado de S. Paulo, 19/12/2002. }}$ 


\section{Mapa II.1:}

\section{América Latina - Distribuição das 100 empresas mais competitivas:}

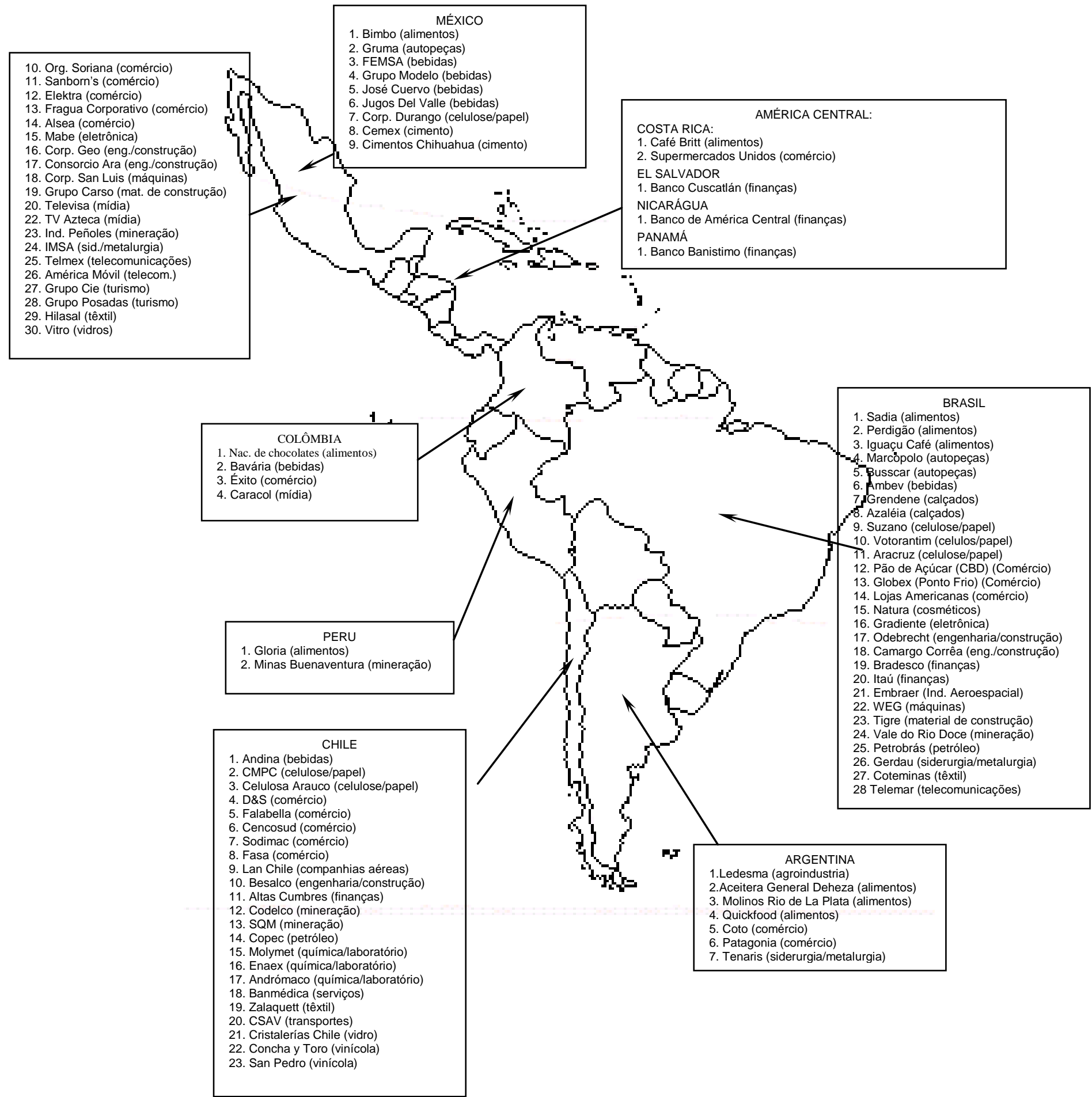

Fonte: América Economia, n 250, março/abril de 2003. 


\section{II.3. Conclusões}

Optou-se de forma resumida, pela comparação entre os países relacionados, ainda que portadores de realidades econômicas díspares e sob diferentes enfoques, com o intuito de analisar o processo que culminou em liberalização e reformas econômicas, inclusive através da privatização de empresas estatais.

No caso da Grã-Bretanha, o aparente sucesso do processo desenvolvido neste país serviu de exemplo para outras economias. Com base nesse modelo, países com economias muito diferentes buscaram a solução de seus problemas e a adequação de suas economias às diretrizes estabelecidas no centro do sistema ${ }^{61}$. As soluções econômicas apontavam para a subordinação dos países ao imperativo da globalização ${ }^{62}$, contudo os governos neoliberais aceitaram a injunção de que não haveria solução fora das regras do mercado. Diante de uma situação de crise profunda, como aquela que historicamente incide sobre América Latina e submete os seus países a situações de atraso e dependência econômica, a alternativa encontrada pelos diversos governos latino-americanos foi a de se adequar as orientações dos organismos financeiros internacionais e adaptar as economias de seus países às imposições do mercado. A tendência, grosso modo, era a de diminuir o papel do Estado-empresário e enfraquecer seu papel nas decisões de planejamento e orientação econômica de suas respectivas economias ${ }^{63}$.

Do que foi exposto, se as privatizações contribuíram para o aumento de aquisições e fusões, deve-se ressaltar que este não foi um processo isolado, pois houve um incremento na

\footnotetext{
61 “A discussão em torno dos gastos públicos e do 'tamanho' do Estado congruente com as atuais condições da América Latina tomou uma importância e uma urgência excepcionais. As razões são várias: por um lado, a gravidade da crise capitalista que, iniciada no começo dos anos 70, não mostra ainda sinais de genuína resolução. Isto estimulou uma verdadeira enxurrada de críticas contra o que agora se considera um excessivo intervencionismo estatal, a maioria das quais foram articuladas recorrendo aos postulados clássicos da teoria liberal. Dado que a crise golpeou muito duramente os países da região, não é de estranhar que o discurso antiestatista dos centros tenha ganhado rápida difusão na América Latina” (Borón, 1994, p. 185).

62 "Em novembro de 1989, reuniram-se na capital dos Estados Unidos funcionários do governo norte-americano e dos organismos financeiros internacionais ali sediados - FMI, Banco Mundial e BID - especializados em assuntos latino-americanos. (...) Ratificou-se, portanto, a proposta neoliberal que o governo norte-americano vinha insistentemente recomendando, por meio das referidas entidades, como condição para conceder cooperação financeira externa, bilateral ou multilateral." (Batista, 1999, p. 11)

63 "O Estado, que desde os anos 30, havia sido um meio idôneo para encarar a crise, foi ideologicamente convertido no 'bode expiatório' e concebido como o fator que a origina. Antes, nos amargos anos 30, ele havia sido parte da solução: agora passou a ser - nas versões mais ululantes do neoliberalismo - a totalidade do problema" (Borón, 1994, p. 187).
} 
quantidade de fusões e aquisições entre empresas em praticamente todos os setores, em um processo liderado pelo capital financeiro. Além disso, os negócios entre bancos preponderaram, em uma série de compras e fusões, em associações que redundaram em gigantes do setor (processo relatado no capítulo IV). As transações obedeceram, em grande parte, às opções de natureza estratégica das empresas, em busca de aumento da lucratividade. As fusões e aquisições seriam mais interessantes do que a realização de altos investimentos na construção de novas plantas ou novos empreendimentos (denominados green-fields). Houve, ainda, um aumento das transações transfronteiriças, através das quais as grandes empresas de capital estrangeiro puderam realizar a sua expansão. As economias mais desenvolvidas lideraram o processo, tendo à frente a maior delas, os EUA.

No caso da América Latina, é bastante significativa a participação nas transações das empresas dos EUA. Nesta região do planeta, endividada e sob a iminência das diversas crises, os Estados nacionais foram constrangidos a abdicar de maiores participações na promoção do desenvolvimento econômico, liberando os seus respectivos mercados à atuação das empresas. Como reflexo dessa nova realidade, a América Latina comparece com 100 empresas competitivas (vide Mapa II.1), majoritariamente associadas aos setores primários da economia, comércio e serviços. Ademais, a maior parte dessas empresas concentra-se em apenas três países: México, Brasil e Chile (gráfico II.1). É sintoma característico da região que a maior parte das suas maiores empresas estejam relacionadas (em termos de vendas) aos setores de alimentos ${ }^{64}$ (Bimbo e Gruma/México); bebidas (Ambev/Brasil; Femsa e Grupo Modelo/México), bancos (Itaú e Bradesco/Brasil); hidrocarbonetos (Petrobrás/Brasil e Copec/Chile), etc.. Independente da variável "valores de vendas"65, a participação da Telmex (México), no setor de telecomunicações, da Petrobrás (estatal), da Embraer (setor aeroespacial), da Odebrecht (Engenharia e Construção), da WEG (máquinas), da Cemex (cimento) ou do Grupo Industrial Saltillo (autopeças), estes exemplos parecem exceções. E afinal, a maior parcela de grandes empresas da América Latina, estatais ou privadas, de capital nacional, passaram para o controle do capital estrangeiro. De acordo com Dreyfuss "Os processos de concentração e reconcentração foram intensos em toda parte" (p. 147),

\footnotetext{
64 "Há poucas corporações, gigantescas, controlando a alimentação mundial. Muitas das antigas empresas desapareceram, em alguns casos virando marcas. Algumas continuam funcionando como parte de outras corporações, uma vez que houve centenas de aquisições nas indústrias de alimentos, de higiene e de artigos para limpeza." (Dreyfuss, 2004, p. 138)

${ }^{65}$ Refere-se ao Anexo I.
} 
entretanto, no caso específico do continente latino americano, as consequiências de tais processos não se referem apenas a sua intensidade, pois ao causarem o aumento da desnacionalização das economias de seus países, também causaram uma inserção subordinada e dependente de seus países na chamada economia "globalizada".

Frente ao exposto, conclui-se que o "modelo" implementado na Grã-Bretanha, apontado como exemplo a ser seguido para os países latino-americanos, ampliou as contradições sociais nos países da região, prejudicou as suas instituições e economias e parece retardar, ainda mais, a construção de países - e economias, portanto -, desenvolvidos, autônomos e independentes. 


\section{CAPÍTULO III - O MOVIMENTO DE FUSÕES E AQUISIÇÕES DE EMPRESAS E O PROCESSO DE PRIVATIZAÇÕES NO BRASIL}

\section{III.1. Breve histórico de fusões e aquisições anteriores à década de 1990 III.1.1. Introdução}

As transações relacionadas a fusões e aquisições ocorridas anteriormente no Brasil, cuja história é marcada pela presença do capital internacional é abordada nessa parte do capítulo. A segunda parte aborda o movimento e as transações da década de 1990.

Dos primeiros negócios realizados entre empresas no país, desde o Império ${ }^{66}$, até o episódio histórico envolvendo a fábrica de linhas do Coronel Delmiro Gouveia ${ }^{67}$, há alguns exemplos das dificuldades empresariais e das questões relativas a concorrência e da desnacionalização no país. Enquanto a primeira lei antitruste (Sherman Act), surge nos EUA em 1890, no Brasil a primeira legislação antitruste aparece ao final do Estado Novo, em 1945, com o Decreto-Lei no. 7.666, denominado Lei Malaia, de autoria do então Ministro do Trabalho, Agamennon Magalhães (Bandeira, 1975, p. 3 e Oliveira, 2001, p. 2).

Oliveira (2001) demonstra que o período compreendido entre 1937-1988 foi um período de defesa da economia popular, enquanto o período compreendido entre 1989-1994 seria um período de transição, e a partir de 1994 seria inaugurado no Brasil o período de defesa da concorrência (p. 2). Ao especificar, entretanto, esses dois aspectos da defesa da concorrência no país, Oliveira mostra que houve preocupações com a defesa da concorrência em legislações anteriores a 1994, como na própria Lei Malaia, cuja aplicação coube ao CADE (p. 4). Conforme Bandeira (1975) essa Lei foi considerada pelo Departamento de Estado norte americano como um ato de nacionalismo econômico, e no âmbito da oposição a Getúlio

\footnotetext{
${ }^{66}$ Talvez o primeiro caso de fusão ocorrido no Brasil tenha sido o do Banco do Brasil: "Fundado em outubro de 1808, por D. João VI, o Banco do Brasil foi fechado em 1829. Foi reaberto em 1851, por iniciativa do Barão de Mauá, fundindo-se posteriormente com o Banco Comercial (1853) e com o Banco da República do Brasil (1905)." (Sandroni, 2002, p. 44). A respeito dos negócios do Barão de Mauá, e aquisições como a do "Estabelecimento de Fundição e Estaleiros de Ponta de Areia", realizado em agosto de 1846, consultar Caldeira (2002), especialmente os capítulos 15 e 18.

${ }^{67}$ É conhecida a história desse industrial, assassinado em 1917, que "erigiu, na região do Rio São Francisco, uma fábrica de linhas para coser, competindo com a Machine Cotton, poderoso grupo inglês que dominava o mercado do produto, por meio de uma subsidiária, a Cia. Brasileira de Linhas para Coser, sediada em São Paulo. Resistiu a todas as pressões para cessar as suas atividades ou vender a fábrica, até que morreu, misteriosamente, assassinado. Ele sabia que estava ameaçado de morte pela Machine Cotton e a opinião pública nunca duvidou de que foram os dirigentes do grupo os empreiteiros do crime.” (Bandeira, 1975, p. 5).
} 
Vargas ela foi considerada um instrumento nazi-fascista. Deposto cinco meses após a assinatura da Lei, o ato de Vargas foi desfeito em seguida por José Linhares, presidente provisório (p. 3).

O ex-ministro do trabalho de Vargas apresentou projeto de lei em 1948, para possibilitar ao Estado brasileiro a repressão, na forma da lei, dos abusos do poder econômico. A preocupação, então, era com a exploração econômica exercida pelo capital internacional, a concentração e o controle exercido pelos grupos financeiros sobre os mercados (os dados apontavam para uma concentração dos capitais estrangeiros, conforme a tabela III.1). A iniciativa do deputado não prosperou, pois deixou a Câmara dos Deputados para assumir, em 1950, o cargo de governador de Pernambuco (Bandeira, 1975, p. 4).

Tabela III.1:

Indicadores de concentração nacional: 1940-1947

\begin{tabular}{|l|l|}
\hline \multicolumn{1}{|c|}{ Setor } & \multicolumn{1}{c|}{ Participação } \\
\hline Indústria têxtil & 10 empresas (entre 420) respondiam por 50\% da produção \\
\hline Produção de linho & 1 empresa (entre 30) controlava 56\% da produção \\
\hline Frigoríficos & 4 (entre 13) dominavam 33\% do mercado de compra de carne e 80\% da venda \\
\hline Cimento & 3 firmas (entre 10) manipulavam 73,7\% das vendas de cimento nacional \\
\hline Trigo & 5 firmas (entre 44) dominavam 56\% das importações \\
\hline Trigo & 8 moinhos (entre 99) detinham 73\% da produção e da venda no mercado brasileiro \\
\hline Siderúrgico & 4 empresas (entre 39) dominavam o mercado \\
\hline Siderúrgico & 1 empresa (entre 12) dominava cerca de 50\% da produção de ferro laminado \\
\hline Siderúrgico & 1 empresa (entre 17) dominava o equivalente a 45\% das vendas de ferro gusa \\
\hline Comércio & Os oligopólios regiam os mercados de venda de arroz, feijão, açúcar, sal, mate e leite \\
\hline
\end{tabular}

Fonte: Magalhães, A. apud Bandeira, 1975, p. 9.

Além do episódio envolvendo a Machine Cotton e a Cia. Agro-Fabril Mercantil, de Delmiro Gouveia, os casos da implantação da siderurgia, bastante dificultada pelo cartel internacional, a extração e refino do petróleo, sabotado principalmente pela Standard Oil (Bandeira, 1975, p. 8), e que redundaram na campanha $O$ petróleo é nosso, o caso da fábrica de álcalis, em desvantagem na concorrência com Du Pont e ICI, são exemplos das dificuldades enfrentadas pela indústria brasileira ${ }^{68}$.

\footnotetext{
${ }^{68}$ Para Bandeira (1975) a história econômica do Brasil foi acompanhada pelo domínio estrangeiro: "Talvez não se pudesse falar de desnacionalização numa economia que sempre esteve, estruturalmente, sob o domínio do capital financeiro internacional. A transferência de empresas nacionais para o controle estrangeiro, mediante
} 


\section{III.1.2. Alguns setores com participação estrangeira}

No Brasil os primeiros frigoríficos surgiram como produto do crescimento urbano do Rio de Janeiro e São Paulo, a partir da I Guerra Mundial, quando o interesse estrangeiro intensificou-se com o aumento das importações européias e o estímulo do governo brasileiro em ampliar as exportações, compensando a retração do comércio de café (Mamigonian, 1976). Para Bandeira (1975) a atuação desses frigoríficos era cartelizada, com o controle do preço da carne e de sua aquisição a preços baixos. Além desses expedientes, os frigoríficos adquiriam vastas extensões de terra, com o intuito de garantir o controle de preços e a produção de matérias primas, em uma prática comum também a "outras corporações estrangeiras, como Sanbra, Nestlé, Kibon, Citrobrasil, Refinações de Milho Brasil e Anderson Clayton" (idem, p. 69). Como exemplo, ressalte-se:

Um dos maiores frigoríficos estrangeiros, o Anglo, tinha aproximadamente 30 propriedades rurais no Brasil, sendo 15 delas no Estado de São Paulo. Esses imóveis foram registrados em nome da The Lancashire General Investiment Co. Ltd., companhia integrante do mesmo grupo inglês que dominava os Frigoríficos Anglo, no Brasil, Argentina e Uruguai. Só em Valparaíso, noroeste do Estado de São Paulo, ela possuía $1 / 3$ das terras do município, mantendo, além de 30.000 cabeças de gado, culturas de café e algodão (Bandeira, 1975, p. 69).

As fazendas do Anglo totalizavam cerca de 998.000 ha até 1967. Os frigoríficos Swift e Armour, adquiridos em sociedade com a Deltec International Ltd. (Rockfeller) pelo Grupo Brascan (Light \& Power) e Grupo Antunes (Hanna) - fundidos em uma só empresa - também eram proprietários de imensas áreas.

Conforme Bandeira (1975), a prática dos frigoríficos era a de não registrar as propriedades como suas, o que prejudicava o levantamento completo das áreas, e mantinham as suas denominações tradicionais, passando a impressão de que ainda seriam de propriedade de nacionais. Muitas propriedades se localizavam em áreas de fronteira com o Uruguai, o que possibilitava expedientes de evasão de divisas e sonegação de impostos, pelo "deslocamento

compra ou associação, acompanhou o desenvolvimento industrial do País, como consequiência do próprio movimento de acumulação, que tende a concentrar e a centralizar o capital em mãos dos grupos mais poderosos" (Bandeira, 1975, p. 12). 
clandestino do gado de um país para o outro, e as negociatas acobertadas pelas importações de carne", então isentas de impostos (Bandeira, p. 69-70).

Mamigonian (1976) explica as causas da crise dos frigoríficos estrangeiros no país, e enfatiza a aceleração da desnacionalização do setor de carnes, após 1955. Em 1941 os pecuaristas brasileiros conseguiram junto ao governo restringir o tamanho do rebanho dos frigoríficos estrangeiros. Dez anos depois, o governo Vargas criou linhas de crédito e isenções de taxas para estimular a criação de frigoríficos no interior do Brasil-Central. No período 1955-60 os frigoríficos estrangeiros perderam vantagens para ex-açougueiros e invernistas distantes dos grandes centros, ao mesmo tempo em que, ao monopolizarem o mercado, não se modernizaram, aumentaram as remessas de lucro e ampliaram o capital de giro. Exceção feita ao Anglo, todos os grandes frigoríficos estrangeiros foram vendidos, Swift, Armour e Wilson (p. 12-14). O controle do Frigorífico Anglo passou para a Refinação de Milho Brasil em 1994 (Triches, 1996, p. 25).

Conforme Bandeira (1975), no setor leiteiro, com a Nestlé à frente das empresas estrangeiras, o objetivo era aumentar a importação principalmente do produto industrializado (em pó); com queda na produção interna do leite, pois o governo incentivou a criação do gado de corte em detrimento do gado leiteiro (alegava-se que seria mais barato importar o leite, e sobravam incentivos ao gado de corte). Ao mesmo tempo, diminuiu o consumo de manteiga, substituída pelas margarinas Claybon (Anderson Clayton), Delícia e Flor (Sanbra) e Doriana (Gessy-Lever). Houve a suspeita da formação de cartel entre essas empresas, pois enquanto o consumidor foi demovido de utilizar o produto "manteiga", a sua matéria prima foi desviada para a fabricação de leite em pó. Aos poucos a produção e o consumo de margarina superou o de manteiga ${ }^{69}$. As empresas internacionais manipulavam os preços e as exportações, já em 1973, não só de carne ou leite, mas também de café, algodão, soja, etc.. No caso da cultura do trigo, os moinhos - estrangeiros, em sua maioria - dificultavam a produção interna, mas exerciam o controle e o domínio da importação. Nesse segmento do setor de alimentos, destacava-se o grupo Bunge y Born, que dominava o mercado ${ }^{70}$. No caso do trigo, conforme

\footnotetext{
69 "De uma única marca de margarina que havia em 1950 (Saúde) passou-se para 13 em 1973. Fábricas como Anderson Clayton, Sanbra, Matarazzo e Gessy-Lever deslocam cada vez mais a manteiga do mercado, cujos produtores, brasileiros, não contam com recursos para fazer publicidade" (Pereira, Osny D., apud Bandeira, 1975, p. 72-73).

70 "Desejo referir-me a outro truste que afeta o consumidor brasileiro, não só o nordestino - é o truste do trigo. Quando Ministro do Trabalho, lutei contra ele porque se instalara da maneira mais inteligente com concessões de moinhos no litoral do Brasil: Recife, Rio de Janeiro, Santos e Porto Alegre, sempre com nomes diferentes,
} 
Bandeira, entretanto, o que mais prejudicou a produção brasileira foram os acordos realizados pelos governos anteriores, e que estipulavam importações crescentes do produto, em detrimento da produção interna, o que se explica pela queda dos preços internacionais do produto, mais vantajosos em relação ao preço interno. Também o cacau era outro produto cujo monopólio de comercialização e industrialização era exercido pela Gill \& Duffus (com o controle de mais de $80 \%$ da safra).

O setor de avicultura era controlado pelas companhias norte-americanas, cuja entrada no mercado foi possível por associações com granjas locais. Foram introduzidas no país linhagens de aves para aumentar a produção de ovos e carnes, entravando e acabando com as iniciativas internas de desenvolvimento de tecnologia nacional. Associado a esse fato, foi fechado o Centro de Experimentação da Secretaria de Agricultura do Estado, por ordem do então governador Carlos Lacerda, em um ato que interessava às companhias norte-americanas e seus representantes no país, e cujo efeito foi a extinção deliberada do plantel formado ao longo de 12 anos de seleção por diversas raças das aves (Bandeira, 1975, p. 78). Com o fim do trabalho de pesquisa da Seção Experimental de Avicultura e Cunicultura (criação de coelhos), órgão subordinado ao Ministério da Agricultura e o encerramento das atividades de outras granjas (Rio Claro e Guanabara, no Rio de Janeiro), a produção de matrizes passou a ser controlada por granjas estrangeiras (Hy-Line, Kimber, Welph Line, Cobb, Shaver, H. \& N. e Arbor Acres). A Cargill Inc., dos EUA, passou a controlar a Shaver Poultry Breeding Farm, do Canadá, enquanto a Arbor Acres pertencia à International Basic Economy Co. (Grupo Rockfeller) (idem, p. 79-80). A conseqüência imediata foi a intensificação da dependência do país na importação de espécies (de cerca de US\$ 1,3 milhão em 1973). O setor de rações também caiu no domínio de empresas norte-americanas, com a entrada no mercado da Purina, Cargill, Central Soya e Anderson Clayton, em detrimento do setor nacional de produção.

Os casos aqui narrados não constituem exceções, mas representam a regra de todo o processo. Diversos casos poderiam servir de exemplo a situações semelhantes, mas é certo que havia uma preocupação sobre o assunto entre empresários e no próprio regime. A questão das fusões e incorporações estava no centro de muitas inquietações. Um exemplo foi o

empresas diversas, portanto autônomas. (...) Do estudo da organização dessas sociedades, de todos os moinhos, cheguei à conclusão de que todos pertenciam a Bunge y Born, com sede na Argentina. Eram eles que tinham a maioria das ações de todos os moinhos" (Magalhães, A., apud Bandeira, p. 8). 
simpósio realizado em 1971 sobre fusões e incorporações, em São Paulo, patrocinado pela Federação Brasileira das Associações de Bancos e o Instituto de Organização Racional do Trabalho, cuja preocupação era a de pensar a criação, no país, de empresas de grande porte, aptas a concorrer com empresas estrangeiras ${ }^{71}$.

Tabela III.2

Casos de aquisições no setor automobilístico - década de 1960

\begin{tabular}{|c|c|}
\hline Firmas & Grupos que assumiram o controle \\
\hline Metalúrgica Forshed (Forjaria S. Bernardo S.A.) & Volkswagen \\
\hline Varan Motor S.A. & Simca-Chrysler \\
\hline Willys Overland (53\% nacional) & Ford \\
\hline Bongotti S.A. & Willys-Ford \\
\hline Máquinas S. Francisco S.A. & Willys-Ford \\
\hline Albarus S.A. & Spicer \\
\hline Wquiel - Cia. Nacional de Equipamentos Elétricos & Bosch \\
\hline Wapsa & Grupo Suíço \\
\hline Terral S.A. & Massey Fergusson \\
\hline Minuano S.A. (Rio Grande do Sul) & Massey Fergusson \\
\hline Saturnia S.A. & Ray-O-Vac \\
\hline Mazzan S.A. & Eutectic \\
\hline D.L.R. Plásticos do Brasil & Heluma \\
\hline Fábrica Nacional de Motores & Alfa-Romeo \\
\hline
\end{tabular}

Fonte: Bandeira, 1975, p. 99.

\footnotetext{
${ }^{71}$ PÉCORA, José Flávio e outros. Simpósio sobre fusões e incorporações. São Paulo: Mestre Jou, 1972
} 
Tabela III.3:

Outras firmas adquiridas na década de 1960

\begin{tabular}{|c|c|c|}
\hline FIRMAS ADQUIRIDAS & FIRMAS COMPRADORAS & SETOR \\
\hline Tamura S.A. & Sony & Eletro-eletrônico \\
\hline Irmãos Negrini (IRNE) & Toshiba Tokyo Shibaura & Eletro-eletrônico \\
\hline Lins Material do Brasil & Hitachi & Eletro-eletrônico \\
\hline Adesite & Union Carbide & Plásticos \\
\hline Vulcan S.A. & Union Carbide & Plásticos \\
\hline Plastar S.A. & Grace & Plásticos \\
\hline Plavinil & grupo americano & Plásticos \\
\hline Cia. Brasileira de Caldeiras & grupo japonês & Mecânica e metalurgia \\
\hline Mapri - Indústria de Parafusos S.A. & grupo americano & Mecânica e metalurgia \\
\hline Nova Fundição de Máquinas Piratininga S.A. & Willys-Ford & Mecânica e metalurgia \\
\hline Metalúrgica Canco & American Can & Mecânica e metalurgia \\
\hline Metalúrgica Jundiaí (Sifco do Brasil) & American Machine \& Foundry & Mecânica e metalurgia \\
\hline Tintas Ipiranga & Esso Brasileira de Petróleo & Tintas \\
\hline Fios e Cabos Plásticos do Brasil & Anaconda & Metais não ferrosos \\
\hline S.A. Marvin & Anaconda & Metais não ferrosos \\
\hline Cia. de Cigarros Flórida & Ligget \& Myers (L\&M) & Cigarros \\
\hline Leite Pulvolac & Nestlé & Alimentação \\
\hline Chocolate Gardano & Nestlé & Alimentação \\
\hline $\begin{array}{l}\text { Moinhos de trigo (localizados nos } \\
\text { estados do CE, RN e PE) }\end{array}$ & Bunge y Born (Moinho Santista) & Alimentação \\
\hline $\begin{array}{l}\text { Fábrica de Peixe (Ind. de Alimentos } \\
\text { Carlos de Brito) }\end{array}$ & Grupo Light & Alimentação \\
\hline Cia. Cervejaria Caracu & Skol & Alimentação \\
\hline Grapete & Anderson Clayton & Alimentação \\
\hline Cotonifício Gávea S.A. & American Merchants (Sudantex) & Têxtil \\
\hline Empresa Industrial Garcia (SC) & Grupo Light & Têxtil \\
\hline Ind. Têxtil Fiação Maluf & Suzuki & Têxtil \\
\hline Cerâmica Colônia de Jundiaí & Ideal Standard & Material de construção \\
\hline Cia. de Cimento Barros & grupo suíço & Material de construção \\
\hline Schering (São Paulo) & Schering (EUA) & Farmacêutico \\
\hline Laboratório Fontoura & Wyeth & Farmacêutico \\
\hline Laborterápica & Bristol & Farmacêutico \\
\hline Silva Araújo-Roussel & grupo francês & Farmacêutico \\
\hline Endoquímica & Mead Johnson & Farmacêutico \\
\hline Lever & Gessy & Farmacêutico \\
\hline White Martins & Union Carbide & Vidro \\
\hline Hamers & Badische Anilin & Vidro \\
\hline Naegli & American Marietta & Vidro \\
\hline fábricas do grupo Paes de Almeida & grupo francês & Vidro \\
\hline Supergás & Gasbrás & Gás liquefeito \\
\hline
\end{tabular}

Fonte: Bandeira, 1975, p. 105. 
Na história das fusões e incorporações no país, há o registro de negócios, como os do setor automobilístico, representados na tabela III.2. Outros casos, ocorridos em diferentes setores, encontram-se relacionados na tabela III.3:

\section{III.1.3. O setor bancário nas décadas de 1960-1970}

No período 1964-1968, foi intensificada a concentração e a centralização no setor bancário. Nesse setor havia a necessidade de adequar a sua estrutura para conceder financiamentos com prazos superiores a 120 dias, para ampliar o consumo de bens duráveis, o que seria possível com o fortalecimento das instituições ${ }^{72}$. $\mathrm{O}$ incentivo às fusões e incorporações visava: aumentar a escala de produção, reduzir custos, aperfeiçoar a eficiência das empresas, tornar mais competitiva a empresa privada nacional e aumentar sua influência na economia do país. As 477 matrizes de bancos comerciais em 1940, foram reduzidas para 328 em 1964, 280 em 1968 e 117 em 1974 (sendo 80 de capital nacional privado e 8 de capital estrangeiro) (Bandeira, p. 85).

À época, a legislação brasileira dificultava a participação estrangeira no setor, pois para operar no mercado nacional o banco estrangeiro precisava obedecer aos critérios estabelecidos pelo Banco Central e obedecer à lei brasileira (era necessário possuir no país a sede administrativa), o que não impedia a abertura de escritórios de representação. Esses aumentaram de 100, em 1973, para 117 em 1974, a fim de operar sobretudo na intermediação de empréstimos e financiamentos às indústrias, relacionados principalmente à aquisição de máquinas e equipamentos em seus países de origem. Entretanto, se o Banco Central considerava a participação de estrangeiros apenas em oito bancos, em três desses bancos, Francês e Brasileiro (Crédit Lyonnais), Cidade de São Paulo (Dow Chemical Co.) e Mitsubish, os capitais estrangeiros dominavam, enquanto numa escala menor, havia a participação estrangeira no Banco América do Sul (14,3\% do capital), Halles (8,1\%, antes da incorporação ao Banco do Estado da Guanabara), Comércio e Indústria do Rio de Janeiro (10\%), União de Bancos (5,6\%) e Banco do Estado de São Paulo (0,2\%). Em outros bancos a participação estrangeira seria superior a 50\%: International (Bank of America/Bank of

\footnotetext{
${ }^{72}$ No Brasil, de acordo com Pécora (1972b), o setor bancário foi um dos primeiros a merecer a atenção das autoridades governamentais.
} 
Canadá), Banco Lar Brasileiro (Chase Manhattan Bank), Banco Francês e Italiano (Sudameris), mas no Sumitomo Brasileiro e no Banco de Tokyo a participação era de $100 \%$ (Bandeira, p. 84-87).

No período compreendido, houve um movimento de fusões e aquisições no país, principalmente através do incentivo dado pelo governo aos negócios ${ }^{73}$. Um exemplo foi o da anunciada fusão, em 1972, entre o Banco Brasileiro de Descontos e o União de Bancos Brasileiros (atuais Bradesco e Unibanco, respectivamente), fusão que terminou não prosperando, pois não houve acordo com relação ao comando da nova instituição, apesar do interesse do governo no negócio. Muitos dos bancos da época continuam em operação no país, como o Itaú, por exemplo, que cresceu através de incorporações. Também o Bradesco, antes do anúncio da frustrada fusão com o Unibanco, já havia incorporado cerca de oito instituições, de forma que o recente movimento de fusões e incorporações no setor, durante a década de 1990, não constitui propriamente uma novidade ${ }^{74}$. Uma diferença fica por conta das características das transações: nos anos 1960-1970, o regime militar incentivava transações entre instituições de capital nacional, em uma estratégia de consolidação do capital financeiro nacional, ao passo que da metade da década de 1990 em diante, o governo abriu o mercado à participação estrangeira.

\section{III.1.4. Privatizações na década de 1980}

Entre 1980 e 1989, no Brasil, 39 empresas foram privatizadas, 4 foram fechadas, 10 foram incorporadas, além de outras que sofreram modificações na sua constituição, foram arrendadas, tiveram suas atividades limitadas ou abriram o capital. No período compreendido entre 1980 e 1989, foram arrecadados US\$ 736 milhões com a privatização ${ }^{75}$. Também ocorreu a transferência de dívidas no valor de US\$ 600 milhões para o setor privado. Essas privatizações foram realizadas majoritariamente no âmbito do setor siderúrgico, sob

\footnotetext{
${ }^{73}$ Pécora (1972b), apontava a "quase total inexistência" do processo de fusão entre empresas no Brasil, mas referia-se a três negócios de alcance internacional: a fusão das empresas de energia elétrica do Estado de S. Paulo (que formou a CESP), a fusão das empresas ferroviárias, que criou a Rede Ferroviária Federal e a formação do Banco Itaú-América, resultantes "da preocupação do governo, no aspecto de unir para ser mais eficiente...", enquanto Rasmussen (1991) ressalta o estímulo dado pelos governos militares, no Brasil, à formação de grandes grupos, com base nas técnicas de consolidação das holdings norte-americanas (p. 57).

${ }^{74}$ Folha de S. Paulo, 19/04/1998.

${ }^{75}$ Conforme Cano, 1999, p. 220.
} 
responsabilidade da holding estatal Siderbrás. Siderúrgica Mogi das Cruzes (Cosim), Companhia de Ferro e Aço de Vitória (Cofavi) e Usina Siderúrgica da Bahia (Usiba), foram algumas das empresas privatizadas, além de outras empresas que se encontravam sob intervenção do BNDES ${ }^{76} 77$.

Quando do início do governo de José Sarney, o endividamento total da holding Siderbrás girava em torno de US\$ 17 bilhões. Já no início de 1990, o endividamento havia diminuído para cerca de US\$ 12 bilhões. No ano de 1989, apenas a Companhia Siderúrgica Paulista - CSN, teve um prejuízo de US\$ 205 milhões. As demais empresas apresentaram lucros: Companhia Siderúrgica Paulista - Cosipa, lucro de US\$ 50 milhões; Usiminas, lucro de US\$ 190 milhões; Companhia Siderúrgica de Tubarão - CST, lucro de US\$ 116 milhões e Açominas, lucro de US\$ 10 milhões $^{78}$. A Cosipa superou um prejuízo de US\$ 433 milhões em 1988 e apresentou lucros no ano seguinte, um resultado que não contou com recursos da Seplan, que atrasaram, e se fossem contabilizados aumentaria os lucros da empresa. Em um quadro de carência de recursos provenientes do governo, a empresa aliou-se a outras empresas para desenvolver alguns projetos: Armco Equipetrol e Mendes Jr., para a construção e instalação de sistema na Aciaria II; Instituto Nacional dos Distribuidores de Aço - Inda, para financiar laminador com capacidade de 100 mil toneladas; e com a Clecin (França), também para a instalação de outro laminador ${ }^{79}$.

Outro exemplo de privatização e reestruturação da década de 1980 é o da Radiobrás, que em dois anos (1987-1989) privatizou 34 de suas 40 emissoras de rádio e TV, demitiu 681 funcionários, incorporou a Empresa Brasileira de Notícias e vendeu 11 terrenos de sua propriedade $^{80}$. Por outro lado, não houve acordo para a privatização da Mafersa, em 1989, após a discordância dos funcionários em relação ao valor da privatização, incompatível com o patrimônio da empresa ${ }^{81}$.

Os dados apresentados por Schimidt (1997), evidenciam a dimensão das privatizações no Brasil. A venda de estatais na década de 1980, constituiu-se principalmente pela venda de empresas assumidas pelo Estado em função de dificuldades financeiras, mas apesar de

\footnotetext{
${ }^{76}$ O Estado de São Paulo, 09/03/1990.

77 “Apesar da idéia de privatização ganhar força a partir do governo Figueiredo, até 1989 só empresas marginais são privatizadas, em geral aquelas que foram assumidas pelo Estado em função das dificuldades financeiras, ou seja, uma operação de reprivatização" (Schmidt, 1997, p. 197).

${ }^{78}$ O Estado de S. Paulo, 17/01/1990.

${ }^{79} \mathrm{O}$ Estado de S. Paulo, 13/02/1990.

${ }^{80}$ O Estado de S. Paulo, 13/03/1990.

${ }^{81}$ O Estado de S. Paulo, 17/02/1990.
} 
resistências à saída do Estado desse setor estratégico, as empresas estavam sendo saneadas financeiramente. A privatização durante o período 1991-1993 rendeu US\$ 6.330 milhões. Desse montante, 64,7\% refere-se à privatização das companhias siderúrgicas (p. 197).

Schimidt (1997) compara as formas de pagamento das privatizações nos dois períodos:

- No primeiro período, o prazo dos pagamentos foi superior a 6 anos em $96 \%$ dos casos, com taxa de juros inferior a $12 \%$, correção monetária e pagamento à vista de menos de $30 \%$ do valor da compra em $84 \%$ dos casos (p. 197).

- No segundo período, além dos financiamentos do BNDES, foram utilizadas "moedas podres" 82 , de forma que dinheiro vivo corresponde a apenas $3 \%$ do valor de venda das empresas (p. 197).

A proposta de Rangel (1983) para a superação da crise econômica brasileira sugeria uma "mudança na distribuição dos papéis, entre o Setor Público e o Setor Privado", nos seguintes termos: 1) “o Setor Público perderá parcela importante dos serviços de utilidade pública, que retém como empresas públicas, e que serão reestruturados como concessões de serviço público a empresas privadas”, e 2) "o Setor Privado perderá importantes posições no campo do comércio exterior, o qual será, em grande parte, reestruturado como serviço planificado de Estado" (p.15). É importante destacar a proposta de concessão idealizada por Rangel (1983), no início da década, e que terminou por ser alterada, transformando-se na entrega de um patrimônio, o que de forma alguma era a intenção de seu autor, como demonstrado em Pizzo (1997).

Assim, parece haver uma diferença entre a iniciativa surgida ao final do regime militar e continuada no governo de José Sarney, ou seja, da desestatização da década de 1980, do processo constituído no decorrer da década de 1990, muito diferente dos projetos e debates que o originaram.

\footnotetext{
${ }^{82}$ Assim eram chamados os "títulos da dívida pública de longo prazo não pagos no vencimento - como as TDAs (Títulos da Dívida Agrária utilizados na privatização da Usiminas), debêntures da Siderbrás, letras hipotecárias da CEF (utilizada para saldar dívidas do Fundo de Compensação de Variações Salariais) - e aceitos pelo seu valor de face nos processos de privatização, sendo o seu valor de mercado bem inferior àquele" (Sandroni, 2002, p. 408). Outra definição afirma o seguinte: "O nome 'moedas podres' foi dado pelo mercado aos títulos de dívidas públicas que foram usados para pagar grande parte das privatizações federais. Eles ganharam esse nome por valerem no mercado menos que o valor real impresso no papel" (Folha de S. Paulo, 18/12/97)
} 
No primeiro caso, na década de 1980, as privatizações ocorreram em empresas deficitárias, de atuação local ou regional, ao contrário do processo de privatização instaurado a partir de 1990.

Ademais, em relação ao segundo período, conforme Biondi (1999), o balanço das privatizações realizado pelo governo federal, contabilizava uma arrecadação da ordem de $\mathrm{R} \$$ 85,2 bilhões, entretanto as "contas escondidas" não revelavam $\mathrm{R} \$ 87,6$ bilhões que não teriam entrado ou então que saíram dos cofres do governo. Para Biondi (1999), o Brasil teria “torrado" (sic) suas estatais, sem qualquer redução na dívida interna (p. 41$)^{83}$.

\section{III.2. Análise dos anos 1990}

\section{III.2.1. Introdução}

A década de 1990 caracteriza-se, conforme diversos autores, pelo crescimento de transações entre empresas, principalmente através de aquisições, fusões, parcerias, joint ventures, entre outros tipos de combinações. Triches (1996) assinala o crescimento e o dinamismo desses negócios no Brasil e a intensificação desse processo no âmbito internacional. Comin (1996) observa a ampliação sem precedentes da concentração, resultante das fusões e aquisições. Gonçalves $(1999,2000,2003)$ ressalta o envolvimento das empresas de capital estrangeiro em 59\% dos negócios no Brasil entre 1993 e 1997, quando a desnacionalização foi excepcional na economia brasileira, e a conseqüente subordinação do capital privado nacional. Bonelli (2000a) identifica a importância crescente das fusões e aquisições na década "em escala global" (p. 65). Ferraz \& Iootty (2000) consideram indiscutível a importância econômica desse processo, enquanto Miranda \& Martins (2000) falam em crescimento continuado das fusões e aquisições de empresas, com tendência da concentração e centralização do capital.

A despeito das diversas possibilidades de caracterização da década, diante do aumento do número de transações entre empresas, e algo mais importante do que a quantidade de negócios realizados, o que por si só já é relevante, seja em âmbito nacional ou internacional,

\footnotetext{
${ }^{83}$ Confirmando Biondi, Lesbaupin e Mineiro (2002) afirmam: "A inutilidade da privatização para a redução do déficit público se confirma quando se olham os valores das dívidas: tanto a dívida externa como a dívida interna cresceram assustadoramente. Um dos argumentos que justificavam a privatização - reduzir o déficit público -, portanto, não se confirmou" (Lesbaupin e Mineiro, 2002, p. 30-31).
} 
deve-se destacar as causas do movimento. Comin (1996) considera as privatizações e a desregulação de mercados como causadores do processo. Triches (1996) aponta causas diversas, tais como a retração do mercado, as reformas realizadas pelo governo e mudanças tecnológicas, especialmente em torno dos segmentos: defesa, remédios, assistência e saúde, mídia e telecomunicações. Ferraz \& Iootty (2000) apresentam uma análise das causas baseada na idéia de que as fusões e aquisições fariam parte da globalização, a partir da aceleração internacional dos fluxos tanto de bens, serviços, tecnologia e capital, além da intensificação das transformações tecnológicas e de mudanças nos "regimes nacionais de incentivos e regulação, na direção da liberalização econômica" (p. 39). Os determinantes das fusões e aquisições para Gonçalves (2000) seriam a busca por maior sinergia, “diversificação de risco; padrões de concorrência; reestruturação produtiva; acesso à tecnologia; desregulamentação; privatização; incentivos fiscais; percepção gerencial; e estratégia de crescimento" (p. 82). Para Rossetti (2001), o aumento das fusões e aquisições no Brasil, nos anos 1990, seria uma decorrência das "mudanças da orientação estratégica da economia nacional ocorridas no mesmo período" (p. 67).

Diversas transformações econômicas e institucionais ocorridas no Brasil, durante a década de 1990 causaram a abertura comercial, o fim da reserva de mercado de vários setores, desregulamentações nas esferas da produção e do trabalho, e o aumento exponencial das transações entre empresas, através do movimento de fusões e aquisições e também pelo processo de privatizações realizado pelo governo federal e pelos governos estaduais no decorrer da década; tais modificações trouxeram sérias consequiências para o país, como o aumento do desemprego e o correspondente declínio dos índices de crescimento econômico.

A concentração e a centralização de capitais intensificou-se no país a partir de 1990, com a abertura do mercado interno e a adoção de medidas econômicas neoliberais. Conforme indica Gonçalves (1999), é preciso considerar, nessa abordagem, os fluxos de investimentos externos e o processo de desnacionalização.

A tendência a cartelização do mercado está associada aos períodos de crise da economia capitalista, seja por aquisições e fusões ou por eliminação de concorrentes em um mesmo mercado. Também a verticalização ou a horizontalização da cadeia de produção representam movimentos de incorporação ou desinvestimento mais acentuados nos períodos de crise, em oposição ao crescimento em escala, com a ampliação do número de plantas nas fases de expansão do capitalismo. Contudo, em mercados monopolizados ou oligopolizados, a 
tendência de contenção dos investimentos em inovações possibilitam o surgimento de novos competidores baseados na aplicação de novas tecnologias em produtos e processos. A ascensão das empresas japonesas no mercado internacional, no pós-guerra, fragilizou vários setores cartelizados como siderúrgico, automotivo, eletro-eletrônico, informática, etc. (Mamigonian, 1982), exigindo nova reorganização da produção nas escalas nacional, regional e mundial.

\section{III.2.2. Causas das fusões e aquisições e intensificação dos investimentos estrangeiros}

Para Rossetti (2001), as fusões e aquisições aumentaram, no Brasil dos anos 1990, por causa das transformações ocorridas na estrutura macroeconômica do país, associadas principalmente à:

(...) estabilização monetária, o fim do longo ciclo de hiperinflação, as reformas constitucionais de direção liberalizante, a desregulamentação de mercados, a flexibilização das relações econômicas internacionais e a disposição em atrair capitais externos para investimentos produtivos somaram-se aos mais recentes fundamentos estratégicos e implicaram um novo modelo de inserção do país na emergente economia globalizada (Rossetti, 2001, p. 70).

Gonçalves (2000), defende que o Brasil caracteriza-se historicamente por possuir uma economia aberta, e receber com grande freqüência investimentos externos diretos, constituindo-se em "uma das economias mais abertas do mundo", em uma análise que considera a "inserção passiva" do país na economia internacional (p. 79). Entretanto, é preciso ressaltar que o capital estrangeiro foi um componente importante do processo de industrialização brasileiro, concentrando-se em alguns setores da economia, sem participar de toda a cadeia de produção.

Pode-se ressaltar que a afirmação de Gonçalves caracteriza de forma precisa o Brasil da década de 1990, a partir da implementação da abertura econômica que ocasionou maior dependência dos fluxos financeiros internacionais, maior endividamento interno e externo, queda do PIB, maior desemprego, e o aumento da desnacionalização da economia, entre outras conseqüências da ensejada modernização do país. A constatação refere-se ao mais “amplo e profundo processo de desnacionalização da história econômica do país" (p. 79). 
Gonçalves considera o aumento da participação estrangeira no valor bruto da produção, de 13,5\% em 1995 para 24,6\% em 1999, além de ter aumentado, também, a participação do capital estrangeiro no valor das vendas das 550 maiores empresas, de 33,3\% em 1995 para 43,5\% em 1998, pois das 500 maiores empresas privadas no Brasil, 144 eram estrangeiras em 1995, número que aumentou para 170 em 1997, e para 209 em 1998. Teria ocorrido um "salto quântico" na desnacionalização da economia brasileira, a partir de 1995. Houve, ainda, queda da "participação das empresas de capital privado nacional", de 44\% em 1994, para 39,4\% em 1998. Pelo lado das empresas estatais, sua participação saltou de $24 \%$ em 1994, para 17,1\% em 1998 e, conclui que este processo de desnacionalização teria sido “inusitado na história da economia brasileira", além de ter sido enfraquecido o capital nacional e fortalecidos os grandes grupos estrangeiros (Gonçalves, 2000, p. 79-80) ${ }^{84}$.

Seriam quatro os fatores para o aumento do capital estrangeiro no Brasil:

I. crescimento dos fluxos de investimento direto;

II. fusões e aquisições em escala global;

III. mudanças no aspecto regulatório (liberalização e desregulamentação) e

IV. as privatizações.

Para Gonçalves (2000), os fatores 1 e 2 seriam exógenos, enquanto 3 e 4 seriam endógenos (p. 80).

É preciso assinalar, portanto, que o movimento de fusões e aquisições, bem como os processos de privatização realizados na década, não ocorreram isoladamente ou à margem de decisões e políticas governamentais, cujos pressupostos, passíveis de críticas e questionamentos, certamente não foram os mesmos em todos os países.

Conforme Gonçalves, a "relação entre o fluxo de investimento externo direto e a formação de capital fixo aumentou de 2,5\% em 1995 para 24,6\% em 1999”, resultando em um aumento do controle do estoque de capital fixo pelas empresas estrangeiras, da ordem de 6,8\% em 1995 para 12,4\% em 1999. A participação estrangeira aumentou também no “estoque líquido de riqueza", de 5,7\% em 1995, para 9,7\% em 1999. A partir de 1995 houve aumento do investimento externo direto (IED) no país, o que contribuiu para o Brasil passar

\footnotetext{
84 "Imaginar que a entrada de capital estrangeiro representa um endosso da política do governo é, na melhor das hipóteses, uma demonstração de ignorância acerca da dinâmica do investimento externo direto, seus fatores determinantes, e sua história recente no Brasil e no mundo" (Gonçalves, 2000, p. 80).
} 
da $16^{\text {a }}$ posição em recebimento de IED em 1994, para a $5^{\text {a }}$ posição no período 1997-98 (p. 80).

A tendência de crescimento de IED encontra-se associada à intensificação das transações relativas às fusões e aquisições em todo o mundo. $\mathrm{O}$ IED aumentou de aproximadamente US\$ 329 bilhões em 1995, para cerca de US\$ 644 bilhões em 1998, assim como ocorreu o aumento do número de fusões e aquisições transfronteiriças, de US\$ 141 bilhões em 1995 para US\$ 411 bilhões em 1998. No Brasil o crescimento das fusões e aquisições também foi significativo, passando de US\$ 1 bilhão, em 1995, para cifras superiores a US\$ 21 bilhões em 1998. As privatizações ocorridas no país foram responsáveis por " $25 \%$ do valor total do ingresso bruto de IED no período 1995-1999", o que teria causado a desnacionalização e concentração de capital através da "inserção passiva do país na economia mundial" (Gonçalves, p. 81).

Para Rossetti (2001) a década de 1990 representa um "novo enquadramento estratégico", realizado nos moldes da reengenharia dos negócios, importante por ter propiciado transformações no modelo empresarial brasileiro, com modificações diárias na competição entre os mercados. Dentre as reengenharias adotadas, predominaram as aquisições e as fusões. Menciona, entre as causas desse novo ciclo, o processo de privatizações, que inverteu a tendência anterior, "do crescimento do Estado empresário ao desengajamento empresarial do Estado", (p. 71-74) período em que foi definido o Programa Nacional de Desestatização - PND.

Rossetti mostra o aumento da evolução mundial dos investimentos estrangeiros diretos, apresentando dados referentes ao destino dos fluxos de investimento em todo o mundo, de 1984 até o final da década de 1990: cerca de US\$ 237 bilhões no período 1984-89; US\$ 485 bilhões no período 1990-95; US\$ 739 bilhões no período 1996-99 e previsão da ordem de US\$ 1 trilhão no qüinqüênio 2000-2004, com aproximadamente $75 \%$ deles destinados a fusões e aquisições e o restante para novos projetos (p. 71).

Note-se no gráfico III.1, a evolução crescente dos investimentos estrangeiros diretos no mundo todo, em fusões e aquisições, e de maneira proporcionalmente inversa os investimentos em novos projetos.

Enquanto em 1991 os números são parecidos, a partir de 1992 isso deixa de ocorrer, pois enquanto aumenta a quantidade das fusões e aquisições, os investimentos em novos 
projetos passam a ser decrescentes, priorizando-se a aquisição de empreendimentos já estabelecidos, ao contrário de investimentos em máquinas, equipamentos, imóveis, etc..

Em 1998 o volume de investimentos externos diretos no país, foi da ordem de US\$ 20 bilhões, excetuando-se os recursos voltados para as privatizações; em 1999 esses investimentos alcançaram US\$ 21 bilhões. Considerando-se os recursos voltados para as privatizações, as cifras alcançaram em 1998, US\$ 28 bilhões, e em 1999, US\$ 30 bilhões.

Gráfico III.1

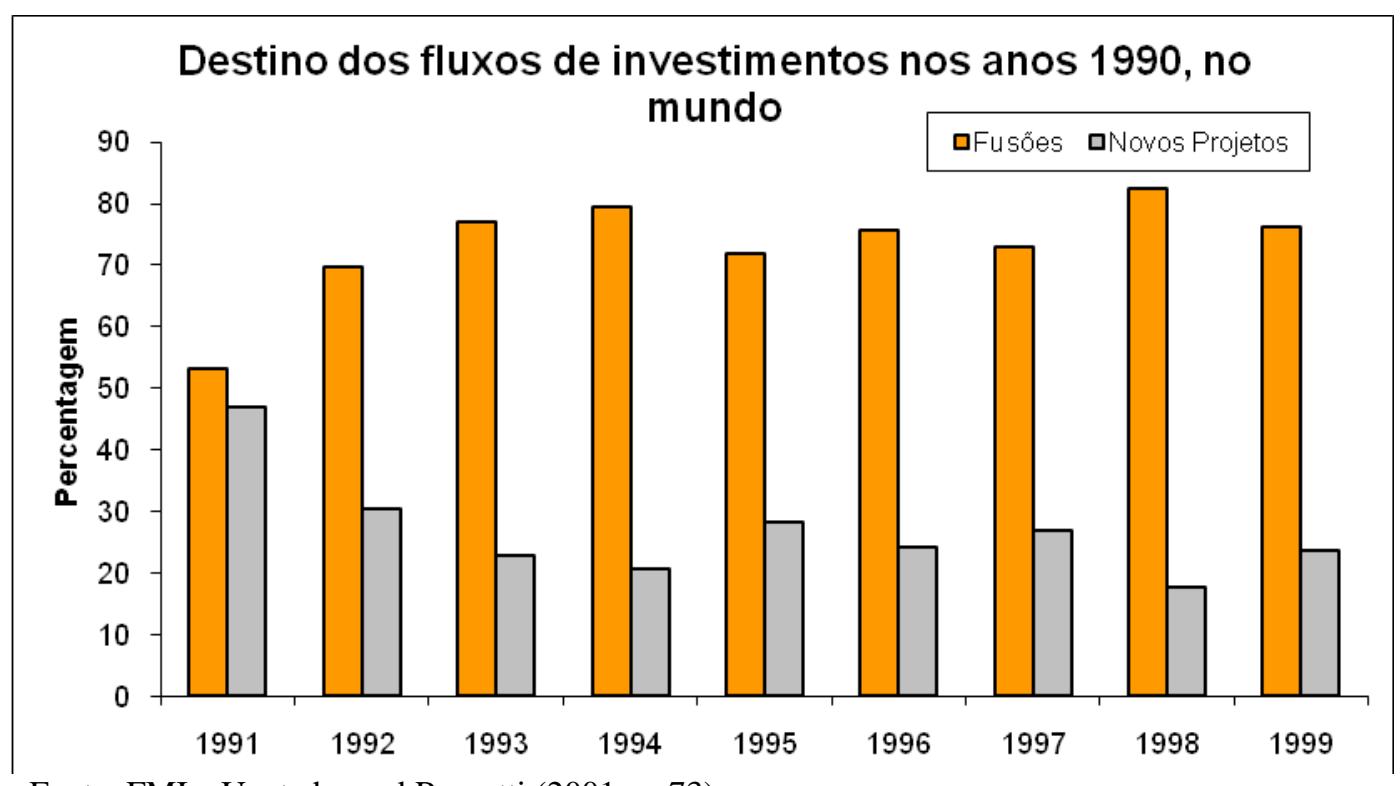

Fonte: FMI e Unctad, apud Rossetti (2001, p. 73)

Em 2000, a Sociedade Brasileira de Estudos de Empresas Transnacionais-SOBEET, calculava os investimentos diretos estrangeiros no país em níveis superiores aos índices de investimentos dos anos anteriores, em aproximadamente US\$ 25 bilhões. De tais valores, previa-se US\$ 2,5 bilhões para a compra de empresas estatais, excluindo-se desse cálculo, naquele ano, a venda do Banco do Estado de São Paulo - BANESPA. Assim, restariam US\$ 22,5 bilhões que se voltariam principalmente para fusões e aquisições de empresas, portanto, um valor ao redor de US\$ 1,5 bilhão superior ao do ano anterior, considerando este um investimento "recorde", excetuando-se os valores das privatizações, mas que apontava, por outro lado, um decréscimo dos investimentos nas privatizações ${ }^{85}$.

${ }^{85}$ O Estado de S. Paulo, 24 e 25/07/00. 
Tabela III.4:

\section{NÚMERO DE TRANSAÇÕES E PORCENTAGEM (EM MILHÕES US\$), SEGUNDO O TIPO DE COMPRADOR, 1990-1999 (BRASIL)}

\begin{tabular}{|c|c|c|c|c|c|c|c|c|}
\hline $\begin{array}{l}\text { Empresa } \\
\text { de Con }\end{array}$ & $\begin{array}{l}\text { Tipo } \\
\text { dor }\end{array}$ & $\begin{array}{l}\frac{\pi}{0} \\
\frac{\pi}{\pi} \\
\frac{\pi}{n}\end{array}$ & 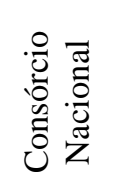 & 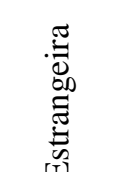 & 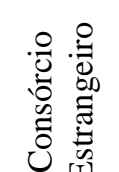 & $\stackrel{\stackrel{0}{:}}{\stackrel{\mathscr{n}}{\Sigma}}$ & 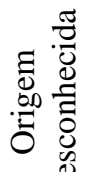 & $\stackrel{5}{0}$ \\
\hline 1990 & $\mathbf{N}^{\mathbf{0}}$ & 421 & 0 & 217 & 0 & 0 & 0 & 639 \\
\hline 1990 & $\%$ & 65,9 & 0,0 & 34,0 & 0,0 & 0,0 & 0,0 & 100,0 \\
\hline & $\mathbf{N}^{\mathbf{o}}$ & 1.286 & 0 & 158 & 0 & $\mathbf{0}$ & 97 & 1.541 \\
\hline 1991 & $\%$ & 83,5 & 0,0 & 10,3 & 0,0 & 0,0 & 6,3 & 100,0 \\
\hline 1992 & $\mathbf{N}^{\mathbf{0}}$ & 433 & 1.826 & 166 & 0 & 0 & 388 & 2.814 \\
\hline 1992 & $\%$ & 15,4 & 64,9 & 5,9 & 0,0 & 0,0 & 13,8 & 100,0 \\
\hline & $\mathrm{N}^{\mathbf{0}}$ & 2.802 & 982 & 629 & 1 & 482 & 16 & 4.914 \\
\hline 1993 & $\%$ & 57,0 & 20,0 & 12,8 & 0,0 & 9,8 & 0,3 & 100,0 \\
\hline & $\mathbf{N}^{\mathbf{0}}$ & 551 & 422 & 332 & 35 & O & 135 & 1.475 \\
\hline 1994 & $\%$ & 37,4 & 28,6 & 22,5 & 2,4 & 0,0 & 9,2 & 100,0 \\
\hline & $\mathbf{N}^{\mathbf{0}}$ & 2.526 & 179 & 1.685 & 50 & 63 & 0 & 4.502 \\
\hline 1995 & $\%$ & 56,1 & 4,0 & 37,4 & 1,1 & 1,4 & 0,0 & 100,0 \\
\hline 1006 & $\mathbf{N}^{\mathbf{o}}$ & 2.762 & 323 & 4.123 & 1.860 & 64 & $\mathbf{0}$ & 9.131 \\
\hline 1990 & $\%$ & 30,2 & 3,5 & 45,2 & 20,4 & 0,7 & 0,0 & 100,0 \\
\hline & $\mathrm{N}^{\mathbf{0}}$ & 10.476 & 3.382 & 8.501 & 1.830 & 1.182 & 0 & 25.372 \\
\hline 1997 & $\%$ & 41,3 & 13,3 & 33,5 & 7,2 & 4,7 & 0,0 & 100,0 \\
\hline 1998 & $\mathbf{N}^{\mathbf{0}}$ & 6.136 & 4.175 & 26.215 & 5.673 & 8.455 & 20 & 50.674 \\
\hline & $\%$ & 12,1 & 8,2 & 51,7 & 11,2 & 16,7 & 0,0 & 100,0 \\
\hline 1000 & $\mathrm{~N}^{\mathbf{0}}$ & 3.310 & 93 & 11.391 & 1.410 & 110 & 0 & 16.314 \\
\hline 1999 & $\%$ & 20,3 & 0,6 & 69,8 & 8,6 & 0,7 & 0,0 & 100,0 \\
\hline & $\mathrm{N}^{\mathbf{0}}$ & 30.704 & 11.382 & 53.418 & 10.859 & 10.356 & 656 & 117.374 \\
\hline Tot & $\%$ & 29,9 & 4,0 & 59,7 & 2,7 & 2,3 & 1,4 & 100,0 \\
\hline
\end{tabular}

Fonte: Ferraz e Iooty (2000, p. 52).

Conforme se observa na tabela III.4, a participação estrangeira em transações no Brasil foi maior que as transações domésticas nos anos de 1996,1998 e 1999, ou seja, durante o governo Fernando Henrique Cardoso. O interesse do governo, em 1999, direcionava-se para a captação externa, o que acarretou a queda da vantagem competitiva das empresas nacionais diante das privatizações, fusões e aquisições ${ }^{86}$.

\footnotetext{
${ }^{86}$ O presidente da CPFL - única empresa de capital $100 \%$ nacional a se pré qualificar para o leilão da Cesp Paranapanema e Cesp Tietê - Jean Degen, expressa assim seu descontentamento: "A situação mais perversa é que o governo brasileiro não está interessado em estimular as empresas de capital nacional nas privatizações. Afinal, se uma empresa brasileira compra outra, não entra dinheiro no País. Do jeito que está, nunca vou conseguir ganhar de um estrangeiro." (Gazeta Mercantil, 08/09/1999).
} 
Os dados coletados pela KPMG, arrolados no gráfico III.2, diferenciam o percentual de participação dos negócios domésticos daqueles realizados com participação estrangeira, e indicam a evolução de uma tendência para as duas variáveis. O gráfico apresenta os percentuais contidos na tabela III.5 e destaca a participação estrangeira. Enquanto representação da década, mostra não apenas como evoluiu a participação estrangeira, mas principalmente como essa participação ocorreu em detrimento das empresas brasileiras.

Gráfico III.2

\section{Transações realizadas no Brasil - 1992-2004 (em \%)}

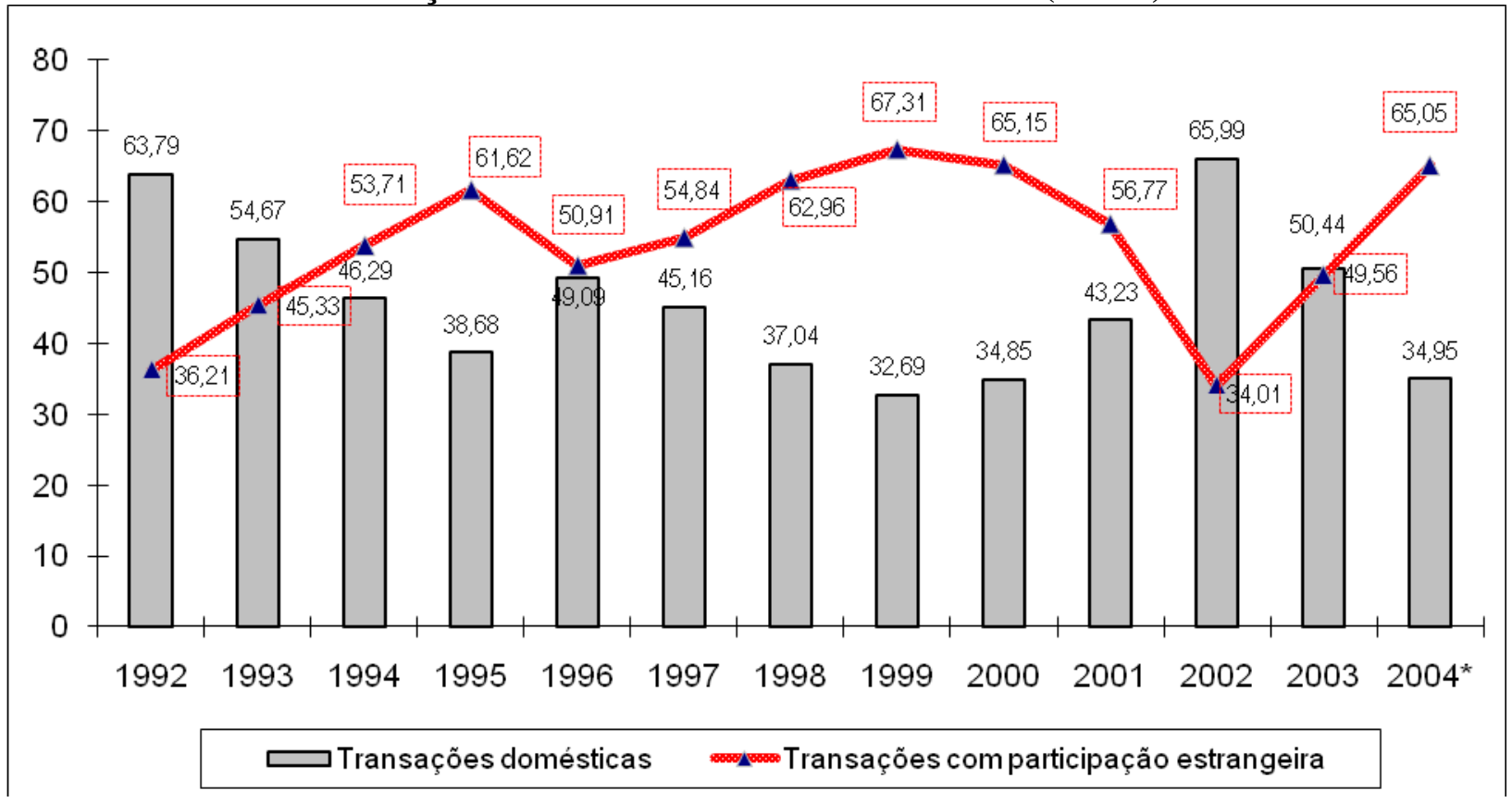

Fonte: KPMG Corporate Finance, Pesquisa de Fusões \& Aquisições, 1998, 2003 e 2004 . Elaboração própria.

* Dados referentes aos nove primeiros meses do ano corrente.

A participação estrangeira nas aquisições de empresas no Brasil, para o período 19932000, revela os seguintes dados: EUA (34\%); França (9\%); Reino Unido (5\%); Alemanha (5\%); Argentina (5\%); Itália (4\%); Portugal (3\%), Espanha (3\%), etc.

A maior parte dos negócios realizados no Brasil concentra-se nas áreas mais industrializadas, São Paulo à frente, com 45,4\% das transações, seguido por Rio de Janeiro $(12,8 \%)$, Minas Gerais (7,2\%), Rio Grande do Sul (6,6\%), etc. Todos os dados apresentados foram gerados pela $K P M G$, e referem-se apenas as quantidades de transações realizadas. 


\section{III.2.3. Transações dos anos 1990 - pesquisas e análises de consultorias}

A) Com relação ao número de transações, foi divulgado que a maior parte desses investimentos seria direcionada para os novos setores da economia, relacionados às empresas de informática, internet e telecomunicações, ao contrário dos anos anteriores, quando se concentraram nos setores tradicionais da economia (autopeças, têxteis e produtos farmacêuticos, etc.). Efetivamente, muitos negócios movimentaram o setor de tecnologia da informação, como, entre outros, a aquisição do Pontocom, a nona aquisição realizada no país e a quarta no estado do Rio de Janeiro, após as aquisições dos provedores Open Link, Domain e GlobalNet, realizadas pela provedora de acesso PSInet logo no início do ano $2000^{87}$. Em agosto do mesmo ano, a consultoria PriceWaterhouseCoopers $(P w C)$ contabilizava 365 transações realizadas no Brasil, com o setor de internet liderando em $25 \%$ das transações, enquanto o setor de serviços públicos, entre eles energia elétrica, telefonia, água e esgoto, e gás, totalizavam $10 \%$ dos negócios, e cada um desses setores - mineração, bancos e alimentos - representaram 7\% dos negócios, sendo que os demais setores da economia totalizaram $44 \%$ do restante das transações alcançando, individualmente, de $1 \%$ a $3 \%{ }^{88}$.

A partir dos dados apontados pela KPMG Corporate Finance, coletados desde 1992, são discutidos os negócios firmados entre empresas nacionais ("transações domésticas") e os negócios realizados com participação estrangeira, ou trans-fronteiriços (denominados "cross border” pela KPMG), representados pela tabela III.5.

\footnotetext{
${ }^{87}$ O Estado de S. Paulo, 03/05/00.

${ }^{88}$ O Estado de S. Paulo, 08/08/00.
} 
Tabela III.5:

Total de Transações (domésticas e participação estrangeira)

\begin{tabular}{|c|c|c|c|c|c|}
\hline \multirow[t]{2}{*}{ ANO } & \multicolumn{2}{|c|}{ TRANSAÇÕES DOMÉSTICAS } & \multicolumn{2}{|c|}{ PARTICIPAÇÃO ESTRANGEIRA } & \multirow{2}{*}{$\begin{array}{l}\text { TOTAL } \\
\text { GERAL }\end{array}$} \\
\hline & $\mathbf{N}^{\mathbf{0}}$ & $\%$ & $\mathbf{N}^{\circ}$ & $\%$ & \\
\hline 1992 & 37 & 63,79 & 21 & 36,21 & 58 \\
\hline 1993 & 82 & 54,67 & 68 & 45,33 & 150 \\
\hline 1994 & 81 & 46,29 & 94 & 53,71 & 175 \\
\hline 1995 & 82 & 38,68 & 130 & 61,62 & 212 \\
\hline 1996 & 161 & 49,09 & 167 & 50,91 & 328 \\
\hline 1997 & 168 & 45,16 & 204 & 54,84 & 372 \\
\hline 1998 & 130 & 37,04 & 221 & 62,96 & 351 \\
\hline 1999 & 101 & 32,69 & 208 & 67,31 & 309 \\
\hline 2000 & 123 & 34,85 & 230 & 65,15 & 353 \\
\hline 2001 & 146 & 43,23 & 194 & 56,77 & 340 \\
\hline 2002 & 143 & 65,99 & 84 & 34,01 & 227 \\
\hline 2003 & 116 & 50,44 & 114 & 49,56 & 230 \\
\hline $2004 *$ & 72 & 34,95 & 134 & 65,05 & 206 \\
\hline Total & 1442 & 43,55 & 1869 & 56,45 & 3311 \\
\hline
\end{tabular}

Fonte: KPMG Corporate Finance, Pesquisa de Fusões \& Aquisições, 1998, 2003 e 2004. Elaboração própria.

* Dados referentes aos nove primeiros meses de 2004.

No período 1992-2004, os negócios realizados entre empresas brasileiras somaram 1442, enquanto aqueles realizados com participação estrangeira alcançaram 1869, em um total de 3311 transações (KPMG Corporate Finance, Pesquisa de Fusões \& Aquisições, 1998, 2003 e 2004). Os dados do período 1992-2004, apontam a maior quantidade de transações no setor de Alimentos, Bebidas e Fumo (337 negócios), seguido por Instituições Financeiras (239), Telecomunicações (238), Tecnologia da Informação (217), Metalurgia e Siderurgia (173), Produtos Químicos e Petroquímicos (153), Companhias Energéticas (148), Petrolífero (136), Publicidade e Editoras (133) e Seguros (121). Os demais setores não chegaram a atingir uma centena de negócios no período (Partes e peças automotivas: 97; Elétrico e eletrônicos: 91; Supermercados: 82, etc.) (vide tabela III.8).

O gráfico III.3 apresenta as transações realizadas no Brasil, e o aumento da participação estrangeira nos negócios, com seu auge em 1999, quando atingiu 67,31\% das transações, diminuindo posteriormente. Entretanto, o maior número de transações realizadas no país ocorreu em 1997, com 372 negócios, quando a porcentagem de participação estrangeira atingiu $54,84 \%$ das transações. $\mathrm{O}$ índice de participação estrangeira foi crescente 
até 2000, mesmo com a queda das transações no cenário nacional. Em todo o período, as transações com participação estrangeira alcançaram 56,45\%.

\section{Gráfico III.3}

Transações Domésticas e com Participação Estrangeira

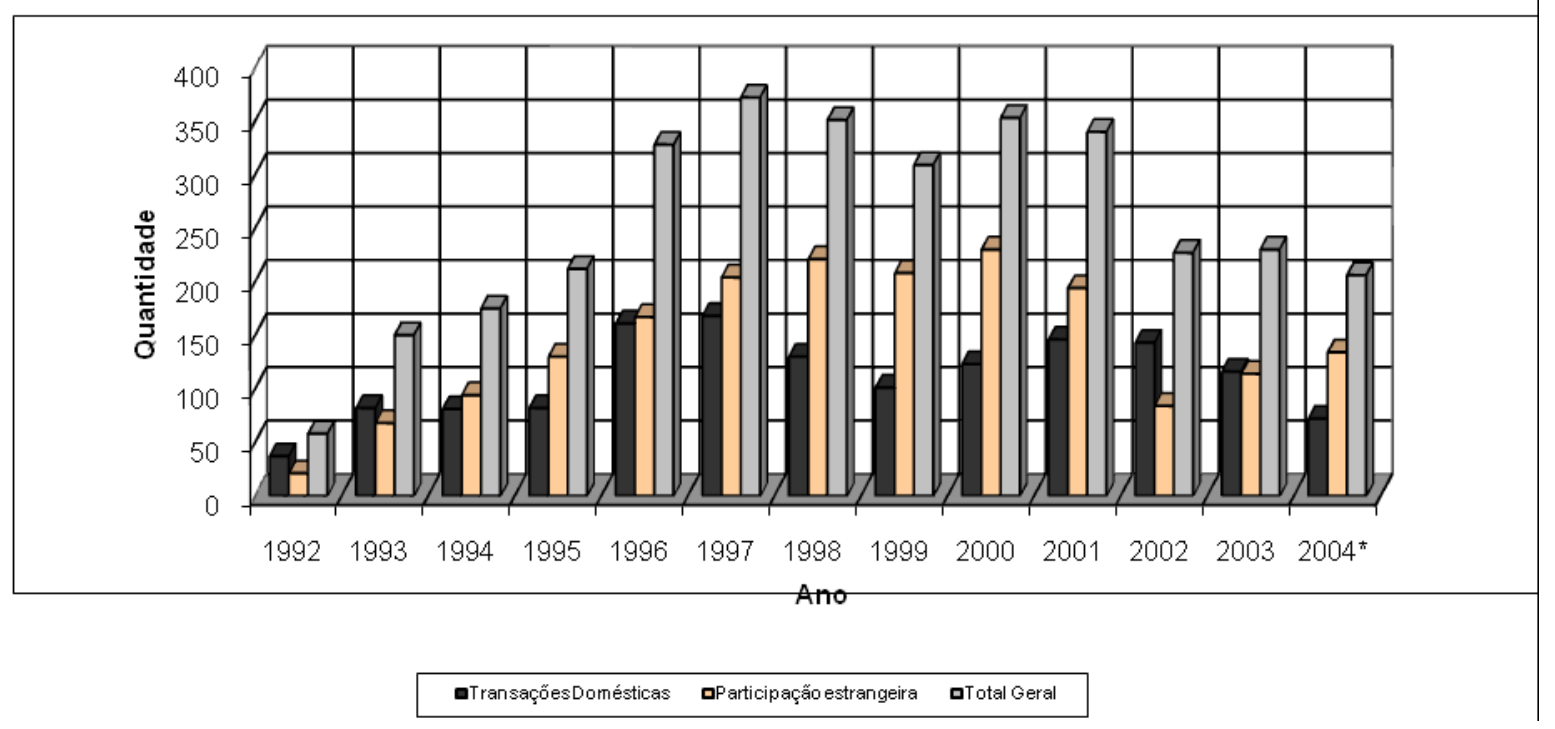

Fonte: KPMG Corporate Finance, Pesquisa de Fusões \& Aquisições, 1998, 2003 e 2004. Elaboração própria.

* Dados referentes aos nove primeiros meses do ano corrente.

A década inicia-se com transações relativamente modestas, com a supremacia das transações domésticas sobre as transações com participação estrangeira, nos anos de 19921993, e apontam pouca diferença em 1994, ano de criação do Plano Real. A partir de 1995, os negócios são crescentes até 1998 e 1999, quando ocorre uma queda nas transações domésticas. Nesse período, a participação das empresas estrangeiras nos negócios supera a quantidade de transações domésticas, atingindo seu maior número em 2000, quando as transações domésticas voltaram a crescer, diante de uma diminuição das participações estrangeiras em 2001 e 2002. Em 2002, as transações domésticas, após 8 anos, são maiores que as transações com participação estrangeira, ao final de um período em que se esgotou o processo de privatizações, após a venda das empresas estatais mais importantes. Cabe observar, ainda, que durante o governo de Fernando Henrique, as transações com participação estrangeira estiveram acima de $50 \%$ em sete dos oito anos de sua gestão, e foram superiores a $60 \%$ em quatro anos do mesmo período. 
B) Por outro lado, quando se agregam dados referentes aos valores das transações, os dados contabilizados no período 1990-1999, pela Thomson Financial Securities Data, demonstram: de um total de 1.149 transações referentes ao período, a Thomson disponibilizou os valores de 565 negócios. Nesses, a participação estrangeira foi majoritária, e obtiveram maior destaque os seguintes setores: telecomunicações; energia elétrica, gás e água; financeiro; metalurgia e siderurgia; e alimentar.

Esses cinco setores são os responsáveis por aproximadamente $75 \%$ do valor total das transações no período, e apenas os dois primeiros setores (telecomunicações; e energia elétrica, gás e água) concentram a metade do valor total das transações para o período, estimado em US\$ 117 bilhões. Ressalte-se que a maior parte das transações refere-se a privatizações relacionadas às infra-estruturas do país. Desse ranking, apenas no setor Metalurgia e Siderurgia a participação do capital estrangeiro não foi majoritária.

A tabela III.6, elaborada por Rossetti (2001), com base nos dados da Gazeta Mercantil e Fundação Dom Cabral, apresenta o total de transações realizadas no período 1990-1999:

Tabela III.6:

Fusões e aquisições no Brasil - 1990-1999

\begin{tabular}{cccc}
\hline & & \multicolumn{2}{c}{ Média anual acumulada } \\
\cline { 3 - 4 } Anos & Total de transações & Ano a ano & Taxa anual de variação \\
\hline 1990 & 186 & 186 & - \\
1991 & 184 & 185 & $-0,5$ \\
1992 & 252 & 207 & 11,9 \\
1993 & 245 & 217 & 4,8 \\
1994 & 218 & 218 & 0,1 \\
1995 & 260 & 224 & 2,8 \\
1996 & 349 & 242 & 8,0 \\
1997 & 401 & 262 & 8,3 \\
1998 & 363 & 273 & 4,2 \\
1999 & 325 & 278 & 1,8 \\
Período & $\mathbf{2 . 7 8 3}$ & $\mathbf{2 7 8}$ & $\mathbf{5 , 7}$ \\
\hline
\end{tabular}

Fonte: Rossetti (2001, p. 75)

Entretanto, entre as tabelas III.5 (pág. 90) e III.6, observa-se uma diferença entre os períodos pesquisados (1992-2004) para a KPMG e 1990-1999, para os dados de Rossetti (2001), o que causa uma diferença entre os totais, por causa dos períodos de abrangência. 
Miranda e Martins (2000), auferiram os bancos de dados da KPMG e da Securities Data, a fim de confrontar os dados e "averiguar o grau de interseção (e evitar dupla contagem) entre os dois conjuntos de informações" (p. 70). Assim, a finalidade da tabela III.7 é comparar os números de fusões e aquisições coletados por fontes distintas, e seu período de abrangência.

Tabela III.7

Comparação entre fontes sobre fusões e aquisições no Brasil

\begin{tabular}{lccccccccccc}
\hline \multicolumn{1}{c}{ Ano } & $\mathbf{1 9 9 0}$ & $\mathbf{1 9 9 1}$ & $\mathbf{1 9 9 2}$ & $\mathbf{1 9 9 3}$ & $\mathbf{1 9 9 4}$ & $\mathbf{1 9 9 5}$ & $\mathbf{1 9 9 6}$ & $\mathbf{1 9 9 7}$ & $\mathbf{1 9 9 8}$ & $\mathbf{1 9 9 9}$ & $\mathbf{2 0 0 0}$ \\
FDC/Rossetti & 186 & 184 & 252 & 245 & 218 & 260 & 349 & 401 & 363 & 325 & - \\
KPMG & - & - & 58 & 150 & 175 & 212 & 328 & 372 & 351 & 309 & 353 \\
Securities Data & - & 22 & 43 & 70 & 73 & 113 & 143 & 169 & - & - & - \\
Miranda e Martins & - & 22 & 62 & 130 & 157 & 214 & 307 & 270 & - & - & - \\
\hline
\end{tabular}

Fontes: KPMG, Rossetti (2001, p. 75) e Miranda e Martins (2000, p. 71). Elaboração própria.

Conforme se observa na tabela III.7, e em Miranda e Martins (2000), há diferenças no levantamento de dados entre autores e consultorias. Neste sentido, conservamos como principal fonte de dados a KPMG, por acompanhar as transações e publicar seus resultados a cada trimestre, e assim se aproximar da realidade, além de apresentar dados quantitativos por setores, períodos, participação estrangeira e unidades da federação (distribuição geográfica) ao longo de todo o período.

\section{III.2.4. Comparação de transações realizadas no Brasil}

Na tabela III.8 (pág. 96), verifica-se que no período 1992-1994 alguns setores não eram contabilizados pela pesquisa da KPMG, como "Tecnologia da Informação", "Publicidade e Editoras", "Produtos de Engenharia", "Lojas de Varejo", etc..

Outros setores não apresentaram negócios, como "Companhias Energéticas” (19921994), "Petrolífero" (1992), "Serviços para Empresas” (1992), “Transportes” (1992), “Cimento" (1992), “Aviação" (1992-1993), "Ferroviário" (1992-1994). A partir de 1995, a pesquisa retrata um aumento na quantidade de setores abrangidos pelas fusões e aquisições. 
Os dados da tabela III.8 foram agregados a partir das informações da KPMG, referentes a todos os setores pesquisados e acumulados no período de onze anos. Os dados encontram-se ordenados conforme o total de transações por setor, aparecendo em ordem decrescente. Dessa forma, no período 1992-2002, o setor com maior número de negócios foi o setor de Alimentos, Bebidas e Fumo (330), seguido por Instituições Financeiras (213), Telecomunicações (193), Tecnologia da Informação (168), Metalurgia e Siderurgia (150), Produtos Químicos e Petroquímicos (143), Companhias Energéticas (120), Petrolífero (117), Publicidade e Editoras (106) e Seguros (101). Os demais setores não alcançaram uma centena de negócios.

A década inicia-se com transações relativamente modestas (em quantidade, não em valores), com a supremacia das transações domésticas sobre as transações "cross border", nos anos de 1992-1993, e apontam pouca diferença em 1994, ano de criação do Plano Real.

A partir de 1995, os negócios são crescentes até 1998 e 1999, quando ocorre uma queda nas transações domésticas, e as transações "cross border" superam as transações domésticas, atingindo maior participação em 2000.

Nesse período foram vendidas grandes empresas ao capital estrangeiro, como ocorreu com a Metal Leve (vendida para a alemã Mahle, em associação com a Cofap, em 1996); Cofap (vendida para a italiana Magneti Marelli, em 1997); Freios Varga (para o grupo inglês Lucas Variety, em 1997); Arno (vendida ao grupo francês SEB, em 1997); Brasmotor (para a norte-americana Whirlpool, em 1997); Agroceres, (para a Monsanto, em 1997); rede de Supermercados Eldorado (ao francês Carrefour, em 1997); Quartzolit (para o grupo Saint Gobain, em 1997); Gevisa Locomotivas (vendida para a General Eletric, em 1997); Batavo (para a Parmalat, em 1998); Mallory (vendida para a Moulinex, em 1998); Lojas Renner (para a inglesa J.C. Penney, em 1998); Chapecó (para o Grupo Macri, em 1999); parte da Aços Villares (para a Sidenor, em 2000); Portobello (para a Glencore, em 2001), etc. Também foram vendidas, entre outras, a Continental 2001, para a Bosch-Siemens, em 1994; a Refripar, para a Eletrolux, a Fogões Dako foi absorvida pela GE em 1996, além da aquisição da Walita pela Philips (Carta Capital, 24/12/97). 
O crescimento acumulado das transações no Brasil, na década de 1990, foi de 134\%, e o aumento da participação estrangeira nos negócios foi de 44\%. A KPMG dividiu os negócios durante a década em três períodos ${ }^{89}$ :

1. o primeiro período (1990-1993), foi marcado por negócios nos setores de química e petroquímica (22) e metalurgia e siderurgia (24).

2. no segundo período, correspondente ao início do Plano Real, os negócios incidiram nos setores: financeiro (107); eletroeletrônico (53) e autopeças (42). O ano de 1997 marcou o auge das transações realizadas no Brasil: 372 negócios com 54,84\% de participação estrangeira, e a venda da CVRD em maio de 1997 ao consórcio Valepar ${ }^{90}$.

3. Entre os anos de 1998 a 2000, os setores de telecomunicações (104 negócios) e tecnologia da informação (93) foram os que se destacaram, com a venda (leilão) do Sistema Telebrás e de bancos estaduais, como o Banespa.

Tabela III.8

Comparação anual de fusões e aquisições por setores no Brasil: 1992 - 2004

\begin{tabular}{|c|c|c|c|c|c|c|c|c|c|c|c|c|c|c|}
\hline SETORES & 1992 & 1993 & 1994 & 1995 & 1996 & 1997 & 1998 & 1999 & 2000 & 2001 & 2002 & 2003 & 2004 & $\begin{array}{l}\text { TOTA } \\
\mathrm{L}\end{array}$ \\
\hline Alimentos, bebidas e fumo & 12 & 28 & 21 & 24 & 38 & 49 & 36 & 25 & 36 & 32 & 29 & 22 & 25 & 377 \\
\hline Instituições financeiras & 4 & 8 & 15 & 20 & 31 & 36 & 28 & 16 & 18 & 17 & 20 & 16 & 10 & 239 \\
\hline Telecomunicações & 1 & 7 & 5 & 8 & 5 & 14 & 31 & 47 & 26 & 27 & 22 & 21 & 24 & 238 \\
\hline Tecnologia da Informação & & & 8 & 7 & 11 & 8 & 8 & 28 & 57 & 36 & 13 & 28 & 13 & 217 \\
\hline Metalurgia e siderurgia & 11 & 13 & 11 & 9 & 17 & 18 & 23 & 9 & 11 & 15 & 13 & 14 & 9 & 173 \\
\hline $\begin{array}{l}\text { Prod. químicos e } \\
\text { petroquímicos }\end{array}$ & 4 & 18 & 14 & 13 & 18 & 22 & 25 & 6 & 12 & 7 & 4 & 5 & 5 & 153 \\
\hline Companhias energéticas & 0 & 0 & 0 & 1 & 9 & 17 & 11 & 10 & 20 & 36 & 16 & 17 & 11 & 148 \\
\hline Petrolífero & 0 & 3 & 2 & 4 & 4 & 3 & 1 & 6 & 28 & 40 & 26 & 7 & 12 & 136 \\
\hline Publicidade e Editoras & & & & 2 & 5 & 9 & 19 & 17 & 23 & 19 & 12 & 12 & 15 & 133 \\
\hline Seguros & 1 & 1 & 8 & 9 & 16 & 24 & 15 & 9 & 6 & 7 & 5 & 10 & 10 & 121 \\
\hline Partes e peças automotivas & 1 & 1 & 4 & 11 & 11 & 16 & 20 & 13 & 6 & 6 & 4 & 1 & 3 & 97 \\
\hline Elétrico e eletrônicos & 2 & 7 & 5 & 14 & 15 & 19 & 9 & 5 & 5 & 2 & 4 & 1 & 3 & 91 \\
\hline Supermercados & & 3 & 2 & 0 & 2 & 9 & 13 & 24 & 10 & 8 & 4 & 5 & 2 & 82 \\
\hline Serviços p/ empresas & 0 & 2 & 2 & 1 & 8 & 6 & 13 & 8 & 5 & 9 & 7 & 9 & 2 & 72 \\
\hline Madeira e papel & 1 & 1 & 7 & 7 & 4 & 14 & 9 & 5 & 7 & 9 & 1 & 4 & 2 & 71 \\
\hline $\begin{array}{l}\text { Construção civil e produtos de } \\
\text { construção }\end{array}$ & 2 & 5 & 3 & 2 & 15 & 8 & 10 & 13 & 5 & 2 & 2 & 3 & 0 & 70 \\
\hline $\begin{array}{l}\text { Produtos químicos e } \\
\text { farmacêuticos }\end{array}$ & & & & 11 & 10 & 4 & 4 & 6 & 6 & 4 & 4 & 4 & 8 & 61 \\
\hline Produtos de engenharia & & & & 5 & 9 & 9 & 7 & 6 & 7 & 4 & 7 & 4 & 2 & 60 \\
\hline Transporte & 0 & 1 & 1 & 4 & 6 & 7 & 11 & 1 & 5 & 8 & 4 & 4 & 8 & 60 \\
\hline Têxteis & 2 & 4 & 7 & 8 & 4 & 8 & 8 & 6 & 0 & 0 & 0 & 6 & 2 & 55 \\
\hline Lojas de varejo & & & 1 & 2 & 7 & 8 & 6 & 7 & 5 & 6 & 2 & 2 & 1 & 47 \\
\hline
\end{tabular}

${ }^{89}$ KPMG Corporate Finance, 2001.

${ }^{90} \mathrm{O}$ consórcio era formado por CSN $(25,0 \%)$, Litel Part. S.A. (39,0\%), Eletron S.A. (17,0\%), Sweet River Investiments $(9,0 \%)$, BNDESPAR $(9,0 \%)$ e Investvale (1,0\%), conforme Biondi (1999). 


\begin{tabular}{|c|c|c|c|c|c|c|c|c|c|c|c|c|c|c|}
\hline Higiene & & 2 & 1 & 1 & 4 & 4 & 2 & 1 & 1 & 7 & 3 & 1 & 7 & 34 \\
\hline Montadoras de Veículos & 1 & 4 & 8 & 4 & 6 & 0 & 3 & 2 & 0 & 2 & 0 & 0 & 2 & 32 \\
\hline Embalagens & & & & 8 & 4 & 4 & 3 & 3 & 4 & 0 & 1 & 2 & 2 & 31 \\
\hline Indústrias extrativistas & 1 & 1 & 3 & 9 & 5 & 4 & 0 & 1 & 1 & 1 & 0 & 3 & 0 & 29 \\
\hline Serviços portuários & 1 & 0 & 2 & 2 & 4 & 2 & 2 & 2 & 1 & 4 & 1 & 2 & 1 & 24 \\
\hline Aviação & 0 & 0 & 3 & 5 & 2 & 2 & 1 & 1 & 1 & 2 & 1 & 2 & 1 & 21 \\
\hline Cimento & 0 & 1 & 0 & 0 & 5 & 6 & 1 & 6 & 3 & 3 & 3 & 1 & 4 & 21 \\
\hline Shopping Centers & & 1 & 1 & 0 & 2 & 4 & 2 & 1 & 2 & 2 & 4 & 1 & 0 & 20 \\
\hline Mineração & & & & 0 & 0 & 0 & 0 & 1 & 6 & 4 & 5 & 1 & 1 & 18 \\
\hline Hotéis & & & 4 & 2 & 4 & 0 & 2 & 1 & 1 & 1 & 0 & 1 & 1 & 17 \\
\hline Ferroviário & 0 & 0 & 0 & 1 & 7 & 0 & 0 & 2 & 2 & 0 & 1 & 0 & 0 & 13 \\
\hline Fertilizantes & & & & 0 & 0 & 0 & 4 & 1 & 5 & 2 & 0 & 1 & 0 & 13 \\
\hline Hospitais & & & 0 & 0 & 4 & 0 & 1 & 1 & 2 & 0 & 2 & 1 & 0 & 11 \\
\hline Design e projetos gráficos & & & 0 & 0 & 2 & 5 & 0 & 0 & 1 & 1 & 1 & 0 & 0 & 10 \\
\hline Outros & & & 0 & 16 & 36 & 32 & 22 & 15 & 26 & 16 & 6 & 19 & 20 & 208 \\
\hline TOTAL GERAL & 58 & 150 & 175 & 212 & 328 & 372 & 351 & 309 & 353 & 340 & 227 & 230 & 206 & 3311 \\
\hline
\end{tabular}

Fonte: KPMG Corporate Finance, Pesquisa Fusões \& Aquisições - Transações realizadas no Brasil, diversos exemplares. Elaboração do autor.

\section{III.2.5. O Setor de alimentos - líder em número de transações na década}

Na década de 1990, o setor de alimentos destacou-se na liderança no ranking de fusões e aquisições de empresas no Brasil. O setor de produtos alimentares reúne também os fabricantes de bebidas, e encontra-se relacionado ao setor de fumo, como aparece no levantamento da KPMG.

Entre os diversos negócios que movimentaram o setor, mencionamos a aquisição, em 1993, da CICA S.A., empresa italiana do Grupo Círio ${ }^{91}$, pela Gessy Lever, por US\$ 250 milhões. A Frutesp, antiga cooperativa de produtores de laranja do estado de São Paulo, foi adquirida pelo Grupo Dreyfuss, por US\$ 170 milhões. O Grupo Dreyfuss compete com a Cargill, a ADM e a Continental Grain, e é o $3^{\circ}$ maior processador mundial de suco de laranja ${ }^{92}$.

O total de transações no setor de alimentos, em 1993, assomou US\$ 700 milhões, com negócios envolvendo, como compradoras, as empresas: Parmalat, Nestlé, Danone e Bunge y Born. A Parmalat destacou-se adquirindo laticínios a partir de 1990, e em abril de 1993, realizou importante aquisição: comprou as fábricas Lu Petybon e Duchen, de propriedade da

${ }^{91}$ O Grupo Círio fundiu-se com o Grupo Del Monte, fortalecendo o segmento de alimentos em conserva, com faturamento de 900 milhões de euros. A empresa tem importante participação na Europa, na Ásia, África e Brasil (http://www.cirio.it/, acessado em 10/10/2004).

${ }^{92}$ Lodi, 1999, p. 32. 
General Biscuits. Com todas as suas aquisições, a Parmalat aumentou seu faturamento, de US\$ 39 milhões, em 1989, para aproximadamente US\$ 750 milhões em 1994, cerca de 30\% do faturamento mundial da empresa (Vegro e Sato, 1995, p. 15-16).

A Nabisco adquiriu as empresas: Avaré, Gumz e Pilar. A Danone adquiriu a Aymoré e a Campineira. A Quaker Oats adquiriu a Adria e a Pilsbury ficou com a Frescarini (Rodrigues, 1999. p. 15).

A primeira inauguração de uma fábrica da Parmalat fora da Itália ocorreu no Brasil, em 1977, entretanto, a empresa já atuava no país, em uma joint-venture com a Mococa, desde 1973. Nos anos 1990, a Parmalat adquiriu no Brasil mais de 30 empresas, uma boa parte dessas aquisições era formada de pequenos laticínios (11, até 1994), de estrutura familiar, e com atuação regional. À época, os investimentos superaram US\$ 500 milhões. Ao final da década, a expansão por aquisições já havia terminado, mas a empresa contava em seu portfolio com marcas importantes, tais como: Etti, Batavo, Lacesa, Leite Bethânia, Mimo e Santal (Champi Jr. e Barbosa, 2004, p. 4), além de Bols, Cilpe e King Meat (Rodrigues, p. 14). Em 1998, a empresa adquiriu do Grupo Fenícia a Neugebauer, antigo produtor de chocolates localizado no Rio Grande do Sul, por R\$ 8,36 milhões ${ }^{93}$. Em 2002, a Parmalat vendeu a Neugebauer para a Florestal Alimentos.

Entre 1997 e 1999, as empresas multinacionais do setor de sementes de milho, aumentaram a sua participação de $50 \%$ para $90 \%$ do mercado nacional. A norte-americana Monsanto detinha 63\% de participação ao final de 1997. Esta empresa adquiriu a Agroceres e a divisão latino-americana da Cargill, respectivamente líder e vice-líder no mercado brasileiro. Além dessas empresas, a Monsanto adquiriu também a FT Pesquisas e Sementes de Soja, e a Braskalb, associada a DeKalb Genetics (empresa norte americana adquirida pela Monsanto em 1998).

\footnotetext{
${ }^{93}$ Valores conforme Gazeta Mercantil, 31/12/1998.
} 
Tabela III.9

\section{Participações no mercado de sementes}

\begin{tabular}{|l|l|l|l|}
\hline \multicolumn{2}{|c|}{ Até 1997 } & \multicolumn{2}{c|}{ Depois de 1997 } \\
\hline \multicolumn{5}{|c|}{ Milho } \\
\hline Agroceres & 26 & Monsanto & 60 \\
\hline Cargill & 26 & Pioneer/DuPont & 14 \\
\hline Pioneer & 14 & Novartis & 11 \\
\hline Novartis & 11 & Unimilho & 4 \\
\hline Braskalb & 8 & Dow/Mycogen & 5 \\
\hline Dinamilho/Carol & 3 & Zeneca & 3 \\
\hline Agroeste (SC) & 1 & AgrEvo & 2 \\
\hline Outros & 12 & Outros & 1 \\
\hline \multicolumn{5}{|l|}{ Soja } \\
\hline Sistema Embrapa & 70 & Sistema Embrapa & 65 \\
\hline FT Sementes & 12 & Monsanto/FT & 18 \\
\hline Coodetec (PR) & 10 & Coodetec (PR) & 10 \\
\hline IAC (SP) & 2 & IAC (SP) & 2 \\
\hline Dois Marcos (RS) & 1 & Pioneer/Dupont & 1 \\
\hline Outros & 5 & Outros & 4 \\
\hline
\end{tabular}

Fonte: Embrapa Sementes Básicas, apud Gazeta Mercantil (16/06/1999).

O grupo AgrEvo adquiriu, nesses três anos, a Granja 4 Irmãos, do Grupo Josapar, Sementes Ribeiral, Mitla Pesquisa Agrícola e Sementes Fatura. O Grupo Dow AgroSciencies comprou a Sementes Colorado, a Dinamilho/Carol, a Sementes Hatã e a FT Sementes de Milhos. A Pioneer/Dupont adquiriu a Agropecuária Dois Marcos ${ }^{94}$.

A Ceval, do ramo de alimentos pertencente ao grupo Hering constituiu, em 1991, uma esmagadora de soja em Rondonópolis (MT) e uma unidade em Barreiras (BA); um consórcio com o Grupo Itamarati, em 1992, para instalar uma unidade em Lisboa; adquiriu o Grupo Agroeliane (Criciúma), com dois abatedouros de aves, um de suínos, dez granjas, duas fábricas de ração, etc.; nesse ano, o Grupo ainda adquiriu a empresa Guiopeba S.A. (Argentina), com duas unidades de industrialização, por US\$ 30 milhões. Entretanto, apesar de seus investimentos, a Ceval foi incorporada pelo Grupo Bunge ${ }^{95}$.

O grupo Bunge atua no país desde o início do século XX, quando adquiriu a Moinho Santista (que produzia as farinhas Sol, Santista e Paulista). Após adquirir a Cavalcanti \& Cia, em 1923, alterou a sua razão social para Sanbra (Sociedade Algodoeira do Nordeste

\footnotetext{
${ }^{94}$ Gazeta Mercantil, 16/06/1999.

95 Espíndola, 1999, p. 48.
} 
Brasileiro), e lançou no mercado o primeiro óleo vegetal (marca Salada), ao qual reputa-se a substituição na cozinha dos produtos banha de porco e azeite importado. Em 1956, lançou misturas preparadas para bolos e salgados e a Pré-Mescla, de produtos voltados para panificadoras. Em 2004, o grupo controla as empresas: Seara, Ceval (ramo de alimentação, soja e carnes), Santista Alimentos (que absorveu Moinho Santista e a Sanbra), a Covebrás e o Moinho Ideal; em massas e pães, a Pullman Alimentos, e é proprietário de marcas importantes como margarina Delícia, Primor e Mila, entre outras; em fertilizantes, controla a Manah, Serrana, Fertimport e IAP ${ }^{96}$.

A reestruturação da Bunge - cujo objetivo era priorizar os negócios na área de grãos (soja) e fertilizantes, desfazendo-se do setor alimentos (no Brasil, a Ceval -setor de carnes; na Argentina a Molinos Rio de La Plata, e na Venezuela, a Gramoven) - iniciou-se pela Austrália, em 1998, quando vendeu os seus ativos correlacionados a área de farinhas e de massas, entre outros, por US\$ 276 milhões, para a Goodman Fielder ${ }^{97}$. Com a venda da Molinos Rio de La Plata, o Grupo deixa a marca Bunge y Born, e passa a denominar-se Grupo Bunge.

O Grupo Bunge, organizando seus negócios de fertilizantes, após adquirir a Fertisul, em 1996, e a IAP, em 1997, incorporou ambas na Serrana, em julho de 1998. A empresa, detentora de ações da AST-Alpargatas Santista Têxtil, vendeu as ações para a Bunge International, em uma estratégia do grupo de se desfazer de negócios dissociados do setor de fertilizantes ${ }^{98}$. No mesmo setor, a Bunge comprou a Manah, por R\$ 143,8 milhões, e passou a controlar $25 \%$ do mercado de fertilizantes, distante da Cargill, $2^{\mathrm{a}}$ colocada no ranking, com cerca de $10 \%$ de participação, em um setor onde cresce a participação estrangeira: a Norsk Hydro (Noruega), a maior indústria de fertilizantes mundial, assumiu a Adubos Trevo (RS) ${ }^{99}$.

Finalmente, a Bunge formou uma joint venture com a DuPont, denominada Solae L.L.C. para a produção e distribuição, no início, de proteínas de soja e lecitina, e posteriormente de outros ingredientes extraídos do milho e da soja para fornecer à indústria de alimentos. A participação da DuPont na nova empresa é de $72 \%$, cabendo à Bunge, $28 \%$. A idéia é produzir uma variedade completa de produtos relacionados à soja ${ }^{100}$.

\footnotetext{
${ }^{96}$ Informações colhidas em visita à unidade de Rondonópolis (MT), em 23/10/2004, e Forbes Brasil, 16/07/2004 .

${ }^{97}$ Gazeta Mercantil, 23/11/1998.

${ }^{98}$ Gazeta Mercantil, 21/12/1998.

${ }^{99}$ Gazeta Mercantil, 14/04/2000.

${ }^{100}$ Gazeta Mercantil, 07/01/2003.
} 
A Perdigão, cujo crescimento também ocorreu através de fusões e diversificação nos anos 1970-80, após um período de crescente endividamento e acúmulo de uma série de prejuízos, terminou por vender empresas como a Perdigão Amazônia, fábrica de enlatados, frigorífico e a Refinadora de Óleo (Maraú-RS). O que sobrou da Perdigão foi adquirido por uma associação de fundos de pensão (Previ, Sistel, Petros, Fapes, Telos, etc.), que contou com a participação, inclusive, da Bunge ${ }^{101}$.

A Sadia, em um processo de diversificação e reestruturação, implantou unidades de abate e processamento de carne avícola, moinhos de trigo, frigoríficos (inclusive de carne bovina), e entrou no esmagamento de oleaginosas. Adquiriu, a partir de 1992, a Cia. Brasileira de Alimentos S.A.-COMABRA (Ponta Grossa/PR), e no mesmo ano, duas empresas de industrialização de carne de boi. Em 1993 funde-se com o Grupo J. Macedo Alimentos, do mercado de massas alimentícias (surge a Lapa Alimentos S.A.) ${ }^{102}$.

A Sadia terminou por vender sua unidade de soja em Rondonópolis para a Archer Daniels Midland - ADM, uma das grandes esmagadoras de soja do mundo, em 1997, por US\$ 165 milhões, além de desfazer-se, também, de abatedouros, uma rede de supermercados regionais no sul e um hotel em Concordia $(\mathrm{SC})^{103}$.

\section{III.2.5.1 O setor sucroalcooleiro}

Na tabela III.10 há dados do ramo sucroalcooleiro, contabilizados no setor de Alimentos, Bebidas e Fumo. Houve um crescimento das transações no ramo, no período de 1998 até o início de 2003, e este tem se destacado, por causa do dinamismo verificado no setor de alimentos e a importância cada vez maior do agronegócio no país, em consequiência do aumento das exportações de produtos primários.

Conforme pesquisa da consultoria KPMG, em 2002 a liderança das fusões e aquisições coube ao setor de Alimentos, Bebidas e Fumo, onde predominou isoladamente o ramo sucroalcooleiro, com a efetivação de 8 negócios. Em 2000, foram 7 aquisições nesse ramo, e em 2001 ocorreram 10 transações. A partir de 1998, o Grupo Cosan adquiriu 8 usinas,

\footnotetext{
${ }^{101}$ Vegro e Sato, 1995, p. 17.

102 Vegro e Sato, 1995, p. 17.

${ }^{103}$ Lodi, 1999, p. 63.
} 
o Grupo João Pessoa 6 usinas e a Coinbra/Dreyfuss, 2 usinas. No período 1998 - 2003 (1 trimestre) ocorreram 31 transações assim divididas: 26 aquisições, 03 fusões e 02 arrendamentos.

Vários fatores estariam causando o aumento das fusões e aquisições no setor, cujo desempenho nos anos anteriores a 1998 foi bem modesto: altos preços do açúcar no mercado externo, o dólar valorizado frente ao Real, aumento da concorrência entre os compradores, e a estratégia de ganhar escala ${ }^{104}$.

Tabela III.10:

TRANSAÇÕES - SETOR SUCROALCOOLEIRO: 1998 - $1^{\circ}$ TRIMESTRE/2003

\begin{tabular}{|c|c|c|c|c|}
\hline $\mathrm{ANO}$ & EMPRESA & ESTADO & COMPRADOR & TIPO \\
\hline 1998 & $\mathrm{Ci}^{\mathrm{a}}$ Açucareira São Geraldo & SP & Usina Santa Elisa S.A. & Fusão \\
\hline 1998 & Usina Diamante & SP & Cosan & Aquisição \\
\hline 1998 & Usina Adelaide & SP & Usina da Barra & Aquisição \\
\hline 1999 & Usina Sanagro & SP & Grupo José Pessoa & Fusão \\
\hline 1999 & Usina Iracema & $\mathrm{SP}$ & Usina São Martinho & Fusão \\
\hline 2000 & Usina Rafard & SP & Grupo Cosan & Aquisição \\
\hline 2000 & Usina Amalia/Santa Rosa & SP & Usina da Pedra & Aquisição \\
\hline 2000 & Usina Benaalcool & SP & Grupo José Pessoa & Aquisição \\
\hline 2000 & Usina Delta & MG & Grupo Carlos Lyra & Aquisição \\
\hline 2000 & Usina Cresciumal & SP & Coinbra/Dreyfuss & Aquisição \\
\hline 2000 & Destileria Vale do Rio Turvo & SP & Silveira Barros/Jorge Toledo & Aquisição \\
\hline 2000 & Ipaussu & $\mathrm{SP}$ & Union des Sucreries Agricoles & Aquisição \\
\hline 2001 & Alcovale Destilaria & MS & Unialco S/A Açúcar e Álcool & Aquisição \\
\hline 2001 & Refinadora Catarinense & $\mathrm{SC}$ & Glencore & Aquisição \\
\hline 2001 & Açucareira da Serra & SP & Grupo Cosan & Aquisição \\
\hline 2001 & Usina Alcomira & SP & Grupo Márcio José Pavan & Aquisição \\
\hline 2001 & Univalem/Guanabara (50\%) & SP & FBA & Aquisição \\
\hline 2001 & Destileria Água Limpa & $\mathrm{SP}$ & Grupo Petribu & Aquisição \\
\hline 2001 & Açúcar Guarani & $\mathrm{SP}$ & Béghin-Say & Aquisição \\
\hline 2001 & Usina São José & SP & Grupo Antonio Farias & Aquisição \\
\hline 2001 & Usina Luciânia & MG & Coinbra-Dreyfuss & Aquisição \\
\hline 2001 & Usina Santo Antonio & SP & FBA & Arrendamento \\
\hline 2002 & Usina Bela Vista & SP & Usina Bazan & Aquisição \\
\hline 2002 & Guanabara & SP & Grupo Cosan & Aquisição \\
\hline 2002 & Usina Santa Cruz & $\mathrm{RJ}$ & Grupo José Pessoa & Aquisição \\
\hline 2002 & Usina Maluf & SP & Dulcini & Aquisição \\
\hline 2002 & Usina Junqueira & $\mathrm{SP}$ & Grupo Cosan & Arrendamento \\
\hline 2002 & Usina Gantus & $\mathrm{SP}$ & Grupo Toledo & Aquisição \\
\hline 2002 & Usina da Barra & SP & Grupo Cosan & Aquisição \\
\hline 2002 & Usina Alcoazul & $\mathrm{SP}$ & Grupo José Pessoa & Aquisição \\
\hline 2003 & Usina Quissaman & $\mathrm{SP}$ & Grupo José Pessoa & Aquisição \\
\hline
\end{tabular}

Fonte: KPMG Corporate Finance (GZM, 26/03/03)

${ }^{104}$ Gazeta Mercantil, 26/03/2003. 


\section{III.3. O processo de privatização no Brasil}

Assim como os processos realizados nos demais países latino-americanos, a privatização no Brasil deu-se em função de um conjunto de medidas de governo estabelecidas na década passada, uma fórmula que envolvia a perspectiva neoliberal em um ambiente de crise econômica, endividamento externo, dificuldades de investimentos através do Estado. Divulgava-se, à época, que a crise econômica relacionava-se ao tamanho do Estado, "inchado" em decorrência de excessiva participação na economia, em uma análise que propunha a sua redução através da privatização e a redução de seus gastos. A privatização tornou-se o mote de uma propaganda que disseminava e insistia na idéia de que as empresas estatais eram ineficientes, em função do monopólio estatal, da falta de concorrência e da falência generalizada do Estado. Essa verdadeira propaganda divulgava que a participação do Estado na economia era excessiva, apenas isso, mas omitia o fato de que nem todas as empresas estatais eram ineficientes. Desconsiderava-se o fato de que algumas eram estratégicas e muito cobiçadas pelo grande capital, fosse nacional ou estrangeiro. $\mathrm{O}$ fato de que as empresas estatais eram o patrimônio do país também não contava, assim como era irrelevante se a população discordava do processo ou da venda de empresas específicas ${ }^{105}$. E havia discordâncias, fossem de sindicatos, associações de funcionários ou da população em geral. Os primeiros, preocupados com a possibilidade de perderem seus empregos, e os segundos, forçosamente desinformados das implicações do processo.

Entretanto, o aspecto fundamental a ser ressaltado, refere-se à utilização dos recursos do país na recuperação de um projeto de desenvolvimento, o que terminou por não ocorrer. Sob o regime neoliberal deixou-se de utilizar a capacidade ociosa da indústria do país e de alavancar investimentos para o desenvolvimento e o crescimento econômico, conforme proposta formulada por Ignácio Rangel $(1983,1985,1987)$ de concessão de serviços públicos.

\footnotetext{
${ }^{105}$ Quando se fala em "propaganda" ou "divulgação", refere-se ao fato de que, pelo apoio da mídia em geral, foi pequena a resistência ao andamento de propostas efetivamente não esclarecidas nas campanhas eleitorais. Os jornais da época, lidos agora, reverberam como campanha publicitária, com poucos comentários críticos e poucas vozes dissonantes, pela falta de espaço disponibilizado e pelos interesses envolvidos. Assim é que, "Privatizar se tornou a palavra de ordem. Todos os meios foram utilizados para convencer a opinião pública dos benefícios e do caráter bem-fundado da privatização. Naqueles primeiros anos, o governo - amplamente secundado pela mídia, insistiu em duas idéias básicas: as empresas estatais eram obsoletas (...) e o Estado brasileiro estava falido..." (Lesbaupin e Mineiro, 2002, p. 29).
} 


\section{III.3.1 A privatização de setores estratégicos}

No período 1991-1999, as privatizações realizadas no Brasil, tanto em âmbito federal como estadual, totalizaram US\$ 71,2 bilhões. Tais privatizações ocorreram em setores considerados estratégicos da economia nacional, com o setor de telecomunicações representando $37 \%$ do total desses negócios; energia elétrica, 33\%; siderurgia, 9\%; mineração, $8 \%$ e petroquímico, $4 \%$ (Lacerda, 2000).

Os setores de transportes (ferroviário, rodoviário, e portos), bem como os setores siderúrgicos, de energia elétrica e comunicações, são exemplos das diferentes condições em que se encontravam as empresas públicas a eles relacionadas. Essas empresas, definidas como estratégicas, são importantes na realização de projetos que garantem o desenvolvimento econômico e social do país, porém, do final do regime militar e durante a transição para o regime civil, ou transição da década de 1980 para a década de 1990, os investimentos nessas empresas e serviços sob responsabilidade do Estado diminuíram. A causa da diminuição dos investimentos estava na crise econômica mundial, associada ao período de depressão do $4^{\circ}$ Kondratieff (a partir de 1973), concomitante à depressão do ciclo interno (iniciada em 1980), ou seja, uma crise internacional e uma crise interna, aprofundando a recessão e dificultando o crescimento econômico. A proposta de Rangel (1983, 1985), de superação da crise, passava pela transferência da "concessão de serviços públicos concedidos a empresas públicas" para a “concessão de serviços públicos concedidos a empresas privadas”. A empresa concessionária teria condições de levantar os recursos para realizar os investimentos necessários ao serviço, com o objetivo de buscar a sua melhoria, mas, principalmente, estimular a economia do país. Rangel entendia que as empresas e os serviços a serem concedidos deveriam ser aqueles que estivessem "estrangulados", carentes de investimentos, através da construção de obras de infra-estrutura, como rodovias, ferrovias, portos, construção naval, saneamento básico, metrôs, entre outros. O importante seria carrear recursos para reativar a economia, através da utilização de empresas que estivessem funcionando com capacidade ociosa, ou superinvestidas, como ocorria em setores da indústria nacional e mesmo em empresas estatais, como nos setores de siderurgia, construção civil, etc. 


\section{III.3.1.1 A privatização do setor de transportes e portuário}

\section{As Ferrovias}

Até 1993, a malha ferroviária brasileira era composta sobretudo pela RFFSA, responsável pela cobertura de $77 \%$ da extensão total da malha, pelo sistema paulista da FEPASA e pelo sistema CVRD/EFVM, responsável pela maior produção (TKU) nacional (ver tabela III.11, abaixo).

Tabela III.11

Malha Ferroviária Brasileira - 1993

\begin{tabular}{|c|c|c|c|c|c|c|}
\hline & RFFSA & FEPASA & $\begin{array}{l}\text { CVRD } \\
\text { EFMV }\end{array}$ & $\begin{array}{c}\text { CVRD } \\
\text { EFC }\end{array}$ & Outras & Total \\
\hline \multirow[t]{2}{*}{ Extensão $(1000 \mathrm{Km})$} & 22,1 & 4,3 & 0,9 & 1,1 & 0,4 & 28,8 \\
\hline & $77 \%$ & $15 \%$ & $3 \%$ & $4 \%$ & $1 \%$ & $100 \%$ \\
\hline \multirow[t]{2}{*}{ Produção (bilhões t,Km útil) } & 39,8 & 7,0 & 44,8 & 32,8 & 0,8 & 125,2 \\
\hline & $32 \%$ & $5 \%$ & $36 \%$ & $26 \%$ & $1 \%$ & $100 \%$ \\
\hline t,Km útil (milhões) & 1,8 & 1,6 & 49,8 & 29,8 & 2,0 & 4,3 \\
\hline
\end{tabular}

Fonte: BNDES (nov. 2000, p. 3)

Conforme Biondi (1999), os concessionários ficaram assim estabelecidos de acordo com os dados da tabela III.12, a seguir. Biondi ressalta que para a Rede Ferroviária Federal o valor da privatização foi apenas aparente:

Os preços divulgados para as ferrovias privatizadas são fictícios: houve apenas uma entrada de $10 \%$ a $15 \%$ (só para a malha Sudeste o percentual chegou a 30\%); o valor restante será pago em 30 anos, sem correção para saldo devedor, isto é, com atualizações apenas das prestações trimestrais (Biondi, 1999, p. 39)

Conforme BNDES (nov. 2000), as concessões foram estabelecidas pelo período de 30 anos, podendo ainda ser renovadas por igual período. Inicialmente não foi permitido o controle de mais de $20 \%$ de participação da concessão por investidor. 
Tabela III.12

Estrutura do Capital após Leilão de Arrendamento / Concessão

\begin{tabular}{|c|c|c|c|}
\hline Rede Ferroviária & $\begin{array}{l}\text { Consórcio ou } \\
\text { Controle }\end{array}$ & Concessionários & Participação \\
\hline Malha Oeste & $\begin{array}{l}\text { Grupo } \\
\text { controlador }\end{array}$ & $\begin{array}{l}\text { Noel Group, Inc. } \\
\text { Brazil Rail Partners, Inc. } \\
\text { Western Rail Investrs, LLC }\end{array}$ & $\begin{array}{l}20 \% \\
20 \% \\
20 \%\end{array}$ \\
\hline & Outros & $\begin{array}{l}\text { Bankamerica Intern. Invest. Corp. } \\
\text { DK Partners } \\
\text { Chemical Latin America Equity Assoc. }\end{array}$ & $\begin{array}{r}18 \% \\
2 \% \\
20 \% \\
\end{array}$ \\
\hline $\begin{array}{c}\text { Malha Leste } \\
\text { (valor US\$ } 320 \\
\text { milhões) }\end{array}$ & $\begin{array}{l}\text { Consórcio } \\
\text { Tucumã }\end{array}$ & $\begin{array}{l}\text { Mineração Tucumã } \\
\text { Interférrea S. A Serv. Intermodais } \\
\text { Siderúrgica Nacional } \\
\text { Tupinambarana S. A. } \\
\text { Railtex Int. Holdings, Inc. } \\
\text { Vabra S.A. } \\
\text { Ralph Partners I } \\
\text { Judori Adm. Empr. e Part. Ltda. } \\
\end{array}$ & $\begin{array}{l}12,5 \% \\
12,5 \% \\
12,5 \% \\
12,5 \% \\
12,5 \% \\
12,5 \% \\
12,5 \% \\
12,5 \% \\
\end{array}$ \\
\hline $\begin{array}{l}\text { Malha Sudeste } \\
\text { (valor US\$ } 870 \\
\text { milhões) }\end{array}$ & $\begin{array}{l}\text { Consórcio } \\
\text { MRS } \\
\text { Logística }\end{array}$ & $\begin{array}{l}\text { Siderúrgica Nacional } \\
\text { MBR - Minerações Brasileiras Reunidas SA } \\
\text { Ferteco Mineração S.A. } \\
\text { Usiminas - Usinas Siderúrgicas de MG } \\
\text { Consigua - Cia Siderúrgica da Guanabara } \\
\text { Celato Integração Mutimodal S. A. } \\
\text { Ultrafértil } \\
\text { ABS - Empreend. Imob. Part. Serv. S.A. }\end{array}$ & $\begin{array}{r}20,0 \% \\
20,0 \% \\
18,8 \% \\
20,0 \% \\
5,3 \% \\
4,3 \% \\
8,9 \% \\
4,7 \% \\
\end{array}$ \\
\hline Tereza Cristina & $\begin{array}{l}\text { Associação dos } \\
\text { Participantes }\end{array}$ & $\begin{array}{l}\text { Banco Interfinance } \\
\text { Gemon Geral de Engenharia e Montagens S.A. } \\
\text { Santa Lúcia Agroindústria e Comércio Ltda. }\end{array}$ & $\begin{array}{l}33,3 \% \\
33,3 \% \\
33,3 \%\end{array}$ \\
\hline $\begin{array}{c}\text { Malha Sul } \\
\text { (valor US\$ } 210 \\
\text { milhões) }\end{array}$ & $\begin{array}{l}\text { Consórcio } \\
\text { Sul Atlântico }\end{array}$ & $\begin{array}{l}\text { Ralph Partner's Inc. } \\
\text { Varbra S.A. } \\
\text { Railtex } \\
\text { Interférrea } \\
\text { Brasil Private Equily } \\
\text { Brazilian Equity Investiments III Ltda. }\end{array}$ & $\begin{array}{r}17,5 \% \\
17,5 \% \\
15,0 \% \\
17,5 \% \\
11,3 \% \\
3,0 \%\end{array}$ \\
\hline Malha Nordeste & $\begin{array}{l}\text { Consórcio } \\
\text { Manor }\end{array}$ & $\begin{array}{l}\text { Taquari Participações } \\
\text { Companhia Siderúrgica Nacional } \\
\text { Companhia Vale do Rio Doce } \\
\text { ABS Empreendimentos, Part. e Servições S.A. }\end{array}$ & $\begin{array}{l}40,0 \% \\
20,0 \% \\
20,0 \% \\
20,0 \%\end{array}$ \\
\hline Malha Paulista & $\begin{array}{l}\text { Consórcio } \\
\text { Ferrovias }\end{array}$ & $\begin{array}{l}\text { Ferropasa - Ferronorte Participações } \\
\text { Vale do Rio Doce } \\
\text { Shearer Empreendimentos e Participações S.A } \\
\text { Fundos de Pensão (Previ/Funcef) } \\
\text { Chave Latin American Equity Associates } \\
\text { Outros }\end{array}$ & $\begin{array}{r}36,0 \% \\
17,0 \% \\
14,0 \% \\
12,0 \% \\
4,0 \% \\
17,0 \%\end{array}$ \\
\hline
\end{tabular}

Fonte: Biondi (1999, p. 39, 47-48)

As concessões da Estrada de Ferro Carrajás (EFC) e da Estrada de Ferro VitóriaMinas (EFVM) foram automaticamente transferidas para os novos proprietários da CVRD quando esta foi privatizada. 
A FEPASA foi absorvida pela RFFSA durante a negociação da dívida do Estado de São Paulo com a União e, posteriormente, arrendada como lote único (o sétimo lote da RFFSA), para a Ferrovias Bandeirantes S.A. (Ferroban), colocando em questão o acesso ao Porto de Santos na disputa de interesses entre as concessionárias. A MRS Logística detém o monopólio de acesso ao Porto de Santos, submetendo a Ferronorte a seus critérios, custos e dispêndios de tempo no desmembramento de trens no Porto ${ }^{106}$.

A RFFSA, por sua vez, foi dividida em seis lotes -- Sul, Sudeste, Centro-Leste, Oeste, Nordeste e o trecho isolado Tereza Cristina e transferida no leilão de desestatização, aos concessionários privados América Latina Logística (ALL), MRS Logística S.A., Ferrovia Centro-Atlântica S.A. (FCA), Ferrovia Novoeste S.A., Companhia Ferroviária do Nordeste (CFN), Ferrovia Tereza Cristina S.A.

A Ferroban é a concessionária mais estratégica para a malha ferroviária federal, com ligação com a FCA, MRS, ALL, Novoeste e Ferronorte. Em janeiro de 1999, a Ferroban assumiu o controle da malha paulista (antiga FEPASA), com $2.916 \mathrm{Km}$ de ferrovias que interligam o Porto de Santos com o interior de São Paulo e os estados de Mato Grosso e Mato Grosso do Sul. Em 2001, a empresa em processo de reestruturação acionária transferiu os trechos Botucatu-Presidente Epitácio e Iperó-Pinhalzinho para a ALL e o trecho Araguarí-Boa Vista para a FCA. Em 2002, a Ferroban, a Ferronorte e a Novoeste foram integradas à nova empresa a holding Brasil Ferrovias S.A. (Ferropasa) formando dois corredores de exportação: Corumbá (MS)-Santos e Alto Araguaia-MT/Santos. No ano de 2004, a Ferroban repassou para a MRS o trecho Jundiaí-Campinas. Os acionistas majoritários são os controladores da Ferronorte, Ferropasa (Previ, Funcef, Laif, Chase, Constran, etc.) CVRD e Capmelissa Participações.

A estrutura societária da FCA era a CVRD (através da Mineração Tucumã), maior acionista do grupo concessionário, a Valia, a CSN, a KRJ Participações, Carmo Participações e outros minoritários. Em 2000 a CVRD assumiu a empresa, incorporando dívidas.

\footnotetext{
${ }^{106}$ O sistema utilizado pela MRS aumenta seu controle sobre a movimentação de carga na porção mais dinâmica do Porto de Santos, além de repassar os custos do sistema aos demais concessionários e gastar 110 horas no processo de descarga e recarga dos trens, quando poderia utilizar apenas 33 horas se alterasse o sistema (BNDES, nov. 2000)
} 
A FTC é controlada por Germon, Santa-Lucia Agro-Indústria e Comércio e Interfinance Participações. A empresa compõe o sistema de abastecimento de carvão para a Eletrosul.

A holding ALL é composta por Fundos de Investimentos, controlados pelo GP Investimentos, Judori, Railtex Global Investiments e outros. A empresa integra dois sistemas: ALL Brasil e ALL Argentina, ligando São Paulo a Buenos Aires em operação multimodal. Na Argentina, a empresa detém dois ramais ferroviários: a Buenos Aires Al Pacífico (Buenos Aires-Mendonza) e a Mesopotamico (Buenos Aires-Uruguaiana).

A CFN é controlada pelo grupo Vicunha e recebeu do governo R 200 milhões de investimentos para criação da Ferrovia Transnordestina, para interligar o São Francisco e a região produtora de grãos do sertão baiano, porém não está cumprindo as metas estabelecidas pelo governo no cronograma de investimento.

As empresas ferroviárias estão associadas direta ou indiretamente aos principais grupos empresariais do país (CVRD, CSN, Vicunha entre outros) cujas estratégias de transporte estão subordinadas às diretrizes logísticas dessas empresas. A redução de pessoal no período 1996-1999 foi de aproximadamente 20 mil funcionários - a ALL atingiu 70\% do quadro funcional e a FCA eliminou trabalhadores e ampliou o número de acidentes.

\section{As rodovias}

O processo de privatização das rodovias ocorreu com o estabelecimento das concessões de serviços públicos ao setor privado, conforme a tabela III.13. 
Tabela III.13

\begin{tabular}{|c|c|c|c|c|}
\hline Rodovia ou região & Concessionária & Ano & $\begin{array}{l}\text { Prazo } \\
\text { (anos) }\end{array}$ & $\begin{array}{c}\text { Extensão } \\
(\mathrm{Km})\end{array}$ \\
\hline \multicolumn{5}{|l|}{ Rodovias Federais } \\
\hline Ponte Rio-Niterói & $\begin{array}{l}\text { Ponte S.A. (Camargo Corrêa, Andrade Gutierrez, Serveng, } \\
\text { Civilisan e Odebrecht) }\end{array}$ & 1994 & 20 & 13 \\
\hline $\begin{array}{l}\text { Rodovia Rio-Juiz de Fora (BR } \\
040 \text { ) }\end{array}$ & $\begin{array}{l}\text { Concer S. A. (Triunfo Construcap, CCI Concessões e } \\
\text { Metropolitana S.A.) }\end{array}$ & 1995 & 25 & 180 \\
\hline $\begin{array}{l}\text { Rodovia Rio-São Paulo (BR } \\
\text { 116) }\end{array}$ & $\begin{array}{l}\text { Novadutra (Carmargo Corrêa, Andrade Gutierrez,SErveng- } \\
\text { Civilizan e Odebrecht) }\end{array}$ & 1995 & 25 & 407 \\
\hline $\begin{array}{l}\text { Rodovia Rio-Teresópolis (BR } \\
116)\end{array}$ & $\begin{array}{l}\text { CRT (OAS, Carioca, Chistian Nielsen, Strata e Queiroz } \\
\text { Galvão) }\end{array}$ & 1995 & 25 & 144 \\
\hline $\begin{array}{l}\text { Rodovia Osório-Porto Alegre } \\
\text { (BR 290) }\end{array}$ & Concepa (Triunfo Participações e SBS Engenharia) & 1997 & 20 & 112 \\
\hline Ecosul (BR 392 e 116) & $\begin{array}{l}\text { Ecosul S.A. (Primav, Construtora Triunfo, Ivaí, Engenharia } \\
\text { e SBS Engenharia) }\end{array}$ & 2001 & & 552 \\
\hline \multicolumn{5}{|c|}{ Rodovias de São Paulo (100\% rodovias estaduais) } \\
\hline Região de Campinas & Autoban & 1998 & & 313 \\
\hline Região de Bebedouro & Tebe & 1998 & & 156 \\
\hline Região de Riveirão Preto & Via Norte & 1998 & & 235 \\
\hline Região de Itapira & Intervias & 2000 & & 364 \\
\hline Região de Jaú & Centrovias & 1998 & & 219 \\
\hline Região de Araraquara & Triângulo do Sol & 1998 & & 440 \\
\hline Região de Batatais & Autovias & 1998 & & 317 \\
\hline Região de S. J. B. Vista & Renovias & 1998 & & 290 \\
\hline Região de Sorocaba & Viaoeste & 1998 & & 174 \\
\hline Região deItu & Rodovia das Colinas & 2000 & & 299 \\
\hline Região de Itapetininga & SPVias & 2000 & & 516 \\
\hline Região Baixada Santista & Ecovias & 1998 & & 194 \\
\hline \multicolumn{5}{|c|}{ Rodovias do Rio Grande do Sul (70\% rodovias federais) } \\
\hline Pólo Metropolitano & Metrovias & $1998 *$ & 15 & 805 \\
\hline Pólo Caxias do Sul & Convias & $1998 *$ & 15 & 174 \\
\hline Pólo Vacaria & Rodosul & $1998 *$ & 15 & 133 \\
\hline Pólo Carazinho & Coviplan & $1998 *$ & 15 & 250 \\
\hline Pólo Santa Maria & Santa Maria (Rodovias) & $1998 *$ & 15 & 256 \\
\hline Pólo Santa Cruz & Santa Cruz & $1998 *$ & 15 & 197 \\
\hline Pólo Sulvias & Sul Vias & $1998 *$ & 15 & 319 \\
\hline Pólo Brita & Brita & $1998 *$ & 15 & 132 \\
\hline \multicolumn{5}{|c|}{ Rodovias do Paraná ( $76 \%$ rodovias federais) } \\
\hline $\begin{array}{l}\text { Região Londrina- } \\
\text { Sertanópolis }\end{array}$ & Econorte & & 24 & 275 \\
\hline $\begin{array}{l}\text { Região Maringá-Campo } \\
\text { Mourão }\end{array}$ & Viapar & & 24 & 545 \\
\hline $\begin{array}{l}\text { Região Foz do Iguaçu- } \\
\text { Cascavel-Guarapuava }\end{array}$ & Rodovia das Cataratas & & 24 & 459 \\
\hline $\begin{array}{l}\text { Região Guarapuava-Ponta } \\
\text { Grossa }\end{array}$ & Caminhos do Paraná & & 24 & 322 \\
\hline $\begin{array}{l}\text { RegiãoCuritiba-Ponta } \\
\text { Grossa-Apucarana }\end{array}$ & Rodonorte & & 24 & 568 \\
\hline Região Curitiba-Paranaguá & Ecovias & & 24 & 175 \\
\hline \multicolumn{5}{|l|}{ Rodovias do Santa Catarina } \\
\hline $\begin{array}{l}\text { Florianópolis (acesso às } \\
\text { praias) }\end{array}$ & Linha Azul & 1994 & 25 & 35 \\
\hline Brusque ${ }^{* *}$ & & & 25 & 126 \\
\hline BR-470** & & & 25 & 490 \\
\hline
\end{tabular}

Fonte: BNDES (nov. 2000); Folha de S. Paulo (25/8/2003)

* Ano de início da cobrança de pedágio

** O Tribunal de Contas do Estado de Santa Catarina julgou irregulares os contratos para o sistema Brusque e o Sistema BR 470. 
A gestão do governo Fernando Henrique teve fraca atuação na fiscalização do volume do tráfego nas rodovias e registros contábeis das concessionárias. Conforme relatório do Ministério dos Transportes, muitas delas não cumprem o cronograma de investimento, mas compensam o capital investido meses antes do reajuste do pedágio. Também não há fiscalização mais atuante por parte do governo quanto ao volume do tráfego nas rodovias e registros contábeis ${ }^{107}$.

A concessão de rodovias à iniciativa privada, conforme estabelecido nos contratos na segunda metade dos anos 1990 e inícIo dos anos 2000 gerou a maior taxação por quilômetro rodado, sem igual acompanhamento das melhorias nas condições de tráfego (duplicação de pistas, asfaltamento e sinalização de qualidade, etc). Entretanto, permitiu-se às concessionárias a taxação abusiva além da taxa de retorno do investimento de $19 \%$. As irregularidades constam desde os editais de concessão, aparentando serem "montados" para satisfazer o interesse das concessionárias ${ }^{108}$.

Conforme BNDES (nov. 2000), os pedágios cobrados pelas concessionárias nas rodovias estaduais ou federais promoveram forte insatisfação nos usuários e, principalmente, nos transportadores de carga. Em São Paulo, sindicatos dos transportadores de carga e usuários pressionaram o governo estadual para a reduzir as taxas cobradas nos pedágios, sem surtir grande efeito. No Paraná o governo diminuiu a tarifa em 50\%, no Rio Grande do Sul, em $20 \%$ a $28 \%$. O relatório do BNDES propunha, em 2000, que o governo estabelecesse "mecanismos de reavaliação periódica objetiva do contrato para o repasse, mesmo que parcial, de ganhos de produtividade visando à modicidade tarifária” (p. 15) ou, ainda, a "revisão periódica do contrato (incluindo também o tráfego) por prazo predeterminado" (p.16). Por fim, o BNDES sugere "para as concessões em andamento, estabelecimento, quando couber, de regras adicionais para atendimento dos princípios de defesa do consumidor" e necessidade de criação de Órgão Regulador das concessões (p. 19).

O BNDES também foi instrumento do Programa de Concessões Rodoviárias. Do total de investimento acordado com as concessionárias, R\$ 3,8 bilhões, o BNDES participa com aproximadamente um terço desse total ( $\mathrm{R} \$ 1,2$ bilhão).

\footnotetext{
${ }^{107}$ Folha de S. Paulo, 04/08/1999.

${ }^{108}$ Folha de S. Paulo, 25/08/2003.
} 


\section{Os portos}

Até 1990, a Portobrás, vinculada ao Ministério dos Transportes, companhias Docas e concessionárias, centralizava a administração dos portos. Em abril de 1990, através da Lei 8.029/90 foi extinta a Portobrás e o governo federal buscou repassar os 36 portos públicos para os estados e municípios. Dos 145 lotes ${ }^{109}$ arrendados, 30 provém do Porto de Santos (SP) - sendo aproximadamente 1/5 do total de área arrendada nos portos brasileiros.

O BNDES destinou R 920 milhões para o investimento em modernização, novos equipamentos, manutenção e melhorias nas instalações. Deste montante, $44 \%$ destina-se a região sudeste do país.

\section{III.3.1.2 A privatização do setor siderúrgico}

No início da década de 1990, o setor siderúrgico brasileiro era formado por empresas estatais, integradas na holding Siderbrás (Companhia Siderúrgica Paulista, Companhia Siderúrgica Nacional, Usiminas, entre outras), e por empresas privadas como Aços Gerdau, Belgo-Mineira, Aços Villares, etc., mas a predominância estatal era absoluta (Matos $\mathrm{F}^{\mathbf{o}} \mathrm{e}$ Oliveira, 1996, p. 16).

No decorrer da década de 1990 o setor foi totalmente privatizado: Usiminas, em 1991; Companhia Siderúrgica de Tubarão, em 1992; Companhia Siderúrgica Nacional, em 1993; Petroquímica União, em 1994; a Acesita para a Usinor, em 1998, etc.

Iniciar o processo com a privatização da Usiminas, sinalizava para o mercado que o governo estava determinado na consecução do Plano Nacional de Desestatização, que seria iniciado pelos setores de siderurgia, petroquímica e fertilizantes. Os recursos investidos nas principais empresas siderúrgicas - Usiminas, CSN, Acesita e CST - alcançaram US\$10,751 bilhões (Matos $\mathrm{F}^{\mathrm{o}}$ e Oliveira, 1996, p. 17), entretanto, os recursos arrecadados com a privatização, somando as transferências de dívidas, somaram US\$ 8,18 bilhões (BNDES, 2000).

Na tabela III.14 encontram-se dados referentes à privatização das principais empresas do setor.

${ }^{109}$ São os lotes: áreas de cais, armazéns, pátios, silos, áreas, instalações. 
Tabela III.14:

PRIVATIZAÇÃO DA SIDERURGIA

\begin{tabular}{|c|c|c|c|c|c|}
\hline Empresas & Data do leilão & $\begin{array}{l}\text { Receita de } \\
\text { venda }\end{array}$ & $\begin{array}{c}\text { Dívida } \\
\text { transferida }\end{array}$ & $\begin{array}{l}\text { Resultado } \\
\text { Geral }\end{array}$ & $\begin{array}{c}\text { Principais } \\
\text { Compradores }\end{array}$ \\
\hline Usiminas & $24 / 10 / 1991$ & $1.941,2$ & 369,1 & $2.310,3$ & $\begin{array}{c}\text { Bozano, CVRD, Previ, Valia, } \\
\text { Nippon Usiminas }\end{array}$ \\
\hline Cosinor & $14 / 11 / 1991$ & 15,0 & - & 15,0 & Gerdau \\
\hline Piratini & $14 / 02 / 1992$ & 106,7 & 2,4 & 109,1 & Gerdau \\
\hline CST & $16 / 07 / 1992$ & 353,6 & 483,6 & 837,2 & Bozano, CVRD e Unibanco \\
\hline Acesita & $22 / 10 / 1992$ & 465,4 & 232,2 & 697,6 & Previ, Sistel e Safra \\
\hline CSN & $02 / 04 / 1993$ & $1.495,3$ & 532,9 & $2.028,2$ & $\begin{array}{c}\text { Bamerindus, Vicunha, Docenave, } \\
\text { Bradesco, Itaú }\end{array}$ \\
\hline Cosipa & $20 / 08 / 1993$ & 585,7 & 884,2 & $1.469,9$ & Anquila e Brastudo, empregados \\
\hline Açominas & $10 / 09 / 1993$ & 598,6 & 121,9 & 720,5 & $\begin{array}{l}\text { Cia. Min. Part. Industrial, Banco } \\
\text { SRL, Empregados, Mendes Jr., } \\
\text { Aços Villares }\end{array}$ \\
\hline Total & - & $5.561,5$ & $2.626,3$ & $8.187,8$ & - \\
\hline
\end{tabular}

Fonte: BNDES, 2000 e Biondi, 1999. Elaboração do autor.

\section{III.3.1.3 A privatização do setor de telecomunicações}

O setor de telefonia e telecomunicações foi privatizado em julho de 1998, através daquele que foi festejado como o maior leilão de privatização realizado no país ${ }^{110}$, conforme a tabela III.15.

A Telebrás, a maior holding brasileira, foi dividida em 13 empresas para a privatização. Ela era avaliada pelo mercado, à época, em R $\$ 55$ bilhões ${ }^{111}$, e terminou sendo leiloada por R \$ 22 bilhões. A Embratel ficou com a MCI, por R \$ 2,65 bilhões.

\footnotetext{
${ }^{110}$ No dia do leilão, realizado na Bolsa de Valores do Rio de Janeiro, diversas lojas foram fechadas nas imediações da sede da Bolsa, dezenas de manifestantes ficaram feridos e cerca de 60 pessoas foram presas por causa dos protestos contrários à privatização (Folha de S. Paulo, 30/07/1998).

${ }^{111}$ Folha de S. Paulo, 18/01/1998.
} 
Tabela III.15:

Privatização das Telecomunicações - 1998

\begin{tabular}{|c|c|c|c|}
\hline Empresa & $\begin{array}{c}\text { Valor } \\
\text { (US\$ Bilhões) }\end{array}$ & $\begin{array}{l}\text { Compradores } \\
\text { (Participação em \%) }\end{array}$ & $\begin{array}{l}\text { Países } \\
\text { (Participação em } \\
\% \text { ) }\end{array}$ \\
\hline Telesp & 4,97 & $\begin{array}{l}\text { Telefônica S.a. e Subsidiárias: 56,6 } \\
\text { Telecon de Portugal: } 23 \\
\text { Iberdrola Investimentos: } 7 \\
\text { Banco Bilbao Vizcaya: } 7 \\
\text { RBS Participações: } 6,4\end{array}$ & $\begin{array}{l}\text { Espanha: } 70,6 \\
\text { Portugal: } 23 \\
\text { Brasil: } 6,4\end{array}$ \\
\hline Tele Centro-Sul Participações S.A. & 1,77 & $\begin{array}{l}\text { Timepart Part. Ltda: } 62 \\
\text { Stet International: } 19 \\
\text { Techold Part. S.A. (Opportunity, Previ, Sistel): } 19\end{array}$ & $\begin{array}{l}\text { Brasil: } 81 \\
\text { Itália: } 19\end{array}$ \\
\hline $\begin{array}{l}\text { Tele Norte-Leste Participações } \\
\text { S.A. }\end{array}$ & 2,94 & $\begin{array}{l}\text { Construtora Andrade Gutierrez: 21,20 } \\
\text { Inepar S.A. Ind. Const.: } 20 \\
\text { Macal Inv. e Part. S.A.: } 20 \\
\text { Fiago Part. S.A. (Funcef): } 18,70 \\
\text { Brasilseg: } 10,05 \\
\text { Cia de Seguros Aliança: } 10,05\end{array}$ & Brasil: 100 \\
\hline Embratel Participações S.A. & 2,27 & MCI Intenational: 100 & EUA: 100 \\
\hline Telesp Celular & 3,08 & Portelcom. Part. (Portugal Telecom) & Portugal: 100 \\
\hline $\begin{array}{l}\text { Tele Sudeste Celular Participações } \\
\text { S.A. }\end{array}$ & 1,16 & $\begin{array}{l}\text { Telefônica International: } 92,98 \\
\text { Iberdrola Investimentos: } 6,98 \\
\text { NTT Mobile Communications: } 0,02 \\
\text { Itochu Corporation: } 0,02\end{array}$ & $\begin{array}{l}\text { Espanha: } 99,96 \\
\text { Japão: } 0,04\end{array}$ \\
\hline $\begin{array}{l}\text { Telemig Celular Participações } \\
\text { S.A. }\end{array}$ & 0,65 & $\begin{array}{l}\text { Telesystem International Wireless Inc.: } 48 \\
\text { Opportunity: } 21 \\
\text { Fundos de Pensão (Previ e Sistel): } 18 \\
\text { Outros: } 13\end{array}$ & $\begin{array}{l}\text { Canadá: } 48 \\
\text { Brasil: } 52\end{array}$ \\
\hline $\begin{array}{l}\text { Tele Celular Sul Participações } \\
\text { S.A. }\end{array}$ & 0,60 & $\begin{array}{l}\text { UGB Participações (Globopar e Bradesco): } 50 \\
\text { Bitel Participações (Stet Mobile Holding): } 50\end{array}$ & $\begin{array}{l}\text { Brasil: } 50 \\
\text { Itália: } 50\end{array}$ \\
\hline $\begin{array}{l}\text { Tele Nordeste Celular } \\
\text { Participações S.A. }\end{array}$ & 0,57 & $\begin{array}{l}\text { UGB Participações (Globopar e Bradesco): } 50 \\
\text { Bitel Participações (Stet Mobile Holding): } 50\end{array}$ & $\begin{array}{l}\text { Brasil: } 50 \\
\text { Itália: } 50\end{array}$ \\
\hline $\begin{array}{l}\text { Tele Leste Celular Participações } \\
\text { S.A. }\end{array}$ & 0,37 & $\begin{array}{l}\text { Iberdrola Energin S.A. } \\
\text { Telefônica International S.A. (Tisa) }\end{array}$ & Espanha: 100 \\
\hline $\begin{array}{l}\text { Tele Centro-Oeste Participações } \\
\text { S.A. }\end{array}$ & 0,38 & Splice & Brasil: 100 \\
\hline Tele Norte Participações S.A. & 0,16 & $\begin{array}{l}\text { Telesystem International Wireless Inc.: } 48 \\
\text { Opportunity: } 21 \\
\text { Fundos de Pensão (Previ e Sistel): } 18 \\
\text { Outros: } 13\end{array}$ & $\begin{array}{l}\text { Canadá: } 48 \\
\text { Brasil: } 52\end{array}$ \\
\hline
\end{tabular}

Fonte: BNDES, 1999b.

A Telebrás, disputada por algumas das maiores empresas mundiais do setor, era a empresa mais lucrativa do país, a $15^{\mathrm{a}}$ empresa de telefonia do mundo e a maior da América Latina. Em 1997, obteve um lucro de US\$ 3,9 bilhões, enquanto a Fiat, a título de comparação, lucrou no mesmo ano US\$ 472 milhões ${ }^{112}$. Pesquisa do Instituto de Pesquisas Datafolha, realizada no mês da privatização, indicava que $51 \%$ dos entrevistados eram

\footnotetext{
${ }^{112}$ Os dados do desempenho da empresa parecem contradizer um dos mitos referentes à privatização, que afirmava ser um estímulo a eficiência, conforme Browne (1988, p. 106)
} 
contrários ao negócio, enquanto os favoráveis seriam $41 \%{ }^{113}$. Os estrangeiros ficaram com $32 \%$ da telefonia fixa e $79 \%$ da telefonia celular.

O setor de telecomunicações, também no Brasil, tem sido o alvo de diversos negócios. Em 2002, por exemplo, foi formada a Brasilcel, uma joint venture entre a espanhola Telefonica Móviles e a Portugal Telecom (PT), que no início de 2003 adquiriu a Tele Centro Oeste Participações (TCO), por $€ 404$ milhões, tornando-se a maior operadora de telefonia móvel da América Latina (GZM, 17/01/2003). Ressalte-se que a TCO resulta da anterior fusão entre as empresas: Telegoiás, Telemat, Telems, Teleacre e Teleron, além de ter adquirido a Telebrasília.

A Claro, empresa da holding Telecom Américas, resulta da aquisição da BCP (em 2003) e da união das operadoras Americel, ATL, BCP, Claro Digital e Tess, totalizando cerca de 3 milhões de assinantes no estado de São Paulo.

Em 2004, o destino da Embratel foi proferido pela justiça norte-americana, que por causa da falência da antiga proprietária, a MCI, favoreceu a empresa mexicana Telmex (que pagou US\$ 400 milhões pela Embratel) na contenda com o consórcio Calais Participações, formado entre as operadoras de telefonia fixa Telemar, Brasil Telecom e Telefônica, na disputa pela Embratel. A Telmex, proprietária da Telet e Americel (empresas do grupo Claro, que atuam no Rio Grande do Sul e na região Centro-Oeste) também adquiriu, em fevereiro de 2004 os ativos da AT\&T Latin America no Brasil, e tem interesse na aquisição de parte da Net Serviços, maior operadora de TV por assinatura do país pertencente ao grupo Globo de Televisão ${ }^{114}$.

\footnotetext{
${ }^{113}$ Folha de S. Paulo, 25/07/1998.

${ }^{114}$ Folha de S. Paulo, 15/05/2004.
} 


\section{Mapa III.1}

\section{DIVISÃO REGIONAL DAS PRINCIPAIS EMPRESAS DE TELECOMUNICAÇÕES - 2003}

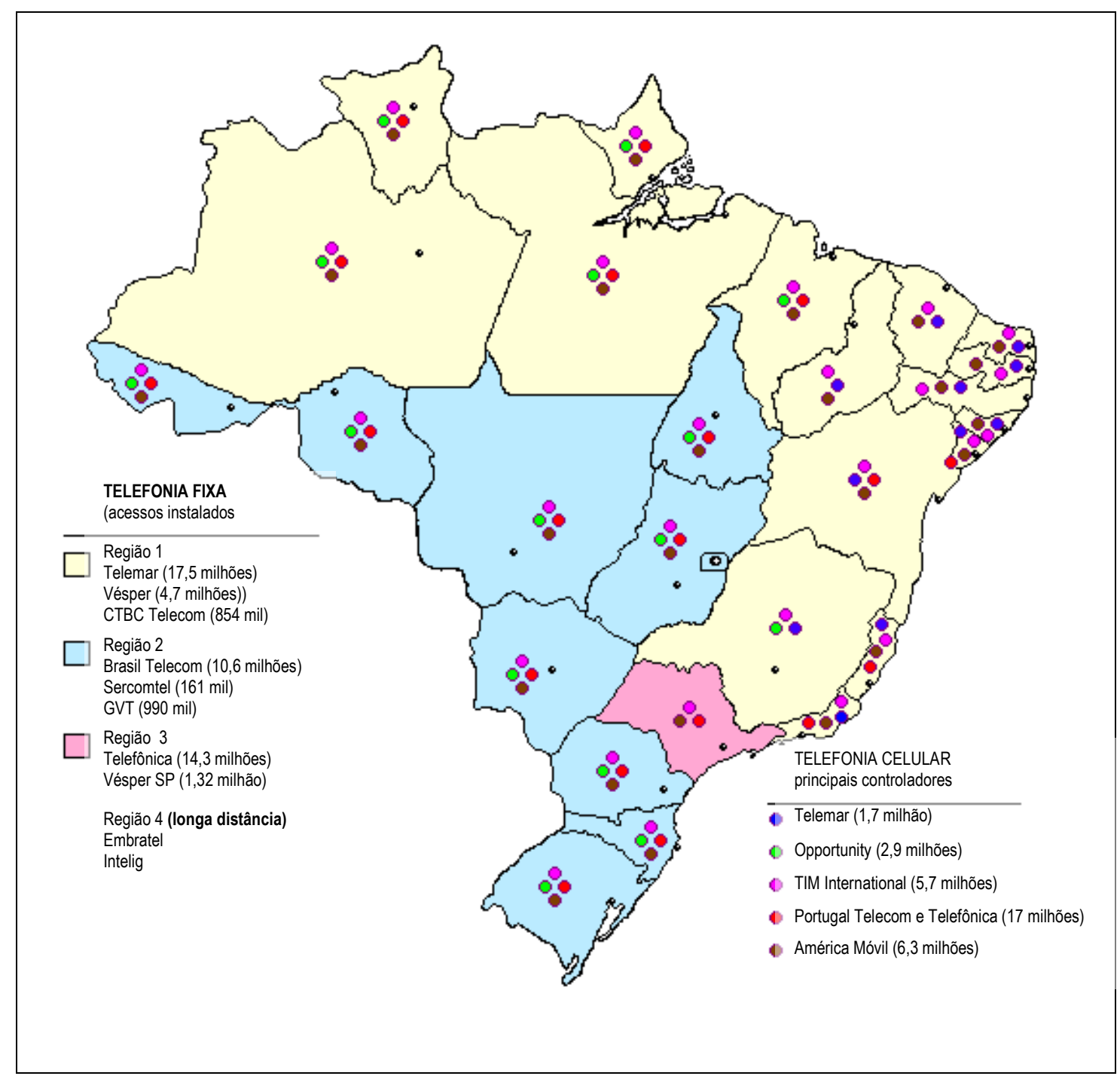

Telefonia celular

\begin{tabular}{|l|l|c|}
\hline \multicolumn{1}{|c|}{ Principais controladores } & \multicolumn{1}{|c|}{ Marca/operações regionais } & Base de assinantes \\
\hline Telemar & Oi & 1,7 milhão \\
\hline Opportunity & Telemig Celular, Amazônia Celular e Brasil Telecom Celular & 2,9 milhões \\
\hline TIM International & TIM Nordeste, TIM Sul, TIM Maxitel e TIM Brasil. & 5,7 milhões \\
\hline Portugal Telecom e Telefonica & $\begin{array}{l}\text { Vivo - Celular CRT, Telefônica Celular. } \\
\text { Telesp Celular, TCO, NBT e Global Telecom }\end{array}$ & 17 milhões \\
\hline América Móvil & Telecom Américas - BSE, Telet, Americel, ATL e Tess & 6,3 milhões \\
\hline Telecom Américas & Claro = (BCP-SP + Americel +ATL+Claro Digital e Tess) & 3 milhões (em SP) \\
\hline Algar & CTBC Celular (Triângulo Mineiro) & 300 mil \\
\hline Prefeitura de Londrina & Sercomtel (Paraná) & - \\
\hline Qualcomm & Vésper (nordeste e sudeste) & - \\
\hline
\end{tabular}

Fonte: Gazeta Mercantil (29/7/2003) 


\section{III.3.1.4 A privatização do setor de energia elétrica}

O setor elétrico brasileiro era constituído, em 1995, por 64 concessionárias (55 distribuidoras, 5 companhias mistas e 4 geradoras, inclusive Itaipu). Nesse mesmo ano, a participação do capital privado nas concessionárias era de $2,7 \%$, enquanto a participação das concessionárias públicas era de 97,3\%. O setor foi aberto, através das privatizações, e então a participação do capital privado elevou-se para $22 \%$ na geração de energia e para $63 \%$ na distribuição em $2000^{115}$.

As primeiras empresas do setor elétrico a serem vendidas foram as empresas distribuidoras, de acordo com o seguinte cronograma:

- A primeira empresa a ser vendida foi a Escelsa, em 1995;

- em 1996 foram privatizadas a Light e a Cerj, por US\$ 588 milhões, para um consórcio formado por: EDP-Eletricidade (Portugal, 30\%), Empresas Electricas de Panamá (Chile, 30,6\%); Endesa Desarrollo (Espanha, 10,0\%); e Sociedade Panamenha de Eletricidade (Chile, 29,4\%);

- Em 1997 foram privatizadas as distribuidoras: Cemat; Coelba (por US\$ 1598 milhões, para a Iberdrola, Espanha, 39\%); CPFL, Enersul, Cosern, Energipe, AES Sul; RGE; CDSA - Centrais Elétricas Cacheira Dourada AS, por US\$ 714 milhões, para Endesa (Chile), 60\% ${ }^{116}$;

- Em 1998 ocorreu a privatização da Eletropaulo e de parte da Cesp, quando o volume da distribuição de energia pelo setor privado atingiu 63\%. Em setembro ocorreu a privatização da Gerasul (antiga Eletrosul);

- Em 1999 ocorreu a privatização da Celb, e de duas geradoras de São Paulo (após a divisão da Cesp): Tietê e Paranapanema;

- Em 2000, ocorreu a privatização de duas distribuidoras: Celpe e Cemar.

A privatização iniciou-se pelo setor de distribuição "para reduzir o risco percebido de um rompimento financeiro dos contratos por parte dessas empresas"117.

\footnotetext{
115 BNDES, 2000b.

${ }^{116}$ Dados sobre participação estrangeira extraídos de Gonçalves, 1999, p. 146-147.

${ }^{117}$ BNDES, 2000b, p. 13.
} 
No histórico do setor elétrico, evidencia-se uma expansão nos anos 60 e 70, que se prolongou até o final da década seguinte, quando uma série de restrições atingiu as empresas estatais do setor, como por exemplo a diminuição do acesso a recursos externos, a extinção do IUEE (Imposto Único sobre Energia Elétrica) ${ }^{118}$, contenção tarifária, além da restrição ao crédito interno ${ }^{119}$, inclusive com a proibição das empresas estatais obterem recursos e financiamentos juntos ao $\mathrm{BNDES}^{120}$, o que dificultou o desempenho e prejudicou os resultados de diversas empresas estatais, inclusive as do setor de energia elétrica. Mas foi no governo de Fernando Henrique, em maio de 1997, que ocorreu a reviravolta inconcebível: o BNDES foi autorizado a conceder empréstimos para empresas estrangeiras comprarem as empresas estatais, enquanto permanecia a proibição de financiar as estatais nacionais ${ }^{121}$, uma distorção em relação à idéia de criação do BNDES, voltado para o desenvolvimento do país e para o fortalecimento de grupos nacionais. Conforme Biondi (1999), na semana posterior à autorização dada ao BNDES por FHC, um grupo dos EUA “comprou um bloco de um terço das ações da Cemig por R\$ 2 bilhões, com metade desse valor financiado pelo BNDES” (p. 36).

Além disso, por exemplo, em relação às tarifas, o governo dizia que seriam reduzidas para benefício do consumidor, mas concordava com reajustes anuais pelo prazo de 8 anos, indexados ao IGP-DI; o governo concordou com a importação de máquinas, peças e equipamentos dos países de origem das empresas adquirentes das estatais; as empresas ficaram livres de investirem capital próprio no país, podendo levantar empréstimos no exterior, e assim aumentar o passivo do Brasil; o governo abandonou o modelo original, de gestão compartilhada para agente fiscalizador do setor, assim ampliando a margem de autonomia das empresas e das suas matrizes. Foi criada a figura do Operador do Sistema Nacional - OSN, formado conforme o jargão do governo, por um "condomínio" de empresas privatizadas, ou "operadoras", cuja responsabilidade não se restringe apenas ao sistema de transmissão, mas à época de FHC tinha a incumbência também de "decidir onde, quando e como devem ser construídas usinas, quais as regiões prioritárias, etc.” (Biondi, 1999, p. 37). O governo, na melhor das hipóteses, declinou de seu papel de organização e planejamento de

\footnotetext{
${ }^{118}$ Chuay e Victer, 2002, p. 33.

119 BNDES, 2000b, p. 7.

120 "Por incrível que pareça, repita-se, em 1989 surgiu um decreto do Presidente da República, nunca revogado, pura e simplesmente proibindo o banco oficial, o BNDE (hoje BNDES), de realizar empréstimos a empresas estatais" (Biondi, 1999, p. 19).

${ }^{121}$ Biondi, 1999, p. 36.
} 
um setor tão importante para o desenvolvimento, portanto um setor realmente "estratégico" para o país ${ }^{122}$.

Conforme Gonçalves (1999), as privatizações e desregulamentações determinaram a entrada do capital estrangeiro no setor, no Brasil, após 1995, diante de uma situação de potencial crescimento do mercado de energia no país, e de mudanças nas estratégias das empresas internacionais no que se refere a diversificação geográfica (p. 170). Assim, por exemplo, para a empresa Southern Electric, dos EUA, a prioridade são as empresas do setor de geração de energia, assim como para a EDP (Portugal) e EDF (França), enquanto para a Iberdrola (Espanha), o interesse maior concentra-se em áreas de infra-estrutura, com participação minoritária na Cerj (RJ), com o controle da Coelba (BA) e da Cosern (RN), além de participações em empresas de telefonia e de gás (p. 171).

\section{III.3.2 Casos de empresas privatizadas}

Muitas das empresas estatais privatizadas, bem como das empresas privadas vendidas, são casos passíveis de estudos minuciosos. No âmbito deste trabalho, algumas dessas empresas foram escolhidas para exemplificar o processo ocorrido no Brasil. São elas: Companhia Vale do Rio Doce (CVRD) e Embraer, privatizadas; American Beverage (Ambev), caso de fusão entre a cervejarias Brahma e a Companhia Antarctica; Grupo Votorantim, caso de empresa brasileira que se expandiu nos anos 1990, Construtora Norberto Odebrecht; Grupo Gerdau e WEG.

\footnotetext{
${ }^{122}$ De acordo com Chuay e Victer (2002, p. 41), já no ano de 1996 foi contratada uma consultoria inglesa, chamada Coopers \& Lybrand Consultant Ltd, incumbida da elaboração do novo modelo do setor elétrico. Da mesma forma, "Os planos para o setor passariam a ser indicativos e não mais impositivos. O planejamento setorial, administrado pela Eletrobrás, com o apoio do Grupo Coordenador de Planejamento do Sistema, foi seriamente prejudicado com a sua extinção. Dentro de uma política já adotada pelo governo, foi criada a Agência Nacional de Energia Elétrica - ANEEL, que viria a absorver as funções do antigo Departamento Nacional de Energia Elétrica - DNAEE, relativamente à regulamentação e fiscalização do setor. Tratava-se da instituição de uma autarquia especial, cujo presidente não seria demissível por um período de 3 anos, num falso arremedo de independência. Sua ação regulamentadora e fiscalizadora careceu de efetivo poder e transcendeu suas atribuições, por muitas vezes fazendo a política do setor devido ao enfraquecimento e esvaziamento progressivo do Ministério de Minas e Energia" (p. 42). Biondi (1999) afirma: "O problema de tarifas e qualidade de serviços ficou com a Agência de Energia Elétrica, do governo. O resto, com a OSN, das operadoras. Para que Ministério? O governo não manda nada mais mesmo. Nem governa mais." (p. 37).
} 


\section{III.3.2.1. A Companhia Vale do Rio Doce (CVRD)}

\section{Breve Histórico}

A história da Companhia Vale do Rio Doce (CVRD), remonta aos primeiros anos do século XX, quando foi fundada a Companhia Estrada de Ferro Vitória a Minas (1904), posteriormente incorporada à britânica Brazilian Hematite Syndicate, (exploração de minério). A união permitiu, em 1910, a ampliação da ferrovia até Itabira, aonde chegou em 1943. Em 1911 a Brazilian Hematite Syndicate transformou-se na Itabira Iron Ore Company, controlada por Percival Farquhar, e 3 décadas depois realizou o primeiro embarque de minério de ferro pelo Porto de Vitória. Em seguida, a Itabira Iron foi dividida em duas empresas: a Companhia Brasileira de Mineração e Siderurgia e a Companhia Itabira de Mineração.

Como consequiência dos Acordos de Washington e através do decreto-lei $\mathrm{n}^{\circ} 4.352$, em $1^{\circ}$ de junho de 1942 o presidente Getúlio Vargas criou a Companhia Vale do Rio Doce. A nova empresa, uma sociedade anônima de economia mista, encampou a Estrada de Ferro Vitória-Minas e as empresas de Farquhar. Em 1943 a CVRD fixou a sua sede em Itabira e o domicílio jurídico no Rio de Janeiro, e a empresa foi registrada na Bolsa de Valores do Rio de Janeiro. Seis anos depois a empresa exportava $80 \%$ do minério de ferro produzido no Brasil. Mas, o governo brasileiro somente assumiu o controle definitivo do sistema operacional da CVRD em 1952. No ano seguinte comercializou com o Japão e passou a utilizar transporte brasileiro para comercializar com os EUA.

- A década de 1960 iniciou-se com a criação da Companhia Siderúrgica Vatu, a primeira subsidiária da CVRD para beneficiar minérios, fabricar e comercializar ferro-esponja.

- Em 1962 estabeleceu contratos de longo prazo com siderúrgicas japonesas e usinas alemãs. Em 2 de outubro foi criada a Vale do Rio Doce Navegação S.A. (Docenave).

- Em 1966 foi inaugurado o Porto de Tubarão.

- Em 1967 descobriu-se minério de ferro em Carajás (por Geólogos da Cia. Meridional de Mineração, subsidiária da United States Steel Corp). No ano seguinte, a empresa foi registrada na Bolsa de Valores de São Paulo (BOVESPA). Em 1969, inaugurou a Usina de Pelotização em Tubarão. 
- Na década de 1970 a empresa tornou-se sócia majoritária de Carajás, em empreendimento com a US Steel Co. Em seguida foi fundada a Rio Doce Geologia e Mineração S.A. (Docegeo), subsidiária da CVRD, com o objetivo de pesquisar minérios.

- Em 1972 a CVRD e a US Steel constituíram a Valuec Serviços Técnicos, para analisar a viabilidade do Projeto Carajás. A CVRD conveniou-se com a Alcan Aluminiun Ltd., em projeto de exploração de bauxita na área do rio Trombetas. Inaugurou, em 1973, a primeira fase da Usina de Concentração de Itabirito.

- Em 1974 a empresa se tornou a maior exportadora de minério de ferro do mundo, detendo $16 \%$ do mercado transoceânico do minério.

- Em 1975, com intermediação do Dresdner Bank, a CVRD lançou debêntures no mercado internacional, no valor de 70 milhões de marcos.

- Em 1978 o Projeto Carajás foi reformulado e iniciou-se a construção da Estrada de Ferro Carajás (concluída em 1985).

- Em 1980, a CVRD incorporou a Amazônia Mineração (Amza), e criou a Superintendência de Implantação do Projeto Ferro Carajás (Sumip), dando início à mineração em 1981. Com o início das operações da Valesul Alumínio S.A. (no estado do Rio de Janeiro) em 1982, a CVRD entrou no segmento de alumínio, reduzindo as importações do metal.

- Em 1985, com a Estrada de Ferro a empresa aumentou sua capacidade produtiva, e se estruturou em dois sistemas logísticos distintos (Norte e Sul), cada qual com seu complexo mina-ferrovia-porto.

- Em 1986 iniciaram-se as operações no Terminal Portuário de Ponta da Madeira, em São Luís (MA).

- Em 1988 a CVRD passou a utilizar carvão vegetal de sua própria área de reflorestamento, buscando a auto-suficiência.

- Em 1990 foi inaugurado o laboratório florestal de Linhares (ES), equipado para análises de solo, sementes, entomologia, pesquisas de biotecnologia (cultura de tecidos), etc..

- Em 1994, a CVRD lançou seu programa de American Depositary Receipts negociáveis nos EUA. No ano seguinte a empresa foi incluída no Programa Nacional de Desestatização (Decreto ${ }^{\circ} 1.510$, de $1^{\circ}$ de junho de 1995), ou seja, nos primeiros meses do governo de Fernando Henrique. 


\section{A privatização da CVRD}

Em 6 de maio de 1997, a CVRD foi leiloada na Bolsa de Valores do Rio de Janeiro. Dois consórcios participaram do leilão de privatização: o Valecom, liderado pelo Grupo Votorantim, e o Consórcio Brasil (CSN), que arrematou 41,73\% das ações ordinárias da CVRD por R 3.338 milhões, correspondendo a $\mathrm{R}$ \$ 32,00 por ação, com 19,99 \% de ágio sobre o preço mínimo ${ }^{123}{ }^{124}$. Benjamin Steinbruch, presidente da CSN, foi nomeado presidente do Conselho de Administração da CVRD, e um representante da Previ foi nomeado seu vice-presidente.

- Após a privatização, a CVRD continuou crescendo, e em 1998 a empresa atingiu crescimento de $46 \%$ em seu lucro (referente a 1996). Ainda em 1998, através do Programa de Demissões lncentivadas, em apenas dois meses, foram cortados 3.300 funcionários $^{125}$.

- Em 1999 a CVRD obteve o maior lucro de sua história até então: R\$ 1,251 bilhão.

- Em 2000 foi inaugurado o Terminal de Contêineres do Porto de Sepetiba e a empresa foi registrada na Latibex e na New York Stock Exchange (NYSE). Dois anos depois, obteve um resultado na balança comercial de R \$ 2,8 bilhões, e exportou US\$ 3,17 bilhões.

- Em 2004 as ações da CVRD atingiram um alto rendimento, e a empresa valorizou-se alcançando um valor superior a $\mathrm{R} \$ 23$ bilhões no mercado.

- A CVRD atua nas áreas de mineração, logística e energia, em 14 estados brasileiros, além de abastecer o mercado internacional, exportando seus minérios para diversos países.

- A CVRD aumentou sua participação no cenário mundial, em um mercado considerado como altamente disputado.

- A CVRD é proprietária de reservas minerais de alta qualidade, além de possuir moderna infra-estrutura e um sistema logístico extremamente eficiente (ferrovia, porto e navegação). Concentrou sua atuação em mineração, logística e energia elétrica, e sua estratégia é a de posicionar-se entre as três maiores mineradoras do mundo.

- A CVRD possui empresas (controladas e coligadas) em diversos países, tais como: Estados Unidos, Argentina, Chile, Peru, França, etc. Seus negócios estão relacionados

${ }^{123}$ O consórcio adquirente assumiu, ainda, dívidas no valor de US\$ 3,559 bilhões (O Estado de S. Paulo, 23/10/2004).

${ }^{124}$ No endereço eletrônico da empresa, informa-se que "O preço total da CVRD, implícito no lance final, era de R\$ 12,5 bilhões" (www.cvrd.com.br, acessado em 23/05/2004).

${ }^{125}$ Folha de S. Paulo, 05/01/1998. 
com a venda de minério de ferro e pelotas através das seguintes empresas: RDA, responsável pela América do Norte e América Central; RDI, sediada em Bruxelas, responsável pela Europa, África, Oriente Médio, Iran, Índia e Paquistão; RDASIA I, com sede em Tóquio, responsável pela Ásia, com exceção da China; RDASIA II, com sede em Xangai, responsável pela China; e Gevac - Gerência Geral de Vendas para a América do Sul.

- Em 2002 a CVRD inaugurou a Usina de Pelotização de São Luís e lançou a pedra fundamental do Projeto Sossego, entrando, portanto, na exploração de cobre. O Projeto Grande Carajás completou 35 anos de operação e a CVRD atingiu seu maior índice de produção de minério de ferro: 5 milhões de toneladas.

Uma série de transações realizadas pela Companhia nos últimos anos é encontrada na tabela III.16, a seguir, que indica a estratégica da CVRD em deixar o setor siderúrgico e concentrar-se em mineração e logística.

\section{Tabela III.16}

NEGÓCIOS COM PARTICIPAÇÃO DA CVRD (A PARTIR DE 2000)

\begin{tabular}{|c|c|c|c|c|}
\hline Data & Empresas(s) envolvida(s) & Empresa adquirida & Tipo de transação & Estratégia \\
\hline Maio/00 & $\begin{array}{l}\begin{array}{l}\text { CVRD } \\
(\text { Samitri })\end{array} \\
\end{array}$ & Samitri & 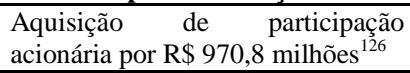 & $\begin{array}{l}\text { Belgo Mineira volta-se } \\
\text { para a siderurgia. }\end{array}$ \\
\hline $\begin{array}{l}\text { Outubro/ } \\
00\end{array}$ & 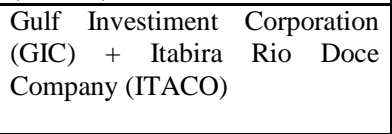 & $\begin{array}{ll}\text { Gulf } & \text { Industrial } \\
\text { Investiment } & \text { Company } \\
\text { (GIIC) } & \end{array}$ & Aquisição acionária & $\begin{array}{l}\text { Reforço do "core } \\
\text { business" e aumentar } \\
\text { competitividade } \\
\text { internacional }\end{array}$ \\
\hline Maio/00 & CVRD & Mineração Socoimex S.A. & Aquisição do capital & 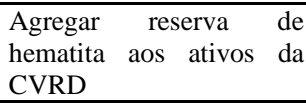 \\
\hline N.D. & $\begin{array}{l}\text { Thiele Kaolim Company (TKC) } \\
\text { e Pará Pigmentos S.A. (PPSA) }\end{array}$ & $\begin{array}{lr}\text { TKC } & \text { adquiriu } \\
\text { participação } & \text { minoritária } \\
\text { na PPSA } & \\
\end{array}$ & $\begin{array}{l}\text { CVRD garantiu exclusividade para } \\
\text { a TKC representar a PPSA na } \\
\text { América do Norte }\end{array}$ & $\begin{array}{l}\text { Entrada no mercado de } \\
\text { caulim da América do } \\
\text { Norte }\end{array}$ \\
\hline $\begin{array}{l}\text { Dezembr } \\
\mathrm{o} / 00\end{array}$ & CVRD + Açominas & $\begin{array}{l}\text { Troca de ações em poder } \\
\text { da Açominas (da Gerdau) } \\
\text { por ações da Açominas } \\
\text { em poder da CVRD }\end{array}$ & Contrato de permuta de ações & $\begin{array}{l}\text { Vender ações da Gerdau } \\
\text { na melhor oportunidade }\end{array}$ \\
\hline 2001 & $\begin{array}{|lcc|}\text { Florestas Rio Doce (FRD), } \\
\text { ITACO e Cia. Suzano de Papéis }\end{array}$ & N.D. & Transferência de posição acionária & N.D. \\
\hline $\begin{array}{l}\operatorname{Março/20} \\
01\end{array}$ & CVRD +CSN & N.D. & $\begin{array}{l}\text { Descruzamento de participação } \\
\text { acionária }\end{array}$ & $\begin{array}{l}\text { Interesse da CVRD em } \\
\text { concentrar-se nos setores } \\
\text { de mineração e logística }\end{array}$ \\
\hline $\begin{array}{l}\text { Abril/200 } \\
1\end{array}$ & $\begin{array}{l}\text { CVRD + Thyssen Krupp Stahl } \\
\text { AG (TKS) }\end{array}$ & Ferteco (TKS) & Aquisição de $100 \%$ & $\begin{array}{l}\text { Ganhos com serviços de } \\
\text { transporte e logística, } \\
\text { racionalização } \\
\text { operação das minas da } \\
\text { Ferteco, portanto, reforço } \\
\text { da estratégia comercial da } \\
\text { CVRD }\end{array}$ \\
\hline $\begin{array}{l}\text { Agosto/2 } \\
001\end{array}$ & CVRD +Baosteel & Anúncio da associação & N.D. & $\begin{array}{l}\text { Assegurar } \\
\text { relevante no merção } \\
\text { chinês, para venda de } \\
\end{array}$ \\
\hline
\end{tabular}

${ }^{126}$ O Estado de S. Paulo, 31/05/2000. 


\begin{tabular}{|c|c|c|c|c|}
\hline & & & & minério de alta qualidade \\
\hline $\begin{array}{l}\text { Setembro } \\
/ 01\end{array}$ & $\begin{array}{l}\text { Cenibra (ITACO/CVRD) }+ \\
\text { Japan Brazil Paper and Pulp } \\
\text { Resources Development (JBP) }\end{array}$ & $\begin{array}{|llll|}100 \% & \text { da } & \text { Cenibra } & \text { pela } \\
\text { JBP } & & & \\
\end{array}$ & $\begin{array}{l}\text { Venda da totalidade da ações do } \\
\text { capital social da Cenibra, em poder } \\
\text { da ITACO, para a JBP } \\
\end{array}$ & N.D. \\
\hline $\begin{array}{l}\text { Setembro } \\
/ 01\end{array}$ & $\begin{array}{l}\text { CVRD, Bethlehem e Bethlehem } \\
\text { International }\end{array}$ & Belém & $\begin{array}{l}\text { Aquisição da Belém (Bethlehem e } \\
\text { Bethlehem International) }\end{array}$ & $\begin{array}{l}\text { Fortalece posição da } \\
\text { CVRD no minério de } \\
\text { ferro, pois a Belém tem } \\
\text { participação na MBR } \\
\text { (produtora de minério de } \\
\text { ferro) }\end{array}$ \\
\hline $\begin{array}{l}\text { Outubro/ } \\
01\end{array}$ & CVRD & N.D. & $\begin{array}{l}\begin{array}{l}\text { Aquisição do Projeto Sossego } \\
\text { (Mina de Cobre) }\end{array} \\
\end{array}$ & \begin{tabular}{|lr} 
Oportunidade & de \\
crescimento & e \\
rentabilidade configurada \\
na ampliação da \\
mineração voltada para o \\
cobre \\
\end{tabular} \\
\hline $\begin{array}{l}\text { Outubro/ } \\
01\end{array}$ & CVRD+Baosteel & N.D. & $\begin{array}{l}\text { Associação para criação de nova } \\
\text { empresa no Brasil (BAOVALE } \\
\text { MINERAÇÃO S.A.) }\end{array}$ & $\begin{array}{l}\text { Assegurar } r \\
\text { relevante no mesição } \\
\text { chinês, para venda de } \\
\text { minério de alta qualidade }\end{array}$ \\
\hline $\begin{array}{l}\text { Outubro/ } \\
01\end{array}$ & CVRD+Mitsui & $\begin{array}{l}\text { Caemi (negócio concluído } \\
\text { em } 31 \text { de março/2003, por } \\
\text { US\$ 426,4 milhões) }\end{array}$ & $\begin{array}{l}\text { Aquisição do controle acionário } \\
\text { (50\% para } \\
\text { envolvidas) }\end{array}$ & $\begin{array}{l}\text { consolidação da estratégia } \\
\text { de participaçào da CVRD } \\
\text { na indústria global de } \\
\text { minério de ferro, pois a } \\
\text { Caemi é a 4a produtora } \\
\text { mundial de minério de } \\
\text { ferro }\end{array}$ \\
\hline $\begin{array}{l}\text { Novembr } \\
\mathrm{o} / 01\end{array}$ & CVRD+CODELCO & N.D. & $\begin{array}{l}\text { Acordo para desenvolvimento de } \\
\text { estudo visando associação entre a } \\
\text { maior produtora mundial de } \\
\text { minério de ferro e a maior } \\
\text { produtora mundial de cobre } \\
\end{array}$ & \begin{tabular}{|l|} 
estratégia de \\
fortalecimento da \\
expansão internacional \\
das empresas na indústria \\
de cobre \\
\end{tabular} \\
\hline $\begin{array}{l}\text { Maio- } \\
\text { junho/02 }\end{array}$ & CVRD/Anglo American plc & Projeto & $\begin{array}{l}\text { Participação acionária da Anglo no } \\
\text { Projeto Salobo. CVRD torna-se } \\
\text { proprietária de } 100 \% \text { do Projeto. }\end{array}$ & $\begin{array}{l}\text { consolida posição da } \\
\text { CVRD na exploração e } \\
\text { produção de cobre } \\
\text { (estima-se que o Projeto } \\
\text { possua } 784 \text { milhões de } \\
\text { toneladas de cobre) } \\
\end{array}$ \\
\hline Julho/02 & \begin{tabular}{|lll|}
\multicolumn{2}{|l|}{ Aluvale(CVRD)/ } & \\
$\begin{array}{l}\text { Mineração } \\
\text { (Paranapanema) }\end{array}$ & Cruz \\
(ana & \\
\end{tabular} & Mineração Vera Cruz & Aquisição acionária & $\begin{array}{l}\text { Ampliação dos negócios } \\
\text { com alumínio, através da } \\
\text { exploração de bauxita e } \\
\text { alumina }\end{array}$ \\
\hline Julho/02 & CVRD/Antofagasta Plc & & $\begin{array}{l}\text { Joint Venture para constituição de } \\
\text { empresa (Cordillera de las Minas } \\
\text { S.A.) voltada para pesquisa e } \\
\text { exploração no Peru }\end{array}$ & \begin{tabular}{|lr} 
Movimento & de \\
internacionalização da & da \\
CVRD, reiterando seu \\
interesse pela mineração \\
de cobre \\
\end{tabular} \\
\hline $\begin{array}{l}\text { Janeiro/0 } \\
3\end{array}$ & CVRD/Mitsui & & & $\begin{array}{l}\text { associação com o objetivo } \\
\text { de desenvolver negócio } \\
\text { de transporte intermodal }\end{array}$ \\
\hline $\begin{array}{l}\text { Fevereiro } \\
/ 03\end{array}$ & 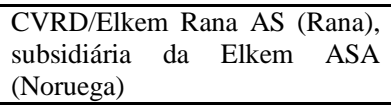 & Elkem Rana AS & $\begin{array}{l}100 \% \text { do capital da empresa } \\
\text { norueguesa, por US } \$ 17,6 \text { milhões }\end{array}$ & $\begin{array}{l}\text { expansão da CVRD com } \\
\text { ferro ligas na Europa }\end{array}$ \\
\hline Março/03 & $\begin{array}{l}\text { CVRD+Arcelor/ } \\
\text { CST+Acesita }\end{array}$ & CST & $\begin{array}{l}\text { participação acionária de empresas } \\
\text { controladas da Acesita na CST }\end{array}$ & $\begin{array}{l}\text { CVRD visa participar da } \\
\text { reestruturação } \\
\text { siderurgia com vistas a } \\
\text { expandir seus negócios } \\
\text { relativos a minerais } \\
\text { ferrosos, por conta de } \\
\text { construção de mais um } \\
\text { alto forno na CST } \\
\end{array}$ \\
\hline Julho/03 & CVRD/Yamana Resources Inc & $\begin{array}{l}\text { mina de ouro "Fazenda } \\
\text { Brasileiro" (CVRD) }\end{array}$ & venda & \begin{tabular}{|l|} 
CVRD se desfaz de mina, \\
interrompendo sua \\
participação.
\end{tabular} \\
\hline $\begin{array}{l}\text { Agosto/0 } \\
3\end{array}$ & CVRD/Celmar & N.D. & $\begin{array}{l}\text { incorporação da Celmar S.A. Ind. } \\
\text { de Celulose e Papel }\end{array}$ & N.D. \\
\hline $\begin{array}{l}\text { Agosto/0 } \\
3\end{array}$ & CVRD/Ferteco & N.D. & Incorporação da Ferteco & N.D. \\
\hline $\begin{array}{l}\text { Outubro/ } \\
03\end{array}$ & \begin{tabular}{|l} 
Bunge Fertilizantes/ \\
Fosfértil (CVRD)
\end{tabular} & Fosfértil & Venda & $\begin{array}{l}\text { Estratégia alinhada com o } \\
\text { objetivo da CVRD em }\end{array}$ \\
\hline
\end{tabular}




\begin{tabular}{|l|l|l|l|l|}
\hline & & & & $\begin{array}{l}\text { mineração e logística, } \\
\text { além da venda das suas } \\
\text { participaçós em } \\
\text { empreendimentos que se } \\
\text { tornaram investimento de } \\
\text { portf́lio }\end{array}$ \\
\hline $\begin{array}{l}\text { Janeiro/0 } \\
4\end{array}$ & CVRD/ & N.D. & $\begin{array}{l}\text { Incorporação das empresas: } \\
\text { Docegeo, } \\
\text { MSS, Aluvale e MVC }\end{array}$ & $\begin{array}{l}\text { sificar estrutura } \\
\text { organizacional da CVRD }\end{array}$ \\
\hline
\end{tabular}

Fonte: Dados colhidos em: http://www.cvrd.com.br - acessado em 23/05/2004. Elaboração do autor.

\section{III.3.2.2 A Embraer - Empresa Brasileira de Aeronáutica S.A.}

- Fundada em 1969 a empresa realizou o primeiro vôo de um avião por ela produzido, o Ipanema, já em 1970.

- Em 1971 produzia um avião de treinamento, ataque e foto-reconhecimento, o Xavante, produzido de 1971 a 1982 sob licença da italiana Aermacchi. Produzira, até então, cerca de 182 aeronaves.

- Em 1972 passou a fornecer o modelo EMB 110 (Bandeirante) para a Força Aérea Brasileira.

- Em 1976 o Xingu levantou vôo, e em 1979 foi fundada a EAC, Embraer Aircraft Corporation.

- Em 1980 ocorreu o primeiro vôo de mais um modelo, o EMB 312, batizado como Tucano, e neste mesmo ano ocorreu a incorporação da Indústria Aeronáutica Neiva S.A.

- Em 1983 foi lançado o EMB 120 Brasília e foi fundada a EAI, Embraer Aviation International. Em 1985 voou pela primeira vez o modelo AMX.

- Em 1990 a empresa lançou o CBA 123 Vector, um Turboélice pressurizado, voltado para o mercado de aviação regional.

A Embraer foi privatizada, em 07/12/1994, em leilão na Bolsa de Valores de São Paulo, por R\$ 190 milhões ${ }^{127}$. O governo federal aceitou $100 \%$ do pagamento em "moedas podres", desde que fossem investidos prontamente R $\$ 30$ milhões. Foi o primeiro leilão a alcançar uma expressiva participação estrangeira. Além da Embraer, foram privatizadas quatro empresas coligadas: Neiva (aviões leves e agrícolas); EAC, extensão norte-americana da Embraer; EAE, extensão européia e a Embraer Divisão de Equipamentos. A Embraer foi adquirida pelo Grupo Bozano, Simonsen e pelos fundos Sistel e Previ (60\% em partes iguais). Em 1999, as empresas Dassault Aviation, Thales, EADS e Snecma, formaram um consórcio

${ }^{127}$ Biondi,1999, p. 39. 
para participar do negócio em 20\%. O governo brasileiro detém 1,45\%\% das ações, e o restante encontra-se pulverizado em ações ${ }^{128}$.

- Em 1995 ocorreu o primeiro vôo do ERJ 145 (Embraer Regional Jet). Em 1997 foi fundada a Embraer Austrália.

- Em 1998 ocorreu o primeiro vôo do ERJ 135 (37 passageiros) e em 1999 foram lançados os modelos EMB 145 AEW\&C (Airborne Early Warning \& Control), EMB 145 RS/AGS (Remote Sensing) e EMB 145 MP/ASW (P 99) (Maritime Patrol/ Anti-Submarine Warfare) e Super Tucano/ALX. Neste ano foi criada a Embraer Liebher Equipamentos do Brasil S.A. - ELEB.

- A partir de 2000 foram inaugurados o Centro de Realidade Virtual e a representação de Pequim. Em julho foram lançadas as ações da empresa na Bolsa de Valors de Nova York (NYSE) e na Bovespa. Neste ano, diversos lançamentos ocorreram, como o do ERJ 145 $\mathrm{XR}$, foram realizadas entregas importantes para a British Regional Airlines, para a Sichuan Airlines, marcando a entrada da empresa no mercado chinês. Iniciaram-se, ainda, as obras do Pólo Industrial de Gavião Peixoto e foi inaugurada a representação em Cingapura.

- Em 2001 passou a operar a Unidade de Eugênio de Melo, em S. José dos Campos. A empresa foi contratada para o programa de modernização dos F-5BR da FAB. Diversas entregas foram realizadas, para a Crossair, SA Airlink (África do Sul), para a FAB, e lançamentos foram realizados, como o primeiro vôo do Legacy, e o do EMBRAER 170, entre outros.

- Em fevereiro de 2002 foi realizado o primeiro vôo do EMBRAER 170, e em março a Embraer adquiriu as operações da Celsius Aerotech Inc. em Nashville, e em maio a Embraer entregou o $600^{\circ}$ Jato Regional para a Swiss Airlines.

Com um total de 12.940 funcionários trabalhando no Brasil e no exterior, em diversos países, tais como Estados Unidos, França, Austrália, China e Cingapura, a Embraer atua na construção de aviões executivos, com faturamento em 2003 da ordem de R $\$ 7,748$ bilhões ${ }^{129}$.

\footnotetext{
${ }^{128}$ Forbes Brasil, 06/06/2001.

${ }^{129}$ Carta Capital, 10/03/2004.
} 


\section{III.4 Empresas brasileiras frente ao movimento de fusões e aquisições}

\section{III.4.1 A Ambev - American Beverage}

A Ambev, a maior empresa de bebidas da América Latina, é também considerada a sétima maior empresa do setor de bebidas do mundo. Ela resulta da fusão da cervejaria Brahma com a Companhia Antarctica, ocorrida no ano de 1999, e de recente transação com a Interbrew (Bélgica) em 2004. A história da Ambev se mistura, portanto, com o histórico de desenvolvimento de duas grandes empresas brasileiras do ramo de bebidas (cervejas e refrigerantes).

\section{Breve histórico da Antarctica}

A Companhia Antarctica Paulista surgiu em São Paulo (1885), inicialmente fabricando apenas gelo e alguns gêneros alimentícios. Em menos de quatro anos estava produzindo cerveja.

Em 1904 a Companhia Antarctica Paulista adquiriu o controle acionário da Cervejaria Bavária, no bairro da Moóca, em São Paulo, e esta passou a ser a sua principal fábrica.

O Club Soda Antarctica chegou ao mercado em 1911, e a empresa inaugurou, em Ribeirão Preto (SP), sua primeira filial, que produziria gelo e cerveja. Em 1912 foi lançada a Soda Limonada. A partir de 1915 a Antarctica passou a fabricar as primeiras geladeiras a gelo, batizadas de Perfeitas, para utilização em estabelecimentos comerciais e residências. O gelo era fornecido pela companhia.

Em 1921 deu-se a produção e comercialização do Guaraná Champagne Antarctica, que se transformou no padrão da categoria e líder do segmento.

Em 1922 a Antarctica inaugurou filiais em Santos (SP), Ribeirão Preto e no Rio de Janeiro (RJ), além de agências nos principais centros consumidores do país. A companhia conservava áreas de lazer, à época, em São Paulo, como o Parque Antarctica, o Bosque Saúde, o Bosque Ipiranga, o Teatro Cassino e o Cinema Central.

Em 1940, no quadro da Segunda Guerra, foi suspensa a importação de bebidas, o que beneficiou o mercado nacional. Em 1941 a Antarctica passou a controlar a Companhia Adritica, do Paraná, cuja marca principal era a cerveja Original, produzida desde 1930. 
A Antarctica constituiu a Cerveja Polar (em 1945), e a Cervejaria Serramalte (1953). No ano de 1956 constituiu a Dubar S.A. - Indústria e Comércio de Bebidas.

A capacidade de produção de cervejas e refrigerantes da Antarctica alcançou 3,9 milhões de hectolitros em 1960. A Companhia Antarctica adquiriu, em 1961, o controle acionário da Cervejaria Bohemia, fundada em 1853 em Petrópolis (RJ). Em 1968 a Antarctica inaugurou fábricas em Manaus e em Minas Gerais.

A Antarctica adquiriu o controle total da Cervejaria Polar, em 1972, no Rio Grande do Sul, e da Companhia Baiana de Alimentos, com fábrica de cervejas em Camaçari (BA). Também adquiriu o controle da Cervejaria Pérola, de Caxias do Sul, e da Companhia Itacolomy de Cervejas (Pirapora, MG), em 1973. Além disso foram constituídas as filiais de Goiânia (GO), Montenegro (RS), Rio de Janeiro (RJ) e Viana (ES). A companhia construiu em Maués (AM), uma unidade de processamento de sementes de guaraná e criou uma fazenda para pesquisar e plantar guaranazeiros. Constituiu filial no Rio Grande do Sul, em 1975, e em Teresina (PI), em 1976. Em 1977 a Antarctica ampliou sua Maltaria em São Paulo e comprou área de 14,32 hectares, em Paulo de Frontim (PR), para pesquisar cevada cervejeira. Assumiu controle acionário da Serramalte em 1978 (Rio Grande do Sul).

Em 1979 a Antarctica passou a exportar para Europa, Estados Unidos e Ásia. No ano seguinte, sua produção atingiu 16,4 milhões de hectolitros/ano e finalizou a aquisição do controle da Cervejaria Serramalte, com suas fábricas de Getulio Vargas e Feliz (RS), e da Companhia Alterosa de Cervejas, em Vespasiano (MG).

A Antarctica inaugurou, em 1982, sua unidade de recebimento, armazenamento e beneficiamento de cevada cervejeira na cidade de Lapa (PR). Deu início à produção na filial de Teresina (PI), no ano seguinte. Em 1984 foi constituído o Grupo Antarctica, com sede em São Paulo e mais de 23 empresas controladas. Em 1985 foi iniciada a construção da fábrica da Antarctica em João Pessoa (PB). Em 1988 a Antarctica inaugurou, no Rio de Janeiro, uma fábrica de cervejas com capacidade de produção de 3,5 milhões de hectolitros/ano. Teve início a produção na fábrica de João Pessoa (PB). Em 1989 a empresa constituiu mais quatro unidades fabris: Jaguariúna (SP), Canoas (RS), Cuiabá (MT) e Natal (RN). Foram lançadas as versões diet dos seus refrigerantes.

Em 1991 foram inauguradas fábricas no Rio Grande do Norte e em Canoas (RS). A companhia adquiriu nova área, de 40,2 hectares, em Lapa (PR), para intensificar os trabalhos de pesquisa com cevada cervejeira nacional. Foi lançada a Kronenbier, primeira cerveja sem 
álcool do país. Em 1992, no centro de Tecnologia de Alimentos do Senai, em Vassouras (RJ), foi implantada a primeira cervejaria-escola do Brasil, uma iniciativa conjunta da Antarctica e da Brahma. Foi lançada a Antarctica Bock. A filial Jaguariúna foi inaugurada em 1993, ano de constituíção de filial também no Ceará. A fábrica da Antarctica no Rio Grande do Norte foi inaugurada em 1994. A partir de 1995, os produtos Antarctica passaram a ser fabricados em outras duas novas fábricas: São Luís (MA) e Cuiabá (MT). Em 1996 foi constituída a Budweiser Brasil Ltda, uma parceria entre a Antarctica e a Anheuser-Busch. Em 1997 foi constituída a Subsidiária Integral Antarctica U.S.A Inc, em Miami, para distribuir o Guaraná Antarctica nos EUA. No mesmo ano a Antarctica conquistou prêmios internacionais de melhor cerveja estrangeira em Miesenbach, Berlim, Dusseldorf e Baviera, e o Selo de Qualidade Monde Selection.

\section{Breve histórico da Brahma}

Em 1888 surgiu a cerveja Brahma, no Rio de Janeiro, produzida pela Manufatura de Cerveja Brahma Villiger \& Companhia.

Em 1894 ocorreu a associação entre a Brahma e a Cervejaria Georg Maschke \& Cia. A nova empresa importou equipamentos, patrocinou bares, restaurantes, clubes e artistas e aperfeiçoou a fabricação de seu produto.

A Cervejaria Bavária foi adquirida e a marca Franziskaner-Bäu foi registrada em 1899. Em seguida surgiu a Companhia Cervejaria Brahma Sociedade Anônima, resultante da fusão entre a Georg Maschke \& Cia Cervejaria Brahma e a Preiss Häussler \& Cia. Cervejaria Teutônia.

Em 1908, as principais marcas da Empresa eram: ABC, Guarany, Bock-Ale, Ypiranga, Crystal, Franziskaner-Bräu, Brahma-Bock, Pilsener, Teutonia e Brahma-Porter. Vinte anos mais tarde adquiriu a Companhia Guanabara, sediada em São Paulo, iniciando a produção da cerveja Brahma no território paulista, sendo que sua segunda unidade neste estado foi inaugurada em 1960, no município de Agudos.

Em 1968 a Brahma inaugurou uma Estação Experimental de Cevada, no Rio Grande do Sul, para testar novas variedades de cevada. Em 1970 ocorreu a associação entre a Brahma e a Fratelli Vita Indústria e Comércio S.A., iniciando a produção de três marcas: Sukita, Guaraná Fratelli e Gasosa Limão. No ano seguinte, a Brahma adquiriu a fábrica Astra S.A., e tornou-se líder na fabricação e distribuição de bebidas nas regiões Norte e Nordeste do país, 
expandindo sua presença no território nacional e no mercado, com filial da Brahma também em Curitiba através da incorporação da Cervejaria Atlântica.

Em 1980 a Brahma assumiu o controle acionário das Cervejarias Reunidas Skol Caracu S.A., fabricante da Skol desde 1967 (a Skol havia inovado ao lançar a cerveja em lata de folha de flandres). Em 1984 a Brahma firmou acordo com a PepsiCo Internacional para fabricar, comercializar e distribuir a Pepsi Cola no Brasil. Em 1985 a Brahma era a $7^{\text {a }}$ empresa de cerveja do mundo, conforme o jornal alemão Frankfurter Allgemeire Zeitung. Em 1987, além de inaugurar uma cervejaria piloto em seu laboratório no Rio de Janeiro, a companhia adquiriu a Fábrica de Refrigerantes Refinco. Em 1988 foi inaugurada a Cebrasp Companhia Cervejaria Brahma, em Jacareí (SP), e no ano seguinte ocorreu a aquisição acionária da Companhia Cervejaria Brahma pelo Grupo Garantia.

Em 1992, ocorreu a implantação da primeira cervejaria-escola do Brasil, uma parceria entre Antarctica e Brahma. Em 1993 iniciou-se a internacionalização da empresa, com o início da construção da primeira fábrica na Argentina. Em 1994 foi inaugurada filial da Brahma em Lages (SC) e em Luján (Argentina), e adquiriu a Companhia Anônima Cervecera Nacional (Venezuela). Em 1995 a Miller Brewing Company e a Brahma formaram joint venture para distribuir a Miller Genuine Draft no Brasil. Em 1996 foi inaugurada, no Rio de Janeiro, a maior e mais moderna fábrica de cervejas da América Latina, com capacidade para produzir 12 milhões de hectolitros. Também foram iniciadas as construções de mais duas unidades: Viamão (RS) e Aracaju (SE). A Fratelli Vita adquiriu a Marca Marathon e passou a produzir uma bebida isotônica. Os refrigerantes Brahma passaram a ser produzidos também na Argentina; e a cerveja Miller (produzida desde 1855 pela Cervejaria Miller, de Wisconsin) passou a ser fabricada e distribuída no Brasil pela Brahma. A Skol fechou contrato de licenciamento de marca com a cervejaria dinamarquesa Carlsberg (fundada em 1847). Em 1997 a Brahma adquiriu da Unilever a concessão para fabricar, comercializar e distribuir no Brasil o chá Lipton Ice Tea. Foram lançadas ações da Brahma na Bolsa de Nova York. A Carlsberg Beer iniciou sua participação no mercado nacional através da Skol-Caracu. A partir de 1998, iniciou as exportações para a Europa, ingressando no mercado estrangeiro pela França, aproveitando a Copa de Futebol. A Brahma inaugurou unidade fabril em Viamão (RS), ampliando seus canais com os países do Mercosul. 


\section{A AMBEV}

Em $1^{\circ}$ de julho de 1999 ocorreu o anúncio da fusão entre a Companhia Antarctica Paulista e a Companhia Cervejaria Brahma, criando a AmBev (American Beverage Company). A empresa surgiu como a terceira maior indústria cervejeira e a quinta maior produtora de bebidas do mundo. A Antarctica e a Anheuser-Busch anunciaram o fim de seu acordo no Brasil. Foi anunciada, ainda, a internacionalização do Guaraná Antarctica, em parceria com a PepsiCo.

Em 2000 a criação da AmBev foi aprovada pelo Cade. A Securities Exchange Comission (SEC) autorizou a listagem de ADRs da AmBev na Bolsa de Nova York. Os papéis foram lançados em setembro, quando foi anunciada a aquisição, em parceria com a Danone, da Salus, a segunda maior cervejaria e líder no setor de água mineral do Uruguai. Em novembro ocorreu a aquisição da Cerveceria y Malteria Paysand (Uruguai), produtora das marcas Nortea e Prinz. Conforme estabelecido pelo Cade, foram vendidas a marca Bavária e cinco fábricas: Ribeirão Preto, Getúlio Vargas, Camaçari, Cuiabá e Manaus, para a cervejaria canadense Molson.

Em 2001 o Guaraná Antarctica chegou ao mercado europeu, engarrafado e distribuído pela Pepsi. No Paraguai a Ambev comprou o parque industrial da Cervecería Internacional. Em 2002 com a aliança criada com a Quilmes Industrial S.A. (Quinsa), a Ambev adquiriu 40,9\% de participação na Quinsa - maior cervejaria da Argentina, e também da Bolívia, Paraguai e Uruguai - integrou as operações na América do Sul e criou a terceira maior operação comercial de bebidas do mundo, com produção anual de 10 bilhões de litros. A participação da AmBev na Quinsa é de 40,9\%. Ainda foi anunciada parceria com a CabCorp. - principal engarrafadora Pepsi da América Central -, para atuar no mercado de cervejas daquela região a partir da construção de cervejaria na Guatemala. A AmBev passou a produzir o Gatorade, marca adquirida internacionalmente pela PepsiCo.

Em 2003 o órgão regulador da concorrência argentino aprovou a aliança com a Quilmes. Foram integradas as operações das duas empresas na Argentina, no Uruguai e no Paraguai e a AmBev iniciou a construção de fábrica no Peru, adquiriu os ativos da Embotelladora Rivera, assumindo a franquia da PepsiCo, no norte do Peru e em Lima, e duas unidades industriais, com capacidade de produção estimada de 630 milhões de litros anuais. Iniciaram-se as operações na Guatemala; foi anunciada a aquisição da Cerveceria SurAmericana, no Equador, segunda maior cervejaria do país. 
Em 2004 a Ambev associou-se com a cervejaria belga Interbrew, em uma operação avaliada em US\$ 11,3 bilhões, considerada a maior operação realizada no país até então, um valor bastante superior ao alcançado pela venda da Companhia Vale do Rio Doce e das empresas do sistema Telebrás, se consideradas separadamente ${ }^{130}$. Se consideradas apenas em relação ao "valor" das empresas estatais, a comparação com a transação entre Ambev e Interbrew talvez seja uma evidência do baixíssimo preço alcançado pelas empresas estatais. Por outro lado, se consideradas outras características - a CVRD era proprietária de áreas florestadas, de porções consideráveis do solo e do subsolo nacional - ou, ainda, o "valor" estratégico de algumas dessas empresas, a desvalorização dessas instituições foi total.

No caso da aquisição da Ambev pela Interbrew, gerando a InBev, que passa a deter o controle acionário da Ambev, a sede da nova empresa localiza-se na Bélgica, enquanto as operações da Ambev são realizadas no Brasil. Uma vantagem para a Ambev, que reduzirá seus custos financeiros, pois não estará mais submetida ao "risco-Brasil""131.

\section{III.4.2 A VOTORANTIM}

O Grupo Votorantim, um dos maiores conglomerados industriais da América Latina, participou de dezoito operações de fusões e aquisições no período 1997-2003, e foi relacionado pela KPMG como o quinto colocado entre as empresas que mais participaram destas transações no Brasil.

O Grupo surgiu de uma pequena indústria têxtil, em São Paulo, em 1918, quando Antonio Pereira Inácio arrematou a Fiação e Tecelagem no leilão da massa falida do Banco União, em Votorantim, distrito da cidade de Sorocaba. O empreendimento foi denominado Sociedade Anônima Fábrica de Votorantim. Rapidamente a Sociedade Anônima Fábrica de Votorantim posicionou-se como uma das maiores empresas do mercado de tecelagem de S. Paulo, com 3.400 funcionários, e em 1925 adquiriu a Usina Hidrelétrica Boa Vista, em Sarutaiá (SP).

\footnotetext{
${ }^{130}$ A Telesp foi adquirida pela por cerca de US\$ 4,96 bilhões, a Tele Norte Leste por US\$ 2,94 bilhões; a Tele Centro Sul por US\$ 1,77 bilhão; a CSN foi vendida por US\$1,49 bilhão, e a Embraer por US\$ 190 milhões (Biondi, 1999, p. 39). Para os valores das outras empresas do Sistema Telebrás, consultar Tabela III.15.

${ }^{131}$ O Estado de S. Paulo, 23/10/2004.
} 
Em 1933 teve início a construção da Fábrica de Cimento Santa Helena, que originou a Votorantim Cimentos. Em 1935, adquiriu a Tubize, que resultaria, dois anos depois, na Nitroquímica.

Foi inaugurada, em 1941, a Fábrica de Cimento Poty, segunda do grupo e maior da região nordeste. No ano seguinte, ocorreu a aquisição da, Indústria Brasileira de Artefatos Refratários (IBAR). Em 1944, entrou no ramo metalúrgico, através da Metalúrgica Atlas. Em 1948, o grupo entrou no ramo de papel transparente, com a inauguração da Votocel, em Votorantim. Em 1950, ocorreu a aquisição da Fábrica de Papel Pedras Brancas, em Guaíba (RS), e fundação da Cia. de Cimento Portland Rio Branco.

Em 1951 ocorreu a incorporação da Empresa de Eletricidade de Avaré à Cia. de Luz e Força Santa Cruz. Em 1952 foi inaugurado o primeiro forno de cimento branco do Brasil. Em 1953 começou a construir a Usina Hidrelétrica da Cachoeira da Fumaça, e iniciaram-se as atividades da Cia. de Cimento Portland Rio Branco (Paraná). Inauguração da CBA (Companhia Brasileira de Alumínio), em 1955. No ano seguinte o Grupo entrou no setor de açúcar, com a aquisição da Usina São José, em PE. Em 1957 adquiriu o controle da Cia. Brasileira de Metais (CBM).

Em 1960, ampliaram-se as atividades no ramo de papel e celulose, com a fábrica de Pedras Brancas, em Guaíba (RS). Neste ano, com 46 empresas em 12 Estados, o grupo é o maior conglomerado privado nacional da indústria de base. Em 1961 iniciaram-se as operações da Cia. Agroindustrial Igarassú. Em 1969 iniciaram-se as operações da Cia. Mineira de Metais.

Em 1972, iniciou a construção da CNT - Cia. Níquel Tocantins. Em 1977 o Grupo assumiu o controle acionário da Cia. Portland Itaú e a participação do Grupo no mercado nacional de cimento passou de $25 \%$ para $37 \%$.

A aquisição da Cia. de Cimento Sta. Rita ocorreu em 1986. Dois anos depois, o Grupo Votorantim comprou a Celpav, sua primeira fábrica de papel e celulose. Em 1989 apareceu a Citrovita, em Catanduva (SP), primeira fábrica de suco de laranja concentrado do Grupo Votorantim.

Em 1990 o Grupo detinha 96 empresas. Foi criada a Nordesclor. Em 1992 foi criada a Votorantim Celulose e Papel, integrando as unidades de papel e celulose do Grupo às unidades da recém-adquirida Papel Simão. Criação da Votorantim Internacional. Em 1995 foi 
criada a Votorantim Corretora. Em 1996 foi inaugurada a BV Financeira. Em 1997 foi criada a VBC Energia, em parceria com o Bradespar e o Grupo Camargo Correia.

Em 2000, a VCP foi listada na Bolsa de Valores de New York. A aquisição da St. Marys Cemente, no Canadá, em 2001, marcou o início da internacionalização do Grupo Votorantim. No mesmo ano, houve a aquisição de $28 \%$ do capital votante da Aracruz Celulose. A S. A. Indústrias Votorantim passou a se chamar Votorantim Participações, controladora dos principais negócios do Grupo. A VPAR passou a abrigar todos os ativos empresariais do Grupo. A aquisição da Paraibuna de Metais, deu-se em 2002, e posicionou o Grupo Votorantim entre os 5 maiores fabricantes de zinco do mundo. Aquisição da Engemix colocou a Votorantim na liderança no mercado brasileiro, com $20 \%$ de participação no mercado de concreto. Inauguração da Allelyx, estimulando a criação de empresas na área de biotecnologia. Aquisição da Suvannee Cemente Company, na Flórida. Aquisição da Optiglobe, que inseriu a Votorantim no mercado de serviços especializados no setor de tecnologia da informação.

A Votorantim era formada, em 1999, pelas empresas: VCP (celulose/papel); Citrovita (agroindústria); Cemento Itaú Argentina, Cim. e Argamassas Votoran, Cia. Cimento Portland Itaú, Votorantim Cimentos, Cimento Rio Branco (todas relacionadas ao setor de cimento); Luz e Força Santa Cruz, Serra da Mesa (VBC), Votorantim Energia (relacionadas ao setor elétrico), Banco Votorantim (financeiro); Alunorte (metalurgia); CBA (alumínio); CMM

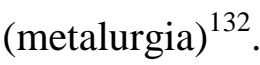

\section{III.4.3 A CONSTRUTORA NORBERTO ODEBRECHT}

A Construtora Norberto Odebrecht, fundada em 1944, atua nas áreas de Engenharia e Construção e Química e Petroquímica, além de participar nos setores de Infra-estrutura e Serviços Públicos. A Organização está presente no setor Químico e Petroquímico há mais de 20 anos. Possui mais de 28 mil integrantes em países da América do Sul, América do Norte, África e Europa. Atua em países como Portugal, Equador, Venezuela, Colômbia, México, Estados Unidos, Angola, Argentina, Uruguai, Paraguai.

\footnotetext{
${ }^{132}$ América Economia, 27/07/2000.
} 
Norberto Odebrecht vem de uma tradição de família, na área de engenharia civil e de infra-estrutura, por influência do avô, imigrante alemão, que atuou no sul e com o pai, empresário que atuou em Recife e posteriormente em Salvador.

Em 1919, Emílio Odebrecht fundou sua primeira empresa, a construtora Isaac Gondim e Odebrecht Ltda, alterando para Emílio Odebrecht \& Cia., em 1923, e transferindo-se para a cidade de Salvador, três anos depois. Com a crise no setor, devido a II Guerra Mundial, Norberto Odebrecht assumiu a empresa.

Em 1944, na Bahia, Norberto Odebrecht criou sua própria empresa, e no ano seguinte surgiu a Construtora Norberto Odebrecht, embrião da Organização Odebrecht, no ramo de engenharia e construção. Nos primeiros anos, a empresa restringiu-se a Salvador e ao interior da Bahia. Em 1953 a empresa construiu o oleoduto Catu-Candeias (BA), iniciando suas atividades juntos a Petrobrás. Nos anos 60 a Construtora se expandiu para o Nordeste, aproveitando o desenvolvimento incentivado pela Sudene, construindo em Pernambuco parques industriais, barragens e ponte na Bahia. Também iniciou obras nas regiões sudeste e sul do país.

Na década de 1970, a empresa voltou-se para a realização de obras de grande porte como metrôs, usinas nucleares, emissários submarinos, aeroportos e grandes pontes, além do campus da Universidade do Estado do Rio de Janeiro (RJ) e do edifício-sede da Petrobras (RJ). No final dos anos 70, iniciava-se a atuação internacional da Odebrecht, com a construção de hidrelétrica no Peru, e sistema hidrelétrico no Chile. Expandiu a sua atuação para países africanos, europeus e outros países da América do Sul. Em 1979, a Odebrecht diversificou suas atividades, ao adquirir participação acionária na CPC - Companhia Petroquímica de Camaçari (BA) e criou a OPL - Odebrecht Perfurações Ltda., para a perfuração em poços de petróleo já prospectados.

Em 1980, a Odebrecht adquiriu parte do controle acionário da CBPO - Companhia Brasileira de Projetos e Obras. No ano seguinte, criou a holding Odebrecht S.A., e os negócios petroquímicos foram ampliados, através de aquisições de participações acionárias na Salgema, Poliolefinas S.A., PPH e Unipar.

Os anos 90, sobretudo a partir da segunda metade da década, a empresa ampliou sua atuação em escala mundial, começando nos Estados Unidos e Inglaterra, com a presença consolidada na América Latina e na África. No programa brasileiro de privatizações, adquiriu o controle de empresas químicas e petroquímicas, como o controle de 62,9\% da Poliolefinas. 
Passou a atuar em empreendimentos nas áreas de Infra-Estrutura e Serviços Públicos e Celulose.

Em 2001, associada com o Grupo Mariani, a Odebrecht adquiriu o controle da Petroquímica do Nordeste - Copene ${ }^{133}$, a central de matérias-primas do Pólo de Camaçari, na Bahia, e assim aumentou a sua participação no setor químico e petroquímico. $\mathrm{O}$ resultado deste processo foi a Braskem, a maior empresa petroquímica da América Latina, criada em 2002, com unidades em Alagoas, Bahia, Rio Grande do Sul e São Paulo.

Atualmente a empresa lidera a produção de termoplásticos na América do Sul e de cloro-soda no Brasil e, associada com a Bento Pedroso Construções (BPC), ela participa de concessões de serviços públicos em Portugal. No Brasil, também participa em sociedade na concessionária Águas de Limeira S.A., através da OSI - Odebrecht Serviços de Infra-estrutura S.A., constituída em 1997.

\section{III.4.4 O GRUPO GERDAU}

Com faturamento total de $\mathrm{R} \$ 15,8$ bilhões, o Grupo Gerdau atua na área de siderurgia e possui operações externas no Uruguai, Chile, Argentina, Estados Unidos e Canadá, com um total de 20 mil funcionários, sendo 8 mil no exterior.

Em 1901, João Gerdau e Hugo Gerdau (filho) criaram a Fábrica de Pregos Pontas de Paris, em Porto Alegre (RS). Em 1907 os negócios foram divididos em dois ramos independentes: fábrica de pregos e fábrica de móveis. Quarenta anos depois, Curt Johanpeter (genro de Hugo Gerdau), assumiu a direção da empresa, expandindo os negócios para o setor siderúrgico, com a instalação da Usina Riograndense, em Porto Alegre (RS). Em 1957 iniciaram-se as operações da Usina II da Siderúrgica Riograndense, em Sapucaia do Sul (RS).

Na década de 1960, a empresa ampliou o segmento de pregos e inaugurou a Fábrica de Arames S. Judas Tadeu, em S. Paulo (SP). Em 1969 deu início à produção de aço, em Pernambuco, através da Siderúrgica Açonorte.

Em 1971, a empresa cresceu por aquisição e diversificação, com a compra do projeto da Cia. Siderúrgica da Guanabara, Cosigua (RJ), em associação com o Grupo Alemão

\footnotetext{
${ }^{133}$ No programa de desestatização brasileiro a Copene adquiriu 48,0\% da Acrinor; 20,5\% da Coperbo e 50,0\% da Salgema.
} 
Thyssen ATH. Foi criada a Comercial Gerdau, distribuidora de aços longos e planos, e o Grupo também assumiu o controle da Siderúrgica Guairá, pioneira na produção de aço no Paraná. Neste ano também foi constituída a Seiva S.A., em Porto Alegre, voltada para atividades de reflorestamento.

O ano de 1980 assinalou o início da internacionalização do Grupo com a Siderúrgica Laisa, no Uruguai. No ano seguinte, começou a construção de duas novas siderúrgicas: a Cearense (CE) e a usina de Araucária (PR). Em 1988, aumentou a produção de pregos e, em seguida, iniciou a produção de pregos na usina Barão de Cocais, em Minas Gerais, quando o Grupo adquiriu a siderúrgica em leilão de privatização. Em 1989, incorporou a siderúrgica canadense Courtice Steel e venceu a privatização da Usiba, na Bahia.

Em 1992, através da Siderúrgica AZA entrou no Chile e, no mesmo ano, adquiriu a Siderúrgica Aços Finos Piratini, ingressando no ramo de aços especiais. Em 1994, comprou a siderúrgica Pains, em Minas Gerais, fundou o Banco Gerdau. No Canadá, em 1995, comprou a MRM Steel. Em 1997, a Gerdau associou-se à Açominas, junto com a NatSteel e o Clube de Empregados da Empresa. No mesmo ano, entrou no mercado da Argentina instalando a laminadora de aços longos Sipsa e, no ano seguinte, se associou com a laminadora Sipar Aceros S.A. Em 1999, inaugurou nova planta no Chile e adquiriu a AmeriSteel Corporation (segunda produtora de vergalhões nos EUA).

Em 2000, a Gerdau associou-se com a Monteferro, para fabricar guias para elevadores (a maior da América Latina) e assumiu o controle acionário da Açominas. Em 2002, assumiu a Siderúrgica Birmingham Southheast, quinta usina da empresa nos Estados Unidos e, através da fusão com a norte-americana Co-Steel, formou a Gerdau Ameristeel Corporation com o valor de mais meio bilhão de dólares. No mesmo ano comprou a participação da NatSteel na Açominas. Em 2003, os ativos da Gerdau e da Açominas no país foram integrados na Gerdau Açominas, a empresa assumiu sua segunda usina produtora de ferro-gusa no Maranhão e adquiriu empresa de minério de ferro, em Minas Gerais, possibilitando a extração própria da matéria-prima.

A Gerdau tem operações na Bolsa de New York, desde a década de 1990, e mais recentemente opera no Latibex da Bolsa de Madri.

A Gerdau encontra-se formada pelas seguintes empresas: Gerdau Laisa, Gerdau AZA - Chile, Gerdau MRM Steel Inc., Gerdau Courtice Steel Inc., Sipsa, Sipar Aceros, Ameristeel 
Corp., Açominas, todas relacionadas ao setor de aço, além da Armafer Serviços de Construção, setor de serviços e Seiva, setor florestal ${ }^{134}$.

\section{III.4.5 A WEG}

A WEG foi fundada em 1961, por Werner Ricardo Voigt, Eggon João da Silva e Geraldo Werninghaus, em Santa Catarina, para fabricar motores elétricos, e hoje é considerada uma das multinacionais brasileiras.

A empresa cresceu rapidamente, e a produção passou de 146 motores em 1961, para 4.085 unidades em 1962. No início a WEG produzia apenas motores elétricos, mas na década de 80 havia expandido sua produção com geradores, componentes eletroeletrônicos, produtos para automação industrial, transformadores de força e distribuição, tintas líquidas e em pó e vernizes eletroisolantes. Assim a WEG tornou-se a maior indústria de motores elétricos da América Latina, com presença em mais de 50 países.

A WEG possui cinco parques fabris no Brasil, onde controla todas as etapas da produção, desde a fundição e a estamparia até a esmaltação e a embalagem. Em Santa Catarina se concentra a maior parte da produção, mas a partir de 2000, com a aquisição de fábricas no exterior, a WEG torna-se multinacional brasileira.

$\mathrm{Na}$ atualidade a WEG é a maior indústria de motores elétricos da América Latina, conta com 11.600 funcionários e faturou $\mathrm{R} \$ 2$ bilhões em $2003^{135}$.

Apesar deste capítulo tratar especificamente do Brasil, parece interessante observar a tabela III.17, das 500 maiores empresas da América Latina. Ela aponta o grupo de empresas cuja participação sofreu maiores perdas e também revela o grupo daquelas empresas que aumentaram a sua participação, respectivamente o grupo das empresas estatais, e o grupo das empresas estrangeiras. No âmbito das 500 maiores empresas, a participação das empresas nacionais não apresentou alteração. Ao menos no âmbito considerado das 500 maiores empresas, a participação de empresas nacionais não apontou qualquer modificação. Entretanto, deve ser observado que esse ranking considera como "nacionais" empresas como Carrefour (14 lugar em 1999), Shell (26 lugar em 1999), Nestlé (50 lugar em 1999), Gessy

\footnotetext{
${ }^{134}$ América Economia, 27/07/2000.

135 http://www.weg.com.br/,11/06/2004; http://www.petma.ufsc.br/hp/weg.asp 11/06/2004; e Carta Capital, $10 / 03 / 2004$
} 


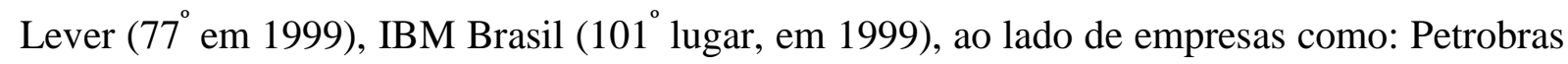
( $3^{\circ}$ lugar), Eletrobrás (11 lugar), Petrobras Distribuidora (13 lugar), Companhia Vale do Rio Doce (22 lugar), Odebrecht ( $35^{\circ}$ lugar), Varig (51 lugar), Embraer $\left(66^{\circ}\right)$, Gerdau $\left(67^{\circ}\right)$, Sabesp $\left(72^{\circ}\right)$, entre outras.

\section{Tabela III.17}

Participação das 500 maiores empresas latino-americanas - 1989-1999

\begin{tabular}{|c|c|c|c|c|}
\hline \multicolumn{5}{|c|}{ Empresas Estatais } \\
\hline \multicolumn{2}{|c|}{ No. de Empresas Estatais } & $\begin{array}{c}\text { Total das Vendas } \\
\text { (US\$ milhões) }\end{array}$ & $\begin{array}{c}\text { Total vendas das } 500 \\
\text { maiores (US\$ milhões) }\end{array}$ & $\begin{array}{c}\text { Participação estatal } \\
\text { vendas das } 500\end{array}$ \\
\hline 1989 & 116 & 145.637 & 383.718 & $38 \%$ \\
\hline 1999 & 35 & 137.986 & 640.891 & $22 \%$ \\
\hline \multicolumn{5}{|c|}{ Empresas Nacionais } \\
\hline \multicolumn{2}{|c|}{ No. de Empresas Nacionais } & $\begin{array}{c}\text { Total das Vendas } \\
\text { (US\$ milhões) }\end{array}$ & $\begin{array}{l}\text { Total vendas das } 500 \\
\text { maiores (US\$ milhões) }\end{array}$ & $\begin{array}{c}\text { Participação estatal } \\
\text { vendas das } 500\end{array}$ \\
\hline 1989 & 267 & 148.589 & 383.718 & $39 \%$ \\
\hline 1999 & 267 & 260.161 & 640.891 & $41 \%$ \\
\hline \multicolumn{5}{|c|}{ Empresas Estrangeiras } \\
\hline \multicolumn{2}{|c|}{ No. de Empresas Estrangeiras } & $\begin{array}{c}\text { Total das Vendas } \\
\text { (US\$ milhões) }\end{array}$ & $\begin{array}{l}\text { Total vendas das } 500 \\
\text { maiores (US\$ milhões) }\end{array}$ & $\begin{array}{c}\text { Participação estatal } \\
\text { vendas das } 500\end{array}$ \\
\hline 1989 & 117 & 89.492 & 383.718 & $23 \%$ \\
\hline 1999 & 198 & 242.745 & 640.891 & $38 \%$ \\
\hline
\end{tabular}

Fonte: América Economia, 23/07/2004.

\section{III.5 Transações no setor financeiro}

O setor bancário, no Brasil, é um setor que apresenta forte concentração. As maiores instituições no Brasil são estatais (caso do Banco do Brasil, Caixa Econômica Federal), ou de capital privado nacional (caso do Bradesco, Itaú, Unibanco, etc.).

Entretanto, é crescente a participação de instituições financeiras de capital estrangeiro no mercado brasileiro, principalmente através da aquisição de bancos estatais (Banespa/Santander), aquisição de bancos privados (Bamerindus/HSBC) ou através de operações de fusão (ABN Amro/Real), entre outras transações (por exemplo, ExcelEconômico, adquirido pelo BBV, que terminou sendo comprado pelo Bradesco).

Portanto, os negócios mais representativos da entrada do capital estrangeiro no setor financeiro foram: a compra do Banco Bamerindus pelo britânico HSBC, em março de 1997, por R\$ 930 milhões; do Banco Real pelo holandês ABN Amro Bank, em junho de 1998, por 
R\$ 2 bilhões ${ }^{136}$; e do Banco do Estado de São Paulo - Banespa, pelo espanhol Banco Santander Central Hispano - BSCH, por anunciados R\$ 7,05 bilhões, em 20/11/2000 ${ }^{137}$. Tais bancos não adquiriram apenas simples agências bancárias, imóveis ou ativos de milhares de clientes, mas também estruturas localizadas espacialmente, em uma estratégia de ocupar fatias de mercado altamente competitivas e estabelecidas. Ou seja, adquiriram produtos "prontos e acabados", entraram no mercado nacional em uma boa posição, com presença em todo o território e clientela estabelecida. À época da aquisição, o BSCH assumiu o 3o. lugar no ranking bancário privado do país, ultrapassando o Unibanco. $\mathrm{O} \mathrm{BSCH}$, com a aquisição do Banespa, adquiriu ativos da ordem de R\$ 28,9 bilhões, 572 agências e 771 postos de atendimento $^{138}$. Foi o valor mais alto jamais pago a um banco público, porém, à época do negócio, ocorreram denúncias de que o preço mínimo estipulado pelo governo federal para a venda era inferior a seu real valor. O preço mínimo estipulado era de $\mathrm{R} \$ 1,85$ bilhões, subavaliado em pelo menos $\mathrm{R} \$ 5$ bilhões.

Algumas das operações realizadas a partir da abertura ao capital estrangeiro no setor financeiro encontram-se relacionadas na tabela III.18, assim como algumas das operações de privatização encontram-se listadas na tabela III.19.

Tabela III.18

\section{FUSÕES E AQUISIÇÕES BANCÁRIAS}

\begin{tabular}{|l|l|}
\hline \multicolumn{1}{|c|}{ Data } & \multicolumn{1}{c|}{ TRANSAÇÃO } \\
\hline Mai/95 & Itaú e Banks Trust formaram a joint venture IBT \\
\hline Maio/96 & Deutsche adquiriu o banco Grande Rio \\
\hline Jun/96 & Fusão entre os bancos Fonte e Cindam \\
\hline Dez/96 & Banco Gdida (argentino) compra parte do BCN no BCN - Bordays \\
\hline Mar/97 & Grupo Roberto Marinho vende sua participação no banco ABC Brasil \\
\hline Abr/97 & Morgan Grenfell compra Banco Irmãos Guimarães \\
\hline Set/97 & Banco SLR e American Express forman a joint venture Banco Interamerican Express \\
\hline Out/97 & Banco Stok funde-se com a corretora Máxima \\
\hline Nov/97 & Banco Graphus é comprado pelo Robert Fleming \\
\hline Nov/97 & Pactual compra Banco Sistema \\
\hline Jan/98 & Nations Bank compra 40\% do Brascan \\
\hline Jun/98 & Crédit Suisse First Boston compra o Garantia \\
\hline Out/98 & Bradesco assume operações do Continental \\
\hline Jan/99 & Chase Manhattan absorve operações do Patrimônio \\
\hline Mai/99 & Banco português Bonif compra 51\% do Primus \\
\hline Jan/99 & Bank of New York assume controle do Credibanco \\
\hline Jan/00 & BBA e Icatu fundem área de administração de ativos \\
\hline
\end{tabular}

\footnotetext{
${ }^{136}$ Folha de S. Paulo, 15/10/2000.

${ }^{137}$ Folha de S. Paulo, 21/11/2000.

${ }^{138}$ Folha de S. Paulo, 21/11/2000.
} 


\begin{tabular}{|l|l|}
\hline Fev/00 & Unibanco compra Credibanco \\
\hline Mar/00 & Santander compra Meridional \\
\hline Jul/00 & Unibanco compra Bandeirantes \\
\hline Set/00 & Bradesco compra Boavista \\
\hline
\end{tabular}

Fonte: Trevisan, 21/09/00.

\section{Tabela III.19:}

OUTROS BANCOS PRIVATIZADOS (VALORES EM R\$)

\begin{tabular}{|l|c|c|c|c|c|}
\hline Instituição & Preço mínimo & Preço de venda & $\begin{array}{c}\text { Ágio } \\
(\%)\end{array}$ & Data do Leilão & Comprador \\
\hline Meridional & 172,90 & 265,60 & 53,61 & $04 / 12 / 97$ & Bozano Simonsen \\
\hline Bemge & 314,14 & 583,00 & 85,56 & $14 / 09 / 98$ & Itaú \\
\hline Bandepe & 183,00 & 183,00 & 0,00 & $17 / 11 / 98$ & ABN Amro \\
\hline Credreal & 121,30 & 121,30 & 0,00 & $07 / 08 / 97$ & BCN \\
\hline Banerj & 310,00 & 311,10 & 0,35 & $26 / 06 / 97$ & Itaú \\
\hline Baneb & 251,90 & 260,00 & 3,22 & $22 / 09 / 99$ & Bradesco \\
\hline
\end{tabular}

Fonte: Banco Central e BNDES

Conforme Paula (2003), as estratégias dos bancos e instituições financeiras estrangeiras no Brasil, no decorrer das décadas de 1970 e 1980, restringiam-se a "interesses minoritários em bancos de investimentos e empresas de leasing” (p. 170).

A Constituição de 1988 proibia o aumento da participação estrangeira nas instituições financeiras e a abertura de novos bancos estrangeiros no país. O aumento dessa participação foi possível com a utilização de dispositivo explicitado pela própria Constituição, previsto no artigo 52 da Lei sobre as disposições transitórias. Este definia que as restrições não seriam "aplicáveis às autorizações outorgadas em virtude de acordos internacionais, a título de reciprocidade, ou por decisões cujo objeto seja favorecer os interesses do governo brasileiro" (Paula, 2003, p. 170).

Com a crise bancária de 1995, no Brasil, como reflexo da crise mexicana, e a aplicação do mencionado dispositivo legal, o governo brasileiro autorizou a participação de bancos estrangeiros na aquisição de estabelecimentos bancários deficitários, pregando a tese que o setor bancário nacional seria fortalecido (Paula, p. 170).

O PROER ${ }^{139}$, em 1995, conforme Cano (1999) significou gastos próximos a $5 \%$ do Pib brasileiro.(p. 239), mas tais cifras podem ser bem maiores (vide nota 138). A Comissão Parlamentar de Inquérito ${ }^{140}$ encarregada de investigar a ajuda federal aos bancos, estimou o custo do auxílio em R \$ 37,7 bilhões, sendo R\$ 22,9 bilhões do PROER, R\$ 1,9 bilhão do

139 PROER, sigla do "Programa de Estímulo à Reestruturação e ao Fortalecimento do Sistema Financeiro Nacional". Conforme Cano (2000) este programa, viabilizado no governo do PSDB de Fernando Henrique Cardoso, significou gastos próximos a 5\% do PIB brasileiro (p. 239).

${ }^{140}$ Mais conhecida como "CPI dos bancos". 
Fundo Garantidor de Crédito e R\$ 12,9 bilhões de reservas bancárias (FSP, 25/11/99). Em princípio, o socorro aos bancos nacionais, através do PROER, "necessário" conforme o governo, por causa do risco de quebra do sistema, redundou em um grande escândalo ${ }^{141}$.

Dessa forma houve aumento da participação dos bancos estrangeiros "no total de ativos da banca do país de 8,4\% em 1995 para 27,4\% em 2000" (Paula, p. 170). Com isso explica-se, em linhas gerais, a entrada de grandes bancos europeus no Brasil, principalmente dos espanhóis BSCH e BBV, além do britânico HSBC e do holandês ABN Amro Bank.

Os bancos espanhóis lançaram-se a uma estratégia de fusões e aquisições sem precedentes na Espanha, diante da iminência “do processo de união econômica e monetária como preparação para a entrada em vigor da moeda única, o Euro" (Calderón e Casilda, p. 73).

As fusões e aquisições bancárias na Espanha intensificaram-se desde o final dos anos 1980, quando o Banco de Bilbao fundiu-se com o Banco de Vizcaya, que resultou no Banco Bilbao Vizcaya - BBV. Em 1991 ocorreu a fusão dos Bancos Central e Banco Hispano, formando o Banco Central Hispano - BCH. No mesmo ano, constituiu-se a Corporação Bancária de Espanha (Argentaria) que congregava "todo o sistema de bancos públicos". A partir de 1994, o Banco Santander passou a controlar o Banco Espanhol de Crédito, além de ocorrer fusão entre o Banco Exterior de Espanha, a Caixa Postal e o Banco Hipotecario com a Argentaria. (Calderón e Casilda, p. 74).

Em 15 de janeiro de 1999, fundiram-se Santander e BCH, constituindo o Banco Santander Central Hispano - BSCH em "uma das maiores entidades européias," e BBV e Argentaria criaram o segundo maior banco espanhol, o Banco Bilbao Vizcaya Argentaria BBVA. Ao final de 1999, o BSCH e o BBVA possuíam, respectivamente, $37 \%$ e $30 \%$ dos créditos e depósitos do mercado, constituindo-se nos dois maiores bancos espanhóis. Além do que, a concentração dos bancos na Espanha resultou na maior de toda a Europa. A partir de então, dado o tamanho dessas instituições, foi possível iniciar-se uma estratégia de

\footnotetext{
141 "Quanto custou, realmente, o Programa de Estímulo à Reestruturação e ao Fortalecimento do Sistema Financeiro Nacional é ainda um mistério. O governo Fernando Henrique Cardoso aponta, segundo a imprensa, um custo deR \$20,3 bilhões. Já a Comissão Parlamentar de Inquérito dos Bancos do Senado chegou a um custo muito maior: R \$ 43,3 bilhões. Os economistas da Cepal (Comissão Econômica das Nações Unidas para a América Latina), Pedro Sainz e Alfredo Calcagno, por sua vez, afirmam que foram torrados R \$111,3 bilhões em ajuda a bancos quebrados ou em dificuldades, mas aí estão todos os bancos, não apenas os incluídos no Proer" (Bortoni e Moura, 2002, p. 69).
} 
internacionalização em busca dos mercados de "Portugal, França, Itália, Marrocos e muito especialmente América Latina" (Idem, p. 74 e 85).

Com o mesmo propósito, foram estabelecidas alianças e aquisições de participações minoritárias em outras entidades, como por exemplo, a aquisição pelo BBV de " $10 \%$ da Banca Nazionale del Lavoro - BNL, 3,8\% do banco francês Crédit Lyonnais e uma sociedade de valores em Portugal (Midas)", além de negócios realizados pelo Banco Santander, etc.. (Idem, p. 74).

Ao mesmo tempo, durante os anos 1990, viabiliza-se uma estratégia de investimentos ousada por parte dos capitais espanhóis, investindo maciçamente na América Latina, nos setores relacionados a "serviços, principalmente telecomunicações, comércio varejista, energia e finanças"; no caso, prefere-se adquirir ativos existentes, primeiramente utilizando-se “dos amplos programas de privatizações e posteriormente mediante a aquisição de firmas privadas locais", com significativo papel dos bancos espanhóis, através de financiamentos e associações com as empresas espanholas em empreendimentos na América Latina (Calderón e Casilda, 2000, p. 72).

De acordo com Calderón e Casilda (2000), o lançamento do nova moeda, o Euro, "acelerou as trocas e reduziu os cronogramas, modificando as estratégias de expansão dos principais bancos europeus". Esperava-se um processo intenso de fusões "entre bancos de mesma nacionalidade", pois os negócios transfronteiriços trazem dificuldades "pelas diferenças de idioma, cultura e sistemas regulatorios e impositivos” (p. 75).

Por esse motivo, esperavam-se fusões como aquelas ocorridas na Espanha, entre o Banco Santander e o BCH e entre o BBV e Argentaria, também na França, na Itália e na Alemanha, com os bancos desses países garantindo a posição em seus países e, posteriormente, disputando o mercado da União Européia e outros fora dela. A ressaltar o fato de que, tanto na Espanha como nos demais países da União Européia, os bancos estrangeiros não alcançam participações expressivas (Calderón y Casilda, p. 75).

Assim, havia no mercado da América Latina boas oportunidades de investimentos, em um momento de abertura e desregulação, e também ótimos preços, ao contrário do cenário europeu onde "as possibilidades de aquisições eram escassas e de alto preço" (Calderón y Casilda, p. 75), e os bancos espanhóis passaram a investir na América Latina, onde conseguiram participação expressiva, conforme nota-se no Mapa III.2. 


\section{Mapa III.2}

Banco Santander Central Hispano e Banco Bilbao Viscaya: Presença na América Latina - 1999a

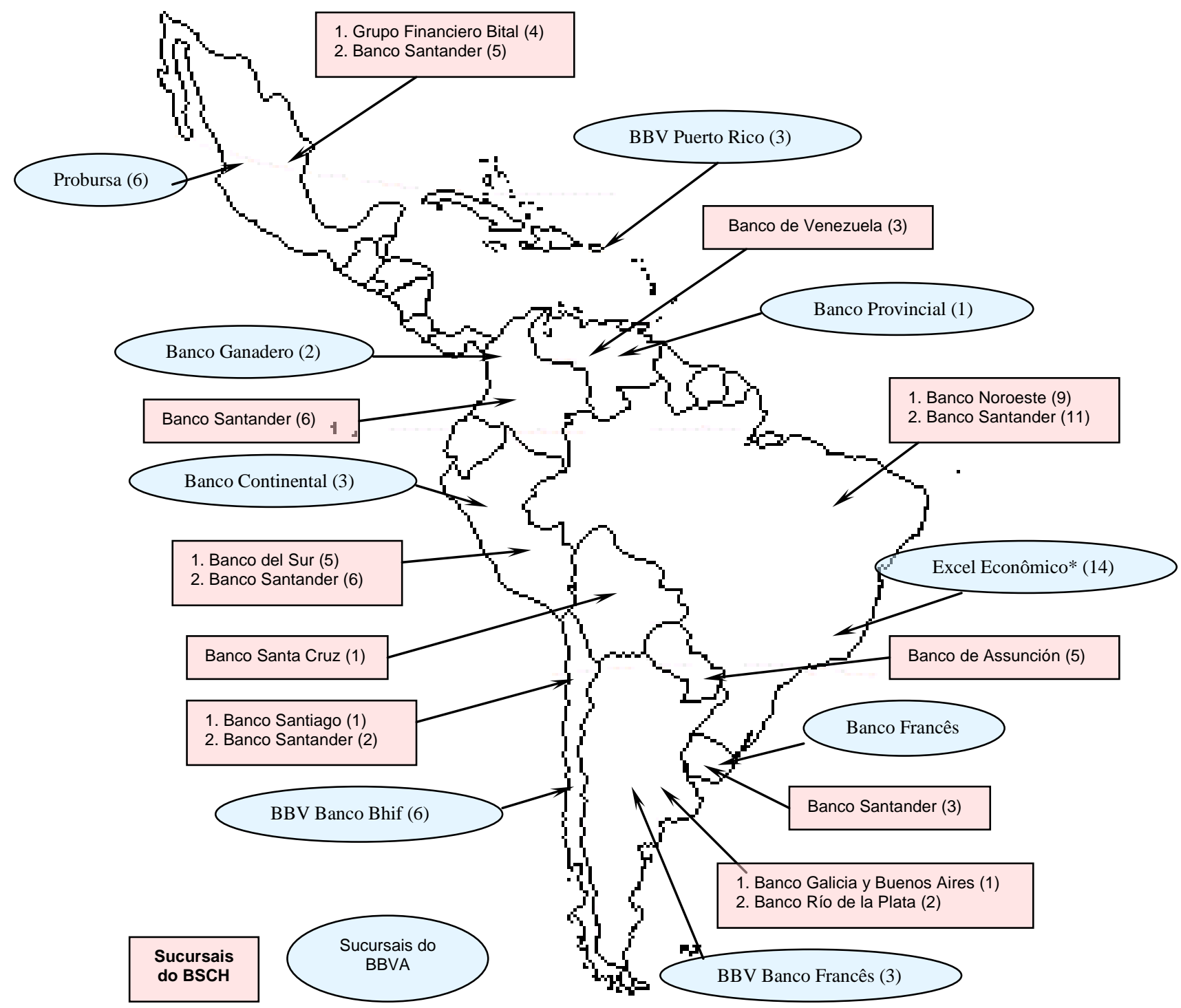

Fonte: Calderón e Casilda (2000, p. 86).

a Os números entre parênteses indicam a posição no sistema bancário nacional.

* BBV deixou o mercado do Brasil em 2003; suas operações foram adquiridas pelo Banco Bradesco. 
A tabela III.20, apresentada a seguir, representa a evolução da participação do capital bancário estrangeiro na América Latina durante a década de 1990. Os países relacionados apresentam índices crescentes dessa participação, com significativa parcela mexicana, alcançando em 2001 o maior índice verificado (90\%).

\section{Tabela III.20:}

CRESCIMENTO DA PARTICIPAÇÃO DA BANCA ESTRANGEIRA NOS ATIVOS TOTAIS DOS SISTEMAS BANCÁRIOS LATINO-AMERICANOS (EM PORCENTAGENS)

\begin{tabular}{lccccc}
\hline \multicolumn{1}{c}{ Países } & 1990 & 1994 & 1999 & 2000 & 2001 \\
\hline Argentina & 10 & 18 & 49 & 49 & 61 \\
Brasil & 6 & 8 & 17 & 23 & 49 \\
Chile & 19 & 16 & 54 & 54 & 62 \\
Colômbia & 8 & 6 & 18 & 26 & 34 \\
México & 0 & 1 & 19 & 24 & 90 \\
Peru & 4 & 7 & 33 & 40 & 61 \\
Venezuela & 1 & 1 & 42 & 42 & 59 \\
\hline
\end{tabular}

Fonte: Cepal, Informe 2002.

Na tabela III.21, podemos perceber essa participação, para o caso do Brasil, em relação aos demais países. Chama a atenção a proporção entre os EUA, a segunda maior participação estrangeira em seus bancos, em relação ao primeiro colocado (Brasil, a $8^{\text {a }}$ economia).

Tabela III.21:

\section{AS MAIORES ECONOMIAS}

\begin{tabular}{|c|l|c|}
\hline ORDEM & \multicolumn{1}{|c|}{ ECONOMIA } & $\begin{array}{c}\text { PARTICIPAÇÃO ESTRANGEIRA } \\
\text { \% nos primeiros } 15 \text { bancos }\end{array}$ \\
\hline 1 & EUA & 5 \\
\hline 2 & Japão & 0 \\
\hline 3 & Alemanha & 0 \\
\hline 4 & França & 2 \\
\hline 5 & Inglaterra & 2 \\
\hline 6 & Itália & 0 \\
\hline 7 & China & 22 \\
\hline 8 & Brasil & 3 \\
\hline 9 & Canadá & 3 \\
\hline 10 & Espanha & 0 \\
\hline 11 & Coréia do Sul & 2 \\
\hline 12 & Holanda & 4 \\
\hline 13 & Austrália & 0 \\
\hline 14 & Rússia & 0 \\
\hline 15 & Índia & 0 \\
\hline
\end{tabular}

Fonte: A. Delfim Netto, Carta Capital, 15/3/2000. 
Na tabela III.22, apresentada a seguir, encontra-se um ranking das maiores entidades bancárias mundiais, e os valores de seus ativos em 1998. Esses bancos estão associados às transações de fusões e aquisições, não apenas no setor bancário, mas também financiando aquisições ou assessorando as empresas em suas transações.

\section{Tabela III.22:}

RANKING DOS 15 MAIORES BANCOS DO MUNDO*

\begin{tabular}{ccc}
\hline $\mathrm{N}^{\mathrm{o}}$ & BANCOS & ATIVOS (US\$) \\
\hline $1^{\mathrm{o}}$ & Deutsche Bank + Dresdner Bank (Alemanha) & 1,228 trilhões \\
$2^{\mathrm{o}}$ & IBJ + DKB + Fuji (Japão) & 1,211 trilhões \\
$3^{\circ}$ & Sumitomo + Sakura (Japão) & 925 bilhões \\
$4^{\circ}$ & BNP-Paribas (França) & 690,6 bilhões \\
$5^{\circ}$ & UBS (Suiça) & 687,4 bilhões \\
$6^{\circ}$ & Citigroup (EUA) & 668,6 bilhões \\
$7^{\circ}$ & Bank of America (EUA) & 617,7 bilhões \\
$8^{\circ}$ & Bank of Tokyo Mitsubishi (Japão) & 579,8 bilhões \\
$9^{\circ}$ & Hypo Vereinsbank (Alemanha) & 540,8 bilhões \\
$10^{\circ}$ & HSBC Holdings (Grã Bretanha) + Republic New York & 534,8 bilhões \\
$11^{\circ}$ & ABN Amro Bank (Holanda) & 507,2 bilhões \\
$12^{\circ}$ & Crédit Suisse (Suíça) & 475 bilhões \\
$13^{\circ}$ & ING (Holanda) & 463,6 bilhões \\
$14^{\circ}$ & Crédit Agricole (França) & 457 bilhões \\
$15^{\circ}$ & Société Générale (França) & 450,2 bilhões \\
\hline
\end{tabular}

Fonte: Folha de São Paulo (08/03/2000).

* Estimativa baseada nos ativos de 1998.

No caso do Brasil, constata-se a participação do HSBC e do ABN Amro, grandes bancos mundiais na aquisição de bancos nacionais, como Bamerindus e Real.

Como se observa nas tabelas III.22 e III.23, dentre os quinze maiores bancos mundiais, quatro encontram-se entre as vinte maiores participações no Brasil: o ABN Amro encontra-se em $8^{\circ}$ lugar, o Citibank em $10^{\circ}$, o HSBC em $13^{\circ}$ e o Deutsche Bank em $20^{\circ}$. Desses, o ABN Amro e o HSBC entraram no mercado brasileiro após a fusão com instituições bancárias. 
Tabela III.23:

PARTICIPAÇÃO DOS 20 MAIORES BANCOS *

\begin{tabular}{|c|c|c|c|c|}
\hline \multicolumn{5}{|c|}{ 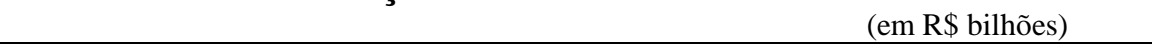 } \\
\hline & & & \multirow{3}{*}{$\begin{array}{c}\text { Crédito } \\
\text { Part. (\%) }\end{array}$} & \multirow{3}{*}{$\begin{array}{l}\text { Depósitos } \\
\text { Part. (\%) } \\
\end{array}$} \\
\hline & \multicolumn{2}{|c|}{ Ativos } & & \\
\hline & Total & Part. (\%) & & \\
\hline Banco do Brasil & 168,6 & 15,3 & 14,2 & 20,4 \\
\hline BNDES & 118,4 & 10,8 & 11,0 & 2,9 \\
\hline $\mathrm{CEF}$ & 108,4 & 9,9 & 6,3 & 18,51 \\
\hline Bradesco & 107,3 & 9,8 & 13,1 & 12,0 \\
\hline Itaú & 78,5 & 7,2 & 7,2 & 7,1 \\
\hline Santander/Banespa & 57,0 & 5,2 & 3,7 & 4,0 \\
\hline Unibanco & 55,6 & 5,0 & 6,4 & 5,1 \\
\hline ABN AMRO & 33,4 & 3,0 & 3,9 & 2,4 \\
\hline Safra & 32,2 & 2,9 & 2,4 & 2,0 \\
\hline Citibank & 26,9 & 2,5 & 2,5 & 0,3 \\
\hline BankBoston & 26,2 & 2,4 & 2,6 & 0,4 \\
\hline Nossa Caixa & 22,9 & 2,1 & 1,0 & 4,2 \\
\hline HSBC & 22,3 & 2,0 & 1,9 & 2,6 \\
\hline BBA-Creditanstalt & 16,8 & 1,5 & 1,9 & 1,2 \\
\hline Sudameris & 16,3 & 1,5 & 1,9 & 1,3 \\
\hline Bilbao Viscaya & 13,1 & 1,2 & 1,4 & 1,5 \\
\hline Votorantim & 12,5 & 1,1 & 0,5 & 1,4 \\
\hline $\mathrm{BNB}$ & 10,2 & 0,9 & 1,9 & 0,8 \\
\hline Banrisul & 9,5 & 0,9 & 1,0 & 1,4 \\
\hline Deutsch Bank & 9,3 & 0,8 & 0,3 & 0,4 \\
\hline
\end{tabular}

A tabela inserida como anexo 5, apresenta parte do histórico cronológico de fusões e aquisições no Brasil, a partir de dados da Febraban, inclusive anteriores ao período dos anos 1990, quando bancos menores eram incorporados por bancos nacionais privados ou mesmo estatais. A desnacionalização nesse setor ocorreu a partir de 1995, após a abertura bancária ao capital estrangeiro, quando grandes bancos estatais foram privatizados (caso do Banespa).

O anexo 5 apresenta a concentração bancária ocorrida na década de 1990. Diversos negócios são ilustrativos da concentração bancária e do fortalecimento de algumas instituições.

Entre 1996 e 1999, vinte e oito bancos saíram do ramo (transformaram-se em nãofinanceiras) ou faliram. São os seguintes bancos: Varig, Braseg, Criterium, Dimensão, Gulfinvest, Itamarati, Norchem, Royal, Bancred, Cambial, Crédito Metropolitano, Fiat, InterAtlântico, Iochpe, Multiplic, Vetor, Volvo, Exprinter Losan, Banco BBM, HNF (Banco de Mossoró), Síntese de Investimento, Porto Real, Estado de Roraima, Destak, Banco GE Capital, Planibanc, Estado do Acre e Tecnicorp. 


\section{III.6 Conclusões}

Vimos que alguns casos de aquisições e fusões ocorreram na história recente do país, em um período anterior ao da década de 1990. A preocupação de certos autores referia-se, principalmente, à presença de companhias estrangeiras na economia do país e ao índice de desnacionalização da economia, como em Bandeira (1975) e Mirow (1998). Entretanto, o processo de desnacionalização e a concentração da produção sob o domínio estrangeiro atingiram altos índices de participação na década de 1990. Na transição da década de 1960 para a década de 1970, houve uma preocupação generalizada, tanto no meio empresarial como nas instâncias de governo, com a fusão de empresas, objetivando melhorar as condições da empresa nacional diante de uma situação de crescente concorrência e aumento da competitividade. Porque o projeto nacional de desenvolvimento consistiu-se no planejamento Estatal de longo prazo, cujos investimentos de grande porte se concentraram nos setores estratégicos - aqueles onde a empresa nacional não detinha o volume de capital necessário como no setor elétrico, por exemplo, a construção de hidrelétricas e o retorno do investimento levam anos.

Durante a década de 1990, nada parece apontar para uma lógica de sustentação da idéia anterior, aqui resumida. Ao contrário, interessava às correntes políticas dominantes a implantação de medidas sob o argumento da redução dos gastos por parte do Estado ${ }^{142}$, e outras medidas que prejudicaram a indústria brasileira. Contraditoriamente, os recursos economizados, ou negados, ao empresariado nacional, foram liberados para bancos falidos, em um momento de risco de contaminação para todo o sistema financeiro. Naquele momento foram alteradas as regras do sistema financeiro e o governo permitiu que bancos estrangeiros assumissem parcelas maiores ou a totalidade de instituições brasileiras, inclusive estatais. $\mathrm{O}$ papel das instituições foi reconfigurado, e os bancos estaduais privatizados, passaram a competir com as demais instituições, e deixaram de lado seu anterior papel de fomento a agricultura, indústria e comércio local.

Em linhas gerais, as transações decorreram de estratégias empresariais e de busca de maior lucratividade, e causaram o aumento da concentração em diversos setores. No caso do

\footnotetext{
${ }^{142}$ Implantada com distorções, a política de privatizações acabou por ser um dos fatores da recessão...(Biondi, 1999, p. 18).
} 
setor bancário, a participação dos ativos dos maiores bancos brasileiros no ativo total do mercado passou de 45,2\% em 1994, para 60,3\% em 2003. No setor de alimentos, a Sadia participava com 52,5\% em 1994, e sua parte no setor passou a 41,3\% em 2002; a Perdigão saiu de 15,9\% (1994) e alcançou 28,4\% (2002). No setor de eletrodomésticos, a maior participação em 2002 coube à Multibrás, com 59,6\% (2002). Na indústria química, a Braskem mantinha 23,3\% de participação no mesmo ano. No setor de mineração, a liderança coube à CVRD, com 85,8\% de participação no ano considerado, e à Klabin (25,4\% em 2002) e Suzano (18,7\% em 2002) no setor de papel e celulose, etc.. ${ }^{143}$

${ }^{143}$ Folha de S. Paulo, 08/03/2004. 


\section{CONSIDERAÇÕES FINAIS}

O presente trabalho procurou estabelecer uma interlocução entre os diversos autores e abordagens relacionados no capítulo teórico, a partir da concepção de concentração e de centralização de capital, com o processo histórico atual.

Muitas vezes, principalmente na linguagem jornalística, o tratamento dispensado ao assunto não passa do episódico, ou casual, porém quase desprovido da sua "causalidade". A base teórica, portanto, remete a esse movimento de causa e efeito. Deve-se ressaltar que o chamado movimento de fusão e aquisição de empresas é uma espécie de resposta, de configuração de um novo arranjo na ordem econômica, causada pela ocorrência de uma crise, normalmente associada às fases depressivas dos ciclos longos. Assim, há uma repetição que conduz à concentração da participação das empresas em um certo mercado, ou ao domínio de poucas empresas em certos setores. Uma contração que sugere a procura de uma nova expansão da empresa.

A "globalização" foi vista como um aspecto importante na associação do tema com a Geografia, a fim de se ressaltar a relevância do território e do espaço, além da discussão referente ao atual papel do Estado. No caso dos EUA, por exemplo, as empresas privadas norte-americanas atuam também de acordo com os interesses e as políticas e estratégias associadas a diretrizes governamentais. No caso do Japão, como visto anteriormente, o governo procura priorizar as empresas de capital japonês, dificultando o aumento da participação bancária estrangeira nas instituições bancárias de seu país, visto que o Estado controla a economia do país.

Parece relevante discutir as fusões, aquisições e privatizações do ponto de vista da Geografia, pois as empresas desencadeiam ações que influenciam os locais, a mão-de-obra, os mercados e os países onde atuam. Elas atuam conforme uma série de estratégias, dentre elas as estratégias de expansão geográfica. É importante ressaltar a interação entre as estratégias das empresas, as consequiências de sua atuação, assim como a forma como essa relação se estabelece com a sociedade.

Circunscrever o tema em uma comparação entre países com realidades e em contextos distintos, pode ser útil para se verificar os mecanismos semelhantes ou diferentes, e analisar 
esse processo que redundou em liberalização econômica, reformas e privatizações, e possibilitou ou mesmo incentivou, no caso do Brasil, a realização de diversas fusões e aquisições.

No caso do setor elétrico brasileiro, por exemplo, as privatizações caracterizaram-se pelo desmonte do anterior sistema, que caracterizava-se pela sua complexidade, mas era também muito eficiente, baseado na grande disponibilidade hídrica do país, e a transferência de muitas empresas à participação estrangeira. Um modelo de privatização equivocado - com participação estrangeira crescente no setor, que apresentou crise de abastecimento (o conhecido “apagão"), proposta de geração de energia mais cara, através das termoelétricas, algo irrealista para as condições do país, diminuição do poder decisório de órgãos do governo e de planejamento governamental - nada no modelo de privatização do setor elétrico do país parece exemplar ou tem a aura do êxito. Lembre-se que o setor elétrico brasileiro, desmontado em menos de cinco anos, foi construído ao longo de décadas, como o resultado do esforço de vários governos e da história de lutas pelo desenvolvimento econômico e industrial brasileiro.

As reformas empreendidas no Reino Unido tornaram-se exemplares para outros países. Entretanto, o modelo lá aplicado serviria a países em desenvolvimento? Ou seja, a realidade de um país aonde, por exemplo, a questão da moradia havia se resolvido com uma locação subsidiada, se aplicaria de maneira tão simples na América Latina, região com grande desigualdade social? Um detalhe do modelo neoliberal aplicado no Reino Unido: a criação de um mecanismo de controle do governo em empresas estratégicas ou de segurança nacional, para evitar o controle estrangeiro. Assim como em outros países foram preservados setores ou empresas estratégicas.

O modelo foi implementado como uma fórmula possível e única para a saída da crise, após a disseminação de uma propaganda contrária ao papel do Estado enquanto agente econômico, e que seria o causador das distorções. A alternativa possível, portanto, principalmente aos países latino-americanos, encontrava-se na subordinação aos ditames da "globalização", e à assertiva da preponderância do mercado, através de medidas concretas como a privatização e a desregulamentação. Diante da crise, da situação de sujeição às orientações dos organismos financeiros mundiais, a solução encontrada foi a de respeitar as orientações externas, realizar acordos lesivos ao patrimônio e ao crescimento econômico, cujo resultado mais flagrante foi a ampliação da taxa de desemprego na América Latina, em índices jamais vistos em períodos anteriores. 
No Brasil, o chamado "Estado-empresário" foi enfraquecido, o planejamento tornouse obsoleto, e as consequiências parecem desastrosas nos setores de infra-estrutura, nos serviços públicos privatizados agora com tarifas a preços exorbitantes, nos índices ainda altos de desemprego em 2004, no tecido social carente de serviços básicos como saúde e educação, etc.. O resultado das vendas das privatizações não seria investido no setor social? Não seria utilizado para diminuir a dívida do país? A alienação do patrimônio nacional, de empresas estratégicas para o desenvolvimento do país, que poderiam ter sido utilizadas na superação da crise cíclica, em um processo lícito de concessão de serviços públicos em benefício da sociedade, e não apenas para o privilégio de determinados grupos, efetivamente não ocorreu. Assim, foi reduzida a participação do Estado na economia, mas o governo não hesitou em conceder financiamentos a bancos privados quebrados. Por outro lado, saneou, assumiu dívidas e preparou o terreno para os novos proprietários (estrangeiros) de importantes bancos públicos, como o Bemge, Banespa, Banerj, etc.; cortou gastos, e leiloou empresas estatais, ou seja, alienou o patrimônio nacional, em uma opção que ampliou a participação de empresas estrangeiras e dos investimentos estrangeiros na economia, através da aquisição de ativos existentes e não do investimento em novos ativos na produção ou na infra-estrutura.

No caso do Brasil, as empresas se depararam com uma série de dificuldades, causadas pela abertura econômica, e com pouco ou nenhum apoio de instâncias de governo. O que preponderou, no período, foi a atuação do setor financeiro, com liberdade para se reestruturarem, dispensarem trabalhadores após os processos de fusão ou aquisição e auferirem lucros com base no aumento de tarifas mas principalmente pela manutenção das altas taxas de juros no período.

A década foi marcada, também, pelo aumento expressivo das transações transfronteiriças, e pela realização de grandes transações principalmente nos setores de telecomunicações, financeiro e petrolífero.

Na América Latina, a participação de empresas dos EUA é significativa, entretanto, cresceu a participação de empresas de outros países no Brasil, nos setores financeiro (Banco Santander, BBVA, ABN Amro Bank, etc.) e de telecomunicações (Telefônica de Espanha, Portugal Telecom, Telmex, etc). É bastante significativa, também, a presença de estrangeiros no setor de varejo: Wal Mart, Carrefour, Royal Ahold, Sonae, entre outros.

De qualquer forma, os dados parecem indicar que, no Brasil, o ponto máximo das transações já foi alcançado, na medida em que grandes empresas estatais já foram vendidas, 
como as empresas do sistema Telebrás, assim como as empresas de telefonia regional e a maior parte dos bancos estatais estaduais, entre outras grandes empresas (Cia Vale do Rio Doce, etc). Mas o movimento - e a concorrência - continuam intensos. Dos bancos estaduais ainda não privatizados, restaram os Bancos do Piauí, do Ceará e o de Santa Catarina, o BESC, cuja privatização enfrenta a aposição do governador do estado. O Banco do Estado do Maranhão, privatizado em 10 de fevereiro de 2004, foi adquirido pelo Bradesco por R\$ 78 milhões. Esta foi a primeira privatização do governo Luís Inácio Lula da Silva, associada pelos meios financeiros (onde a privatização foi bastante comemorada) ao grau de responsabilidade do governo. Logo no primeiro ano de governo, ocorreu uma re-negociação entre a AES e o BNDES, empresa norte-americana do setor elétrico, proprietária da Eletropaulo e de dez usinas hidrelétricas no Estado de São Paulo, além de participações da AES em companhias em outros estados. A AES não havia saldado os financiamentos adquiridos junto ao BNDES no governo FHC. A dívida alcançava, no início do ano de 2003, cerca de US\$ 1,2 bilhão. Pelo acordo, considerado "necessário e inevitável", o BNDES tornou-se sócio da AES em uma nova empresa, a Brasiliana, e o saldo devedor da AES foi dividido por $11 \operatorname{anos}^{144}$.

Entretanto, a decisão do CADE, em 2004, vetando a aquisição da fábrica da Chocolates Garoto pela Nestlé, foi intensamente questionada por representantes da multinacional e pelo governador do Espírito Santo. A decisão do órgão responsável pela defesa da concorrência no país parece adequada, pois haveria o aumento da participação da Nestlé no segmento de chocolates, mas contrariou os interesses de uma grande empresa. Destaque-se que o CADE, até $1990^{145}$, julgava 1,4 processo por mês, e em dezembro de 1997 (governo de FHC) julgou 132 processos. As decisões sobre atos de concentração passaram, de uma média de 169 para a média de 61 dias, e em 1997 resolveu casos pendentes há três anos, e que, conforme Gesner Oliveira, então presidente do CADE, estariam prejudicando o programa de privatizações.

A iminência de outros negócios também tem mobilizando o CADE, como o da associação entre a Ambev e a Interbrew, questionada pela cervejaria Schincariol.

No setor de telefonia também ocorreram negócios e associações, como por exemplo, a formação do consórcio Calais Participações, entre as operadoras de telefonia fixa Telemar,

\footnotetext{
${ }^{144}$ Folha de São Paulo, 14/09/03 e 17/01/2004

${ }^{145}$ Folha de S. Paulo, 01/01/1998.
} 
Brasil Telecom e Telefônica, na disputa pela Embratel, cuja decisão foi proferida pela justiça norte-americana, por causa da falência da antiga proprietária, a MCI. A decisão da justiça norte-americana favoreceu à empresa mexicana Telmex (que pagou US\$ 400 milhões pela Embratel). A Telmex, proprietária da Telet e Americel (empresas do grupo Claro, que atuam no Rio Grande do Sul e na região Centro-Oeste) adquiriu, em fevereiro de 2004 os ativos da AT\&T Latin America no Brasil, e tem interesse na aquisição de parte da Net Serviços, maior operadora de TV por assinatura do país pertencente ao grupo Globo de Televisão ${ }^{146}$.

O levantamento de fusões e aquisições da KPMG também mostra o aumento das operações envolvendo participação estrangeira, além de considerar os negócios realizados entre empresas nacionais (transações domésticas) no período 1992-2004. Os dados assinalam a evolução dos negócios com maior participação estrangeira no Brasil, e o predomínio dessas transações, principalmente no período 1994 até 2001, quando então diminuíram, tanto em termos da participação estrangeira como na quantidade de negócios fechados no país.

Além dos altos índices de desemprego que percorreram toda a década de 1990, outro fator importante a ser ressaltado refere-se ao caso da Bolsa de Valores do Rio de Janeiro, fechada após a grande onda de privatização da segunda metade dos anos 1990. Atualmente uma parcela irrisória dos títulos do setor energético, siderúrgico, telecomunicações e de mineração são comercializados na Bolsa de Valores de São Paulo, enquanto a parte expressiva das ações é comercializada no exterior.

Frente a esse quadro, o papel do Estado enquanto agente de fomento do crescimento econômico e do desenvolvimento das forças de produção, desde 1930, apresenta-se alterado diante da atual "modernização" - retrógrada, por assim dizer - pois os governos neoliberais favoreceram setores relacionados ao sistema financeiro em detrimento dos setores produtivos. Retrógrada, no sentido que Rangel (1991) ${ }^{147}$ se referia à "apostasia":

Não é acidental que as forças sociais decisivas da sociedade saída da revolução industrial - o empresariado e proletariado industriais - resistam tão energicamente a esse pacto social que lhe querem impor, que os subordine a um retrógrado "Plano Brasil Novo", orientado para um absurdo combate à inflação pela recessão; para uma reintegração do Brasil no mercado mundial, via desmantelamento das nossas reservas institucionais de mercado, etc. (Rangel, 1991)

\footnotetext{
${ }^{146}$ Folha de S, Paulo, 15/05/2004.

${ }^{147}$ Em artigo publicado no jornal Folha de S. Paulo, 02/01/1991, sob o título "Apostasias".
} 
O país tornou-se mais dependente de capital estrangeiro nos anos 1990, por falta de um projeto nacional calcado na necessidade da retomada do crescimento econômico, ocasião em que foram desperdiçados o patrimônio da nação, a sua mão de obra e os seus recursos naturais.

Deve-se destacar que o processo de privatizações foi precedido por demissões, cortes de gastos e de investimentos, com as estatais sendo "saneadas" pelo governo antes das privatizações, o que causou aumento dos seus lucros logo após a privatização e a falsa impressão do melhor desempenho da empresa estatal privatizada. Conforme Biondi (1999), no estado de São Paulo, por exemplo, foram mais de 10.000 demissões na FEPASA, de 1995 a 1998, com o governo se encarregando do pagamento das indenizações e direitos trabalhistas, antes da privatização. No Rio de Janeiro, o governo demitiu 6.200 dos 12.000 funcionários do Banerj, livrando os compradores do Banco do pagamento de indenizações e aposentadorias ${ }^{148}$.

Do total de privatizações realizadas no país, coube ao governo Collor, em menos de dois anos, a privatização de 15 empresas, entre elas a Usiminas, a Mafersa, a Celma, a Cosinor, a Álcalis, a Copesul, a Fosfértil, entre outras, que geraram $\mathrm{R} \$ 4.076$ milhões. O governo de Itamar Franco deu continuidade ao cronograma estabelecido, e privatizou 18 empresas, entre elas: Goiás Fértil, Acesita, Poliolefinas, CSN, Ultrafértil, Cosipa, Açominas, Ciquine, Embraer, entre outras, arrecadando R \$ 4,135 milhões. Note-se que nas privatizações, até o final desse período, a participação de grupos, consórcios ou empresas brasileiras era majoritária.

A segunda fase do programa, inaugurada por Fernando Henrique, não apresentaria a mesma característica: as privatizações foram totalmente abertas, inclusive no setor financeiro, à participação estrangeira, com a deformidade dos financiamentos do BNDES às grandes empresas estrangeiras. O governo Fernando Henrique notabilizou-se, inclusive, porque ocorreram articulações em detrimento de certos grupos ou em benefício de outros, como ocorreu no caso da privatização do Sistema Telebrás, onde suspeitou-se de "tráfico de influência", que envolveu inclusive a figura do Ministério das Comunicações.

Em seu governo foram leiloadas empresas dos setores: elétrico, petroquímico, ferroviário, mineração, portuário, financeiro e de telecomunicações. Empresas importantes, estratégicas para o desenvolvimento do país e o crescimento econômico, que geravam divisas, foram vendidas, como a Companhia Vale do Rio Doce, as empresas do Sistema Telebrás, a

\footnotetext{
${ }^{148}$ Biondi, 1999, p. 9.
} 
Escelsa, etc.. Só no período equivalente ao do primeiro mandato, o governo de Fernando Henrique arrecadou R \$ 27,646 milhões com as privatizações das mencionadas empresas.

Em 1991, ao final de seu artigo, Rangel afirmava a brevidade da nossa apostasia, pois ela seria um movimento contrário ao "processo vitorioso e irreversível", que não deveria ser aceito pelas classes oprimidas ou pelas classes dirigentes (o empresariado), pois às primeiras restaria o desemprego e "para as últimas, a insolvência e a falência" (Rangel, 1991). O autor vislumbrou as conseqüências do processo em seu início, e percebeu as futuras e graves consequiências de sua implantação. 


\section{REFERÊNCIAS BIBLIOGRÁFICAS}

ANDERSON, Perry. "Balanço do neoliberalismo". In: SADER, Emir e GENTILI, Pablo. Pós-neoliberalismo: As políticas sociais e o Estado democrático. Rio de Janeiro: Paz e Terra, 1995.

ANDRADE, Manuel Correia de. Uma Geografia para o século XXI. Campinas: Papirus, 1994.

ARROYO, Mercedes. “Alfred D. Chandler Jr. y el debate en torno a su obra intelectual”. In: Revista Bibliográfica de Geografia y Ciencias Sociales, $\mathrm{n}^{\circ}$ 141, Universidad de Barcelona, 4 de marzo de 1999.

AZEVEDO, Eduardo da Rocha. “A próxima vítima”. In: Folha de São Paulo, 29/05/2002.

BANDEIRA, Moniz. Cartéis e desnacionalização - a experiência brasileira: 1964-1974. Rio de Janeiro: Civilização Brasileira, 1975.

BARROS, Betania Tanure de (org.). Fusões, Aquisições \& Parcerias. São Paulo: Atlas, 2001. Fusões e Aquisições no Brasil. São Paulo: Atlas, 2003.

BATISTA, Paulo Nogueira. "O Consenso de Washington - a visão neoliberal dos problemas latino-americanos”. In: Consulta Popular, cartilha n 7, novembro/1999.

BATISTA JR., Paulo Nogueira. “'Globalização' e administração tributária”. In Revista Princípios, set./97.

BIONDI, Aloysio. O Brasil Privatizado - um balanço do desmonte do Estado. São Paulo: Editora da Fundação Perseu Abramo, 1999. O Brasil Privatizado II. Editora da Fundação Perseu Abramo, 2000.

BNDES. "Fusões e aquisições no setor de alimentos". In: Informe Setorial, no 15, abril/1999a (Gerência Setorial 1).

BNDES. A Economia Brasileira nos Anos 90. Brasília: BNDES, $1999 \mathrm{~b}$.

BNDES. "Impactos da privatização no setor siderúrgico". In:BNDES (Área de Operações Industriais - Gerência Setorial de Mineração e Metalurgia), novembro/2000.

BNDES. "Reestruturação na siderurgia brasileira". In: BNDES (Gerência Setorial de Mineração e Metalurgia), 2002. 
BONELLI, Régis. "Fusões e aquisições no Mercosul". In: Veiga, Pedro da Motta (org.). $O$ Brasil e os desafios da globalização. Rio de Janeiro: SOBEET e Relume Dumará, 2000a.

.Fusões e aquisições no Mercosul”. In: Textos para Discussão, n 718, IPEA, Brasília, abril/2000b.

BORTONI, Larissa e MOURA, Ronaldo de. O mapa da corrupção no governo FHC. São Paulo: Editora Fundação Perseu Abramo, 2002.

BOTTOMORE, Tom. "Introdução à Edição Inglesa". In Hilferding, R. O Capital Financeiro. São Paulo: Nova Cultural, 1985.

BROWNE, Anthony. "Os ensinamentos do Reino Unido". In: GRIMSTONE, Gerry (et al.). Privatização, Mercado de capitais e democracia - a recente experiência internacional. Rio de Janeiro: Correio da Serra, 1988.

BUKHARIN, Nikolai I. A economia mundial e o imperialismo. São Paulo: Nova Cultural, 1988.

CALDEIRA, Jorge. Mauá - Empresário do Império. São Paulo: Companhia das Letras, 2002.

CALDERÓN, Alvaro e CASILDA, Ramón. "La estratégia de los bancos espanholes en América Latina". In:Revista de La Cepal, nº 70, abril, 2000.

CANO, Wilson. Soberania e política econômica na América Latina. São Paulo: Unesp, 1999.

CARRION, Raul K. M. e VIZENTINI, Paulo G. Fagundes. Globalização, neoliberalismo, privatizações: quem decide este jogo? Porto Alegre: UFRGS e CEDESP, 1997.

CARROL, Paul. Big Blues - a derrocada da IBM. Rio de Janeiro: Ediouro, 1994.

CASTRO, Marcio Henrique M. de \& BIELSCHOWSKY, Ricardo. "Contribuição de Ignacio Rangel ao pensamento econömico brasileiro". In: RANGEL, Ignacio. Economia Brasileira Contemporânea. São Paulo: Bienal, 1987.

CEPAL. "Inversión Estranjera en América Latina y el Caribe". In: Informe 1998, Cepal, Naciones Unidas, 1998.

CEPAL. "Inversión Estranjera en América Latina y el Caribe". In: Informe 1999, Cepal, Naciones Unidas, 2000.

CEPAL. "Inversión Estranjera en América Latina y el Caribe". In: Informe 2002, Cepal, Naciones Unidas, 2002.

CHAMPI JR., Afonso e BARBOSA, Djalma Gonçalves. Diário de uma crise - lições do caso Parmalat. Rio de Janeiro: Qualitymark, 2004. 
CHESNAIS, François. A mundialização do capital. São Paulo: Xamã, 1996.

CHUAY, Eduardo e VICTER, Wagner G. A construção e a destruição do setor elétrico brasileiro - uma análise crítica e histórica - de Getúlio Vargas a Fernando Henrique Cardoso. Rio de Janeiro: Relume Dumará, 2002.

COMIN, Alexandre. "O crescimento das fusões e aquisições no Brasil e no mundo: uma avaliação das tendências recentes”. In: LEP, Campinas, Unicamp (3): 63-87, dez. 1996.

DREIFUSS, René Armand Dreifuss. Transformações: matrizes do século XXI. Petrópolis (RJ): Editora Vozes, 2004.

DUPAS, Gilberto. "O Brasil, suas Empresas e os Desafios da Competição Global”. In: BARROS, Betania Tanure de. Fusões, Aquisições \& Parcerias. São Paulo: Atlas, 2001.

ESPÍNDOLA, Carlos José. As agroindústrias no Brasil [O caso Sadia]. Chapecó: Grifos, 1999.

FERRAZ, João Carlos \& IOOTY, Mariana. "Fusões, aquisições e internacionalização patrimonial no Brasil nos anos 90”. In: VEIGA, Pedro da Motta (org.). O Brasil e os desafios da globalização. Rio de Janeiro: SOBEET e Relume Dumará, 2000.

GAZETA MERCANTIL. Balanço Anual. Ano XXVI, nº 26, junho de 2002.

GONÇALVES, Reinaldo. Globalização e desnacionalização. São Paulo: Paz e Terra, 1999.

"Centralização do capital em escala global e a desnacionalização da economia brasileira". In: VEIGA, Pedro da Motta (org.). O Brasil e os desafios da globalização. Rio de Janeiro: SOBEET e Relume Dumará, 2000.

A herança e a ruptura - cem anos de história econômica e propostas para mudar o Brasil. Rio de Janeiro: Garamond, 2003.

GRIMSTONE, Gerry (et al.). Privatização, Mercado de capitais e democracia - a recente experiência internacional. Rio de Janeiro: Correio da Serra, 1988.

. "20 bilhões de libras em 8 anos" In: GRIMSTONE, Gerry (et al.). Privatização, Mercado de capitais e democracia - a recente experiência internacional. Rio de Janeiro: Correio da Serra, 1988.

HARBISON, John R. e PEKAR JR, P. Alianças estratégicas. São Paulo: Editora Futura, 1999. 
HEAU, Dominique. "Mania de Fusões". In: BARROS, Betania Tanure de. Fusões, Aquisições \& Parcerias. São Paulo: Atlas, 2001.

HILFERDING, Rudolf. O capital financeiro. São Paulo: Nova Cultural, 1985.

HIRST, Paul \& THOMPSON, G. Globalização em questão. Petrópolis (RJ): Vozes, 2001.

IPSO (org.). A causa nacional - o futuro da nação brasileira. São Paulo: Editora Senac S. Paulo, 1998.

KORTEN, David C. Quando as corporações regem o mundo. São Paulo: Editora Futura, 1996.

KPMG. Pesquisa Fusões \& Aquisições - Transações Realizadas no Brasil. São Paulo: Diversos números. .Fusões \& Aquisições no Brasil - Análise dos anos 90. São Paulo: 2000.

LACERDA, Antonio Corrêa de. O impacto da globalização na economia brasileira. São Paulo: Contexto, 1999.

. "Dos investidores tradicionais, apenas os EUA mantiveram atitude agressiva". In: O Estado de São Paulo, 19/02/2000.

LEITE, Paulo de Tarso Soares. "Imperialismo e políticas neoliberais". In: GADELHA, Regina M.A.F. Globalização, metropolização e políticas neoliberais. São Paulo: Educ, 1997.

LÊNIN, Vladimir Ilich. O imperialismo, fase superior do capitalismo. São Paulo: Centauro Editora, 2000.

LESBAUBIN, Ivo. O desmonte da Nação - Balanço do governo FHC. Petrópolis (RJ): Vozes, 2000.

LESBAUPIN, Ivo e MINEIRO, Adhemar. O desmonte da Nação em dados. Petrópolis (RJ): Vozes, 2002.

LODI, João Bosco. A nova empresa para os anos 90 - lições da década perdida. São Paulo: Livraria Pioneira Editora, 1993.

. Fusões e aquisições - o cenário brasileiro. Rio de Janeiro: Campus, 1999.

MAMIGONIAN, Armen. (Org.). O Pensamento de Ignácio Rangel. Florianópolis: UFSC, 1997.

"A América Latina e a economia mundial: notas sobre os casos chileno, mexicano e brasileiro". In: Geosul, Ed. UFSC (28): 139-151, jul./dez. 1999. 
."Tecnologia e desenvolvimento desigual no centro do sistema". In: Revista Ciências Sociais, Ed. UFSC, nº 2, 1982.

.’Notas sobre os frigoríficos do Brasil Central Pecuário". In: Boletim Paulista de Geografia, nº 51, AGB-Seção SP, São Paulo, jun. 1976.

MANEY, Kevin. O futuro da megamídia. São Paulo: Makron Books, 1997.

MATOS $\mathrm{F}^{\mathrm{o}}$, José C. e OLIVEIRA, Carlos Wagner de A. "O processo de privatização das empresas brasileiras”. In: Texto para Discussão n 422, maio de 1996.

MCCRAW, Thomas K. (Org.). Alfred Chandler: ensaios para uma teoria histórica da grande empresa. Rio de Janeiro: Editora Fundação Getúlio Vargas, 1998.

MARX, Karl. O capital. Livro Primeiro, Vol. II. Rio de Janeiro: Civilização Brasileira, 1968.

MIRANDA, José Carlos \& MARTINS, Luciano. "Fusões e aquisições de empresas no Brasil". In: Economia e Sociedade, Campinas (14): 67-88, jun. 2000.

MIROW, Kurt Rudolph. A ditadura dos cartéis (anatomia de um subdesenvolvimento). Rio de Janeiro: Civilização Brasileira S.A., 1978.

MOREIRA, Maurício Mesquita. "Estrangeiros em uma economia aberta: impactos recentes sobre produtividade, concentração e comércio exterior". In: Textos para Discussão, $\mathrm{n}^{\circ}$ 67, BNDES, Rio de Janeiro, março, 1999.

MOURA, Aristóteles. Capitais estrangeiros no Brasil. São Paulo: Brasiliense, 1959.

OLIVEIRA, Gesner. Concorrência - panorama no Brasil e no mundo. São Paulo: Editora Saraiva, 2001.

PAULA, Luiz Fernando Rodrigues de. "Los determinantes del reciente ingresso de bancos extranjeros a Brasil". In: Revista de La Cepal, n 79, abril, 2003.

PÉCORA, José Flávio e outros. Simpósio sobre fusões e incorporações. São Paulo: Mestre Jou, 1972.

.Fusão! por que não? Rio de Janeiro: José Olympio Editora, 1972b.

PIRIE, Madsen e YOUNG, Peter. "O futuro da privatização". In: GRIMSTONE, Gerry (et al.). Privatização, Mercado de capitais e democracia - a recente experiência internacional. Rio de Janeiro: Correio da Serra, 1988.

PIRES, José Cláudio Linhares e DORES, Adely Branquinho das. "Fusões e aquisições no setor de telecomunicações: características e enfoque regulatório”. In: Textos para Discussão, nº 83, BNDES, Rio de Janeiro, 2000. 
PIZZO, Maria do Rosário. "Rangel e a concessão de serviços públicos à iniciativa privada". In: Mamigonian, A. O Pensamento de Ignácio Rangel. Florianópolis: UFSC/PPGG, 1997.

POCHMANN, Marcio. A década dos mitos - o novo modelo econômico e a crise do trabalho no Brasil. São Paulo: Editora Contexto, 2001.

RANGEL, Ignácio.Dualidade básica da economia brasileira. São Paulo: Bienal, 1999, 2a edição.

.Economia Brasileira Contemporânea. São Paulo: Bienal, 1987.

Economia: milagre e anti-milagre. Rio de Janeiro: Jorge Zahar, 1985.

."Esta crise não se administra". In: Revista de Economia Política, vol. 3, n 3, julho-setembro/1983.

."A questão financeira”. In: Revista de Economia Política, vol. 1, nº 1, janeiro -março/1981.

RASMUSSEN, U. W. Aquisições, fusões \& incorporações empresariais. São Paulo: Aduaneiras, 1989.

Holdings e Joint Ventures - uma análise transacional de consolidações e fusões empresariais. São Paulo: Aduaneiras, 1991.

RIBEIRO, Luiz Dario. "Privatizações na Grã-Bretanha". In: CARRION, Raul K. M. e VIZENTINI, Paulo G. Fagundes. Globalização, neoliberalismo, privatizações: quem decide este jogo? Porto Alegre: UFRGS e CEDESP, 1997.

RODRIGUES, Rute I. "Empresas estrangeiras e fusões e aquisições: os casos dos ramos de autopeças e de alimentação/bebidas em meados dos anos 90”. In Textos para discussão, no 622, IPEA, Brasília, 1999.

ROSSETI, Paschoal. "Fusões e Aquisições no Brasil: as razões e os impactos". In: BARROS, Betania T. de. Fusões, Aquisições \& Parcerias. São Paulo: Atlas, 2001.

SADER, Emir e GENTILI, Pablo. Pós-neoliberalismo: as políticas sociais e o Estado democrático. Rio de Janeiro: Paz e Terra, 1995.

SANDRONI, Paulo. Novíssimo Dicionário de Economia. São Paulo: Editora Best Seller, 2002.

SANTOS, Milton. Por uma outra globalização. Rio de Janeiro, São Paulo: Record, 2000. 
SCHMIDT, Carlos. "A privatização da siderurgia no Brasil”. In: CARRION, Raul K. M. e VIZENTINI, Paulo G. Fagundes. Globalização, neoliberalismo, privatizações: quem decide este jogo? Porto Alegre: UFRGS e CEDESP, 1997.

SZMRECSANYI, Tamas. "A era dos trustes e cartéis”. In: História e Energia: a chegada da Light. São Paulo, Departamento do Patrimônio Histórico/Eletropaulo, 1986.

SWEEZY, Paul M. Teoria do desenvolvimento capitalista. Rio de Janeiro: Zahar, 1967.

TAVARES, Maria da Conceição; e FIORI, José Luís. (Des)Ajuste Global e Modernização Conservadora. Rio de Janeiro: Paz e Terra, 1993.

TRICHES, Divanildo. "Fusões, aquisições e outras formas de associação entre empresas no Brasil”. In: Revista de Administração, São Paulo, v. 31, nº 1: 14-31, jan-mar., 1996.

VEGRO, Celso Luis Rodrigues e SATO, Geni Satiko. "Fusões e aquisições no setor de produtos alimentares”. In: Informações Econômicas, São Paulo, v. 25, nº 5, mai-1995.

VEIGA, Pedro da Motta (org.). O Brasil e os desafios da globalização. Rio de Janeiro: SOBEET e Relume Dumará, 2000.

América Economia

\section{Periódicos:}

Carta Capital

Folha de S. Paulo

Forbes Brasil

Gazeta Mercantil

O Estado de S. Paulo

Reportagem - Revista da Oficina de Informações

Revista Atenção

Revista Istoé

Revista Veja

Valor Econômico 
ANEXOS 
Anexo 1:

AS 100 EMPRESAS MAIS COMPETITIVAS DA AMÉRICA LATINA

\begin{tabular}{|c|c|c|}
\hline EMPRESA/SETOR & PAÍS & $\begin{array}{l}\text { VENDAS } 2002 \\
\text { (US\$ milhões) }\end{array}$ \\
\hline Ledesma/Agroindústria & Argentina & 167,7 \\
\hline Quickfood/Alimentos & Argentina & 104,0 \\
\hline Aceitera General Deheza/Alimentos & Argentina & 823,3 \\
\hline Arcor/Alimentos & Argentina & 360,7 \\
\hline Molinos Rio de La Plata/Alimentos & Argentina & 509,3 \\
\hline Coto/Comércio & Argentina & $1.676,9$ \\
\hline Patagônia/Comércio & Argentina & 281,8 \\
\hline Tenaris/Siderurgia-Metalurgia & Argentina & $1.331,6$ \\
\hline Iguaçu Café/Alimentos & Brasil & 63,5 \\
\hline Sadia/Alimentos & Brasil & $1.031,6$ \\
\hline Perdigão/Alimentos & Brasil & 713,1 \\
\hline Marcopolo/Autopeças & Brasil & 362,7 \\
\hline Busscar/Autopeças & Brasil & 194,8 \\
\hline Ambev/Bebidas & Brasil & $1.807,6$ \\
\hline Grendene/Calçados & Brasil & 282,3 \\
\hline Azaléia/Calçados & Brasil & 259,7 \\
\hline Suzano/Celulose e Papel & Brasil & $1.161,1$ \\
\hline Votorantim/Celulose e Papel & Brasil & 433,9 \\
\hline Aracruz/Celulose e Papel & Brasil & 428,4 \\
\hline Globes (Ponto Frio) /Comércio & Brasil & 599,7 \\
\hline Pão de Açúcar (CBD) /Comércio & Brasil & $2.283,0$ \\
\hline Lojas Americanas/Comércio & Brasil & 389,8 \\
\hline Natura/Cosméticos & Brasil & 510,6 \\
\hline Camargo Correa/Engenharia e Construção & Brasil & 519,5 \\
\hline Odebrecht/Engenharia e Construção & Brasil & $3.129,0$ \\
\hline Gradiente/Eletrônica & Brasil & 134,7 \\
\hline Itaú & Brasil & $25.421,4$ \\
\hline Bradesco & Brasil & $35.983,2$ \\
\hline Petrobrás/Hidrocarbonetos & Brasil & $15.866,2$ \\
\hline Embraer/Ind. Aeroespacial & Brasil & $1.627,1$ \\
\hline WEG/Máquinas & Brasil & 297,5 \\
\hline Tigre/Materiais de Construção & Brasil & 367,5 \\
\hline Vale do Rio Doce/Mineração & Brasil & $1.877,0$ \\
\hline Gerdau & Brasil & $2.027,0$ \\
\hline Telemar & Brasil & $2.922,0$ \\
\hline Coteminas/Têxtil & Brasil & 215,1 \\
\hline Andina/Bebidas & Chile & 554,4 \\
\hline Celulosa Arauco/Celulose e Papel & Chile & $1.089,0$ \\
\hline Papeles y Cartones (CMPC)/Celulose e Papel & Chile & $1.169,5$ \\
\hline Sodimac/Comércio & Chile & 721,5 \\
\hline Falabella/Comércio & Chile & $1.118,5$ \\
\hline FASA/Comércio & Chile & 412,7 \\
\hline D\&S/Comércio & Chile & $1.351,3$ \\
\hline Cencosud/Comércio/Comércio & Chile & $1.041,7$ \\
\hline Lan Chile/Companhias Aéreas & Chile & $1.273,9$ \\
\hline BESALCO/Engenharia e Construção & Chile & 91,9 \\
\hline Altas Cumbres & Chile & 172,4 \\
\hline COPEC/Hidrocarbonetos & Chile & $3.111,0$ \\
\hline SQM/Mineração & Chile & 503,4 \\
\hline Codelco/Mineração & Chile & $3.576,9$ \\
\hline Enaex/Química-Laboratórios & Chile & 150,3 \\
\hline Molymet/Química-Laboratórios & Chile & 173,8 \\
\hline Andrómaco/Química-Laboratórios & Chile & 49,0 \\
\hline
\end{tabular}




\begin{tabular}{|c|c|c|}
\hline Banmédica/Serviços & Chile & 368,8 \\
\hline Zalaquet/Têxtil & Chile & 5,9 \\
\hline Sudamericana de Vapores/Transportes & Chile & $1.514,7$ \\
\hline Cristalerías Chile/Vidro & Chile & 204,1 \\
\hline Concha y Toro/Vinhas & Chile & 162,6 \\
\hline San Pedro & Chile & 94,4 \\
\hline Nacional de Chocolates/Alimentos & Colômbia & 234,2 \\
\hline Bavária/Bebidas & Colômbia & 510,0 \\
\hline Êxito/Comércio & Colômbia & $1.472,6$ \\
\hline Caracol/Mídia & Colômbia & 95,7 \\
\hline Café Britt/Alimentos & Costa Rica & 6,5 \\
\hline Supermercados Unidos/Comércio & Costa Rica & 746,1 \\
\hline Bimbo/Alimentos & México & $3.914,0$ \\
\hline Gruma/Alimentos & México & $1.827,7$ \\
\hline Grupo Ind. Saltillo/Autopeças & México & 682,1 \\
\hline José Cuervo/Bebidas & México & 420,6 \\
\hline Femsa/Bebidas & México & $5.293,1$ \\
\hline Grupo Modelo/Bebidas & México & $3.458,1$ \\
\hline Jugos Del Valle/Bebidas & México & 383,1 \\
\hline Corp. Durango/Celulose e Papel & México & 882,1 \\
\hline Cementos Chihuahua/Cimento & México & 330,8 \\
\hline Cemex/Cimento & México & $6.351,5$ \\
\hline Fragua Corporativo/Comércio & México & 550,2 \\
\hline Org. Soriana/Comércio & México & $3.045,4$ \\
\hline Sanborn's/Comércio & México & $1.713,9$ \\
\hline Electra/Comércio & México & $1.661,7$ \\
\hline ALSEA/Comércio & México & 250,4 \\
\hline CIE/Entretenimento & México & 549,2 \\
\hline Consórcio Ara/Engenharia e Construção & México & 403,0 \\
\hline Corp. Geo/Engenharia e Construção & México & 510,9 \\
\hline MABE/Eletrônica & México & $1.663,4$ \\
\hline Corp. San Luis & México & 429,7 \\
\hline Grupo Carso/Mat. de Construção & México & $5.016,1$ \\
\hline TV Azteca/Mídia & México & 641,9 \\
\hline Televisa/Mídia & México & $2.048,7$ \\
\hline Ind. Peñoles/Mineração & México & $1.071,2$ \\
\hline IMSA & México & $2.522,7$ \\
\hline Telmex/Telecomunicações & México & $10.962,0$ \\
\hline América Móvil & México & $5.098,1$ \\
\hline Hilasal Mexicana/Têxtil & México & 41,9 \\
\hline Grupo Posadas/Turismo & México & 367,6 \\
\hline Vitro & México & $2.846,6$ \\
\hline Banco de América Central/Finanças & Nicarágua & 352,4 \\
\hline Banistimo & Panamá & $2.935,5$ \\
\hline Gloria/Alimentos & Peru & 244,6 \\
\hline Minas de Buenaventura/Mineração & Peru & 161,1 \\
\hline Banco Cuscatlán & SAL & $2.151,9$ \\
\hline
\end{tabular}


Anexo 2:

As 100 maiores empresas nacionais - 2002

\begin{tabular}{|c|c|c|c|}
\hline CLASS. & EMPRESA & SEDE & $\begin{array}{c}\text { RECEITA } \\
\text { LÍQUIDA } \\
(\mathrm{R} \$ \text { mil })\end{array}$ \\
\hline 1 & Petróleo Ipiranga & $\mathrm{RJ}$ & 8.939 .267 \\
\hline 2 & TIMAR & RJ & 8.480 .582 \\
\hline 3 & Pão de Açúcar & SP & 7.211 .853 \\
\hline 4 & Embraer & SP & 6.735 .144 \\
\hline 5 & CVRD & $\mathrm{RJ}$ & 6.385 .000 \\
\hline 6 & Brasil Telecom & DF & 6.158 .408 \\
\hline 7 & Varig & RS & 5.251 .006 \\
\hline 8 & Antarctica/CBB & SP & 4.094 .037 \\
\hline 9 & $\mathrm{CSN}$ & RJ & 3.284 .294 \\
\hline 10 & Sadia & $\mathrm{SC}$ & 3.277 .623 \\
\hline 11 & Copene & $\mathrm{BA}$ & 3.137 .996 \\
\hline 12 & Gerdau & RJ & 3.072 .644 \\
\hline 13 & CPFL & SP & 3.056 .270 \\
\hline 14 & Usiminas & MG & 2.942 .383 \\
\hline 15 & Copersucar & SP & 2.780 .277 \\
\hline 16 & TAM & SP & 2.710 .618 \\
\hline 17 & Votorantim & SP & 2.600 .000 \\
\hline 18 & Casas Bahia & SP & 2.528 .787 \\
\hline 19 & Perdigão & SP & 2.424 .864 \\
\hline 20 & Copesul & $\mathrm{RS}$ & 2.359 .645 \\
\hline 21 & TV Globo RJ & $\mathrm{RJ}$ & 2.324 .603 \\
\hline 22 & Sendas & RJ & 2.324 .132 \\
\hline 23 & Ponto Frio & $\mathrm{RJ}$ & 2.093 .365 \\
\hline 24 & CST Tubarão & ES & 1.977 .038 \\
\hline 25 & Ipiranga Dist. & $\mathrm{RS}$ & 1.926 .346 \\
\hline 26 & Norberto Odebrecht & RJ & 1.888 .344 \\
\hline 27 & OPP Química & BA & 1.759 .578 \\
\hline 28 & Cosipa & SP & 1.712 .172 \\
\hline 29 & Atacadão & SP & 1.674 .374 \\
\hline 30 & VCP & SP & 1.541 .562 \\
\hline 31 & Coelba & $\mathrm{BA}$ & 1.516 .697 \\
\hline 32 & Coamo & PR & 1.490 .299 \\
\hline 33 & Petroquímica União & SP & 1.446 .589 \\
\hline 34 & Rio Branco & SP & 1.409 .077 \\
\hline 35 & Cisa & ES & 1.383 .576 \\
\hline 36 & Lojas Americanas & RJ & 1.358 .628 \\
\hline 37 & Bertin & SP & 1.349 .644 \\
\hline 38 & $\mathrm{BCP}$ & SP & 1.324 .321 \\
\hline 39 & Martins & MG & 1.320 .333 \\
\hline 40 & Acesita & MG & 1.312 .368 \\
\hline 41 & C R Almeida Eng & RJ & 1.307 .674 \\
\hline 42 & Camargo Corrêa & SP & 1.205 .187 \\
\hline 43 & Aracruz Celulose & ES & 1.180 .593 \\
\hline 44 & Editora Abril & SP & 1.121 .094 \\
\hline 45 & Albrás & $\mathrm{PA}$ & 1.094 .637 \\
\hline 46 & Ultragaz & SP & 1.071 .517 \\
\hline 47 & Variglog & SP & 1.064 .876 \\
\hline 48 & Vicunha & $\mathrm{CE}$ & 1.044 .910 \\
\hline 49 & Sé & SP & 1.043 .637 \\
\hline 50 & Açominas & MG & 1.027258 \\
\hline 51 & CBA & SP & 1.094 .422 \\
\hline 52 & Celpe & $\mathrm{PE}$ & 1.002 .675 \\
\hline 53 & Suzano & SP & 998.668 \\
\hline 54 & Trikem & $\mathrm{BA}$ & 985.056 \\
\hline 55 & Ale & MG & 970.073 \\
\hline 56 & WEG & $\mathrm{SC}$ & 955.183 \\
\hline 57 & Caraíba Metais & $\mathrm{BA}$ & 946.153 \\
\hline 58 & MBR & RJ & 937.900 \\
\hline
\end{tabular}




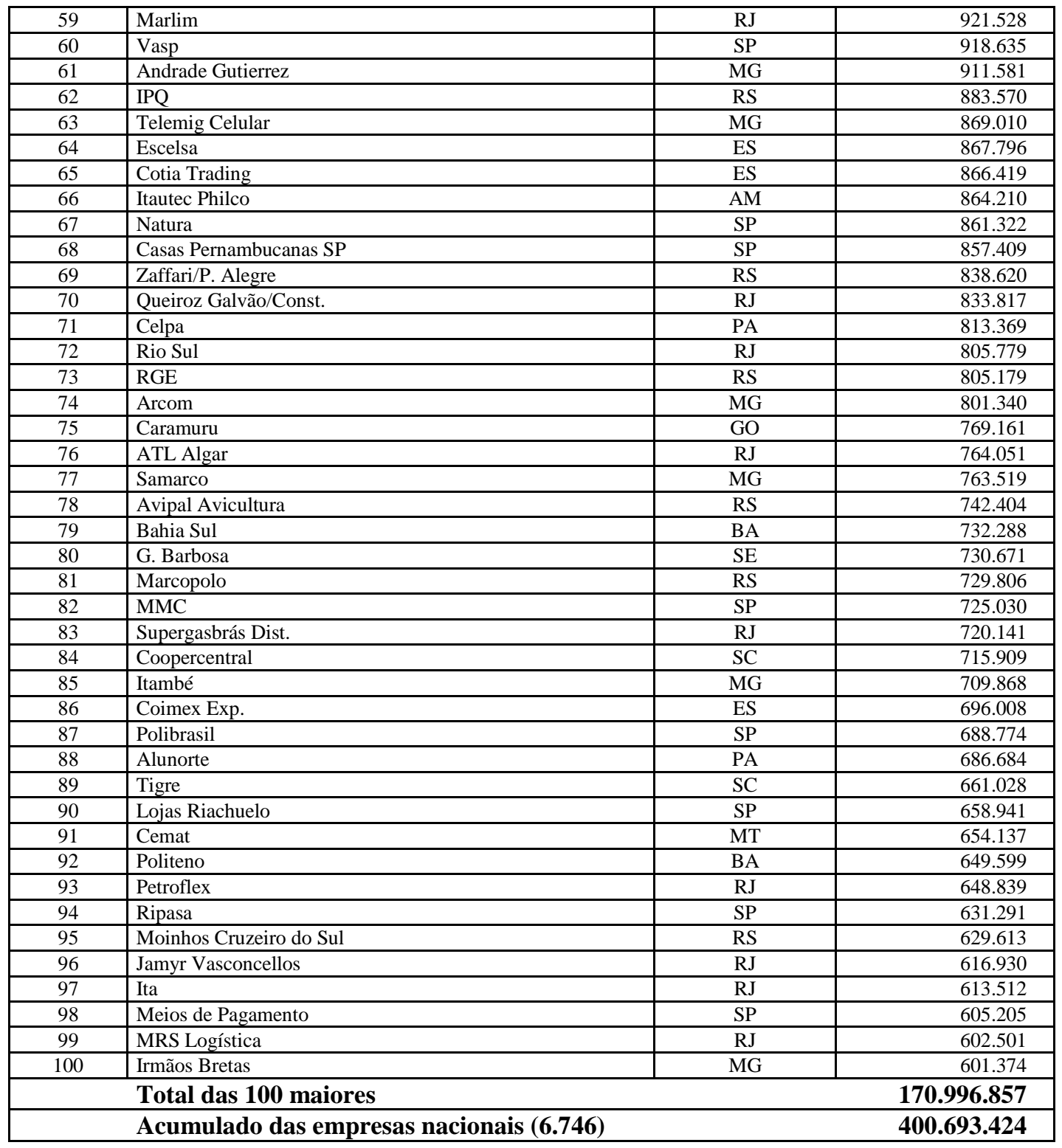




\section{Anexo 3:}

As 100 maiores empresas estrangeiras - 2002

\begin{tabular}{|c|c|c|c|}
\hline CLASS. & EMPRESA & SEDE & $\begin{array}{c}\text { RECEITA } \\
\text { LÍQUIDA } \\
(\mathrm{R} \$ \text { mil }) \\
\end{array}$ \\
\hline 1 & Volkswagen & SP & 10.200 .000 \\
\hline 2 & Carrefour & SP & 9.236 .683 \\
\hline 3 & Telefônica & SP & 8.983 .078 \\
\hline 4 & Shell & RJ & 8.906 .456 \\
\hline 5 & Embratel & RJ & 7.270 .209 \\
\hline 6 & Esso & RJ & 7.117 .000 \\
\hline 7 & General Motors & $\mathrm{SP}$ & 7.013 .430 \\
\hline 8 & Fiat & MG & 6.440 .949 \\
\hline 9 & Texaco & RJ & 6.229 .005 \\
\hline 10 & Eletropaulo & SP & 5.887 .944 \\
\hline 11 & Bunge Alimentos & $\mathrm{SC}$ & 5.357 .474 \\
\hline 12 & Ford Motor & SP & 4.300 .000 \\
\hline 13 & Cargill & $\mathrm{SP}$ & 4.225 .993 \\
\hline 14 & Daimler Chrysler & SP & 4.138 .463 \\
\hline 15 & Light & RJ & 3.829 .049 \\
\hline 16 & Gessy Lever & SP & 3.589 .178 \\
\hline 17 & Sonae & $\mathrm{RS}$ & 3.411 .419 \\
\hline 18 & Nestlé & SP & 3.295 .822 \\
\hline 19 & Siemens & $\mathrm{SP}$ & 3.093 .219 \\
\hline 20 & Telesp Celular & $\mathrm{SP}$ & 2.946 .234 \\
\hline 21 & Ericsson & SP & 2.551 .997 \\
\hline 22 & Bandeirante Energia & SP & 2.521 .721 \\
\hline 23 & Basf & SP & 2.505 .620 \\
\hline 24 & Nokia & SP & 2.211 .068 \\
\hline 25 & Avon & SP & 2.200 .000 \\
\hline 26 & Souza Cruz & RJ & 2.166 .900 \\
\hline 27 & Bunge Fertilizantes & SP & 2.141 .236 \\
\hline 28 & Xerox Com & ES & 2.100 .000 \\
\hline 29 & Makro & SP & 2.098 .764 \\
\hline 30 & Tractebel Energia & $\mathrm{SC}$ & 2.083 .025 \\
\hline 31 & Honda AM & $\mathrm{AM}$ & 1.981 .661 \\
\hline 32 & Coinbra & SP & 1.944 .701 \\
\hline 33 & Agip Distribuidora & $\mathrm{SP}$ & 1.919 .981 \\
\hline 34 & NEC & SP & 1.695 .724 \\
\hline 35 & Bompreço Supermercados & $\mathrm{PE}$ & 1.686 .541 \\
\hline 36 & Alcoa & MG & 1.626 .212 \\
\hline 37 & Multibrás & SP & 1.600 .594 \\
\hline 38 & MacDonald's & SP & 1.600 .000 \\
\hline 39 & Elektro & $\mathrm{SP}$ & 1.572 .039 \\
\hline 40 & Telerj Celular & RJ & 1.496 .552 \\
\hline 41 & Wal Mart & SP & 1.482 .899 \\
\hline 42 & Renault & $\begin{array}{l}\mathrm{PR} \\
\end{array}$ & 1.424 .435 \\
\hline 43 & Agip do Brasil & SP & 1.420 .912 \\
\hline 44 & Cerj & RJ & 1.392 .067 \\
\hline 45 & Bayer & SP & 1.363 .001 \\
\hline 46 & AES & RS & 1.325 .320 \\
\hline 47 & Scania Latin America & $\mathrm{SP}$ & 1.322 .375 \\
\hline 48 & Rhodia & SP & 1.288 .794 \\
\hline 49 & Belgo Mineira & MG & 1.282 .348 \\
\hline 50 & Pirelli Pneus & SP & 1.265 .021 \\
\hline 51 & Hewlett-Packard & SP & 1.233 .755 \\
\hline 52 & Seara & $\mathrm{SC}$ & 1.199 .575 \\
\hline 53 & Alcatel Telecoms & $\mathrm{SP}$ & 1.182 .721 \\
\hline 54 & Nortel Networks & SP & 1.150 .000 \\
\hline 55 & $\mathrm{ABB}$ & SP & 1.134 .982 \\
\hline 56 & Parmalat & SP & 1.127 .027 \\
\hline 57 & Du Pont & SP & 1.074 .126 \\
\hline 58 & Alcan & $\mathrm{SP}$ & 1.066 .520 \\
\hline
\end{tabular}




\begin{tabular}{|c|c|c|c|}
\hline 59 & $3 \mathrm{M}$ & SP & 1.034 .000 \\
\hline 60 & Bompreço BA & $\mathrm{BA}$ & 1.013 .086 \\
\hline 61 & Goodyear & $\mathrm{SP}$ & 1.000 .000 \\
\hline 62 & Volvo & PR & 915.000 \\
\hline 63 & Coca Cola Spal & SP & 901.999 \\
\hline 64 & Coelce & $\mathrm{CE}$ & 899.522 \\
\hline 65 & Kodak & SP & 893.836 \\
\hline 66 & Philips AM & $\mathrm{AM}$ & 869.965 \\
\hline 67 & Comgás & SP & 869.194 \\
\hline 68 & Dow & SP & 867.057 \\
\hline 69 & Frangosul & $\mathrm{RS}$ & 854.940 \\
\hline 70 & White Martins Gases & $\mathrm{RJ}$ & 843.708 \\
\hline 71 & Microsoft & SP & 842.000 \\
\hline 72 & Celular CRT & $\mathrm{RS}$ & 829.461 \\
\hline 73 & Universal Leaf & $\mathrm{RS}$ & 828.777 \\
\hline 74 & Embraco & $\mathrm{SC}$ & 827.950 \\
\hline 75 & Dow AgroSciences & SP & 809.981 \\
\hline 76 & Clariant & SP & 794.181 \\
\hline 77 & Electrolux & $\mathrm{PR}$ & 766.648 \\
\hline 78 & Visteon & SP & 758.647 \\
\hline 79 & Roche & SP & 753.291 \\
\hline 80 & Sabbá & $\mathrm{AM}$ & 750.757 \\
\hline 81 & Fleischmann Royal & PR & 743.509 \\
\hline 82 & AES Tietê & $\mathrm{SP}$ & 738.299 \\
\hline 83 & Matrix Internet & $\mathrm{SC}$ & 736.369 \\
\hline 84 & Rhodia Ster Fibras & SP & 720.482 \\
\hline 85 & Belgo Bekaert & MG & 718.599 \\
\hline 86 & TRW Automotive & SP & 711.625 \\
\hline 87 & Holcim & $\mathrm{SP}$ & 708.445 \\
\hline 88 & Peugeot Citroen & $\mathrm{RJ}$ & 695.739 \\
\hline 89 & Ultrafertil & SP & 694.480 \\
\hline 90 & $\mathrm{~V} \& \mathrm{M}$ & MG & 692.071 \\
\hline 91 & Cenibra & MG & 686.114 \\
\hline 92 & Samsung AM & $\mathrm{AM}$ & 673.569 \\
\hline 93 & Saint-Gobain Vidros & $\mathrm{SP}$ & 660.639 \\
\hline 94 & Kaiser Brasil & $\mathrm{SP}$ & 652.854 \\
\hline 95 & Eaton & $\mathrm{SP}$ & 639.212 \\
\hline 96 & Kraft Foods & PR & 638.707 \\
\hline 97 & Confab Indl & SP & 632.696 \\
\hline 98 & Novartis & SP & 631.350 \\
\hline 99 & Chapecó Alimentos & $\mathrm{SC}$ & 627.478 \\
\hline 100 & Mahle Metal Leve & $\mathrm{SP}$ & 622.141 \\
\hline \multicolumn{3}{|c|}{ Total das 100 maiores } & 210.460 .088 \\
\hline \multicolumn{3}{|c|}{$\begin{array}{l}\text { Acumulado das empresas estrangeiras } \\
(\mathbf{8 8 5})\end{array}$} & 288.267 .962 \\
\hline
\end{tabular}




\section{Anexo 4:}

AS 100 MAIORES EMPRESAS ESTATAIS - 2002

\begin{tabular}{|c|c|c|c|}
\hline CLASS. & EMPRESA & SEDE & $\begin{array}{c}\text { RECEITA } \\
\text { LÍQUIDA } \\
(\mathrm{R} \$ \text { mil })\end{array}$ \\
\hline 1 & Petrobrás & RJ & 49.092 .907 \\
\hline 2 & BR Distribuidora & $\mathrm{RJ}$ & 16.120 .090 \\
\hline 3 & Furnas & $\mathrm{RJ}$ & 9.252 .455 \\
\hline 4 & Cemig & MG & 4.712 .884 \\
\hline 5 & Correios & DF & 4.546 .890 \\
\hline 6 & Sabesp & SP & 3.434 .767 \\
\hline 7 & Chesf & $\mathrm{PE}$ & 2.960 .343 \\
\hline 8 & Cesp & SP & 2.113 .349 \\
\hline 9 & Eletronorte & DF & 1.620 .935 \\
\hline 10 & Celesc & SC & 1.442 .001 \\
\hline 11 & Eletrosul & $\mathrm{SC}$ & 1.344 .904 \\
\hline 12 & Infraero & DF & 1.287 .720 \\
\hline 13 & Cedae & RJ & 1.272 .006 \\
\hline 14 & Copel Distribuição & PR & 1.127 .426 \\
\hline 15 & Transpetro & RJ & 1.077 .605 \\
\hline 16 & CEEE & $\mathrm{RS}$ & 1.032 .207 \\
\hline 17 & Copel Cia. Paranaense & PR & 1.023 .476 \\
\hline 18 & Celg & $\mathrm{GO}$ & 1.009 .629 \\
\hline 19 & Copasa MG & MG & 817.339 \\
\hline 20 & Ferteco & RJ & 784.833 \\
\hline 21 & Sanepar & PR & 737.125 \\
\hline 22 & Serpro & DF & 731.364 \\
\hline 23 & Eletronuclear & RJ & 683.273 \\
\hline 24 & Embrapa & DF & 647.280 \\
\hline 25 & CEB & DF & 646.258 \\
\hline 26 & Manaus Energia & $\mathrm{AM}$ & 627.498 \\
\hline 27 & Metrô SP & SP & 548.810 \\
\hline 28 & Corsan & $\mathrm{RS}$ & 517.617 \\
\hline 29 & CPTM & SP & 514.871 \\
\hline 30 & EMAE & SP & 479.093 \\
\hline 31 & Conab & DF & 456.431 \\
\hline 32 & Copel Geração & PR & 449.414 \\
\hline 33 & CTEEP & SP & 421.398 \\
\hline 34 & Embasa & $\mathrm{BA}$ & 373.283 \\
\hline 35 & Dataprev & DF & 343.266 \\
\hline 36 & TBG & RJ & 343.064 \\
\hline 37 & Valesul & RJ & 302.655 \\
\hline 38 & Casan & $\mathrm{SC}$ & 292.256 \\
\hline 39 & Caesb & DF & 285.618 \\
\hline 40 & CBTU & RJ & 285.334 \\
\hline 41 & Comlurb & $\mathrm{RJ}$ & 282.164 \\
\hline 42 & Cobra & RJ & 266.815 \\
\hline 43 & Bahiagás & $\mathrm{BA}$ & 265.467 \\
\hline 44 & Sulgás & RS & 257.828 \\
\hline 45 & Saneago & $\mathrm{GO}$ & 253.569 \\
\hline 46 & Compesa & $\mathrm{PE}$ & 252.001 \\
\hline 47 & Ceal & $\mathrm{AL}$ & 249.873 \\
\hline 48 & Codesp & SP & 240.205 \\
\hline 49 & Cet & SP & 236.442 \\
\hline 50 & Ebal & BA & 232.951 \\
\hline 51 & N S Conceição & $\mathrm{RS}$ & 223.766 \\
\hline 52 & HCPA & $\mathrm{RS}$ & 221.890 \\
\hline 53 & Cepisa & $\mathrm{PI}$ & 219.533 \\
\hline 54 & Codevasf & DF & 219.335 \\
\hline 55 & Ceron & $\mathrm{RO}$ & 210.351 \\
\hline 56 & Prodesp & SP & 195.995 \\
\hline 57 & CGTEE & $\mathrm{RS}$ & 195.943 \\
\hline 58 & Cagece & $\mathrm{CE}$ & 193.362 \\
\hline
\end{tabular}




\begin{tabular}{|c|c|c|c|}
\hline 59 & Dersa & SP & 186.789 \\
\hline 60 & Casa da Moeda & RJ & 173.373 \\
\hline 61 & INB & $\mathrm{DF}$ & 169.051 \\
\hline 62 & Cesan & ES & 166.025 \\
\hline 63 & Sanasa & SP & 165.891 \\
\hline 64 & Cetesb & SP & 154.096 \\
\hline 65 & Cagepa & $\mathrm{PB}$ & 151.213 \\
\hline 66 & CPRM & DF & 141.555 \\
\hline 67 & SPTrans & SP & 138.206 \\
\hline 68 & Ceam & $\mathrm{AM}$ & 137.905 \\
\hline 69 & Caema & MA & 115.995 \\
\hline 70 & Imesp/Diário Oficial & SP & 113.931 \\
\hline 71 & Gasmig & MG & 111.173 \\
\hline 72 & Prodam São Paulo & SP & 109.443 \\
\hline 73 & Metrô DF & DF & 109.148 \\
\hline 74 & Sercomtel & PR & 106.395 \\
\hline 75 & Limpurb & $\mathrm{BA}$ & 106.145 \\
\hline 76 & Caem & RN & 102.352 \\
\hline 77 & Cohab SP & SP & 97.037 \\
\hline 78 & Cosanpa & PA & 95.894 \\
\hline 79 & Epagri & $\mathrm{SC}$ & 95.144 \\
\hline 80 & Municipal de Vigilância & $\mathrm{RJ}$ & 94.357 \\
\hline 81 & Deso & SE & 92.834 \\
\hline 82 & SCGás & $\mathrm{SC}$ & 90.494 \\
\hline 83 & Procergs & $\mathrm{RS}$ & 86.934 \\
\hline 84 & Agespisa & PI & 86.325 \\
\hline 85 & Flumitrens & RJ & 85.256 \\
\hline 86 & IPT & SP & 80.776 \\
\hline 87 & ONS & DF & 76.192 \\
\hline 88 & Comurg & GO & 75.610 \\
\hline 89 & Emater PR & PR & 75.207 \\
\hline 90 & BVEnergia & $\mathrm{RR}$ & 73.667 \\
\hline 91 & Eletroacre & $\mathrm{AC}$ & 72.926 \\
\hline 92 & Sanesul & MS & 71.398 \\
\hline 93 & Emater MG & MG & 71.121 \\
\hline 94 & Copergás & $\mathrm{PE}$ & 69.275 \\
\hline 95 & Prodemge & MG & 66.890 \\
\hline 96 & Cidasc & $\mathrm{SC}$ & 65.736 \\
\hline 97 & Cristo Redentor & $\mathrm{RS}$ & 63.607 \\
\hline 98 & Cea & $\mathrm{AP}$ & 63.510 \\
\hline 99 & MGS & MG & 61.220 \\
\hline 100 & Terracap & DF & 60.203 \\
\hline \multicolumn{3}{|c|}{ Total das 100 maiores } & 124.311 .363 \\
\hline \multicolumn{3}{|c|}{ Acumulado das empresas estatais (358) } & 127.488 .881 \\
\hline
\end{tabular}




\section{Anexo 5:}

\section{CRONOLOGIA DE TRANSAÇÕES ENTRE BANCOS NO BRASIL, DESDE A DÉCADA DE 1960 ATÉ 2003}

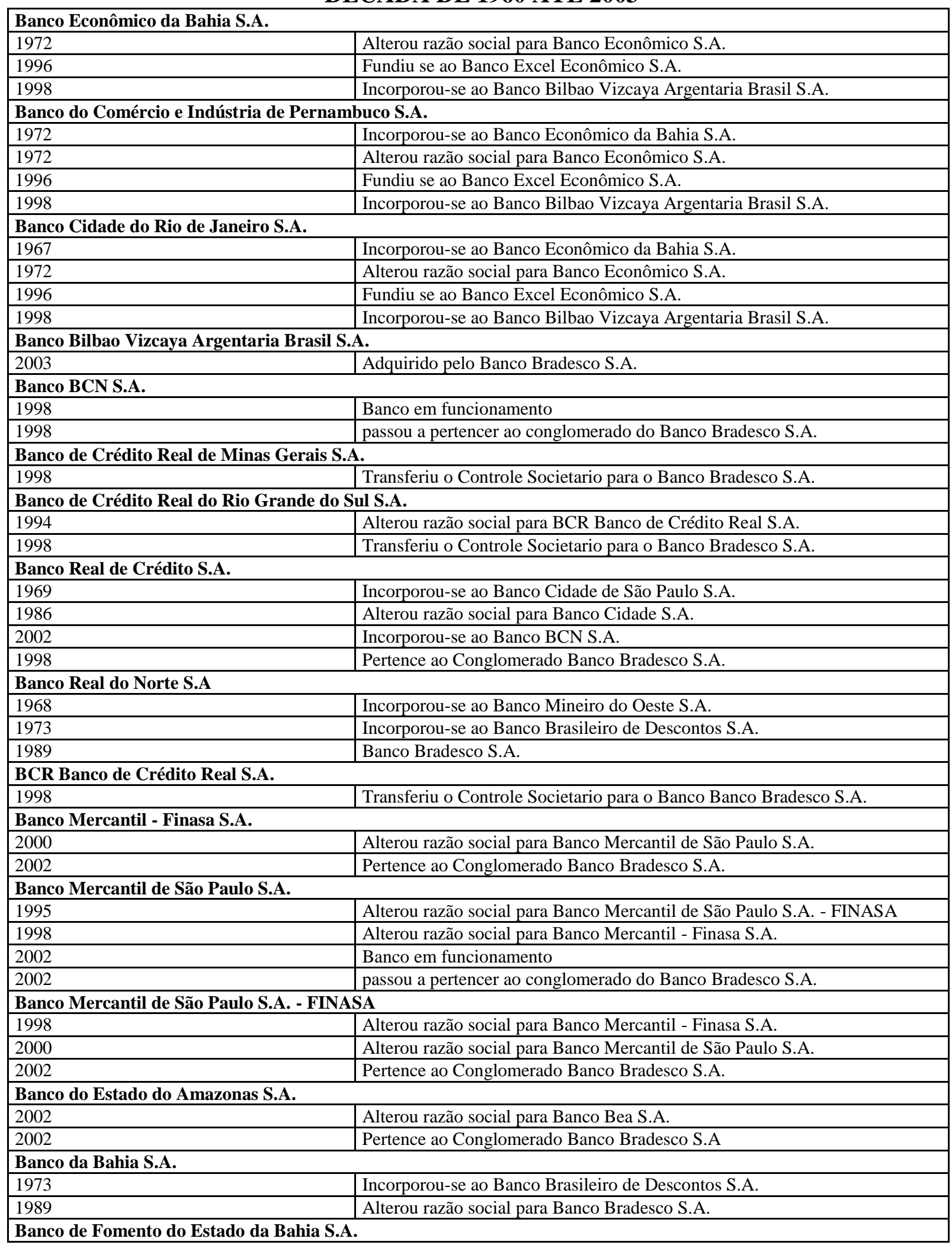




\begin{tabular}{|c|c|}
\hline 1965 & Alterou razão social para Banco do Estado da Bahia S.A. \\
\hline 1999 & Alterou razão social para Banco Baneb S.A. \\
\hline 1999 & Pertence ao Conglomerado Banco Bradesco S.A. \\
\hline \multicolumn{2}{|c|}{ Banco dos Importadores e Exportadores do Ceará S.A. } \\
\hline 1972 & Incorporou-se ao Banco Brasileiro de Descontos S.A. \\
\hline 1989 & Alterou razão social para Banco Bradesco S.A. \\
\hline \multicolumn{2}{|c|}{ Banco de Crédito Nacional da Guanabara S.A. } \\
\hline 1968 & Incorporou-se ao Banco de Credito Nacional S.A. \\
\hline 2001 & Alterou razão social para Banco BCN S.A. \\
\hline 1998 & Pertence ao Conglomerado Banco Bradesco S.A. \\
\hline \multicolumn{2}{|c|}{ Banco de Crédito Real do Rio Grande do Sul S.A. } \\
\hline 1994 & Alterou razão social para BCR Banco de Crédito Real S.A. \\
\hline 1998 & Transferiu o Controle Societario para o Banco Bradesco S.A. \\
\hline \multicolumn{2}{|c|}{ Banco Cidade de São Paulo S.A } \\
\hline 1986 & Alterou razão social para Banco Cidade S.A. \\
\hline 2002 & Incorporou-se ao Banco BCN S.A. \\
\hline 1998 & Pertence ao Conglomerado Banco Bradesco S.A. \\
\hline \multicolumn{2}{|c|}{ Banco Econômico de São Paulo S.A. } \\
\hline 1975 & Incorporou-se ao Banco Lavra S.A. \\
\hline 1982 & Alterou razão social para Banco Valbrás S.A. \\
\hline 1984 & Alterou razão social para Digibanco - Banco Digital S.A. \\
\hline 1988 & Alterou razão social para Digibanco - Banco Comercial S.A. \\
\hline 1989 & Alterou razão social para Banco Digibanco S.A. \\
\hline 1989 & Incorporou-se ao Banco Pontual S.A. \\
\hline 1998 & Transferiu o Controle Societario para o Banco Bradesco S.A. \\
\hline \multicolumn{2}{|c|}{ Banco Econômico de São Paulo SCRL } \\
\hline 1967 & Fundiu se ao Banco Econômico de São Paulo S.A. \\
\hline 1975 & Incorporou-se ao Banco Lavra S.A. \\
\hline 1982 & Alterou razão social para Banco Valbrás S.A. \\
\hline 1984 & Alterou razão social para Digibanco - Banco Digital S.A. \\
\hline 1988 & Alterou razão social para Digibanco - Banco Comercial S.A. \\
\hline 1989 & Alterou razão social para Banco Digibanco S.A. \\
\hline 1989 & Incorporou-se ao Banco Pontual S.A. \\
\hline 1998 & Transferiu o Controle Societario para o Banco Bradesco S.A. \\
\hline \multicolumn{2}{|c|}{ Banco Italbrás de São Paulo S.A. } \\
\hline 1967 & Fundiu se ao Banco Econômico de São Paulo S.A. \\
\hline 1975 & Incorporou-se ao Banco Lavra S.A. \\
\hline 1982 & Alterou razão social para Banco Valbrás S.A. \\
\hline 1984 & Alterou razão social para Digibanco - Banco Digital S.A. \\
\hline 1988 & Alterou razão social para Digibanco - Banco Comercial S.A. \\
\hline 1989 & Alterou razão social para Banco Digibanco S.A. \\
\hline 1989 & Incorporou-se ao Banco Pontual S.A \\
\hline 1998 & Transferiu o Controle Societario para o Banco Bradesco S.A. \\
\hline \multicolumn{2}{|c|}{ Banco Mercantil de São Paulo S.A. } \\
\hline 1995 & Alterou razão social para Banco Mercantil de São Paulo S.A. - FINASA \\
\hline 1998 & Alterou razão social para Banco Mercantil - Finasa S.A \\
\hline 2000 & Alterou razão social para Banco Mercantil de São Paulo S.A. \\
\hline 2002 & Pertence ao Conglomerado Banco Bradesco S.A. \\
\hline \multicolumn{2}{|c|}{ Banco Bamerindus de São Paulo S.A. } \\
\hline 1971 & Incorporou-se ao Banco Mercantil e Industrial do Paraná S.A. \\
\hline 1971 & Alterou razão social para Banco Nacional do Comércio de São Paulo S.A. \\
\hline 1975 & Incorporou-se ao Banco Bamerindus do Brasil S.A. \\
\hline 1997 & Alterou razão social para Banco HSBC Bamerindus S.A. \\
\hline 1999 & Alterou razão social para HSBC Bank Brasil S.A. - Banco Múltiplo \\
\hline \multicolumn{2}{|c|}{ Banco Bamerindus do Nordeste S.A } \\
\hline 1972 & Incorporou-se ao Banco Bamerindus do Brasil S.A. \\
\hline 1997 & Alterou razão social para Banco HSBC Bamerindus S.A. \\
\hline 1999 & Alterou razão social para HSBC Bank Brasil S.A. - Banco Múltiplo \\
\hline
\end{tabular}




\begin{tabular}{|c|c|}
\hline 1999 & Alterou razão social para HSBC Bank Brasil S.A. - Banco Múltiplo \\
\hline \multicolumn{2}{|c|}{ Banco Real do Progresso S.A. } \\
\hline 1968 & Incorporou-se ao Banco Mercantil e Industrial de S. Paulo S.A. \\
\hline 1970 & Alterou razão social para Banco Bamerindus de São Paulo S.A. \\
\hline 1971 & Incorporou-se ao Banco Mercantil e Industrial do Paraná S. \\
\hline 1971 & Alterou razão social para Banco Nacional do Comércio de São Paulo S.A. \\
\hline 1975 & Incorporou-se ao Banco Bamerindus do Brasil S.A. \\
\hline 1997 & Alterou razão social para Banco HSBC Bamerindus S.A. \\
\hline 1999 & Alterou razão social para HSBC Bank Brasil S.A. - Banco Múltiplo \\
\hline \multicolumn{2}{|c|}{ Banco Agro-mercantil de Alagôas S.A. } \\
\hline 1967 & Alterou razão social para Banco Agro-mercantil S.A. \\
\hline 1968 & Incorporou-se ao Banco de Crédito da Bahia S.A. \\
\hline 1971 & Fundiu se ao Banco Bamerindus do Nordeste S.A \\
\hline 1972 & Incorporou-se ao Banco Bamerindus do Brasil S.A. \\
\hline 1997 & Alterou razão social para Banco HSBC Bamerindus S.A. \\
\hline 1999 & Alterou razão social para HSBC Bank Brasil S.A. - Banco Múltiplo \\
\hline \multicolumn{2}{|c|}{ Banco Agro-mercantil S.A. } \\
\hline 1968 & Incorporou-se ao Banco de Crédito da Bahia S.A. \\
\hline 1971 & Fundiu se ao Banco Bamerindus do Nordeste S.A. \\
\hline 1972 & Incorporou-se ao Banco Bamerindus do Brasil S.A. \\
\hline 1997 & Alterou razão social para Banco HSBC Bamerindus S.A. \\
\hline 1999 & Alterou razão social para HSBC Bank Brasil S.A. - Banco Múltiplo \\
\hline \multicolumn{2}{|c|}{ Banco da Indústria e Comércio da Guanabara S.A. } \\
\hline 1968 & Incorporou-se ao Banco Mercantil e Industrial do Rio Grande do Sul S.A. \\
\hline 1970 & Incorporou-se ao Banco Mercantil e Industrial do Paraná S.A. \\
\hline 1971 & Alterou razão social para Banco Nacional do Comércio de São Paulo S.A. \\
\hline 1975 & Incorporou-se ao Banco Bamerindus do Brasil S.A. \\
\hline 1997 & Alterou razão social para Banco HSBC Bamerindus S.A. \\
\hline 1999 & Alterou razão social para HSBC Bank Brasil S.A. - Banco Múltiplo \\
\hline \multicolumn{2}{|c|}{ Banco Mercantil e Industrial do Rio Grande do Sul S.A. } \\
\hline 1970 & Incorporou-se ao Banco Mercantil e Industrial do Paraná S.A. \\
\hline 1971 & Alterou razão social para Banco Nacional do Comércio de São Paulo S.A. \\
\hline 1975 & Incorporou-se ao Banco Bamerindus do Brasil S.A \\
\hline 1997 & Alterou razão social para Banco HSBC Bamerindus S.A. \\
\hline 1999 & Alterou razão social para HSBC Bank Brasil S.A. - Banco Múltiplo \\
\hline \multicolumn{2}{|c|}{ Banco Mercantil e Industrial de Santa Catarina S.A. } \\
\hline 1971 & Incorporou-se ao Banco Banco Mercantil e Industrial do Paraná S.A. \\
\hline 1971 & Alterou razão social para Banco Nacional do Comércio de São Paulo S.A. \\
\hline 1975 & Incorporou-se ao Banco Bamerindus do Brasil S.A. \\
\hline 1997 & Alterou razão social para Banco HSBC Bamerindus S.A. \\
\hline 1999 & Alterou razão social para HSBC Bank Brasil S.A. - Banco Múltiplo \\
\hline \multicolumn{2}{|c|}{ Banco Real Unido S.A. } \\
\hline 1968 & Incorporou-se ao Banco Banco de Minas Gerais S.A. \\
\hline 1973 & Incorporou-se ao Banco Real S.A. \\
\hline 1995 & Incorporou-se ao Banco ABN Amro Bank \\
\hline 1995 & Alterou razão social para Banco ABN Amro S.A. \\
\hline 1999 & Alterou razão social para Banco ABN AMRO Real S.A. \\
\hline \multicolumn{2}{|c|}{ Banco Mercantil da Guanabara S.A. } \\
\hline 1967 & Incorporou-se ao Banco de Minas Gerais S.A \\
\hline 1973 & Incorporou-se ao Banco Real S.A. \\
\hline 1995 & Incorporou-se ao Banco ABN Amro Bank \\
\hline 1995 & Alterou razão social para Banco ABN Amro S.A. \\
\hline 1999 & Alterou razão social para Banco ABN AMRO Real S.A. \\
\hline \multicolumn{2}{|c|}{ Banco Comercial e de Investimentos Sudameris S/A } \\
\hline 1998 & Incorporou-se ao Banco Sudameris Brasil S.A. \\
\hline \multicolumn{2}{|c|}{ Banco Bahiano da Produção S.A. } \\
\hline 1970 & Fundiu se ao Banco Comercial da Produção S.A. \\
\hline 1973 & Incorporou-se ao Banco Comercial e de Investimentos Sudameris S/A \\
\hline 1998 & Banco Sudameris Brasil S.A. \\
\hline
\end{tabular}




\begin{tabular}{|c|c|}
\hline \multicolumn{2}{|c|}{ Banco Sudameris Brasil S/A } \\
\hline 2003 & Adquirido pelo ABN AMRO Real S.A. \\
\hline \multicolumn{2}{|c|}{ Banco Metropolitano de Crédito Mercantil S.A. } \\
\hline 1963 & Incorporou-se ao Banco do Estado do Rio de Janeiro S.A. \\
\hline 1997 & Alterou razão social para Banco Banerj S.A. \\
\hline 1997 & Pertence ao Conglomerado Banco Itaú S.A. \\
\hline \multicolumn{2}{|c|}{ Banco Banerj S.A. } \\
\hline 1997 & Banco em funcionamento \\
\hline 1997 & passou a pertencer ao conglomerado do Banco Itaú S.A. \\
\hline \multicolumn{2}{|c|}{ Banco Bemge S.A. } \\
\hline 1998 & Banco em funcionamento \\
\hline 1998 & passou a pertencer ao conglomerado do Banco Itaú S.A. \\
\hline \multicolumn{2}{|c|}{ Banco Beg S.A. } \\
\hline 2001 & Banco em funcionamento \\
\hline 2001 & passou a pertencer ao conglomerado do Banco Itaú S.A. \\
\hline \multicolumn{2}{|c|}{ Banco Bea S.A. } \\
\hline 2002 & Banco em funcionamento \\
\hline 2002 & passou a pertencer ao conglomerado do Banco Itaú S.A \\
\hline \multicolumn{2}{|c|}{ Banco do Estado de Minas Gerais S.A. } \\
\hline 1998 & Alterou razão social para Banco Bemge S.A. \\
\hline 1998 & Pertence ao Conglomerado Banco Itaú S.A. \\
\hline \multicolumn{2}{|c|}{ Banco Comercial e Industrial do Estado do Rio de Janeiro S.A } \\
\hline 1966 & Incorporou-se ao Banco Andrade Arnaud S.A. \\
\hline 1972 & Fundiu se ao Banco Halles S.A. \\
\hline 1974 & Incorporou-se ao Banco do Estado da Guanabara S.A. \\
\hline 1976 & Fundiu se ao Banco do Estado do Rio de Janeiro S.A. \\
\hline 1997 & Alterou razão social para Banco Banerj S.A. \\
\hline 1997 & Pertence ao Conglomerado Banco Itaú S.A. \\
\hline \multicolumn{2}{|c|}{ Banco Auxiliar da Guanabara S.A. } \\
\hline 1967 & Incorporou-se ao Banco Bordallo Brenha S.A. \\
\hline 1970 & Incorporou-se ao Banco Andrade Arnaud S.A \\
\hline 1972 & Fundiu se ao Banco Halles S.A. \\
\hline 1974 & Incorporou-se ao Banco do Estado da Guanabara S.A. \\
\hline 1976 & Fundiu se ao Banco do Estado do Rio de Janeiro S.A. \\
\hline 1997 & Alterou razão social para Banco Banerj S.A. \\
\hline 1997 & Pertence ao Conglomerado Banco Itaú S.A. \\
\hline \multicolumn{2}{|c|}{ Banco Econômico Nacional S.A. } \\
\hline 1966 & Incorporou-se ao Banco Português do Brasil S.A. \\
\hline 1973 & Incorporou-se ao Banco Itaú América S.A \\
\hline 1973 & Alterou razão social para Banco Itaú S.A. \\
\hline \multicolumn{2}{|c|}{ Banco do Estado da Guanabara S.A. } \\
\hline 1976 & Fundiu se ao Banco do Estado do Rio de Janeiro S.A \\
\hline 1997 & Alterou razão social para Banco Banerj S.A. \\
\hline 1997 & Pertence ao Conglomerado Banco Itaú S.A. \\
\hline \multicolumn{2}{|c|}{ Banco Aliança do Rio Grande do Sul S.A. } \\
\hline 1967 & Incorporou-se ao Banco do Estado do Rio de Janeiro S.A. \\
\hline 1997 & Alterou razão social para Banco Banerj S.A. \\
\hline 1997 & Pertence ao Conglomerado Banco Itaú S.A. \\
\hline \multicolumn{2}{|c|}{ Banco da Metrópole de São Paulo S.A. } \\
\hline 1948 & Alterou razão social para Banco Francês e Brasileiro S.A \\
\hline 1995 & Esta sob controle acionário do Banco Itaú S.A. \\
\hline \multicolumn{2}{|c|}{ Banco Nacional do Espírito Santo S.A. } \\
\hline 1972 & Fundiu se ao Banco Nacional S.A. \\
\hline 1995 & Incorporou-se ao Banco UNIBANCO - União de Bancos Brasileiros S.A. \\
\hline \multicolumn{2}{|c|}{ Banco Comercial de Minas Gerais S.A. } \\
\hline 1972 & Fundiu se ao Banco Nacional S.A. \\
\hline 1995 & Incorporou-se ao Banco UNIBANCO - União de Bancos Brasileiros S.A. \\
\hline \multicolumn{2}{|c|}{ Banco do Comércio e Indústria de Minas Gerais S.A. } \\
\hline 1974 & Incorporou-se ao Banco Nacional S.A. \\
\hline
\end{tabular}




\begin{tabular}{|c|c|}
\hline 1995 & Incorporou-se ao Banco UNIBANCO - União de Bancos Brasileiros S.A. \\
\hline \multicolumn{2}{|c|}{ Banco Econômico de Minas Gerais S.A. } \\
\hline 1973 & Incorporou-se ao Banco Mineiro S.A. \\
\hline 1981 & Incorporou-se ao Banco UNIBANCO - União de Bancos Brasileiros S.A \\
\hline \multicolumn{2}{|c|}{ Banco da Grande São Paulo S.A. } \\
\hline 1971 & Incorporou-se ao Banco Nacional de Minas Gerais S.A. \\
\hline 1972 & Fundiu se ao Banco Nacional S.A. \\
\hline 1995 & Incorporou-se ao Banco UNIBANCO - União de Bancos Brasileiros S.A. \\
\hline \multicolumn{2}{|c|}{ Banco Noroeste do Estado de São Paulo S.A. } \\
\hline 1983 & Alterou razão social para Banco Noroeste S.A. \\
\hline 1997 & Incorporou-se ao Banco Santander Noroeste S.A. \\
\hline 1999 & Incorporou-se ao Banco Santander Brasil S.A. \\
\hline \multicolumn{2}{|c|}{ Banco da Província do Rio Grande do Sul S.A. } \\
\hline 1972 & Fundiu se ao Banco Sul Brasileiro S.A. \\
\hline 1985 & Alterou razão social para Banco Meridional do Brasil S.A \\
\hline 2000 & Incorporou-se ao Banco Santander S.A. \\
\hline 2000 & Alterou razão social para Banco Santander Meridional S.A. \\
\hline \multicolumn{2}{|c|}{ Banco do Pará S.A. } \\
\hline 1967 & Incorporou-se ao Banco do Estado de São Paulo S.A \\
\hline 1999 & Alterou razão social para Banco do Estado de São Paulo S.A. - Banespa \\
\hline \multicolumn{2}{|c|}{ Banco Nacional do Paraná e Santa Catarina S.A. } \\
\hline 1965 & Alterou razão social para Banco Nacional da Lavoura e Comércio S.A. \\
\hline 1965 & Incorporou-se ao Banco do Estado de São Paulo S.A. \\
\hline 1999 & Alterou razão social para Banco do Estado de São Paulo S.A Banespa \\
\hline \multicolumn{2}{|c|}{ Banco da Lavoura e Comércio do Estado de São Paulo S.A. } \\
\hline 1965 & Incorporou-se ao Banco Nacional do Paraná e Santa Catarina S.A. \\
\hline 1965 & Alterou razão social para Banco Nacional da Lavoura e Comércio S.A. \\
\hline 1965 & Incorporou-se ao Banco do Estado de São Paulo S.A. \\
\hline 1999 & Alterou razão social para Banco do Estado de São Paulo S.A. - Banespa \\
\hline \multicolumn{2}{|c|}{ Banco do Estado de São Paulo S.A. Banespa } \\
\hline & Adquirido pelo Banco Santander Brasil S.A. \\
\hline
\end{tabular}

Fonte: Febraban. 
Anexo 5:

DIVERSOS NEGÓCIOS ENTRE EMPRESAS (BRASIL E MUNDO) - 1990/2003

\begin{tabular}{|c|c|c|c|c|c|}
\hline EMPRESA & PAÍS & COMPRADOR & PAÍS & SETOR & ANO \\
\hline Wells & Brasil & ISS & Dinamarca & $\begin{array}{l}\text { Catering (cozinha } \\
\text { industrial) }\end{array}$ & 1990 \\
\hline $\begin{array}{l}\text { Fábrica Bangu (antiga "Progresso Industrial } \\
\text { do Brasil") }\end{array}$ & Brasil & Grupo Dona Isabel (Ricardo Haddad) & Brasil & Têxtil & 1990 \\
\hline Borg/Warner do Brasil Ind. e Comércio & Brasil & Sachs Automovie Ltda (Manesmann) & Alemanha & Autopeças & 1990 \\
\hline Cinzano & & Heublein & & Bebidas & 1990 \\
\hline Renault e Volvo & & associação para fabricar caminhões & & Automobilístico & 1990 \\
\hline R.J. Reynolds (operações no Brasil) & & Philip Morris & EUA & Fumo & 1990 \\
\hline Rádio Cidade FM (Grupo Jornal do Brasil) & Brasil & Rede Brasil Sul (RBS) & Brasil & $\begin{array}{c}\text { Meios de } \\
\text { comunicacão }\end{array}$ & 1990 \\
\hline MGM/UA Communications & EUA & Pathé & França & Estúdios de cinema & 1990 \\
\hline Rorer Group Inc. & EUA & Rhône Poulenc & França & Farmacêutico & 1990 \\
\hline Uniroyal Goodrich & EUA & Michelin & França & Pneus & 1990 \\
\hline IBM e Siemens & & $\begin{array}{l}\text { anúncio de formação de uma joint-venture para a } \\
\text { produção de chips }\end{array}$ & & & 1991 \\
\hline Usiminas & Brasil & CVRD, Nippon Usiminas, Previ, etc. & Brasil/Japão & Siderúrgico & 1991 \\
\hline Getoflex (Pirelli) & & British Tire and Rubber & & & 1992 \\
\hline Companhia Siderúrgica de Tubarão & Brasil & $\begin{array}{l}\text { Acesita, Usinor, Kawasaki, CVRD, Califórnia } \\
\text { Steel Industry }\end{array}$ & $\begin{array}{l}\text { Brasil/Japão/ } \\
\text { EUA }\end{array}$ & Siderúrgico & 1992 \\
\hline McCaw Cellular Communications & EUA & AT\&T (negócio fechado por US\$ 12,6 bilhões) & EUA & Telecomunicações & 1993 \\
\hline Companhia Siderúrgica Nacional-CSN & Brasil & Usiminas & & Siderúrgico & 1993 \\
\hline Nordeste & Brasil & Rio-Sul & Brasil & Aviação & 1994 \\
\hline Continental Bank & EUA & Bank of America & EUA & Financeiro & 1994 \\
\hline Banco Multiplic & Brasil & Banco Losango & Brasil & Financeiro & 1994 \\
\hline Cablevisión (49\%) & & Telmex & México & Telecomunicações & 1994 \\
\hline Atlantic & & Grupo Ipiranga & & Petrolífero & 1994 \\
\hline $\begin{array}{l}\text { Joint venture entre a Texas Instruments e a } \\
\text { Hitachi }\end{array}$ & & objetivo: fabricar semi-condutores nos EUA & & & 1994 \\
\hline TVA (Grupo Abril) & Brasil & $\begin{array}{l}\text { Chase Manhattan Bank (aquisição de 17\% do } \\
\text { controle) }\end{array}$ & & & \\
\hline Petroquímica União & Brasil & Union Carbide & EUA & Petroquímico & 1994 \\
\hline
\end{tabular}




\begin{tabular}{|c|c|c|c|c|c|}
\hline Celbrás & Brasil & Rhodia & França & Têxtil & 1994 \\
\hline Adria & Brasil & Quaker Oats & EUA & Alimentos & 1994 \\
\hline Continental 2001 & Brasil & Bosch/Siemens & Alemanha & Eletrodomésticos & 1994 \\
\hline Plus Vita & Brasil & Bunge Alimentos & & Alimentos & 1995 \\
\hline Laticínios Avaré & Brasil & Nabisco & EUA & Laticínios & 1995 \\
\hline Rede de TV ABC & EUA & Disney & EUA & Entretenimento & 1995 \\
\hline UJB Financial & EUA & $\begin{array}{l}\text { Summit Bancorporation (fusão de dois Financeiro } \\
\text { regionais) }\end{array}$ & EUA & Financeiro & 1995 \\
\hline Chemical & EUA & Chase Manhattan & EUA & Financeiro & 1995 \\
\hline First Chicago Corporation & EUA & $\begin{array}{l}\text { NBD Bancorp (a associação gerou nova entidade } \\
\text { bancária com capital de US\$ } 120 \text { bilhões, } 1 \text { dos } 10 \\
\text { maiores bancos dos EUA) }\end{array}$ & EUA & Financeiro & 1995 \\
\hline Bank South & EUA & $\begin{array}{l}\text { NationsBank ( } 3^{\mathrm{a}} \text { maior instituição financeira } \\
\text { dos EUA) }\end{array}$ & EUA & Financeiro & 1995 \\
\hline Filtros de Papel Jovita & Brasil & Melitta & Alemanha & & 1995 \\
\hline Baltimore Gas + Potomac Electric & EUA & $\begin{array}{l}\text { Duas das maiores empresas do setor anunciaram fusão } \\
\text { que envolve a soma de US\$2,9 bilhões }\end{array}$ & & Elétrico & 1995 \\
\hline $\begin{array}{l}\text { Babcock International ( } 75 \% \text { da empresa } \\
\text { de eletricidade) }\end{array}$ & Reino Unido & Mitsui & Japão & Elétrico & 1995 \\
\hline Campineira & Brasil & Danone & França & Alimentos & 1995 \\
\hline Petroquímica Bahia Blanca & & Dow Chemical/YPF S.A. & $\begin{array}{c}\text { EUA/ } \\
\text { Argentina }\end{array}$ & Petroquímico & 1995 \\
\hline Ciferal & Brasil & & & $\begin{array}{l}\text { Carrocerias de } \\
\text { ônibus }\end{array}$ & 1995 \\
\hline Lacta & Brasil & Philip Morris & EUA & Alimentos & 1995 \\
\hline Lacta (Philip Morris) & & Kraft Suchard (por US\$ 245 milhões) & & Alimentos & 1996 \\
\hline Rede de Lanchonetes Big Burguer & & Bob's & & Lanchonetes & 1996 \\
\hline $\begin{array}{l}\text { BCD União de Editoras S/A. (Bertrand Brasil, } \\
\text { Civilização Brasileira e Difel) }\end{array}$ & Brasil & Editora Record & Brasil & Editorial & 1996 \\
\hline Banco Nacional, & Brasil & Unibanco & Brasil & Financeiro & 1996 \\
\hline Excel & Brasil & Econômico & & Financeiro & 1996 \\
\hline Banorte & Brasil & Bandeirantes & & Financeiro & 1996 \\
\hline Mercantil & Brasil & Rural & & Financeiro & 1996 \\
\hline Antônio de Queiroz & Brasil & United & & & 1996 \\
\hline Martinelli & Brasil & Pontual & & & 1996 \\
\hline Kolynos & & Colgate-Palmolive & & & 1996 \\
\hline
\end{tabular}




\begin{tabular}{|c|c|c|c|c|c|}
\hline Siderúrgica Pains & & Gerdau & Brasil & Siderúrgico & 1996 \\
\hline Light & Brasil & $\begin{array}{l}\text { Electricité de France, AES Corporation, Reliant } \\
\text { Energy e CSN }\end{array}$ & $\begin{array}{c}\text { França/EUA/ } \\
\text { Brasil }\end{array}$ & Elétrico & 1996 \\
\hline Tintas Coral & Brasil & ICI & Reino Unido & $\begin{array}{c}\text { Química e } \\
\text { petroquímica }\end{array}$ & 1996 \\
\hline Bethânia & Brasil & Parmalat & Itália & Alimentos & 1996 \\
\hline Naturalat (Leitesol) & Brasil & Mastellone (La Serenísima) & Itália & Alimentos & 1996 \\
\hline Support Produtos Nutricionais & Brasil & Royal Numico & Holanda & Alimentos & 1996 \\
\hline Laticínios CGCL (atual Elege Alimentos) & Brasil & Grupo Avipal (por R\$178 milhões) & Brasil & Alimentos & 1996 \\
\hline Refrigeração Paraná & Brasil & Electrolux & Suécia & Eletrodomésticos & 1996 \\
\hline Metal Leve & Brasil & Mahle/Cofap & $\begin{array}{l}\text { Alemanha/Bra } \\
\text { sil }\end{array}$ & Autopeças & 1996 \\
\hline Kenko do Brasil & & Kimberly-Clark & EUA & Higiene & 1996 \\
\hline Cia. Eletrônica Celma & Brasil & General Eletric & EUA & Aviação & 1996 \\
\hline Paulista Seguros & Brasil & Liberty Mutual & EUA & Seguros & 1996 \\
\hline Bompreço & Brasil & Royal Ahold & Holanda & Supermercados & 1996 \\
\hline Dako & Brasil & General Eletric & EUA & Eletrodomésticos & 1996 \\
\hline GNPP Previdência & & Grupo Rural (aquisição de 51\%) & & Seguros & 1997 \\
\hline GNPP Previdência & & Grupo Séculos (aquisição de 49\%) & & Seguros & 1997 \\
\hline Aetna $(49 \%)$ & & Sul América (51\%) [fazem joint venture] & & Seguros & 1997 \\
\hline Grupo Sudameris & & Generali do Brasil [fazem joint venture] & & Seguros & 1997 \\
\hline Excel Econômico & & $\begin{array}{l}\text { Cigna International [azem joint venture }(50 \% \\
\text { cada)] }\end{array}$ & & Seguros & 1997 \\
\hline Bamerindus Companhia de Seguros & Brasil & HSBC & Reino Unido & Seguros & 1997 \\
\hline Seguradora Oceânica & & Bozano, Simonsen & & Seguros & 1997 \\
\hline Indiana Cia. de Seguros & & Bradesco Seguros (aquisição de 51\%) & Brasil & Seguros & 1997 \\
\hline Hannover Paulista Seguros & & Euro-Hannover Holding (aquisição de 50\%) & & Seguros & 1997 \\
\hline Concórdia Seguros & & Mitsui Marine \& Kyoei Fire Seguros & & Seguros & 1997 \\
\hline com Unibanco & & $\begin{array}{l}\text { AIG Consumer Finance Group [fazem joint } \\
\text { venture] }\end{array}$ & & Seguros & 1997 \\
\hline Amico & & Excel Econômico & & Seguros & 1997 \\
\hline Icatu Hartford & & ITT Hartford (aquisição de 25\%) & & Seguros & 1997 \\
\hline Prudential Insurance & & Bradesco Seguros [fazem joint venture ( $50 \%$ cada)] & & Seguros & 1997 \\
\hline União de Seguros & & Bradesco Seguros (aquisição de 71,5\%) & & Seguros & 1997 \\
\hline $\begin{array}{l}\text { Palmeiron S.A. Indústrias Alimentícias (grupo } \\
\text { Bompreço, de PE) }\end{array}$ & Brasil & Arisco (por R\$ 35 milhões) & Brsil & Alimentos & 1997 \\
\hline
\end{tabular}




\begin{tabular}{|c|c|c|c|c|c|}
\hline Laboratório Carlo Erba & Brasil & Searle/Grupo Monsanto & EUA & $\begin{array}{c}\text { Químico- } \\
\text { farmacêutico }\end{array}$ & 1997 \\
\hline Banco Geral do Comércio (Camargo Corrêa) & Brasil & Banco Santander & Espanha & Financeiro & 1997 \\
\hline Hughes Eletronics & & Raytheon & EUA & Eletrônico & 1997 \\
\hline Morningstar Group Inc. & EUA & Suiza Foods Corp. & EUA & Alimentos & 1997 \\
\hline Ault Foods Ltd. & Canadá & Parmalat & Itália & Alimentos & 1997 \\
\hline Etti & Brasil & Parmalat & Itália & Alimentos & 1997 \\
\hline Usina São Geraldo & Brasil & Usina Santa Elisa & Brasil & Alimentos & 1997 \\
\hline Duracell & & Gillette & & & 1997 \\
\hline Banco Noroeste (família Cochrane Simonsen) & Brasil & Banco Santander & Espanha & Financeiro & 1997 \\
\hline Banco Multiplic (Ronaldo Cezar Coelho) & Brasil & Lloyds Bank & Reino Unido & Financeiro & 1997 \\
\hline Morgan Stanley & EUA & Dean Witter Discover \& Co. & & Corretoras de títulos & 1997 \\
\hline Rede Unimar (Banco Garantia) & Brasil & Paes Mendonça + Royal Ahold & $\begin{array}{c}\text { Brasil/ } \\
\text { Holanda }\end{array}$ & Supermercados & 1997 \\
\hline Transportadora Translor & Brasil & Ryder Systems & EUA & Transportes & 1997 \\
\hline $\begin{array}{l}\text { Dynamis Energética (proprietária de } 51,42 \% \text { da } \\
\text { Usina Hidrelétrica de Serra da Mesa/Rio Tocantins } \\
\text { - GO) }\end{array}$ & & $\begin{array}{l}\text { Consórcio VBC (Camargo Corrêa, Votorantim } \\
\text { Energia e Bradesco) }\end{array}$ & Brasil & Energia & 1997 \\
\hline Arno & Brasil & SEB (proprietária da Rowenta e T-Fal & França & Eletrodomésticos & 1997 \\
\hline ABC Roma (a participação da Globopar) & & $\begin{array}{l}\text { Arab Banking Corp., tornando-se o único prop. } \\
\text { do ABC Roma }\end{array}$ & EUA & Financeiro & 1997 \\
\hline $\begin{array}{l}\text { CAEMI (40\% de ações ordinárias e } 40 \% \\
\text { preferenciais) }\end{array}$ & Brasil & Mitsuy and Co. Ltd. & Japão & & 1997 \\
\hline TAM (aproximadamente $24 \%$ das ações) & Brasil & $\begin{array}{l}\text { Fundos administrados pelo Banco Garantia e } \\
\text { BEA Capital }\end{array}$ & Brasil & Aviação & 1997 \\
\hline $\begin{array}{lccc}\text { COFAP } \quad(11 \% & \text { de } & \text { ações } & \text { ordinárias } \\
\text { pertencentes a Abraham Kasinski }) & \end{array}$ & Brasil & Mahle & Alemanha & Autopeças & 1997 \\
\hline Sé Supermercados & Brasil & Banco Garantia & Brasil & Supermercados & 1997 \\
\hline Cia. Vale do Rio Doce -CVRD & Brasil & Consórcio Brasil/CSN & Brasil & Mineração & 1997 \\
\hline CEMIG (1/3 do capital) & Brasil & Southern Eletric & & Energia & 1997 \\
\hline Unilever & & ICI & & Químico & 1997 \\
\hline $\begin{array}{l}\text { ICI (os negócios mundiais de dióxido de } \\
\text { titânio e de poliéster) }\end{array}$ & & Dupont & & & 1997 \\
\hline $\begin{array}{l}\text { COFAP ( } 40 \% \text { da empresa de Leon e Nelson } \\
\text { Kasinski, sobrinhos de Abraham Kasinski) }\end{array}$ & Brasil & Magnetti Marelli/Fiat & Itália & Autopeças & 1997 \\
\hline Swiss Bank Corporation & Suiça & União de Bancos Suíços & Suíça & Financeiro & 1997 \\
\hline Banco Meridional & Brasil & Banco Bozano, Simonsen & Brasil & Financeiro & 1997 \\
\hline Cia. Real de Distribuição (CRD) & & SONAE & Portugal & Supermercados & 1997 \\
\hline
\end{tabular}




\begin{tabular}{|c|c|c|c|c|c|}
\hline Banerj & Brasil & Banco Itaú & Brasil & Financeiro & 1997 \\
\hline ITAP (divisão de embalagens) & & Dixie Toga & & Embalagens & 1997 \\
\hline Mesbla & Brasil & Mappin & Brasil & $\begin{array}{c}\text { Lojas de } \\
\text { Departamentos }\end{array}$ & 1997 \\
\hline Cia. Elétrica da Bahia & Brasil & $\begin{array}{l}\text { Consórcio Guaraniana/Iderdrola e Previ-Banco } \\
\text { do Brasil }\end{array}$ & $\begin{array}{l}\text { Espanha e } \\
\text { Brasil }\end{array}$ & Energia & 1997 \\
\hline Apple (ações) & EUA & Microsoft & EUA & Informática & 1997 \\
\hline $\begin{array}{l}\text { Banco de Crédito Real de Minas Gerais } \\
\text { (Credireal) }\end{array}$ & Brasil & Banco de Crédito Nacional - BCN & Brasil & Financeiro & 1997 \\
\hline Estaleiro Verolme & Brasil & Setal Engenharia & & Estaleiros & 1997 \\
\hline Unibanco Seguros (40\% de ações ordinárias) & Brasil & AIG (American International Group) & & Seguros & 1997 \\
\hline Ceval & Brasil & Bunge Alimentos (por US\$ 201 milhões) & & Alimentos & 1997 \\
\hline $\begin{array}{l}\text { Construtora Adolpho Lindenberg }(79,34 \% \text { das } \\
\text { ações ordinárias e controle) }\end{array}$ & Brasil & ALMA (Samir Dichy) & & Imobiliário & 1997 \\
\hline Salomon Brothers & EUA & Sanford Weill & EUA & Financeiro & 1997 \\
\hline Thermo King & & Ingersoll-Rand & & $\begin{array}{l}\text { Transportes } \\
\text { refrigerados }\end{array}$ & 1997 \\
\hline Compuserve & Brasil ? & WorldCom/American On Line & EUA & $\begin{array}{c}\text { Informação on } \\
\text { line/internet }\end{array}$ & 1997 \\
\hline Olivetti (49\% das ações) & & Mannesmann & Alemanha & & 1997 \\
\hline Brasmotor (Brastemp) [parte do Bradesco] & Brasil & Whirlpool & França & Eletrodomésticos & 1997 \\
\hline Banco Boavista (família Paula Machado) & Brasil & $\begin{array}{l}\text { Banco de Investimentos Inter-Atlântico/Grupo Espírito } \\
\text { Santo, Grupo Monteiro Aranha e Banco Crédit } \\
\text { Agricole }\end{array}$ & $($ Brasil/...) & Financeiro & 1997 \\
\hline Banco Fenícia (51\%) & Brasil & AIG/American International Group & & Financeiro & 1997 \\
\hline Zurich Insurance & & BAT (British American Tobacco) & Reino Unido & & 1997 \\
\hline GMG Brands & & Guinness & Reino Unido & Bebidas & 1997 \\
\hline $\begin{array}{l}\text { Ernst \& Young + KPMG (fusão de duas } \\
\text { consultorias de fusão e aquisição de } \\
\text { empresas) }\end{array}$ & EUA & & & $\begin{array}{l}\text { Auditoria e } \\
\text { contabilidade }\end{array}$ & 1997 \\
\hline ITT & & Starwood Lodging Trust & & Hoteleiro & 1997 \\
\hline Freios Varga & Brasil & Grupo Lucas Varity & Reino Unido & Autopeças & 1997 \\
\hline Kibon (Philip Morris) & & Gessy Lever & $\begin{array}{l}\text { R. Unido } \\
\text { /Holanda }\end{array}$ & Alimentos & 1997 \\
\hline Bamerindus & Brasil & HSBC & Reino Unido & Financeiro & 1997 \\
\hline Brascan ( $80 \%$ do capital total) & Brasil & Mellon Bank & & Financeiro & 1997 \\
\hline IAP & Brasil & Serrana S.A. & Brasil & & 1997 \\
\hline Agroceres & Brasil & Monsanto do Brasil & EUA & Alimentos & 1997 \\
\hline
\end{tabular}




\begin{tabular}{|c|c|c|c|c|c|}
\hline BCN e Credireal & Brasil & Bradesco & Brasil & Financeiro & 1997 \\
\hline Centrais Elétricas Matogrossense (Cemat) & Brasil & Grupo Rede/Vale, Paranapanema e Inepar & Brasil & Energia & 1997 \\
\hline Krupp & Alemanha & Thyssen & Alemanha & $\begin{array}{l}\text { Engenharia e } \\
\text { siderurgia }\end{array}$ & 1997 \\
\hline MCI Comunications & EUA & WorldCom & EUA & Comunicações & 1997 \\
\hline Westinghouse (setor de energia) & & Siemens & Alemanha & Energia & 1997 \\
\hline AGF & & Allianz & Alemanha & Seguros & 1997 \\
\hline Banco Graphus & Brasil & Banco Robert Fleming & Brasil & Financeiro & 1997 \\
\hline Quartzolit & Brasil & Saint Cobain & França & Argamassas & 1997 \\
\hline Dedini S.A. Siderúrgica & Brasil & Cia. Siderúrgica Belgo-Mineira & & Siderurgia & 1997 \\
\hline Energipe (Empresa Energética de Sergipe) & Brasil & Cataguazes-Leopoldina (Ivan Botelho) & Brasil & Energia & 1997 \\
\hline Vega Engenharia Ambiental & Brasil & Sita & França & Serviços Públicos & 1997 \\
\hline Gevisa S.A. Locomotivas & Brasil & General Eletric & EUA & & 1997 \\
\hline Supermercados Eldorado & Brasil & Rede Carrefour & França & Supermercados & 1997 \\
\hline $\mathrm{Ci}^{\mathrm{a}}$ Açucareira São Geraldo & Brasil & Usina Santa Elisa S.A. & & Sucroalcooleiro & 1998 \\
\hline Usina Diamante & Brasil & Cosan & & Sucroalcooleiro & 1998 \\
\hline Usina Adelaide & Brasil & Usina da Barra & & Sucroalcooleiro & 1998 \\
\hline Phytoervas & Brasil & Bristol-Myers Squibb & EUA & $\begin{array}{c}\text { Perfumaria e } \\
\text { cosméticos }\end{array}$ & 1998 \\
\hline $\begin{array}{l}\text { The Royal Bank of Canada + Bank of } \\
\text { Montreal }\end{array}$ & & & & Financeiro & 1998 \\
\hline AGF & (França & Allianz & Alemanha & Seguros & 1998 \\
\hline Banco Liberal (51\% do capital) & Brasil & Nations Bank & EUA & Financeiro & 1998 \\
\hline Inpacel e Bamerindus Agroflorestal & Brasil & Champion Papel e Celulose & & Papel & 1998 \\
\hline Corbeta e Czarina & & Ermeto & & Couro e calçados & 1998 \\
\hline Lucas Eletrical Systems do Brasil & & Cooper Industries & & Autopeças & 1998 \\
\hline $\begin{array}{l}\text { IMI (banco de investimentos) + San Paolo } \\
\text { (banco comercial) = fusão }\end{array}$ & Itália & Torna-se maior grupo bancário da Itália & & Financeiro & 1998 \\
\hline Havas & & Vivendi & França & Mídia & 1998 \\
\hline Hotéis Inter-Continental (grupo Saison) & Japão & BASS (Holliday Inn) & Inglaterra & Hoteleiro & 1998 \\
\hline Millos Comercial & Brasil & Grupo Pão de Açúcar & Brasil & Supermercados & 1998 \\
\hline $\begin{array}{l}\text { Batavo (Cooperativa Central de Laticínios do } \\
\text { Paraná) }\end{array}$ & Brasil & Parmalat & Itália & Laticínios & 1998 \\
\hline $\begin{array}{l}\text { Ficap (pertencia ao Grupo Arbi, de Daniel } \\
\text { Birman) }\end{array}$ & & Luksic (Metal Overseas, Chile) & & & 1998 \\
\hline $\begin{array}{l}\text { Ind. Alimentícia. Carlos de Brito S.A. (72\% } \\
\text { do capital da Fábrica Peixe) }\end{array}$ & Brasil & Bombril- Grupo Círio & $\begin{array}{c}\text { Itália/ } \\
\text { Luxemburgo }\end{array}$ & Alimentos & 1998 \\
\hline
\end{tabular}




\begin{tabular}{|c|c|c|c|c|c|}
\hline Banco América do Sul & Brasil & Sudameris (Banca Commerciale Italiana) & Itália & Financeiro & 1998 \\
\hline $\begin{array}{l}\text { Joint Venture entre AT\&T (EUA) e British } \\
\text { Telecom (Reino Unido) }\end{array}$ & & $\begin{array}{l}\text { nova companhia operará fora de seus países de } \\
\text { origem }\end{array}$ & & Telecomunicações & 1998 \\
\hline Degussa + Veba-Hulls (Alemanha) & & & & Química & 1998 \\
\hline Alumax & & Alcoa & EUA & Alumínio & 1998 \\
\hline Dow Jones Markets (ex-Telerate) & & Bridge Information Systems & EUA & & 1998 \\
\hline Random House & & Bertelsmann & Alemanha & Mídia & 1998 \\
\hline Mallory & Brasil & Moulinex & França & Eletrodomésticos & 1998 \\
\hline Banco Mappin e Financiadora Mappin & Brasil & $\begin{array}{lrrr}\text { GEC-United [associação entre } & \text { Casa } & \text { Anglo } \\
\text { Brasileira (Mappin) e GE Capital] } & & \\
\end{array}$ & & & 1998 \\
\hline Nakata & & Dana Corporation & & Autopeças & 1998 \\
\hline Rolls Royce (do grupo britânico Vickers) & Reino Unido & BMW & Alemanha & Automobilístico & 1998 \\
\hline $\begin{array}{l}\text { Philips + Osram formaram a CVL (a ser } \\
\text { instalada em Caçapava/SP) }\end{array}$ & & & & Bulbos de lâmpadas & 1998 \\
\hline Citicorp + Travelers & EUA & & & Financeiro & 1998 \\
\hline $\begin{array}{l}\text { Bank America + Nations Bank (formando o } 2^{\circ} \\
\text { maior banco norte-americano) }\end{array}$ & EUA & & & Financeiro & 1998 \\
\hline $\begin{array}{l}\text { First Chicago }+ \text { Banc One (tornando-se o } 5^{\circ} \\
\text { grupo financeiro norte-americano) }\end{array}$ & EUA & & & Financeiro & 1998 \\
\hline Courtaulds PLC & Inglaterra & Akzo Nobel & Alemanha & Química & 1998 \\
\hline 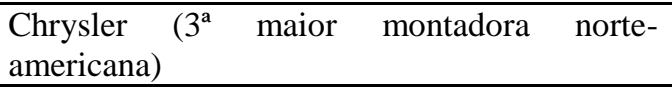 & EUA & Daimler-Benz & Alemanha & Automobilística & 1998 \\
\hline $\begin{array}{l}\text { Hotéis Caesar's Park (Grupo Aoki, Japão; dois } \\
\text { no Brasil e um na Argentina) }\end{array}$ & & Posadas (grupo mexicano da rede Fiesta) & & Hotéis & 1998 \\
\hline $\begin{array}{l}\text { Excel Econômico (Ezequiel Nasser; } 12^{\circ} \text { banco } \\
\text { brasileiro em ativos) }\end{array}$ & Brasil & Banco Bilbao Vizcaya (BBV) & Espanha & Financeiro & 1998 \\
\hline $\begin{array}{l}\text { Borlem [fabricante de rodas de aço e alumínio } \\
\text { ] }\end{array}$ & Brasil & Hayes Lemmerz & & Autopeças & 1998 \\
\hline $\begin{array}{l}\text { Panex havia adquirido a Penedo e a Rochedo } \\
\text { (1996) e a Clock (1992) }\end{array}$ & Brasil & Newell & EUA & $\begin{array}{l}\text { Utensílios } \\
\text { domésticos }\end{array}$ & 1998 \\
\hline Rede Barateiro & Brasil & Grupo Pão de Açúcar & Brasil & Supermercados & 1998 \\
\hline Acesita & Brasil & Usinor ( $4^{\circ}$ maior grupo no mundo $)$ & França & Siderúrgica & 1998 \\
\hline Polygram (75\% de participação da Philips) & & Seagram (setor de bebidas e entretenimento) & Canadá & $\begin{array}{l}\text { Gravadora e } \\
\text { produtora (cinema) }\end{array}$ & 1998 \\
\hline Ameritech & & $\begin{array}{l}\text { SBC Communications (tornando-se a maior no } \\
\text { setor) }\end{array}$ & EUA & Telefonia & 1998 \\
\hline
\end{tabular}




\begin{tabular}{|c|c|c|c|c|c|}
\hline $\begin{array}{l}\text { Editora Simon \& Schuster } \text { (pertencia a } \\
\text { Viacom) }\end{array}$ & & $\begin{array}{l}\text { Grupo Pearsom (tornou-se a maior editora de } \\
\text { livros didáticos do mundo) }\end{array}$ & & Livros didáticos & 1998 \\
\hline Frangosul & Brasil & Doux & França & Avicultura & 1998 \\
\hline Stora (Suécia) + Enso (Finlândia) & $\begin{array}{l}\text { Suécia/Finlân } \\
\text { dia }\end{array}$ & $\begin{array}{l}\text { Fusão que resultará no maior fabricante mundial } \\
\text { de papel }\end{array}$ & & $\begin{array}{l}\text { Reflorestamento, } \\
\text { papel e celulose }\end{array}$ & 1998 \\
\hline Wells Fargo + Norwest & EUA & $\begin{array}{l}\text { Fusão que resultará no } 7^{\circ} \text { maior banco norte- } \\
\text { americano }\end{array}$ & & Financeiro & 1998 \\
\hline Digital & & Compaq & & Computadores & 1998 \\
\hline $\begin{array}{l}\text { Tele-Communications ( } 2^{\mathrm{a}} \text { maior empresa de } \\
\text { TV a cabo) }\end{array}$ & EUA & AT\&T Corp & EUA & Telecomunicações & 1998 \\
\hline Cargill (área de sementes) & & Monsanto (por US\$1,4 bilhão) & & & 1998 \\
\hline DeKalb Genetics e Delta Pine Land & & Monsanto ( & & & 1998 \\
\hline Banco de Investimentos Garantia & Brasil & Crédit Suisse First Boston & & Financeiro & 1998 \\
\hline Cimento Maringá & Brasil & $\begin{array}{l}\text { Grupo Lafarge }\left(2^{\circ} \text { maior do mundo no setor, }\right. \\
\left.\text { torna-se o } 3^{\circ} \text { maior no Brasil }\right)\end{array}$ & & Cimento & 1998 \\
\hline $\begin{array}{l}\text { Cia. Riograndense de Telecomunicações - } \\
\text { CRT }\end{array}$ & Brasil & Consórcio Telefônica (Espanha) e RBS (Brasil) & & Telecomunicações & 1998 \\
\hline Supermercados Cândia (família Markakis) & Brasil & Rede Sonae (proprietária da rede gaúcha CRD) & Portugal & Supermercados & 1998 \\
\hline Ática Shopping & Brasil & Rede de livrarias Fnac & França & Livrarias & 1998 \\
\hline $\begin{array}{l}\text { Tropicana (pertencente ao Grupo Seagram's) } \\
\text { maior produtora norte-americana de suco }\end{array}$ & & Pepsi-Cola & & Bebidas & 1998 \\
\hline GTE & & Bell Atlantic & & Telecomunicações & 1998 \\
\hline Lamborghini & & Audi AG (Grupo Volkswagen) & & Automobilística & 1998 \\
\hline $\begin{array}{lllll}\text { Elektro (distribuidora } & \text { de } & \text { eletricidade } & \text { da } \\
\text { CESP) } & & & & \\
\end{array}$ & Brasil & Enrom & EUA & Energia & 1998 \\
\hline Golden Cross e Amico & & Cigna & EUA & Seguros (saúde) & 1998 \\
\hline $\begin{array}{l}\begin{array}{l}\text { Navegação Aliança (de } \\
\text { proprietário da Citrosuco) }\end{array} \\
\end{array}$ & & Hamburg Sud & Alemanha & & 1998 \\
\hline $\begin{array}{l}\text { Sistema Telebrás (dividido em } 12 \text { empresas } \\
\text { regionais) }\end{array}$ & Brasil & $\begin{array}{l}\text { Vários (Telesp ficou com a Telefônica de } \\
\text { Espanha). Valor aproximado: US\$ } 18,92 \text { bilhões }\end{array}$ & & Telecomunicações & 1998 \\
\hline Albertson's + American Stores & & $\begin{array}{l}\text { Fusão que resulta no maior supermercado norte- } \\
\text { americano }\end{array}$ & & Supermercados & 1998 \\
\hline SunAmerica (planos de aposentadoria) & & AIG & EUA & Seguros & 1998 \\
\hline Amoco Corp. & EUA & British Petroleum & Reino Unido & Petrolífero & 1998 \\
\hline Comptoirs Modernes & França & Carrefour & França & Supermercados & 1998 \\
\hline Lojas Americanas (23 unidades) & Brasil & Comptoirs Modernes & França & Supermercados & 1998 \\
\hline
\end{tabular}




\begin{tabular}{|c|c|c|c|c|c|}
\hline Sundown + Magna + CR & Brasil & $\begin{array}{l}\text { fundem-se na maior empresa do setor de } \\
\text { bicicletas no Brasil, (33\% do mercado) }\end{array}$ & & $\begin{array}{c}\text { Indústria de } \\
\text { bicicletas }\end{array}$ & 1998 \\
\hline SCI & Brasil & Equifax & EUA & $\begin{array}{l}\text { Serviços de } \\
\text { informação }\end{array}$ & 1998 \\
\hline $\begin{array}{l}\text { Castorama (França) + Kingfisher (Reino } \\
\text { Unido) }\end{array}$ & $\begin{array}{l}\text { França/Reino } \\
\text { Unido }\end{array}$ & Fusão que resulta na $3^{a}$ rede mundial no setor & & $\begin{array}{l}\text { Material para casa e } \\
\text { construção }\end{array}$ & 1998 \\
\hline BEMGE (Banco do Estado de Minas Gerais) & Brasil & Itaú & Brasil & Financeiro & 1998 \\
\hline Bandeirante & Brasil & EDP e CPFL (comprada pelo consórcio VBC) & Portugal & $\begin{array}{l}\text { distribuidora de } \\
\text { energia }\end{array}$ & 1998 \\
\hline Banco Omega & Brasil & UBS & Suíça & Financeiro & 1998 \\
\hline Barnes \& Noble (50\% da Divisão Internet) & & Bertelsmann & Alemanha & $\begin{array}{l}\text { Venda de livros } \\
\text { pela Internet }\end{array}$ & 1998 \\
\hline Carlsom & EUA & Thomas Cook & Inglaterra & Viagens & 1998 \\
\hline Café do Ponto e Café Seleto & Brasil & Grupo Sara Lee & EUA & Alimentos & 1998 \\
\hline Fred Meyer & & Kroger (maior rede de supermercados dos EUA) & EUA & Supermercados & 1998 \\
\hline Giant Food & & $\begin{array}{l}\text { Ahold Holandesa, passando para o } 5^{\circ} \text { lugar no } \\
\text { ranking de supermercados nos EUA. }\end{array}$ & Holanda & Supermercados & 1998 \\
\hline Kia e Asia (em leilão) & & Hyundai Motor & & Automobilística & 1998 \\
\hline Banco Pontual & Brasil & BCN/Bradesco & Brasil & Financeiro & 1998 \\
\hline Ciba + Clariant & & Fusão de duas grandes produtoras mundiais & & Química fina & 1998 \\
\hline Continental Grain & & Cargill & & $\begin{array}{l}\text { Commodities } \\
\text { agrícolas }\end{array}$ & 1998 \\
\hline Netscape & & America On Line & EUA & Provedor de internet & 1998 \\
\hline AMP & & Tyco International & & & 1998 \\
\hline Dover & EUA & Thyssen & Alemanha & $\begin{array}{c}\text { Elevadores e } \\
\text { escadas rolantes }\end{array}$ & 1998 \\
\hline Siebe + BTR (ambas da Inglaterra) & & $\begin{array}{l}\text { Fusão que resultará na maior empresa mundial do } \\
\text { setor }\end{array}$ & & $\begin{array}{l}\text { Controles e } \\
\text { automação }\end{array}$ & 1998 \\
\hline Banco Real & Brasil & ABN Amro Bank & Holanda & Financeiro & 1998 \\
\hline Fepasa & Brasil & Ferropasa (Grupo Itamarati) e CVRD & Brasil & Ferrovias & 1998 \\
\hline International Paper + Union Camp & & Fusão & & Papel & 1998 \\
\hline Unum + Provident & & Fusão & & Seguros & 1998 \\
\hline Banco do Estado de Pernambuco & Brasil & ABN Amro Bank & Holanda & Financeiro & 1998 \\
\hline Mercadorama (maior rede do PR) & Brasil & Sonae 1 & Portugal & Supermercados & 1998 \\
\hline Lojas Renner & Brasil & J.C. Penney & EUA & Comércio & 1998 \\
\hline Móbil & & Exxon & EUA & Petrolífero & 1998 \\
\hline Minorco S.A. (ativos de ouro) & & AngloGold S.A. (> produtora mundial de ouro) & África do Sul & Mineração & 1998 \\
\hline PacificCorp & EUA & ScottishPower Plc & Grã Bretanha & Energia Elétrica & 1998 \\
\hline
\end{tabular}




\begin{tabular}{|c|c|c|c|c|c|}
\hline Interlake & EUA & GKN Plc & Grã Bretanha & $\begin{array}{c}\text { Defesa, motores a } \\
\text { jato e autopeças }\end{array}$ & 1998 \\
\hline Neugebauer (grupo Fenícia/Arapuã) & Brasil & Parmalat (por US\$ 7 milhões) & Itália & Chocolates & 1998 \\
\hline Bankers Trust & EUA & Deutsche Bank (forma o maior banco do mundo) & & Financeiro & 1998 \\
\hline Rhône-Poulenc + Hoechst & & Fusão que cria a Aventis & & $\begin{array}{c}\text { Farmacêutico e } \\
\text { veterinário }\end{array}$ & 1998 \\
\hline Crédit Lyonnais & Bélgica & Deutsche Bank & & Financeiro & 1998 \\
\hline Zeneca Group + Astra & & Maior fusão do setor na Europa & & Farmacêutico & 1998 \\
\hline Viag (Alemanha) + Alusuisse (Suiça) & & Fusão & & Alumínio & 1998 \\
\hline Louis Trauth Dairy Inc. & EUA & Suiza Foods Corp. & EUA & Alimentos & 1998 \\
\hline Towerkop Dairy Ltd. & África do Sul & Parmalat & Itália & Alimentos & 1998 \\
\hline Laticínios Ivoti & Brasil & Milkaut & Argentina & Alimentos & 1998 \\
\hline Usina Sanagro & Brasil & Grupo José Pessoa & & Sucroalcooleiro & 1999 \\
\hline Usina Iracema & Brasil & Usina São Martinho & & Sucroalcooleiro & 1999 \\
\hline Fundo Trust \& Co. of The West & & Camil US\$ 21 milhões) & & Arroz & 1999 \\
\hline Granja Rezende & Brasil & Sadia (por US\$ 75 milhões) & Brasil & Avicultura & 1999 \\
\hline LG & Coréia & Philips Eletronics & & Eletrônico & 1999 \\
\hline MediaOne & EUA & AT\&T & EUA & Comunicações & 1999 \\
\hline Arisco & Brasil & Best Foods & EUA & Alimentos & 1999 \\
\hline Mococa S.A. Produtos Alimentícios & Brasil & Royal Numico & Holanda & Laticínios & 1999 \\
\hline Biscoitos Aymoré & Brasil & Danone & França & Alimentos & 1999 \\
\hline Fritex & & Visconti & & Alimentos & 1999 \\
\hline Frigorífico Chapecó & Brasil & Grupo Macri (por US\$213 milhões) & Argentina & Avicultura & 1999 \\
\hline Atlas & México & Sidenor & Espanha & Siderúrgico & 1999 \\
\hline Metamex & México & Sidenor & Espanha & Siderúrgico & 1999 \\
\hline Usina Iracema & Brasil & Usina São Martinho & Brasil & Sucroalcooleiro & 1999 \\
\hline Elf Aquitaine & França & Total Fina (por US\$ 54 bilhões) & França & Petrolífero & 1999 \\
\hline $\mathrm{AOL}$ & EUA & Time Warner & EUA & Comunicações & 2000 \\
\hline Pfizer com Warner-Lambert & & anuncio da fusão & & & 2000 \\
\hline Arremate.com & & Terra compra $30 \%$ & & & 2000 \\
\hline Telefônica + Deutsch Telecom & & possível fusão anunciada nesta data & & & 2000 \\
\hline Zipnet ( $3^{\circ}$ maior portal brasileiro) & Brasil & PT Multimedia, subsidiária da Portugal Telecom & Brasil/Portugal & Internet & 2000 \\
\hline Rede Reemberg (09 lojas) & Brasil & Grupo Pão de Açúcar & Brasil & Supermercados & 2000 \\
\hline Rede G. Pires (02 lojas) & Brasil & Grupo Pão de Açúcar & Brasil & Supermercados & 2000 \\
\hline Rede Nagumo (12 lojas) & Brasil & Grupo Pão de Açúcar & Brasil & Supermercados & 2000 \\
\hline Prenda S.A. & Brasil & Frigorífico Chapecó (Macri) & ARG & Frigorífico & 2000 \\
\hline
\end{tabular}




\begin{tabular}{|c|c|c|c|c|c|}
\hline Nelvana & & Corus Entertainment & & Entretenimento & 2000 \\
\hline U.S. Bancorp & EUA & Firstar & EUA & Financeiro & 2000 \\
\hline Paulista & Brasil & Danone & França & Alimentos & 2000 \\
\hline Pauli & Brasil & Danone & França & Alimentos & 2000 \\
\hline Fruti & Brasil & Danone & França & Alimentos & 2000 \\
\hline Dean Foods & EUA & Suiza Foods Corp. & EUA & Alimentos & 2000 \\
\hline Mother's & EUA & Parmalat & Itália & Alimentos & 2000 \\
\hline Keebler Foods & EUA & Kellog's & EUA & Alimentos & 2000 \\
\hline Batávia $(51 \%)$ & Brasil & Perdigão (por US\$ 20 milhões) & Brasil & Alimentos & 2000 \\
\hline AIG Seguros & & Unibanco & BRA & Seguros & 2000 \\
\hline Trevo Seguros & BRA & Unibanco & BRA & Seguros & 2000 \\
\hline Banco de Chile & $\mathrm{CHI}$ & Grupo Luksic (Quinenco S.A.) & & Bsncos & 2000 \\
\hline Bank of Scotland & ESC & Abbey National Plc & R.U. & Financeiro & 2000 \\
\hline Basf Pharma & ALE & Abbott Laboratories & EUA & Farmacêutico & 2000 \\
\hline Stella Barros Turismo & BRA & Volando.com (Citicorp) & EUA & Turismo & 2000 \\
\hline Aços Villares & Brasil & Sidenor & Espanha & Siderúrgico & 2000 \\
\hline Challenge Air Cargo & EUA & UPS - United Parcel & EUA & Logística & 2000 \\
\hline Comlasa & EUA & UPS - United Parcel & EUA & Logística & 2000 \\
\hline Samitri & & CVRD & Brasil & Mineração & 2000 \\
\hline Socoimex & & CVRD & Brasil & Mineração & 2000 \\
\hline Kronembourg (Danone) & França & Scottish \& Newcastle & Reino Unido & Bebidas & 2000 \\
\hline $\begin{array}{l}\text { Pearson (Reino Unido) e Bertelsman } \\
\text { (Alemanha) }\end{array}$ & & $\begin{array}{l}\text { Fusão das unidades de televisão para criar nova } \\
\text { emissora européia }\end{array}$ & & Televisão & 2000 \\
\hline Usina Rafard & Brasil & Grupo Cosan & & Sucroalcooleiro & 2000 \\
\hline Usina Amalia/Santa Rosa & Brasil & Usina da Pedra & & Sucroalcooleiro & 2000 \\
\hline Usina Benaalcool & Brasil & Grupo José Pessoa & & Sucroalcooleiro & 2000 \\
\hline Usina Delta & Brasil & Grupo Carlos Lyra & & Sucroalcooleiro & 2000 \\
\hline Usina Cresciumal & Brasil & Coinbra/Dreyfuss & & Sucroalcooleiro & 2000 \\
\hline Destileria Vale do Rio Turvo & Brasil & Silveira Barros/Jorge Toledo & & Sucroalcooleiro & 2000 \\
\hline Ipaussu & Brasil & Union des Sucreries Agricoles & & Sucroalcooleiro & 2000 \\
\hline Alcovale Destilaria & Brasil & Unialco S/A Açúcar e Álcool & & Sucroalcooleiro & 2001 \\
\hline Refinadora Catarinense & Brasil & Glencore & & Sucroalcooleiro & 2001 \\
\hline Açucareira da Serra & Brasil & Grupo Cosan & & Sucroalcooleiro & 2001 \\
\hline Usina Alcomira & Brasil & Grupo Márcio José Pavan & & Sucroalcooleiro & 2001 \\
\hline Univalem/Guanabara (50\%) & Brasil & FBA & & Sucroalcooleiro & 2001 \\
\hline Destileria Água Limpa & Brasil & Grupo Petribu & & Sucroalcooleiro & 2001 \\
\hline Açúcar Guarani & Brasil & Béghin-Say & & Sucroalcooleiro & 2001 \\
\hline
\end{tabular}




\begin{tabular}{|c|c|c|c|c|c|}
\hline Usina São José & Brasil & Grupo Antonio Farias & & Sucroalcooleiro & 2001 \\
\hline Usina Luciânia & Brasil & Coinbra-Dreyfuss & & Sucroalcooleiro & 2001 \\
\hline Usina Santo Antonio & Brasil & FBA & & Sucroalcooleiro & 2001 \\
\hline Batávia (49\% restantes)) & Brasil & Perdigão & Brasil & Alimentos & 2001 \\
\hline Petroquímica do Nordeste (Copene) & Brasil & Odebrecht e Mariani (criou a Brasken em 2002) & Brasil & Petroquímico & 2001 \\
\hline Portobello (SC) & Brasil & Glencore & Suiça & Refino de açucar & 2001 \\
\hline Banca Intesa SpA & Itália & UniCrédito Italiano SpA & Italia & Financeiro & 2001 \\
\hline Guararapes & Brasil & Coca-cola & EUA & Refrigerantes & 2001 \\
\hline US Airways Group Inc. & EUA & UAL Corporation (United Airlines) & EUA & Aviação & 2001 \\
\hline Blue Circle Industries & Inglaterra & Lafarge & França & Cimento & 2001 \\
\hline Vantec (Nissan) & Japão & $3 \mathrm{i}$ & & Logística & 2001 \\
\hline GIIC & Bahrain & CVRD & Brasil & Minério de Ferro & 2001 \\
\hline Web Trends & EUA & Net IQ & EUA & $\mathrm{TI}$ & 2001 \\
\hline Endesa & Espanha & Iberdrola & Espanha & Eletricidade & 2001 \\
\hline Fritz Companies & & UPS - United Parcel & EUA & Logística & 2001 \\
\hline Companhia das Pizzas & Brasil & Avipal & Brasil & Alimentos & 2001 \\
\hline Nutrir & Brasil & Kerry & Irlanda & Alimentos & 2001 \\
\hline Sibér & Brasil & Kerry & Irlanda & Alimentos & 2001 \\
\hline Visconti $(50 \%)$ & & Bauducco & & Alimentos & 2001 \\
\hline Visconti (divisão de chocolates) & & Hershey’s & EUA & Alimentos & 2001 \\
\hline TWA & & American Airlines & EUA & Aviação & 2001 \\
\hline VoiceStream Wireless Corp. & EUA & Deutsche Telekom AG (por US\$ 24,6 milhões) & Alemanha & Telecomunicações & 2001 \\
\hline Viag Interkom GmbH \& Co. & Alemanha & $\begin{array}{l}\text { British Telecommunications Plc (por US\$ 13,8 } \\
\text { milhões) }\end{array}$ & Reino Unido & Telecomunicações & 2001 \\
\hline Banamex & México & Citigroup (por US\$ 12,5 milhões) & EUA & Financeiro & 2001 \\
\hline Powertel Telekom AG & EUA & Deutsche Telekom (por US\$12,3 milhões) & Alemanha & Telecomunicações & 2001 \\
\hline Biliton Plc & Reino Unido & BHP (por US\$ 11,5 milhões) & Austrália & Mineração & 2001 \\
\hline Axa Financial Inc. & EUA & AXA Group (AXA-UAP) (por US\$ 11,2 milhões) & França & Seguros & 2001 \\
\hline De Beers & África do Sul & DB Investiments (por US\$ 11,1 milhões) & Reino Unido & Mineração & 2001 \\
\hline Ralston Purina Group & EUA & Nestlé (por US\$ 10,4 milhões) & Suíça & Alimentos & 2001 \\
\hline CIT Group Inc. & EUA & Tyco Intenational Ltd (por US\$ 10,2 milhões) & Bermudas & Eletrônica & 2001 \\
\hline AT\&T Wireless Group & EUA & NTT DoCoMo Inc (por US\$ 9,8 milhões) & Japão & Telecomunicações & 2001 \\
\hline Power Gen & Reino Unido & E. On AG (por US\$ 7,3 milhões) & Alemanha & Energia & 2001 \\
\hline Knoll AG (BASF AG) & Alemanha & Abbott Laboratories (por US\$ 6,9 milhões) & EUA & & 2001 \\
\hline GKN PLC-Support Services & Reino Unido & Brambles Industries (por US\$ 5,8 milhões) & Austrália & Autopeças & 2001 \\
\hline Harcourt General Inc. & EUA & Reed Elsevier Plc (por US\$ 5,6 milhões) & Reino Unido & $\begin{array}{l}\text { Serviços de } \\
\text { informação }\end{array}$ & 2001 \\
\hline
\end{tabular}




\begin{tabular}{|c|c|c|c|c|c|}
\hline Japan Telecom Co. Ltda. and J-Phone & Japão & Vodafone Group Inc (por US\$ 5,5 milhões) & Reino Unido & Telecomunicações & 2001 \\
\hline Lasmo Plc & Reino Unido & EniSpA (por US\$ 4,1 milhões) & Itália & Petróleo & 2001 \\
\hline BEG (GO) & Brasil & Itaú & Brasil & Financeiro & 2002 \\
\hline Banestado (PR) & Brasil & Itaú & Brasil & Financeiro & 2002 \\
\hline Banerj (RJ) & Brasil & Itaú & Brasil & Financeiro & 2002 \\
\hline Bemge (MG) & Brasil & Itaú & Brasil & Financeiro & 2002 \\
\hline Neugebauer (Parmalat) & & Florestal Alimentos & & Alimentos & 2002 \\
\hline Usina Bela Vista & Brasil & Usina Bazan & & Sucroalcooleiro & 2002 \\
\hline Guanabara & Brasil & Grupo Cosan & & Sucroalcooleiro & 2002 \\
\hline Usina Santa Cruz & Brasil & Grupo José Pessoa & & Sucroalcooleiro & 2002 \\
\hline Usina Maluf & Brasil & Dulcini & & Sucroalcooleiro & 2002 \\
\hline Usina Junqueira & Brasil & Grupo Cosan & & Sucroalcooleiro & 2002 \\
\hline Usina Gantus & Brasil & Grupo Toledo & & Sucroalcooleiro & 2002 \\
\hline Usina da Barra & Brasil & Grupo Cosan & & Sucroalcooleiro & 2002 \\
\hline Usina Alcoazul & Brasil & Grupo José Pessoa & & Sucroalcooleiro & 2002 \\
\hline Usina Quissaman & Brasil & Grupo José Pessoa & & Sucroalcooleiro & 2003 \\
\hline Wella & Alemanha & $\mathrm{P} \& \mathrm{G}$ & EUA & & 2003 \\
\hline Sudameris & & ABN Real & Holanda & Financeiro & 2003 \\
\hline
\end{tabular}

Fontes: várias edições de: Gazeta Mercantil; Folha de S. Paulo; O Estado de S. Paulo; Valor Econômico; Carta Capital; América Economia e CEPAL. 